\title{
Diastereoselective Diboration of Cyclic Alkenes: Application to the Synthesis of Aristeromycin
}

\author{
Alex J. Vendola ${ }^{1}$, Christophe Allais ${ }^{2}$, Anne-Marie Dechert Schmitt ${ }^{2}$, James Lee ${ }^{1}$, Robert A. \\ Singer ${ }^{2}$, and James P. Morken ${ }^{1 *}$ \\ ${ }^{1}$ Department of Chemistry, Merkert Chemistry Center, Boston College, \\ Chestnut Hill, Massachusetts 02467 \\ ${ }^{2}$ Pfizer Worldwide Research and Development, Eastern Point Road, Groton, Connecticut 06340, \\ United States
}

\section{Supporting Information Table of Contents}

General Information

Experimental Procedures.

I. Procedures for the preparation of $\operatorname{Pt}(d b a)_{3}$

II. Procedures for the preparation of cyclic alkenyl substrates

III. General procedure for the diboration of cyclic alkenyl substrates with Pt(dba) 3 (method 1)

IV. General procedure for the diboration of cyclic alkenyl substrates with $\mathrm{Pt} / \mathrm{C}$ (method 2).

V. Characterization of cyclic alkene diboration products and analysis of stereochemistry (method 1).

VI. Characterization of cyclic alkene diboration products (method 2).

VII. Procedures and characterization of diboronate functionalizations.

VIII. Procedures and characterization of compounds for the synthesis of aristeromycin

IX. Gram-scale reaction

References

Spectral Data

Crystallographic Data. S-85 


\section{General Information}

${ }^{1} \mathrm{H}$ NMR spectra were recorded on either a Varian Gemini-500 $(500 \mathrm{MHz})$ or Varian Gemini-600 (600 MHz) spectrometer. Chemical shifts were reported in ppm with the solvent resonance as the internal standard $\left(\mathrm{CDCl}_{3}: 7.26 \mathrm{ppm}\right)$. Data were reported as follows: chemical shift, integration, multiplicity $(\mathrm{s}=$ singlet, $\mathrm{d}=$ doublet, $\mathrm{t}=$ triplet, $\mathrm{q}=$ quartet, $\mathrm{p}=$ pentet, $\mathrm{m}=$ multiplet, $b r=$ broad), and coupling constants $(\mathrm{Hz}) .{ }^{13} \mathrm{C}$ NMR spectra were recorded on either a Varian Gemini-500 (125 MHz) or Varian Gemini-600 (150 MHz) spectrometer with complete proton decoupling. Chemical shifts were reported in ppm with the solvent resonance as the internal standard $\left(\mathrm{CDCl}_{3}: 77.16 \mathrm{ppm}\right) .{ }^{11} \mathrm{~B}$ NMR spectra were recorded on a Varian Gemini-500 (128 $\mathrm{MHz}$ ) spectrometer; chemical shifts were reported in ppm using $\mathrm{BF}_{3} \cdot \mathrm{Et}_{2} \mathrm{O}$ as the external standard $\left(\mathrm{BF}_{3} \cdot \mathrm{Et}_{2} \mathrm{O}: 0.0 \mathrm{ppm}\right)$. Infrared (IR) spectra were recorded on a Bruker alpha-P Spectrometer. Frequencies were reported in wavenumbers $\left(\mathrm{cm}^{-1}\right)$ as follows: strong (s), broad (br), medium (m), and weak (w). High-resolution mass spectrometry (DART+) was performed at the Mass Spectrometry Facility, Boston College, Chestnut Hill, MA. Thin layer chromatography (TLC) was performed on aluminum backed $200 \mu \mathrm{m}$ silica gel plates from Silicycle with F254nm indicator. Visualization was performed using ultraviolet light $(254 \mathrm{~nm})$, ceric ammonium molybdate (CAM), or potassium permanganate $\left(\mathrm{KMnO}_{4}\right)$.

Selected single crystals suitable for X-ray crystallographic analysis were used for structural determination. The X-ray intensity data were measured at 173(2) K (Oxford Cryostream 700) on a Bruker Kappa APEX Duo diffractometer system equipped with a sealed Mo-target X-ray tube $(\lambda=0.71073 \AA)$ and a high brightness $\mathrm{I} \mu \mathrm{S}$ copper source $(\lambda=1.54178 \AA)$, coupled with a PHOTON II detector. The crystals were mounted on a goniometer head with paratone oil. The detector was placed at a distance of 5.000 from the crystal. For each experiment, data collection strategy was determined by APEX software package and all frames were collected with a scan width of $0.75^{\circ}$ in $\omega$ and $\varphi$ with an exposure time of 5 or $10 \mathrm{~s} / \mathrm{frame}$.

The frames were integrated with the Bruker SAINT Software package using a narrowframe integration algorithm to a maximum $2 \theta$ angle of $56.54^{\circ}$ ( $0.75 \AA$ resolution) for Mo data and of $134^{\circ}(0.84 \AA$ resolution) for $\mathrm{Cu}$ data. The final cell constants are based upon the refinement of the XYZ-centroids of several thousand reflections above $20 \sigma(\mathrm{I})$. Analysis of the data showed negligible decay during data collection. Data were corrected for absorption effects using the empirical method (SADABS). The structures were solved and refined by full-matrix least squares procedures on $\left|\mathrm{F}^{2}\right|$ using the Bruker SHELXTL (version 6.12) software package. All hydrogen atoms were included in idealized positions for structure factor calculations except for those forming hydrogen bonds or on a chiral center. Anisotropic displacement parameters were assigned to all non-hydrogen atoms, except those disordered. Relevant crystallographic data are summarized in Table 1.

All reactions were conducted in oven- or flame-dried glassware, and were performed $\mathrm{w}$ unless further specified. Tetrahydrofuran (THF), diethyl ether $\left(\mathrm{Et}_{2} \mathrm{O}\right)$, dichloromethane $\left(\mathrm{CH}_{2} \mathrm{Cl}_{2}\right)$ and toluene were purified using Pure Solv MD-4 solvent purification system, from Innovative Technology, Inc., by passing the solvent through two activated alumina columns after purging with argon. Bis(pinacolato)diboron was purchased from Ark Pharmaceuticals, Combi-Blocks, and Oakwood Chemicals, and recrystallized in hexanes before use. All other reagents were purchased from Sigma-Aldrich, Alfa Aesar, Fisher Scientific, Oakwood Chemicals, Synthonix, CombiBlocks, TCI America, Acros Organics, or Astatech, and used without further purification unless 
noted. Additional samples of (cis)-4-((tert-butyldimethylsilyl)oxy)cyclopent-2-en-1ylacetate and Tert-butyl-1,4-dihydro-1,4-epiminonaphthalene-9-carboxylate were generously donated by Pfizer.

\section{Experimental Procedures}

\section{Procedures for the Preparation of Pt(dba) $)_{3}(\mathrm{~S}-1)$}

$\mathrm{Pt}(\mathrm{dba})_{3}$ was prepared according to a literature procedure with a slight modification. ${ }^{1}$ Sodium acetate $(2.11 \mathrm{~g}, 25.7 \mathrm{mmol}, 18.0$ equiv.), tetrabutylammonium chloride (1.19 g, 4.29 mmol, 3.0 equiv.) and trans, trans-dibenzylideneacetone (2.35 g, $10.0 \mathrm{mmol}, 7.0$ equiv.) were added to a $250 \mathrm{~mL}$ two-neck round bottom flask equipped with a stir bar and condenser. The solids were dissolved in methanol $(65 \mathrm{~mL})$ and heated to $70{ }^{\circ} \mathrm{C}$ until full dissolution. In a separate vial, potassium tetrachloroplatinate (593 mg, $1.43 \mathrm{mmol}, 1.0$ equiv.) was dissolved in water ( $4.00 \mathrm{~mL}$ ), heated gently with a heat gun for full dissolution and charged into the reaction flask. The reaction was heated to $70{ }^{\circ} \mathrm{C}$ for three hours. After allowing to cool to room temperature, the reaction was concentrated to approximately half the volume. The solids were then filtered using a fritted funnel and washed with copious amounts of acetone $(75 \mathrm{~mL})$ and water $(50 \mathrm{~mL})$, until no yellow benzylideneacetone was observed. The resulting solid was placed on high-vacuum for 24 hours to remove all methanol and water, to afford a dark brown solid ( $487 \mathrm{mg}$, 38\% yield). All spectral data was in accordance with the literature. ${ }^{1}$

\section{Procedures for Preparation of Cyclic Alkenyl Substrates}

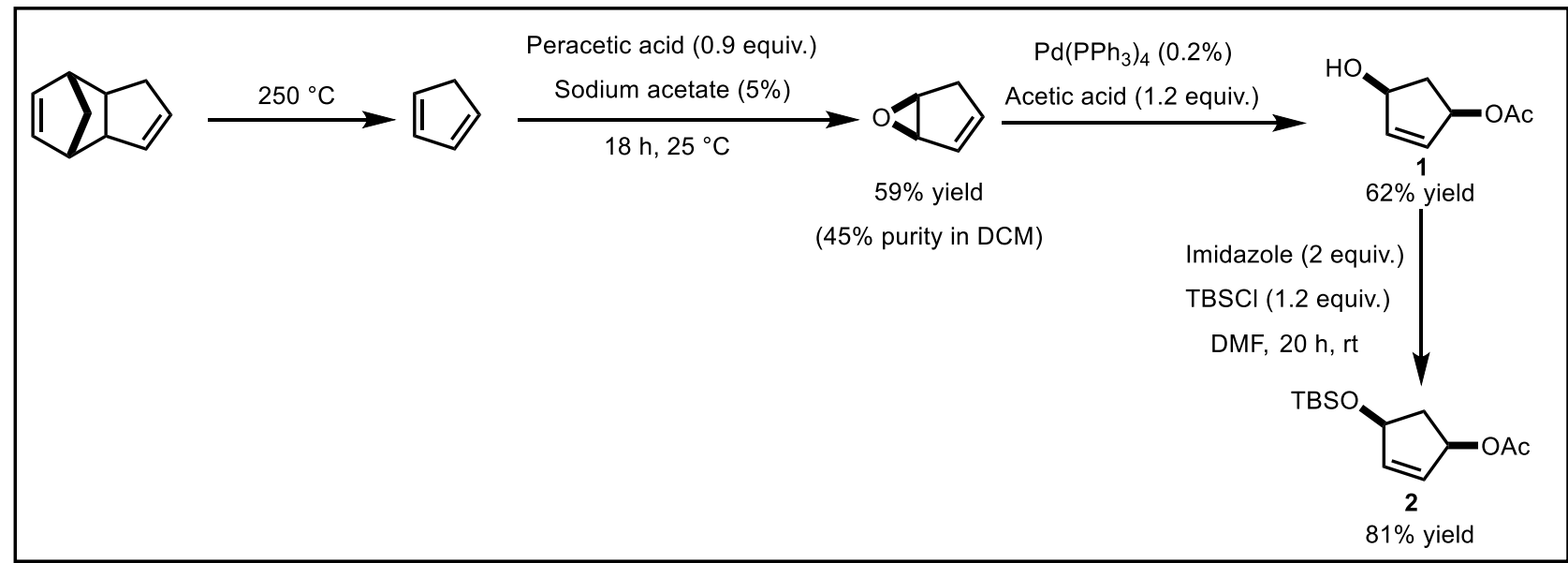

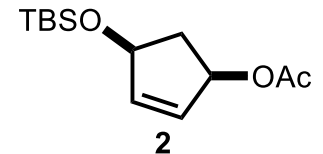

2
(Cis)-4-((tert-butyldimethylsilyl)oxy)cyclopent-2-en-1-yl acetate (2):

In an oven dried round bottom flask equipped with a stir bar was added dicyclopentadiene. The flask was equipped with a distillation apparatus containing a Vigreux column, a condenser, and a collection flask cooled at $78{ }^{\circ} \mathrm{C}$. The distillation flask was slowly heated to $250^{\circ} \mathrm{C}$ until the dicyclopentadiene began to boil. The first three milliliters in the collection flask were discarded, and then collection continued. The clear, colorless cyclopentadiene was confirmed to be pure via ${ }^{1} \mathrm{H}$ NMR and stored in a freezer. The epoxide, and then 1 were prepared using a known literature procedure. ${ }^{2}$ In a flame dried 250 
$\mathrm{mL}$ round bottom flask equipped with a stirbar was added dichloromethane $(135 \mathrm{~mL})$ followed by cyclopenta-1,3-diene (9.66 g, $146 \mathrm{mmol})$, followed by sodium carbonate $(34.1 \mathrm{~g}, 322 \mathrm{mmol}, 2.2$ equiv.) and sodium acetate $(599 \mathrm{mg}, 7.31 \mathrm{mmol}, 5.0 \%)$. The reaction was then cooled to $0{ }^{\circ} \mathrm{C}$ and peroxyacetic acid ( $10.0 \mathrm{~g}, 132 \mathrm{mmol}, 0.90$ equiv.) was then added dropwise over the course of one hour. The reaction was then sealed with a septum with a needle to act as a vent, warmed to room temperature, and allowed to stir for three hours. The mixture was then filtered with a fritted glass funnel and the solids were rinsed with dichloromethane $(20 \mathrm{~mL})$. The reaction was then concentrated under reduced pressure at low temperature $\left(15^{\circ} \mathrm{C}\right)$. The crude reaction mixture was then used without purification, and 6-oxabicyclo[3.1.0] hex-2-ene was determined via ${ }^{1} \mathrm{H}$ NMR to be $59 \%$ yield $(6.37 \mathrm{~g})$ as a solution of $45 \%$ purity in dichloromethane. All spectral data were in accordance with the literature. ${ }^{2}$

In the glovebox an oven dried $25 \mathrm{~mL}$ round bottom flask equipped with a stirbar was added tetrakis(triphenylphosphine)-palladium(0) $(31.5 \mathrm{mg}, 0.0273 \mathrm{mmol}, 0.2 \%)$, and tetrahydrofuran $(14.0 \mathrm{~mL})$ and then sealed with a septum and removed from the glovebox. The solution was then cooled to $0{ }^{\circ} \mathrm{C}$ and acetic acid ( $983 \mathrm{mg}, 16.4 \mathrm{mmol}, 1.2$ equiv.) was added. To the reaction flask was then added 6-oxabicyclo[3.1.0]hex-2-ene (2.49 g, $13.6 \mathrm{mmol}, 45 \%$ in dichloromethane) as a solution in tetrahydrofuran $(4.00 \mathrm{~mL})$ dropwise, and allowed to stir at $0{ }^{\circ} \mathrm{C}$ for one hour. The reaction was then concentrated under reduced pressure and passed through a silica gel plug with diethyl ether, and concentrated under reduced pressure. The crude mixture was then purified with the use of silica gel chromatography (40-70\% diethyl ether in pentane, stained in CAM) to afford a white solid. The solid was then recrystallized from 50:50 diethyl ether, pentane in a freezer to afford (4-hydroxycyclopent-2-en-1-yl) acetate 1, a clear, colorless solid (1.20 g, 62\% yield).

To an oven dried $25 \mathrm{~mL}$ round bottom flask equipped with a stirbar was added (4hydroxycyclopent-2-en-1-yl) acetate $(1.00 \mathrm{~g}, 7.03 \mathrm{mmol})$ followed by dimethylformanide (16.4 $\mathrm{mL})$. To the reaction was then added imidazole $(958 \mathrm{mg}, 14.1 \mathrm{mmol}, 2.0$ equiv.), followed by tertbutyl-chloro-dimethyl-silane (1.27 g, $8.44 \mathrm{mmol}, 1.20$ equiv.). The reaction flask was then sealed with a septum and allowed to stir at room temperature for 20 hours. The reaction was then quenched with the addition of saturated sodium bicarbonate $(20 \mathrm{~mL})$, and then the aqueous layer was washed three times with ethyl acetate $(3 \times 25 \mathrm{~mL})$. The organic layers were then combined, dried with $\mathrm{Na}_{2} \mathrm{SO}_{4}$, filtered, and concentrated under reduced pressure. The crude reaction mixture was then purified with the use of silica gel chromatography (5\% ethyl acetate in hexanes, stained in $\left.\mathrm{KMnO}_{4}\right)$, to afford a clear oil $(1.46 \mathrm{~g}, 81 \%$ yield). All spectra were in accordance with the literature. $^{2}$ 

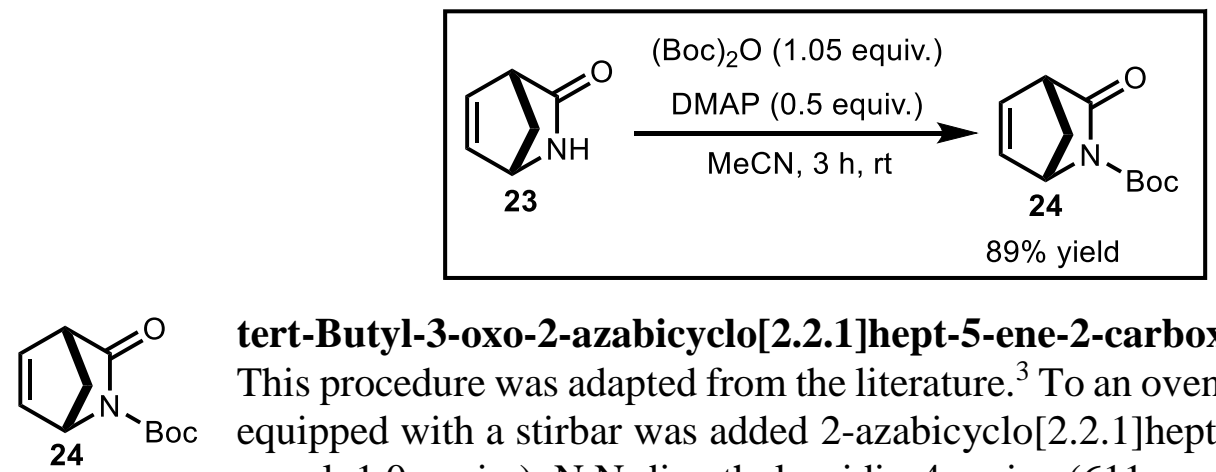

tert-Butyl-3-oxo-2-azabicyclo[2.2.1]hept-5-ene-2-carboxylate (24):

This procedure was adapted from the literature. ${ }^{3}$ To an oven dried round bottom flask equipped with a stirbar was added 2-azabicyclo[2.2.1]hept-5-en-3-one (1.09 g, 10.0 mmol, 1.0 equiv.), N,N-dimethylpyridin-4-amine (611 mg, $5.00 \mathrm{mmol}, 0.50$ equiv.), and acetonitrile $(10.0 \mathrm{~mL})$. Tert-butoxycarbonyl tert-butyl carbonate $(2.29 \mathrm{~g}, 10.5 \mathrm{mmol}, 1.05$ equiv.) was then added, and the reaction flask was sealed with a septum with a needle inserted to prevent a pressure increase of carbon dioxide. The reaction was then allowed to stir for three hours at room temperature. The reaction was then concentrated under reduced pressure. The crude reaction mixture was purified with the use of silica gel chromatography (10-20\% ethyl acetate in hexanes, stained in $\mathrm{KMnO}_{4}$ ) to afford a white solid (1.85 g, 89\% yield). All spectra were in accordance with the literature. ${ }^{3}$
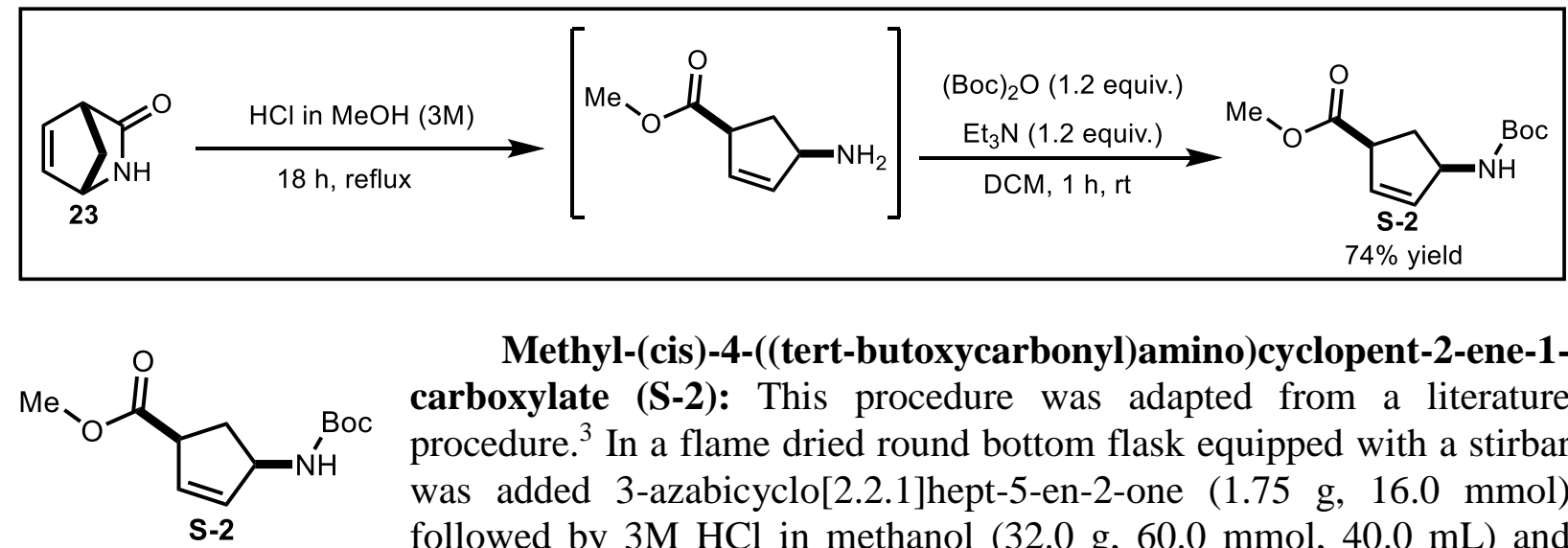

Methyl-(cis)-4-((tert-butoxycarbonyl)amino)cyclopent-2-ene-1carboxylate (S-2): This procedure was adapted from a literature procedure. ${ }^{3}$ In a flame dried round bottom flask equipped with a stirbar was added 3-azabicyclo[2.2.1]hept-5-en-2-one (1.75 g, $16.0 \mathrm{mmol})$ followed by $3 \mathrm{M} \mathrm{HCl}$ in methanol $(32.0 \mathrm{~g}, 60.0 \mathrm{mmol}, 40.0 \mathrm{~mL})$ and flushed with nitrogen, and then set to reflux for 18 hours. The reaction was then concentrated under reduced pressure, and the residue was dissolved in dichloromethane $(80.0 \mathrm{~mL})$ followed by the addition of $\mathrm{N}, \mathrm{N}$-diethylethanamine (1.94 g, $19.2 \mathrm{mmol}, 1.2$ equiv.) and tert-butoxycarbonyl tertbutyl carbonate $(4.19 \mathrm{~g}, 19.2 \mathrm{mmol}, 1.2$ equiv.) and stirred under room temperature for one hour. To the reaction was added $1 \mathrm{M} \mathrm{HCl}(80 \mathrm{~mL})$, and the layers were then separated. An additional aqueous extraction of the organic layer using water $(80 \mathrm{~mL})$ was then performed. The layers were then separated and to the organic layer was added $\mathrm{Na}_{2} \mathrm{SO}_{4}$, and the organic layer was filtered and concentrated under reduced pressure. The crude reaction mixture was then purified with the use of silica gel chromatography (10-20\% ethyl acetate in hexanes, stained in $\mathrm{KMnO}_{4}$ ) to afford a colorless liquid ( $2.88 \mathrm{~g}, 74 \%$ yield). All spectral data was in accordance with the literature. ${ }^{3}$ 

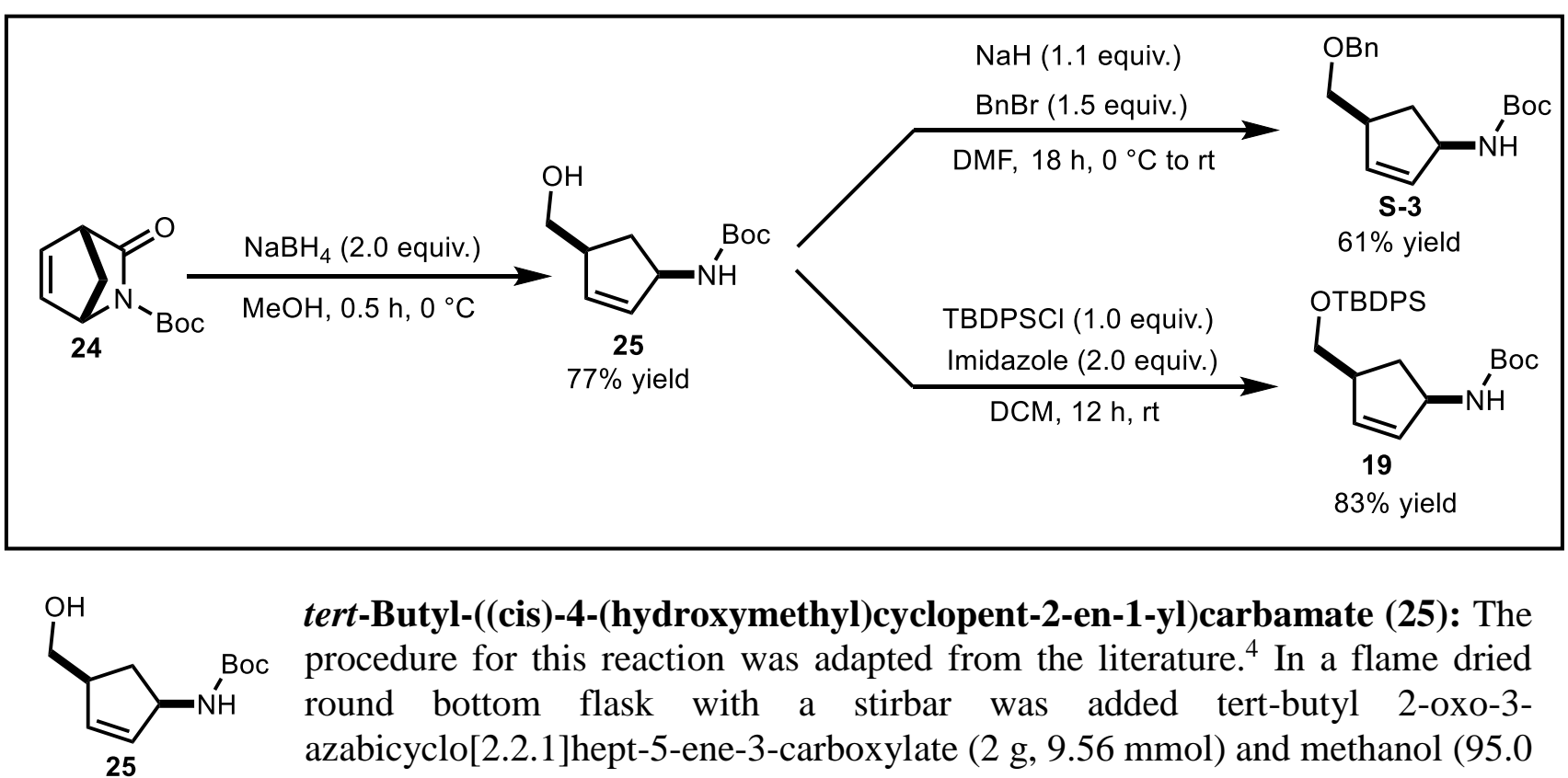

tert-Butyl-((cis)-4-(hydroxymethyl)cyclopent-2-en-1-yl)carbamate (25): The procedure for this reaction was adapted from the literature. ${ }^{4}$ In a flame dried round bottom flask with a stirbar was added tert-butyl 2-oxo-3azabicyclo[2.2.1] hept-5-ene-3-carboxylate $(2 \mathrm{~g}, 9.56 \mathrm{mmol})$ and methanol $(95.0$ $\mathrm{mL}$ ). At $0{ }^{\circ} \mathrm{C}$ was added sodium borohydride ( $723 \mathrm{mg}, 19.1 \mathrm{mmol}, 2$ equiv.). The reaction was then sealed with a septum, and a needle was inserted into the septum in order to equalize pressure, and the reaction was allowed to stir at $0{ }^{\circ} \mathrm{C}$ for thirty minutes. The mixture was then concentrated under reduced pressure, and then partitioned between ethyl acetate $(50 \mathrm{~mL})$ and water $(50 \mathrm{~mL})$. The layers were then separated and the aqueous layer was washed an additional two times with ethyl acetate $(2 \times 50 \mathrm{~mL})$. The combined organic layers were then dried with $\mathrm{Na}_{2} \mathrm{SO}_{4}$, filtered, and concentrated under reduced pressure. The crude alcohol was then purified with the use of silica gel chromatography ( $30 \%$ ethyl acetate in hexanes, stained in $\left.\mathrm{KMnO}_{4}\right)$ to yield the alcohol intermediate as a white solid (1.56 g, 77\% yield). All spectral data were in accordance with the literature. ${ }^{4}$

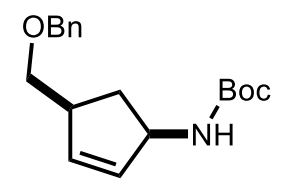

S-3
tert-Butyl ((cis)-4-((benzyloxy)methyl)cyclopent-2-en-1-yl)carbamate (S-3):

To a flame dried round bottom flask was added the alcohol intermediate 22 (350 $\mathrm{mg}, 1.64 \mathrm{mmol})$ and dimethylformanide $(2.30 \mathrm{~mL})$ and then cooled to $0{ }^{\circ} \mathrm{C}$. To the mixture was then added sodium hydride as a $60 \%$ dispersion in mineral oil (72.2 $\mathrm{mg}, 1.81 \mathrm{mmol}, 1.1$ equiv.) and allowed to stir at this temperature for 15 minutes. Benzyl bromide (351 mg, $2.05 \mathrm{mmol}, 1.25$ equiv.) was then added dropwise and allowed to stir at this temperature for 1.5 hours. The reaction was then warmed to room temperature and allowed to stir for an additional 18 hours. The reaction was then diluted with diethyl ether $(50 \mathrm{~mL})$ and quenched with saturated sodium bicarbonate $(50 \mathrm{~mL})$. The layers were then separated and the organic layer was washed an additional time with saturated sodium bicarbonate $(50 \mathrm{~mL})$ followed by brine $(50$ $\mathrm{mL}$ ). The organic layer was then dried using $\mathrm{Na}_{2} \mathrm{SO}_{4}$, filtered, and concentrated under reduced pressure. The residue was purified with the use of silica gel chromatography (5-10\% ethyl acetate in hexanes, stained in $\mathrm{KMnO}_{4}$ ) to yield a colorless oil (498 mg, 61\%). ${ }^{1} \mathrm{H} \mathrm{NMR}\left(500 \mathrm{MHz}, \mathrm{CDCl}_{3}\right)$ $\delta 7.38-7.24(\mathrm{~m}, 5 \mathrm{H}), 5.81(\mathrm{dt}, J=5.5,1.7 \mathrm{~Hz}, 1 \mathrm{H}), 5.75(\mathrm{dt}, J=5.5,1.7 \mathrm{~Hz}, 1 \mathrm{H}), 4.80(\mathrm{~s}(\mathrm{br}), 1 \mathrm{H})$, 4.69 (s (br), 1H), 4.54 (d, $J=12.1 \mathrm{~Hz}, 1 \mathrm{H}), 4.50$ (d, $J=12.1 \mathrm{~Hz}, 1 \mathrm{H}), 3.42$ (d, $J=5.0 \mathrm{~Hz}, 2 \mathrm{H})$, 2.87 (s (br), 1H), 2.47 (dt, $J=13.6,8.5 \mathrm{~Hz}, 1 \mathrm{H}), 1.42(\mathrm{~s}, 9 \mathrm{H}), 1.35(\mathrm{dt}, J=13.6,4.3 \mathrm{~Hz}, 1 \mathrm{H}) .{ }^{13} \mathrm{C}$ NMR $\left(126 \mathrm{MHz} \mathrm{CDCl}_{3}\right) \delta 155.0,138.0,134.3,132.8,128.2,127.44,127.39,78.5,73.0,72.9$, 
55.6, 44.7, 35.1, 28.3. IR (neat) vmax 3341 (br), 2975 (w), 2930 (w), 2859 (w), 1692 (s), 1495 (s), $1454(\mathrm{~m}), 1390(\mathrm{w}), 1364$ (s), 1332 (w), 1283 (w), 1241 (m), 1166 (s), 1072 (m), 1028 (w), $1001(\mathrm{~m}), 884(\mathrm{w}), 858(\mathrm{w}), 736(\mathrm{~s}), 596(\mathrm{br}) \mathrm{cm}^{-1}$. HRMS (DART+) m/z: [M+H] $]^{+}$Calcd for $\mathrm{C}_{18} \mathrm{H}_{26} \mathrm{NO}_{3}$ 304.1907; Found 304.1912.

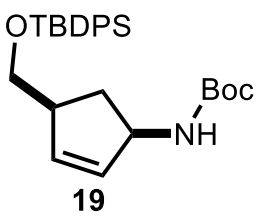

tert-Butyl-((cis)-4-(((tert-butyldiphenylsilyl)oxy)methyl)cyclopent-2-en-1yl)carbamate (19): To a flame dried round bottom flask equipped with a stirbar was added the alcohol intermediate $22(1.30 \mathrm{~g}, 6.10 \mathrm{mmol})$, followed by dichloromethane (12.8 mL). Imidazole (830 mg, $12.2 \mathrm{mmol}, 2.0$ equiv.) was then added, followed by tert-butylchlorodiphenylsilane (1.68 g, 1.0 equiv.). The reaction flask was then sealed with a septum, and allowed to stir at room temperature for 12 hours. The reaction was then quenched with water $(25 \mathrm{~mL})$, and then the organic and aqueous layers were separated. The aqueous layer was then washed an additional two times with dichloromethane $(2 \times 25 \mathrm{~mL})$, and the organic layers were then combined and washed with a cold solution of $1 \mathrm{~N} \mathrm{HCl}(25 \mathrm{~mL})$, and then an additional time with water $(25 \mathrm{~mL})$. The organic layer was then dried using $\mathrm{Na}_{2} \mathrm{SO}_{4}$, filtered, and concentrated under reduced pressure. The residue was then purified with the use of silica gel chromatography (20-30\% diethyl ether in pentane, stained in $\mathrm{KMnO}_{4}$ ) to yield a straw-yellow oil (2.29 g, 83\% yield). ${ }^{1} \mathrm{H}$ NMR $\left(500 \mathrm{MHz}, \mathrm{CDCl}_{3}\right) \delta 7.69(\mathrm{dq}, J=8.0,1.6 \mathrm{~Hz}, 4 \mathrm{H}), 7.49-7.34(\mathrm{~m}$, $6 \mathrm{H}), 5.83(\mathrm{~d}, J=4.6 \mathrm{~Hz}, 1 \mathrm{H}), 5.76(\mathrm{~d}, J=4.6 \mathrm{~Hz}, 1 \mathrm{H}), 4.80-4.67(\mathrm{~m}, 2 \mathrm{H}), 3.66-3.57(\mathrm{~m}, 2 \mathrm{H}), 2.84$ (tdd, $J=7.7,3.8,2.0 \mathrm{~Hz}, 1 \mathrm{H}), 2.49(\mathrm{dt}, J=16.9,8.4 \mathrm{~Hz}, 1 \mathrm{H}), 1.45(\mathrm{~s}, 9 \mathrm{H}), 1.37$ (d, $J=16.9 \mathrm{~Hz}$, $1 \mathrm{H}), 1.09(\mathrm{~d}, J=1.7 \mathrm{~Hz}, 9 \mathrm{H}) .{ }^{13} \mathrm{C} \mathrm{NMR}\left(126 \mathrm{MHz}, \mathrm{CDCl}_{3}\right) \delta 155.3,135.8,135.7,135.1,132.3$, 129.8, 127.8, 67.1, 56.2, 47.2, 34.9, 28.6, 27.1, 26.7, 19.4. IR (neat) vmax 3148 (br), 2931 (w), 2857 (w), 1711 (s), 1493 (m), 1428 (m), 1390 (s), 1365 (m), 1333 (s), 1243 (m), 1169 (s), 1111 (s), $1072(\mathrm{~m}), 997(\mathrm{~m}), 937(\mathrm{~s}), 859(\mathrm{~s}), 823(\mathrm{~m}), 737(\mathrm{~s}), 700(\mathrm{~s}), 607(\mathrm{~m}) \mathrm{cm}^{-1}$. HRMS (DART+) $\mathrm{m} / \mathrm{z}:[\mathrm{M}+\mathrm{H}]^{+}$Calcd for $\mathrm{C}_{27} \mathrm{H}_{38} \mathrm{NO}_{3} \mathrm{Si}$ 452.2616; Found 452.2674 .
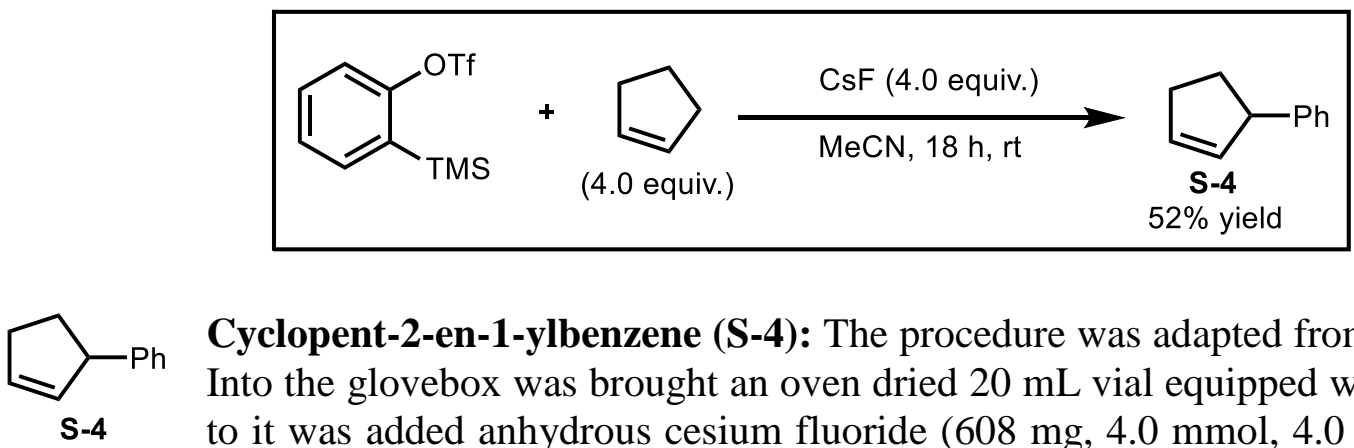

Cyclopent-2-en-1-ylbenzene (S-4): The procedure was adapted from the literature. ${ }^{5}$ Into the glovebox was brought an oven dried $20 \mathrm{~mL}$ vial equipped with a stirbar and to it was added anhydrous cesium fluoride (608 $\mathrm{mg}, 4.0 \mathrm{mmol}, 4.0$ equiv.), and the vial was then sealed with a septum and brought outside the glovebox. To the vial is then added acetonitrile $(14.6 \mathrm{~mL})$, followed by (2-trimethylsilylphenyl) trifluoromethanesulfonate (298 $\mathrm{mg}$, $1.0 \mathrm{mmol}$ ), and cyclopentene (272 $\mathrm{mg}, 4.0 \mathrm{mmol}, 4.0$ equiv.), and the reaction is allowed to stir at room temperature for 18 hours. To the reaction mixture is then added water $(10 \mathrm{~mL})$ and dichloromethane $(10 \mathrm{~mL})$. The layers are separated, and the aqueous layer is then washed an additional two times with dichloromethane $(2 \times 10 \mathrm{~mL})$. The organic layers are then combined, dried with $\mathrm{Na}_{2} \mathrm{SO}_{4}$, filtered, and concentrated under reduced pressure. The crude reaction mixture was purified with the use of silica gel chromatography (pentanes, stained in $\mathrm{KMnO}_{4}$ ) to yield a clear, colorless oil $\left(75.0 \mathrm{mg}, 52 \%\right.$ yield). All spectral data were in accordance with the literature. ${ }^{5}$ 

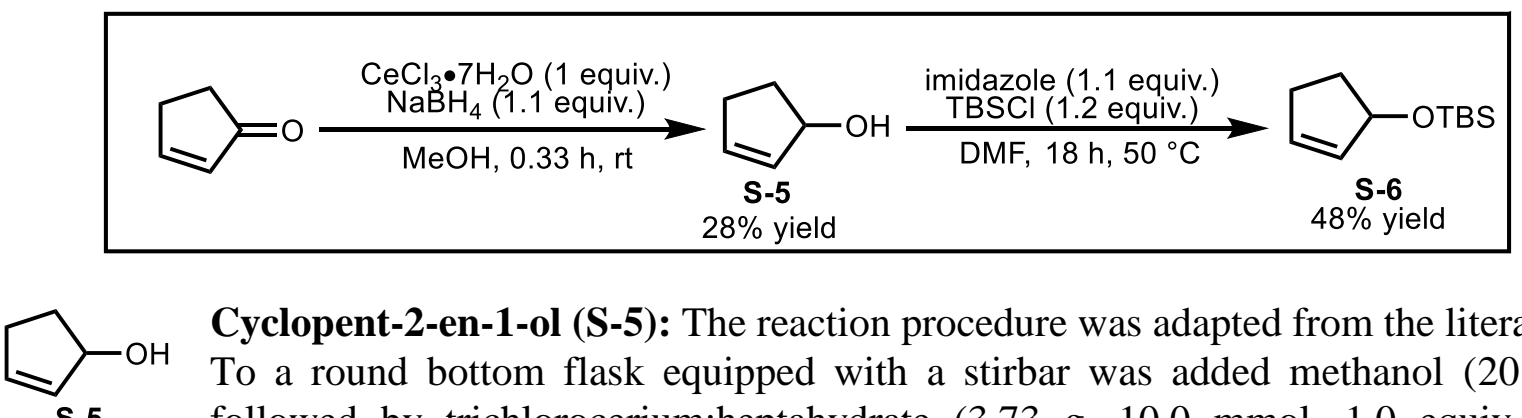

Cyclopent-2-en-1-ol (S-5): The reaction procedure was adapted from the literature. ${ }^{6}$ To a round bottom flask equipped with a stirbar was added methanol $(20 \mathrm{~mL})$, followed by trichlorocerium:heptahydrate $(3.73 \mathrm{~g}, 10.0 \mathrm{mmol}, 1.0$ equiv.) and cyclopent-2-en-1-one ( $821 \mathrm{mg}, 10.0 \mathrm{mmol})$, and then allowed to stir for five minutes at room temperature. Then, sodium borohydride $(416 \mathrm{mg}, 11 \mathrm{mmol}, 1.1$ equiv.) was added in portions very slowly. After completion, the reaction was allowed to stir for 15 minutes. The reaction is then quenched with water $(40 \mathrm{~mL})$. To the mixture is then added diethyl ether $(20 \mathrm{~mL})$, and the layers are separated. The aqueous layer was then washed an additional two times with diethyl ether $(2 \times 20$ $\mathrm{mL})$. The organic layers are then combined and washed an additional time with water $(20 \mathrm{ml})$, and the organic layer is collected, dried with $\mathrm{MgSO}_{4}$, filtered, and concentrated under reduced pressure. The crude reaction mixture wass then purified with the use of silica gel chromatography (30-40\% diethyl ether in pentanes, stained in $\mathrm{KMnO} 4)$, to afford a clear, colorless liquid (233 mg, $28 \%$ yield). The spectral data were in accordance with the literature. ${ }^{6}$

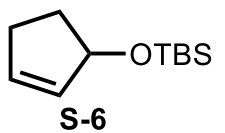

tert-Butyl(cyclopent-2-en-1-yloxy)dimethylsilane (S-6): The reaction procedure was adapted from the literature. ${ }^{7}$ To a flame dried round bottom flask equipped with a stirbar was added cyclopent-2-en-1-ol (233 $\mathrm{mg}, 2.77 \mathrm{mmol})$, followed by DMF (4.4 mL). To the reaction is then added imidazole (207 mg, $3.1 \mathrm{mmol}, 1.1$ equiv.), followed by tert-butyl-chloro-dimethyl-silane $(5.1 \mathrm{mg}, 3.32 \mathrm{mmol}, 1.2$ equiv.). The reaction is then sealed with a septum and flushed with nitrogen, and allowed to stir for 18 hours at $50{ }^{\circ} \mathrm{C}$. The reaction is then quenched with water, $20 \mathrm{~mL})$, and to it is added diethyl ether $(20 \mathrm{~mL})$. The layers are then separated, and the aqueous layer is washed an additional two times with diethyl ether $(2 \times 20 \mathrm{~mL})$. The organic layers are then collected and washed an additional time with water $(20 \mathrm{~mL})$, and the organic layer is collected, dried with $\mathrm{MgSO}_{4}$, filtered, and concentrated under reduced pressure. The crude reaction mixture was purified with the use of silica gel chromatography (0-10\% diethyl ether in pentanes, stained in $\mathrm{KMnO}_{4}$ ), to afford a clear oil (263 mg, $48 \%$ yield). All spectral data were in accordance with the literature. ${ }^{7}$
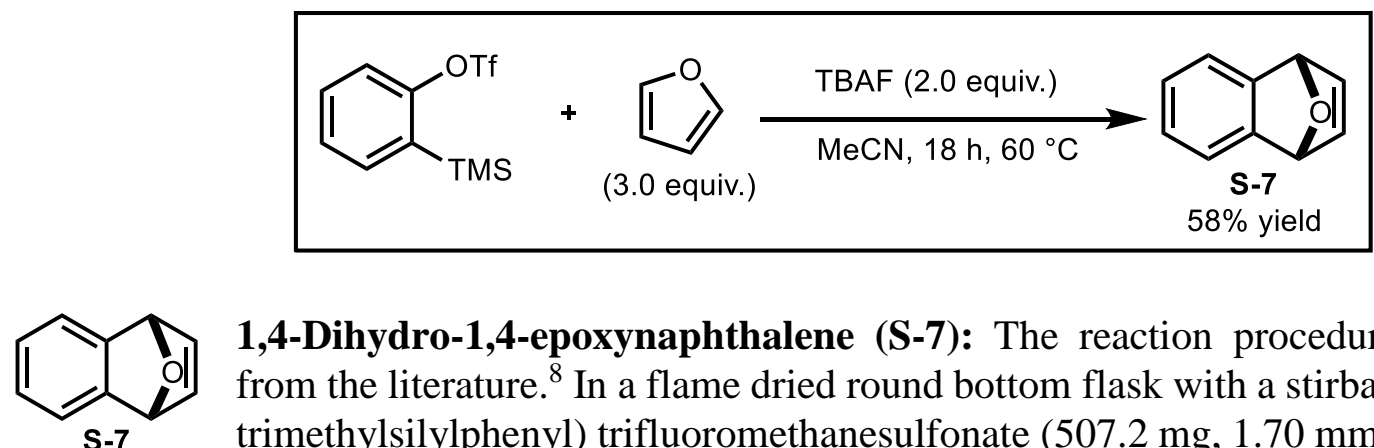

1,4-Dihydro-1,4-epoxynaphthalene (S-7): The reaction procedure was adapted from the literature. ${ }^{8}$ In a flame dried round bottom flask with a stirbar was added (2trimethylsilylphenyl) trifluoromethanesulfonate $(507.2 \mathrm{mg}, 1.70 \mathrm{mmol})$ followed by furan (347 mg, $5.10 \mathrm{mmol}, 3.0$ equiv.) and acetonitrile $(17.0 \mathrm{~mL})$. To the reaction mixture was added a $1 \mathrm{M}$ solution of tetrabutylammoniumfluoride in tetrahydrofuran $(889 \mathrm{mg}, 3.40$ 
mmol, $3.40 \mathrm{~mL}$ ) and was then heated for $60{ }^{\circ} \mathrm{C}$ for 18 hours. The reaction was then cooled to room temperature, and filtered through a plug of silica gel with ethyl acetate as the solvent. The eluent was then concentrated under reduced pressure. The reaction mixture was purified with the use of silica gel chromatography (0-15\% ethyl acetate in hexanes) to afford an off white solid (245 $\mathrm{mg}$, $58 \%$ yield). All spectral data were in accordance with the literature. ${ }^{8}$
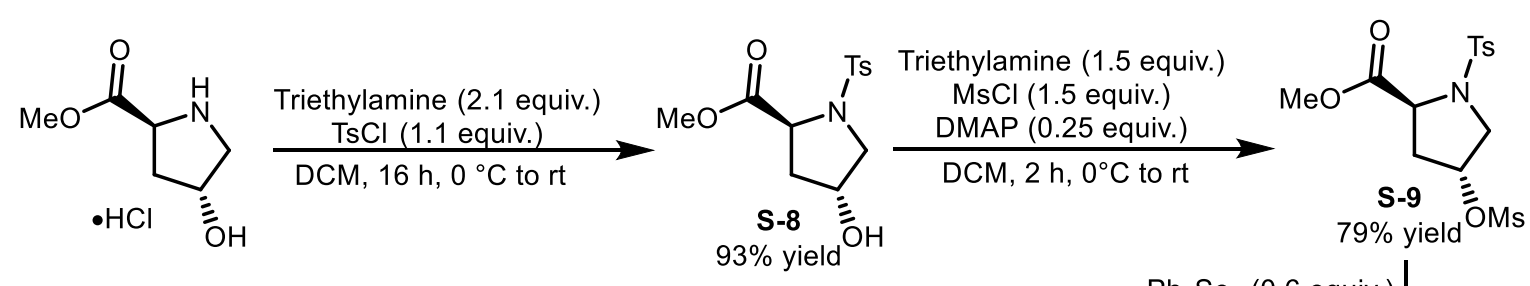

$\mathrm{Ph}_{2} \mathrm{Se}_{2}$ (0.6 equiv.)

$\mathrm{NaBH}_{4}$ (1.3 equiv.)

$\mathrm{MeOH}, 12 \mathrm{~h}$ reflux
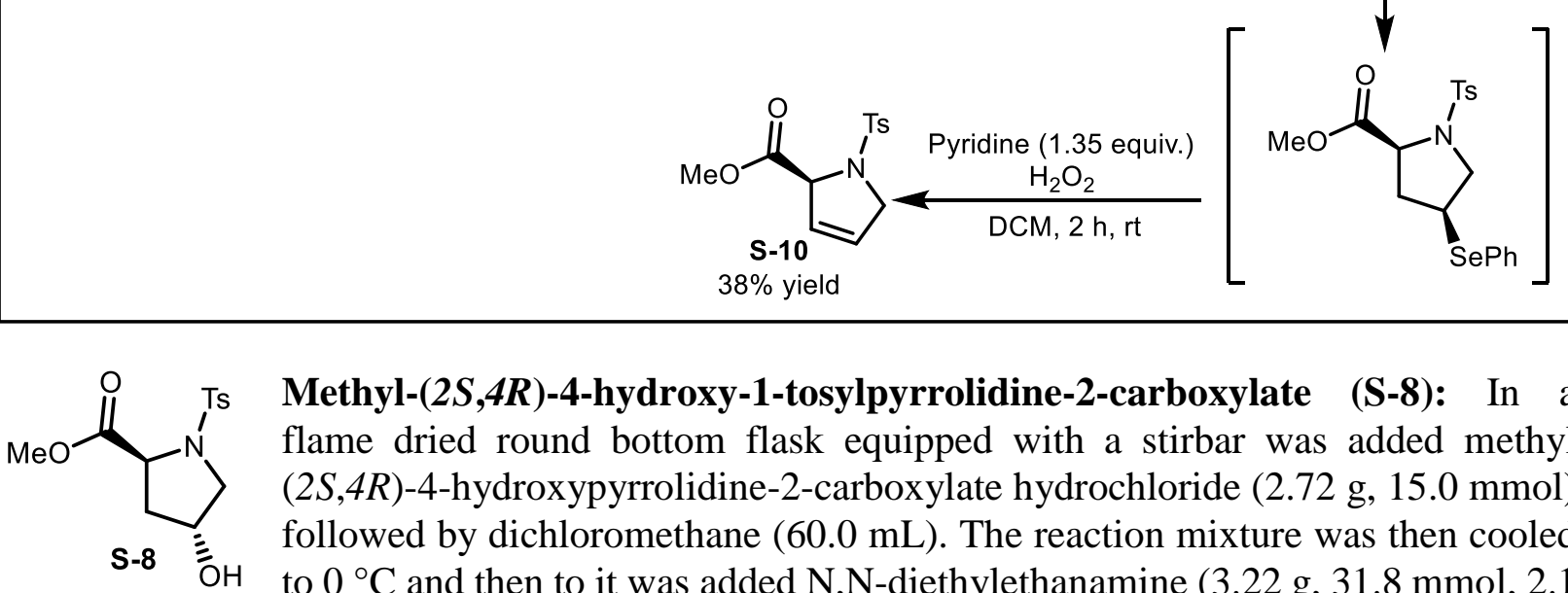

Methyl-(2S,4R)-4-hydroxy-1-tosylpyrrolidine-2-carboxylate (S-8): In a flame dried round bottom flask equipped with a stirbar was added methyl $(2 S, 4 R)$-4-hydroxypyrrolidine-2-carboxylate hydrochloride $(2.72 \mathrm{~g}, 15.0 \mathrm{mmol})$ followed by dichloromethane $(60.0 \mathrm{~mL})$. The reaction mixture was then cooled to $0{ }^{\circ} \mathrm{C}$ and then to it was added $\mathrm{N}, \mathrm{N}$-diethylethanamine $(3.22 \mathrm{~g}, 31.8 \mathrm{mmol}, 2.1$ equiv.) followed by 4-methylbenzenesulfonyl chloride (3.15 g, $16.5 \mathrm{mmol}, 1.1$ equiv.). The reaction was then warmed to room temperature and allowed to stir for 16 hours. The reaction mixture was then washed with a $1 \mathrm{M}$ citric acid solution $(60 \mathrm{~mL})$, followed by saturated sodium bicarbonate $(60 \mathrm{~mL})$, and then brine $(60 \mathrm{~mL})$. The organic layer was then collected, dried with $\mathrm{Na}_{2} \mathrm{SO}_{4}$, filtered, and concentrated under reduced pressure. No further purification was required, producing a white solid (4.16 g, 93\% yield). The spectral data was in accordance with the literature. ${ }^{9}$

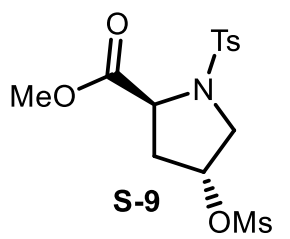

Methyl-(2S,4R)-4-((methylsulfonyl)oxy)-1-tosylpyrrolidine-2-carboxylate (S-9): This experimental procedure was adapted from the literature. ${ }^{9}$ To a flame dried round bottom flask equipped with a stirbar was added methyl-(2S,4R)-4hydroxy-1-tosylpyrrolidine-2-carboxylate (S-8) $(1.50 \mathrm{~g}, 5.00 \mathrm{mmol})$, followed by dichloromethane $(20.0 \mathrm{~mL})$. The mixture was then cooled to $0{ }^{\circ} \mathrm{C}$ and to it was added $\mathrm{N}, \mathrm{N}$-diethylethanamine $(761 \mathrm{mg}, 7.50 \mathrm{mmol}, 1.5$ equiv.) and $\mathrm{N}, \mathrm{N}-$ dimethylpyridin-4-amine ( $159 \mathrm{mg}, 1.30 \mathrm{mmol}, 0.26$ equiv.), followed by methanesulfonyl chloride ( $861 \mathrm{mg}, 7.52 \mathrm{mmol}, 1.5$ equiv.). The reaction was then warmed to room temperature and allowed to stir for two hours. The reaction mixture was then quenched with water $(20 \mathrm{~mL})$, and the layers were separated. The aqueous layer was extracted an additional two times with dichloromethane 
$(20 \mathrm{~mL})$. The organic layers were then combined and washed with brine $(60 \mathrm{~mL})$. The organic layer was then dried with $\mathrm{Na}_{2} \mathrm{SO}_{4}$, filtered, and concentrated under reduced pressure. The crude material was then purified with the use of silica gel chromatography (50:45:5 ethyl acetate:hexanes:methanol, stained in $\left.\mathrm{KMnO}_{4}\right)$ to yield a clear, colorless oil $(1.51 \mathrm{~g}$, $79 \%$ yield). ${ }^{1} \mathrm{H}$ NMR $\left(600 \mathrm{MHz}, \mathrm{CDCl}_{3}\right) \delta 7.78(\mathrm{~d}, J=8.3 \mathrm{~Hz}, 2 \mathrm{H}), 7.35(\mathrm{~d}, J=8.3 \mathrm{~Hz}, 2 \mathrm{H}), 5.21(\mathrm{~s}, 1 \mathrm{H}), 4.42$ $(\mathrm{t}, J=8.0 \mathrm{~Hz}, 1 \mathrm{H}), 4.00-3.66(\mathrm{~m}, 5 \mathrm{H}), 2.83(\mathrm{~s}, 3 \mathrm{H}), 2.54(\mathrm{ddt}, J=13.9,7.5,2.2 \mathrm{~Hz}, 1 \mathrm{H}), 2.44(\mathrm{~s}$, $3 \mathrm{H}), 2.29$ (ddd, $J=13.9,8.4,4.7 \mathrm{~Hz}, 1 \mathrm{H}) .{ }^{13} \mathrm{C}$ NMR $\left(151 \mathrm{MHz}, \mathrm{CDCl}_{3}\right) \delta 171.7,144.2,134.7$, 129.8, 127.9, 77.6, 59.2, 54.2, 52.8, 38.5, 37.5, 21.6. IR (neat) vmax 2954 (br), $1748(\mathrm{~s}), 1598(\mathrm{w})$, 1495 (w), 1438 (m), 1336 (s), 1292 (w), $1261(\mathrm{w}), 1170(\mathrm{~m}), 1156$ (s), $1094(\mathrm{~m}), 1051(\mathrm{w}), 1023$ (m), $954(\mathrm{~m}), 899(\mathrm{~s}), 842(\mathrm{w}), 817(\mathrm{~m}), 778(\mathrm{w}), 731(\mathrm{w}), 708(\mathrm{w}), 671(\mathrm{~s}), 594(\mathrm{~s}), 545(\mathrm{~s}) \mathrm{cm}^{-1}$. HRMS (DART+) m/z: [M+H] $]^{+}$Calcd for $\mathrm{C}_{14} \mathrm{H}_{20} \mathrm{NO}_{7} \mathrm{~S}_{2} 378.0676$; Found 378.0684.

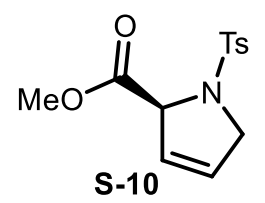

Methyl-(S)-1-tosyl-2,5-dihydro-1H-pyrrole-2-carboxylate (S-10): In a flame dried round bottom flask equipped with a stirbar was added methyl-(2S,4R)-4((methylsulfonyl)oxy)-1-tosylpyrrolidine-2-carboxylate (S-9) $\quad(1.42$ g, 3.76 $\mathrm{mmol}$ ), and diphenyl diselenide (705 mg, $2.26 \mathrm{mmol}, 0.60$ equiv.), followed by methanol $(27.5 \mathrm{~mL})$. This solution was cooled to $0{ }^{\circ} \mathrm{C}$, and to it was added sodium borohydride (188 mg, $4.97 \mathrm{mmol}, 1.32$ equiv.) in two portions. The reaction was then allowed to warm to room temperature, and then brought to reflux for twelve hours. The solvent was then removed under reduced pressure and water $(20 \mathrm{~mL})$ was then added. The aqueous layer was then washed three times with ethyl acetate $(3 \times 25 \mathrm{~mL})$. The organic layers were then combined, dried with $\mathrm{Na}_{2} \mathrm{SO}_{4}$, filtered, and concentrated under reduced pressure. The selenium intermediate was then purified with the use of silica gel chromatography (0-50\% ethyl acetate in hexanes, stained in $\mathrm{KMnO}_{4}$ ) to afford a yellow-orange oil. This oil was then added to a flame dried round bottom flask equipped with a stirbar, to which was then added pyridine ( $400 \mathrm{mg}, 5.06 \mathrm{mmol}, 1.34$ equiv.), followed by dichloromethane $(20.0 \mathrm{~mL})$. To the reaction was added hydrogen peroxide, $35 \%$ aq. Solution $(1.00 \mathrm{~mL})$ dropwise, and the reaction was then sealed with a septum and allowed to stir at room temperature for two hours. Water $(20 \mathrm{~mL})$ was then added to the reacton mixture, and the layers were separated. The organic later was washed with a $1 \mathrm{M}$ citric acid solution $(25 \mathrm{~mL})$, followed by saturated sodium thiosulfate $(25 \mathrm{~mL})$, and then brine $(25 \mathrm{~mL})$. The organic layer was then dried with $\mathrm{Na}_{2} \mathrm{SO}_{4}$, filtered, and concentrated under reduced pressure. The crude reaction mixture was then purified with the use of silica gel chromatography (15-25\% ethyl acetate in hexanes, stained in $\mathrm{KMnO}_{4}$ ), to afford a white solid (401 mg, 38\% yield). ${ }^{1} \mathrm{H}$ NMR (500 MHz, $\left.\mathrm{CDCl}_{3}\right) \delta 7.78(\mathrm{~d}, J=7.9 \mathrm{~Hz}, 2 \mathrm{H}), 7.32(\mathrm{~d}, J=7.9 \mathrm{~Hz}, 2 \mathrm{H}), 5.85(\mathrm{dd}, J=4.2,2.2 \mathrm{~Hz}, 1 \mathrm{H}), 5.66$ $(\mathrm{td}, J=4.6,2.4 \mathrm{~Hz}, 1 \mathrm{H}), 5.13(\mathrm{~d}, J=2.2 \mathrm{~Hz}, 1 \mathrm{H}), 4.20(\mathrm{dd}, J=4.6,2.4 \mathrm{~Hz}, 2 \mathrm{H}), 3.75(\mathrm{~s}, 3 \mathrm{H}), 2.43$ (s, 3H). ${ }^{13} \mathrm{C}$ NMR $\left(151 \mathrm{MHz}, \mathrm{CDCl}_{3}\right) \delta 170.0,143.7,134.9,129.7,128.5,127.3,124.5,68.0,55.0$, 52.4, 21.4. IR (neat) vmax 2953 (br), 1756 (s), 1597 (m), $1494(\mathrm{w}), 1436(\mathrm{~m}), 1342(\mathrm{~s}), 1279(\mathrm{w})$, 1200 (m), 1158 (s), 1093 (s), 1069 (m), 1017 (m), 986 (w), 959 (w), $913(\mathrm{w}), 852(\mathrm{w}), 815(\mathrm{~m})$, $775(\mathrm{~m}), 731(\mathrm{~m}), 707(\mathrm{~m}), 664(\mathrm{~s}), 595(\mathrm{~s}), 547(\mathrm{~s}) \mathrm{cm}^{-1}$. HRMS (DART+) m/z: [M+H] ${ }^{+}$Calcd for $\mathrm{C}_{13} \mathrm{H}_{16} \mathrm{NO}_{4} \mathrm{~S}$ 282.0795; Found 282.0795. 

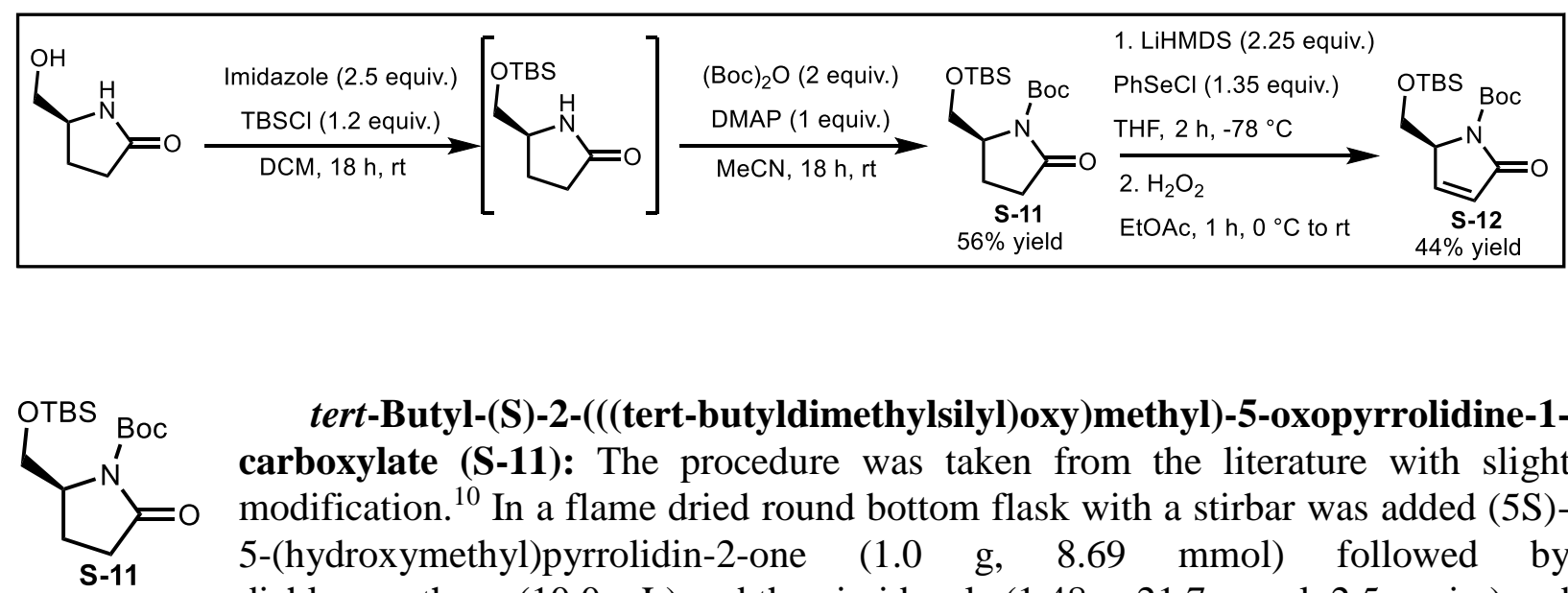

tert-Butyl-(S)-2-(((tert-butyldimethylsilyl)oxy)methyl)-5-oxopyrrolidine-1carboxylate (S-11): The procedure was taken from the literature with slight modification. ${ }^{10}$ In a flame dried round bottom flask with a stirbar was added (5S)5-(hydroxymethyl)pyrrolidin-2-one $(1.0 \mathrm{~g}, \quad 8.69 \mathrm{mmol})$ followed by dichloromethane $(10.0 \mathrm{~mL})$ and then imidazole $(1.48 \mathrm{~g}, 21.7 \mathrm{mmol}, 2.5$ equiv.) and tert-butyl-chloro-dimethyl-silane (1.57 g, $10.4 \mathrm{mmol}, 1.2$ equiv.) and allowed to stir for 18 hours at room temperature. The solution was diluted with diethyl ether $(40 \mathrm{~mL})$ and then the organic layer was washed with water $(50 \mathrm{~mL})$, followed by brine $(50 \mathrm{~mL})$. The organic layer was then dried with $\mathrm{MgSO}_{4}$, filtered, and then concentrated under reduced pressure. To the collected intermediate was added acetonitrile $(70.0 \mathrm{~mL})$ and then cooled to $0{ }^{\circ} \mathrm{C}$ where to it was added N,Ndimethylpyridin-4-amine (1.06 g, $8.69 \mathrm{mmol}, 1.0$ equiv.) and ditert-butyl propanedioate (3.76 g, $17.4 \mathrm{mmol}, 2.0$ equiv.) and was then sealed, flushed with nitrogen, and allowed to stir for 18 hours at room temperature. The organic phase was washed three times with brine $(80 \mathrm{~mL})$, and then dried over $\mathrm{MgSO}_{4}$, filtered, and then concentrated under reduced pressure. The crude reaction material was purified with the use of silica gel chromatography (10-30\% ethyl acetate in hexanes, stained in CAM) to afford a yellow oil (1.68 g, $56 \%$ yield). The spectral data were in accordance with the literature. $^{10}$

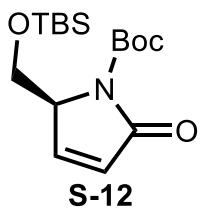

tert-Butyl-(S)-2-(((tert-butyldimethylsilyl)oxy)methyl)-5-oxo-2,5-dihydro-1Hpyrrole-1-carboxylate (S-12): To a flame dried round bottom flask with a stirbar in the glovebox was added [bis(trimethylsilyl)amino]lithium (1.93 g, $11.5 \mathrm{mmol}$, 2.25 equiv.) and cooled to $-78^{\circ} \mathrm{C}$. A solution consisting of tert-butyl (2S)-2-[[tertbutyl(dimethyl)silyl]oxymethyl]-5-oxo-pyrrolidine-1-carboxylate (S-11) (1.68 g, $5.10 \mathrm{mmol})$ and tetrahydrofuran $(3.00 \mathrm{~mL})$ was added slowly to the reaction at $-78{ }^{\circ} \mathrm{C}$ and allowed to stir at this temperature for one hour. At this temperature, phenyl selenohypochlorite $(1.32 \mathrm{~g}$, 6.89 mmol, 1.35 equiv.) was added as a 3.6M solution (THF: $2.00 \mathrm{~mL}$ ) dropwise, and left to stir at this temperature for 45 minutes. The reaction was quenched with saturated ammonium chloride $(10 \mathrm{~mL})$ and allowed to stir for 10 minutes. The reaction was then transferred to a separation funnel, where it was partitioned between saturated sodium bicarbonate $(50 \mathrm{~mL})$ and diethyl ether $(50 \mathrm{~mL})$, and the aqueous layer was extracted an additional two times with diethyl ether $(2 \times 50$ $\mathrm{mL}$ ). The aqueous layer was once again extracted with diethyl ether, and all of the combined layers were washed with brine $(100 \mathrm{~mL})$, dried over $\mathrm{MgSO}_{4}$, and then concentrated under reduced pressure. The isolated compound was then dissolved in ethyl acetate $(15 \mathrm{~mL})$ and then cooled to 0 ${ }^{\circ} \mathrm{C}$ and hydrogen peroxide (32-36\% aqueous solution) $(4.00 \mathrm{~mL})$ was added dropwise over 10 minutes. The mixture was left to stir at this temperature for 15 minutes, and then stirred at room temperature for an additional hour. The mixture was poured into a separation funnel containing saturated sodium bicarbonate $(50 \mathrm{~mL})$, and the aqueous layer was washed with ethyl acetate an 
additional two times $(2 \times 50 \mathrm{~mL})$. The organic layer was then washed with brine $(100 \mathrm{~mL})$, dried over $\mathrm{Na}_{2} \mathrm{SO}_{4}$, and concentrated under reduced pressure. The crude material was then purified with the use of silica gel chromatography (10-20\% ethyl acetate in hexanes, stained in $\left.\mathrm{KMnO}_{4}\right)$ to yield a white solid (734 mg, $44 \%$ yield). All spectral data were in accordance with the literature. ${ }^{10}$
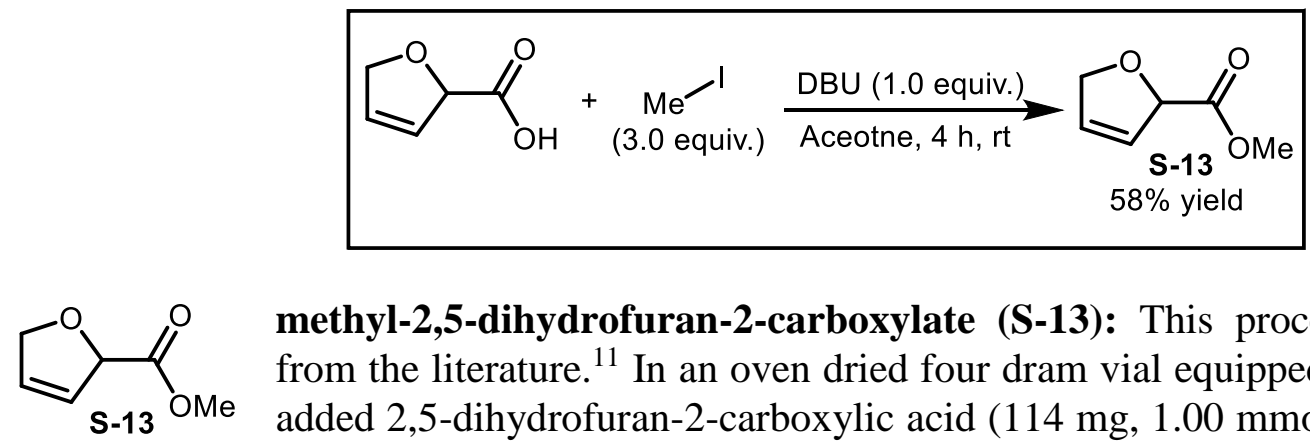

methyl-2,5-dihydrofuran-2-carboxylate (S-13): This procedure was adapted from the literature. ${ }^{11}$ In an oven dried four dram vial equipped with a stirbar was added 2,5-dihydrofuran-2-carboxylic acid (114 mg, $1.00 \mathrm{mmol})$, followed by dry acetone $(5.00 \mathrm{~mL})$, and 2,3,4,6,7,8,9,10-octahydropyrimido[1,2-a]azepine (152 $\mathrm{mg}, 1.00 \mathrm{mmol}, 1.0$ equiv.) and allowed to stir at room temperature for ten minutes. Then, iodomethane (426 mg, $3.00 \mathrm{mmol}, 3.0$ equiv.) was added dropwise over the course of ten minutes. The reaction vial was then sealed with a septum and allowed to stir for four hours at room temperature. The reaction was then carefully concentrated under reduced pressure. The reaction mixture was then partitioned between diethyl ether $(15 \mathrm{~mL})$ and brine $(15 \mathrm{~mL})$. The layers were then separated and the aqueous layer was washed an additional two times with diethyl ether (2x15 $\mathrm{mL}$ ). The organic layers were then combined, dried with $\mathrm{MgSO}_{4}$, filtered, and concentrated under reduced pressure. The crude reaction mixture was purified with the use of silica gel chromatography ( $10 \%$ diethyl ether in pentane, stained in $\left.\mathrm{KMnO}_{4}\right)$ to yield a clear, colorless liquid (74.5 mg, $58 \%$ yield). The spectral data were in accordance with the literature. ${ }^{12}$

\section{General Procedure for the diboration of cyclic alkenyl substrates with Pt(dba) 3 (Method 1)}

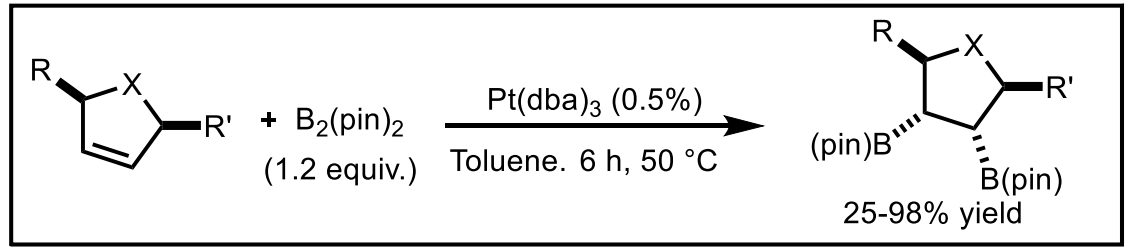

To an oven dried two dram vial equipped with a stir bar was added cyclic alkenyl substrate (0.20 mmol) followed by bis(pinacolato)diboron $(61.0 \mathrm{mg}, 0.240 \mathrm{mmol}, 1.2$ equiv.). Then, tris(dibenzylideneacetone)platinum(0) $(0.9 \mathrm{mg}, 1.00 \mu \mathrm{mol}, 0.5 \%)$ was added, followed by toluene $(0.60 \mathrm{~mL})$. The reaction vial was then sealed under air with a septum, and allowed to stir for six hours at $50{ }^{\circ} \mathrm{C}$. The reaction was then concentrated under reduced pressure, and the crude reaction material was purified with the use of silica gel chromatography. 
Vendola, Allais, Dechert Schmitt, Lee, Singer, and Morken Supplementary Information

IV: $\quad$ General Procedure for the diboration of cyclic alkenyl substrates with Pt/C (Method 2)

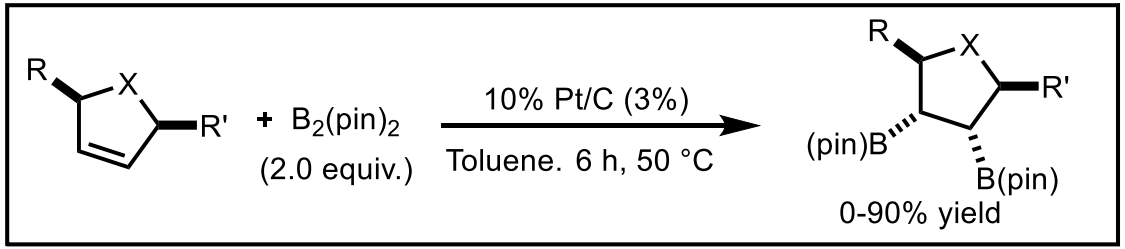

To an oven dried two dram vial equipped with a stirbar was added cyclic alkenyl substrate ( $0.20 \mathrm{mmol})$ followed by bis(pinacolato)diboron $(102 \mathrm{mg}, 0.400 \mathrm{mmol}, 2.0$ equiv.). To the reaction mixture was then added $10 \%$ platinum on carbon $(7.80 \mathrm{mg}, 6.00 \mu \mathrm{mol}, 3.0 \%)$ followed by toluene $(0.60 \mathrm{~mL})$. The reaction mixture was then sealed with a septum under air and allowed to stir at 50 ${ }^{\circ} \mathrm{C}$ for six hours. The reaction mixture was then filtered through a plug of silica gel using diethyl ether, and then concentrated under reduced pressure. The crude reaction mixture was then purified with the use of silica gel chromatography.

\section{V: Characterization of cyclic alkene diboration products and analysis of stereochemistry (Method 1)}

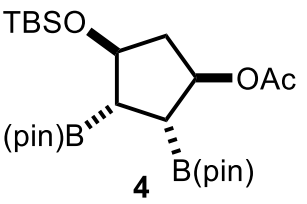

[4-[tert-Butyl(dimethyl)silyl]oxy-2,3-bis(4,4,5,5-tetramethyl-1,3,2dioxaborolan-2-yl)cyclopentyl] acetate (4): The reaction was performed according to the general procedure (method 1) with [4-[tertbutyl(dimethyl)silyl]oxycyclopent-2-en-1-yl] acetate $(51.3 \mathrm{mg}, 0.20 \mathrm{mmol})$, bis(pinacolato)diboron (61.0 $\mathrm{mg}, \quad 0.240 \quad \mathrm{mmol}, \quad 1.2$ equiv.), tris(dibenzylideneacetone)platinum(0) $(0.9 \mathrm{mg}, 1.00 \mu \mathrm{mol}, 0.5 \%)$ and toluene $(0.60 \mathrm{~mL})$. The reaction was allowed to stir for six hours at $50{ }^{\circ} \mathrm{C}$, and then concentrated under reduced pressure. The crude reaction mixture was purified with the use of silica gel chromatography (5\% ethyl acetate in hexanes, stained in CAM) to yield a colorless oil (100 mg, 98\% yield). ${ }^{1} \mathrm{H}$ NMR (500 $\left.\mathrm{MHz} \mathrm{CDCl}_{3}\right) \delta 5.10(\mathrm{ddd}, J=7.1,4.4,2.7 \mathrm{~Hz}, 1 \mathrm{H}), 4.26(\mathrm{td}, J=6.2,3.6 \mathrm{~Hz}, 1 \mathrm{H}), 2.31(\mathrm{dt}, J=$ $14.1,7.1 \mathrm{~Hz}, 1 \mathrm{H}), 1.98,(\mathrm{~s}, 3 \mathrm{H}), 1.88(\mathrm{dd}, J=8.1,4.4 \mathrm{~Hz}, 1 \mathrm{H}), 1.73-1.69(\mathrm{~m}, 1 \mathrm{H}), 1.51$ (dddt, $J=$ 14.7, 3.8, 2.7, 1.3 Hz, 1H), $1.21(\mathrm{~d}, J=2.3 \mathrm{~Hz}, 24 \mathrm{H}), 0.85(\mathrm{~s}, 9 \mathrm{H}), 0.03(\mathrm{~d}, J=6.5 \mathrm{~Hz}, 6 \mathrm{H}) .{ }^{13} \mathrm{C}$ NMR $\left(126 \mathrm{MHz} \mathrm{CDCl}_{3}\right) \delta 171.2,83.4,83.2,78.0,74.7,43.5,25.9,25.1,25.0,24.89,24.87,21.5$, 18.1, -4.6. (Due to the quadrupolar nature of boron, the carbon adjacent to boron was not detectable.) ${ }^{11} \mathrm{~B}$ NMR $\left(160 \mathrm{MHz}, \mathrm{CDCl}_{3}\right) \delta 34.45$. IR (neat) $v_{\max } 2977(\mathrm{~m}), 2929(\mathrm{~m}), 2856(\mathrm{w})$, 1735 (s), 1472 (w), 1368 (s), 1321 (s), 1249 (s), 1215 (m), 1166 (w), 1141 (s), 1109 (w), 1072 (w), 1016 (w), 969 (w), 935 (w), 899 (m), 864 (m), $851(\mathrm{w}), 837(\mathrm{~m}), 775(\mathrm{~m}), 667(\mathrm{w}), 579(\mathrm{w}) \mathrm{cm}^{-1}$. HRMS (DART+) m/z: [M+H] ${ }^{+}$Calcd for $\mathrm{C}_{25} \mathrm{H}_{49} \mathrm{~B}_{2} \mathrm{O}_{7} \mathrm{Si}$ 511.3428; Found 511.3429.

\section{Analysis of Stereochemistry:}

The relative configuration was determined by analogy via the total synthesis of 3-(4-amino- $1 \mathrm{H}-$ benzo[d]imidazol-1-yl)-5-(hydroxymethyl)cyclopentane-1,2-diol $(( \pm)$-aristeromycin). The spectral data of synthesized $( \pm)$-aristeromycin via tert-Butyl-N-[4-[[tertbutyl(diphenyl)silyl]oxymethyl]-2,3-bis(4,4,5,5-tetramethyl-1,3,2-dioxaborolan-2-

yl)cyclopentyl]carbamate (7) was in accordance with the literature. ${ }^{8}$ The diastereoselectivity was determined to be $>20: 1$, as no additional diastereomer could be detected by ${ }^{1} \mathrm{H}$ and ${ }^{13} \mathrm{C}$ NMR. 
Vendola, Allais, Dechert Schmitt, Lee, Singer, and Morken Supplementary Information

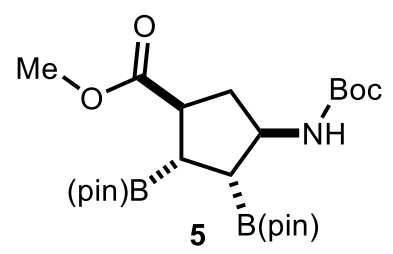

Methyl-4-((tert-butoxycarbonyl)amino)-2,3-bis(4,4,5,5-tetramethyl1,3,2-dioxaborolan-2-yl)cyclopentane-1-carboxylate (5): The reaction was performed according to the general procedure (method 1) with cismethyl 4-(tert-butoxycarbonylamino)cyclopent-2-ene-1-carboxylate (48.3 mg, $0.2 \mathrm{mmol}$ ), bis(pinacolato)diboron $(61.0 \mathrm{mg}, 0.24 \mathrm{mmol}, 1.2$ equiv.), tris(dibenzylideneacetone)platinum(0) $(0.9 \mathrm{mg}, 1.00 \mu \mathrm{mol}$, $0.5 \%)$ and toluene $(0.60 \mathrm{~mL})$. The reaction was allowed to stir for six hours at $50{ }^{\circ} \mathrm{C}$, and was then concentrated under reduced pressure. The crude reaction mixture was purified with the use of silica gel chromatography, (10\% ethyl acetate in hexanes, stained in CAM) to yield a white solid (77.3 mg, 78\% yield). ${ }^{1} \mathrm{H}$ NMR $\left(500 \mathrm{MHz}, \mathrm{CDCl}_{3}\right) \delta 4.96(\mathrm{~s}, 1 \mathrm{H}), 4.17$ (s, 1H), $3.66(\mathrm{~s}, 3 \mathrm{H}), 2.93$ (td, $J$ $=9.2,5.4 \mathrm{~Hz}, 1 \mathrm{H}), 2.31(\mathrm{dt}, J=15.6,9.2 \mathrm{~Hz}, 1 \mathrm{H}), 1.81(\mathrm{t}, J=8.2 \mathrm{~Hz}, 1 \mathrm{H}), 1.68$ (dddd, J = 15.6, $5.4,2.9,1.3 \mathrm{~Hz}, 1 \mathrm{H}), 1.61$ (dd, J = 8.2, $3.8 \mathrm{~Hz}, 1 \mathrm{H}), 1.42(\mathrm{~s}, 9 \mathrm{H}), 1.26-1.18(\mathrm{~m}, 24 \mathrm{H}) .{ }^{13} \mathrm{C} \mathrm{NMR}$ $\left(126 \mathrm{MHz}, \mathrm{CDCl}_{3}\right) \delta 177.9,155.2,83.53,83.52,54.8,51.9,44.4,37.2,28.7,28.6,25.1,24.92$, $24.85,24.7$. (Due to the quadrupolar nature of boron, the carbon adjacent to boron was not detectable.) ${ }^{11} \mathrm{~B}$ NMR $\left(160 \mathrm{MHz}, \mathrm{CDCl}_{3}\right) \delta$ 34.44. IR (neat) $v_{\max } 3378$ (br), 2977 (w), 1712 (s), 1504 (m), 1380 (m), 1370 (m), 1320 (m), 1244 (w), 1224 (w), 1165 (m), 1141 (s), 1109 (w), 1057 (w), 1008 (w), $991(\mathrm{w}), 969(\mathrm{w}), 919(\mathrm{w}), 852(\mathrm{~m}), 778(\mathrm{w}), 732(\mathrm{~m}), 667(\mathrm{w}), 647(\mathrm{w}), 579(\mathrm{w})$ $\mathrm{cm}^{-1}$. HRMS (DART+) m/z: [M+H] ${ }^{+}$Calcd for $\mathrm{C}_{24} \mathrm{H}_{44} \mathrm{~B}_{2} \mathrm{NO}_{8} 496.3248$; Found 496.3269 .

\section{Analysis of Stereochemistry:}

The relative configuration was determined by analogy via the total synthesis of 3-(4-amino- $1 \mathrm{H}-$ benzo[d]imidazol-1-yl)-5-(hydroxymethyl)cyclopentane-1,2-diol $\quad(( \pm)$-aristeromycin). The spectral data of synthesized $( \pm)$-aristeromycin via tert-Butyl-N-[4-[[tertbutyl(diphenyl)silyl]oxymethyl]-2,3-bis(4,4,5,5-tetramethyl-1,3,2-dioxaborolan-2-

yl)cyclopentyl]carbamate (7) was in accordance with the literature. ${ }^{8}$ The diastereoselectivity was determined to be $>20: 1$, as no additional diastereomer could be detected by ${ }^{1} \mathrm{H}$ and ${ }^{13} \mathrm{C}$ NMR.

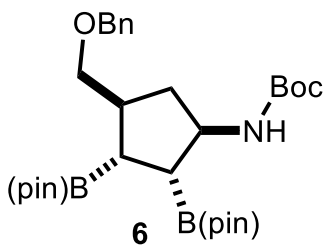

tert-Butyl-4-((benzyloxy)methyl)-2,3-bis(4,4,5,5-tetramethyl-1,3,2dioxaborolan-2-yl)cyclopentyl)carbamate (6): The reaction was performed according to the general procedure (method 1) with tert-butyl N[4-(benzyloxymethyl)cyclopent-2-en-1-yl]carbamate (60.7 mg, $0.20 \mathrm{mmol}$ ), bis(pinacolato)diboron (61.0 $\mathrm{mg}, \quad 0.240 \quad \mathrm{mmol}, \quad 1.2$ equiv.), tris(dibenzylideneacetone)platinum(0) $(0.9 \mathrm{mg}, 1.00 \mu \mathrm{mol}, 0.5 \%)$ and toluene $(0.60 \mathrm{~mL})$. The reaction was allowed to stir for six hours at $50{ }^{\circ} \mathrm{C}$, and then concentrated under reduced pressure. The crude reaction mixture was purified with the use of silica gel chromatography (5-10\% ethyl acetate in hexanes, stained in CAM) to afford a white solid (66.9 $\mathrm{mg}, 60 \%$ yield). ${ }^{1} \mathrm{H}\left(500 \mathrm{MHz}, \mathrm{CDCl}_{3}\right) \delta$ 7.36-7.30 (m, 4H), 7.28-7.23 (m, 1H), $5.21(\mathrm{~s}, 1 \mathrm{H}), 4.51$ (s, 2H), 4.08 (s, 1H) 3.47 (dd, $J=8.8,4.3 \mathrm{~Hz}, 1 \mathrm{H}), 3.39$ (dd, $J=8.8,4.3 \mathrm{~Hz}, 1 \mathrm{H}), 2.36$ (ddt, $J=$ 14.6, 9.7, 4.3 Hz, 1H), 2.17 (ddd, $J=13.7,10.6,6.7 \mathrm{~Hz}, 1 \mathrm{H}), 1.57$ (d, J = 7.8 Hz, 1H), 1.51-1.45 $(\mathrm{m}, 1 \mathrm{H}), 1.39(\mathrm{~s}, 9 \mathrm{H}), 1.34-1.29(\mathrm{~m}, 1 \mathrm{H}), 1.24-1.18(\mathrm{~m}, 24 \mathrm{H}) .{ }^{13} \mathrm{C}$ NMR $\left(126 \mathrm{MHz}, \mathrm{CDCl}_{3}\right) \delta$ 155.1, 138.6, 128.3, 127.6, 127.4, 83.1, 82.9, 73.6, 73.1, 54.8, 39.8, 36.6, 33.3, 28.5, 25.0, 24.9, 24.8, 24.7. (Due to the quadrupolar nature of boron, the carbon adjacent to boron was not detectable.) ${ }^{11} \mathrm{~B}$ NMR $\left(160 \mathrm{MHz}, \mathrm{CDCl}_{3}\right) \delta$ 34.77. IR (neat) $v_{\max } 3378$ (br), $2977(\mathrm{w}), 2931(\mathrm{w})$, 2248 (w), 1706 (s), 1499 (m), 1454 (w), 1411 (w), 1378 (m), 1370 (m), $1314(\mathrm{~m}), 1239(\mathrm{w}), 1166$ (m), 1141 (s), 1101 (m), 1059 (w), 1028 (w), 991 (w), 887 (w), 852 (m), 731 (s), 398 (m), 668 (w), 
$646(\mathrm{w}), 579(\mathrm{w}) \mathrm{cm}^{-1}$. HRMS (DART+) m/z: $[\mathrm{M}+\mathrm{H}]^{+}$Calcd for $\mathrm{C}_{30} \mathrm{H}_{50} \mathrm{~B}_{2} \mathrm{NO}_{7}$ 558.3769; Found 558.3793 .

\section{Analysis of Stereochemistry:}

The relative configuration was determined by analogy via the total synthesis of 3-(4-amino- $1 \mathrm{H}-$ benzo[d]imidazol-1-yl)-5-(hydroxymethyl)cyclopentane-1,2-diol $\quad(( \pm)$-aristeromycin). The spectral data of synthesized $( \pm)$-aristeromycin via tert-Butyl-N-[4-[[tertbutyl(diphenyl)silyl]oxymethyl]-2,3-bis(4,4,5,5-tetramethyl-1,3,2-dioxaborolan-2-

yl)cyclopentyl]carbamate (7) was in accordance with the literature. ${ }^{8}$ Diastereoselectivity was obtained from analysis of the crude reaction mixture by ${ }^{13} \mathrm{C}$ NMR, and was determined to be 4:1.

Isolated stereoisomer $\left({ }^{13} \mathrm{C}\right)$ :

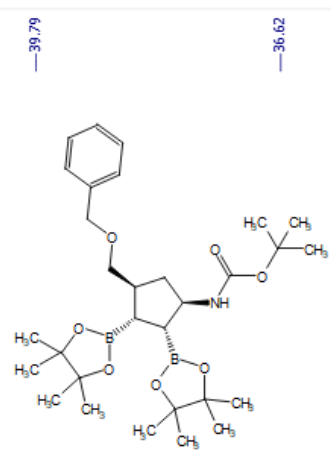

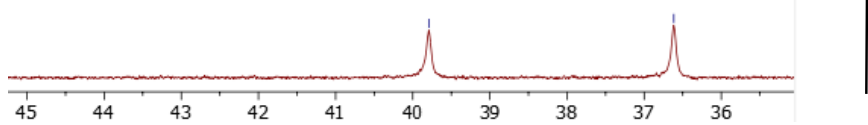

Crude reaction $\left({ }^{13} \mathrm{C}\right)$
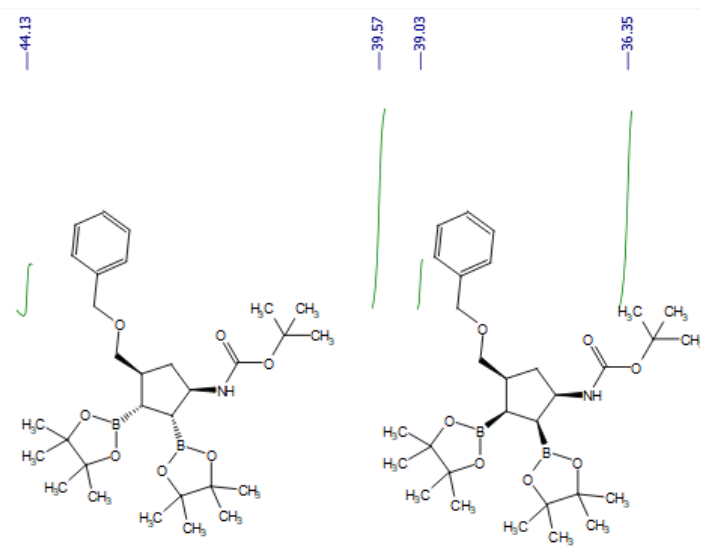

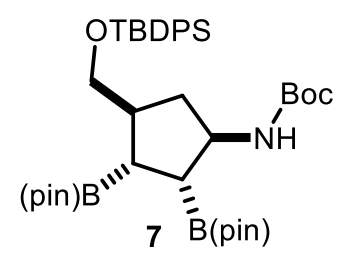

tert-Butyl-N-[4-[[tert-butyl(diphenyl)silyl]oxymethyl]-2,3-bis(4,4,5,5tetramethyl-1,3,2-dioxaborolan-2-yl)cyclopentyl]carbamate (7): The reaction was performed according to the general procedure (method 1) with tert-butyl-((cis)-4-(((tert-butyldiphenylsilyl)oxy)methyl)cyclopent-2-en-1yl)carbamate $(90.3 \mathrm{mg}, 0.20 \mathrm{mmol})$, bis(pinacolato)diboron $(61.0 \mathrm{mg}, 0.240$ mmol, 1.2 equiv.), tris(dibenzylideneacetone)platinum(0) $(0.9 \mathrm{mg}, 1.00$ $\mu \mathrm{mol}, 0.5 \%)$ and toluene $(0.60 \mathrm{~mL})$. The reaction was allowed to stir for six hours at $50{ }^{\circ} \mathrm{C}$, and then concentrated under reduced pressure. The crude reaction mixture was purified with the use of silica gel chromatography (5-20\% ethyl acetate in hexanes, stained in CAM) to afford a white solid (86.1 mg, 61\% yield). ${ }^{1} \mathrm{H}\left(600 \mathrm{MHz}, \mathrm{CDCl}_{3}\right) \delta 7.67(\mathrm{~d}, J=7.3 \mathrm{~Hz}, 4 \mathrm{H}), 7.43-7.34(\mathrm{~m}, 6 \mathrm{H}), 5.09$ $(\mathrm{s}, 1 \mathrm{H}), 4.14(\mathrm{~s}, 1 \mathrm{H}), 3.61(\mathrm{dd}, J=10.0,3.9 \mathrm{~Hz}, 1 \mathrm{H}), 3.58(\mathrm{dd}, J=10.0,3.9 \mathrm{~Hz}, 1 \mathrm{H}), 2.26$ (ddd, $J$ $=13.6,10.0,4.5 \mathrm{~Hz}, 1 \mathrm{H}), 2.18(\mathrm{ddd}, J=13.6,11.6,6.8 \mathrm{~Hz}, 1 \mathrm{H}), 1.67-1.61(\mathrm{~m}, 1 \mathrm{H}), 1.57(\mathrm{~d}, J=$ 
$11.6 \mathrm{~Hz}, 2 \mathrm{H}), 1.40(\mathrm{~s}, 9 \mathrm{H}), 1.19(\mathrm{t}, J=11.6 \mathrm{~Hz}, 24 \mathrm{H}), 1.06(\mathrm{~s}, 9 \mathrm{H}) .{ }^{13} \mathrm{C} \mathrm{NMR}\left(101 \mathrm{MHz}, \mathrm{CDCl}_{3}\right)$ $\delta 155.1,135.8,133.6,129.6,127.7,83.2,83.0,66.1,54.9,41.7,36.1,28.6,27.1,27.0,25.1,24.9$, 24.8, 24.7, 19.3. (Due to the quadrupolar nature of boron, the carbon adjacent to boron was not detectable.) ${ }^{11} \mathrm{~B}$ NMR $\left(160 \mathrm{MHz}, \mathrm{CDCl}_{3}\right) \delta 35.31$. IR (neat) $v_{\max } 3417$ (br), $2976(\mathrm{~m}), 2931(\mathrm{~m})$, 2858 (w), 1713 (s), 1500 (m), 1428 (w), 1412 (w), 1379 (s), 1016 (m), 1237 (br), 1167 (m), 1146 (s), $1111(\mathrm{~m}), 1036(\mathrm{w}), 994(\mathrm{w}), 969(\mathrm{w}), 923(\mathrm{w}), 852(\mathrm{w}), 824(\mathrm{w}), 785(\mathrm{w}), 739(\mathrm{w}), 702(\mathrm{~m})$, $623(\mathrm{w}), 578(\mathrm{w}) \mathrm{cm}^{-1}$. HRMS (DART+) m/z: $[\mathrm{M}+\mathrm{H}]^{+}$Calcd for $\mathrm{C}_{39} \mathrm{H}_{62} \mathrm{~B}_{2} \mathrm{NO}_{7} \mathrm{Si}$ 706.4476 Found 706.4484 .

\section{Analysis of Stereochemistry:}

The relative configuration was determined via the total synthesis of 3-(4-amino- $1 \mathrm{H}-$ benzo[d]imidazol-1-yl)-5-(hydroxymethyl)cyclopentane-1,2-diol $\quad(( \pm)$-aristeromycin). The spectral data of synthesized $( \pm)$-aristeromycin via tert-Butyl-N-[4-[[tertbutyl(diphenyl)silyl]oxymethyl]-2,3-bis(4,4,5,5-tetramethyl-1,3,2-dioxaborolan-2-

yl)cyclopentyl]carbamate (7) was in accordance with the literature. ${ }^{8}$ Diastereoselectivity was obtained from analysis of the crude reaction mixture by ${ }^{13} \mathrm{C} N \mathrm{NMR}$, and was determined to be $16: 1$. The stereoisomers were unable to be separated by silica gel chromatography.
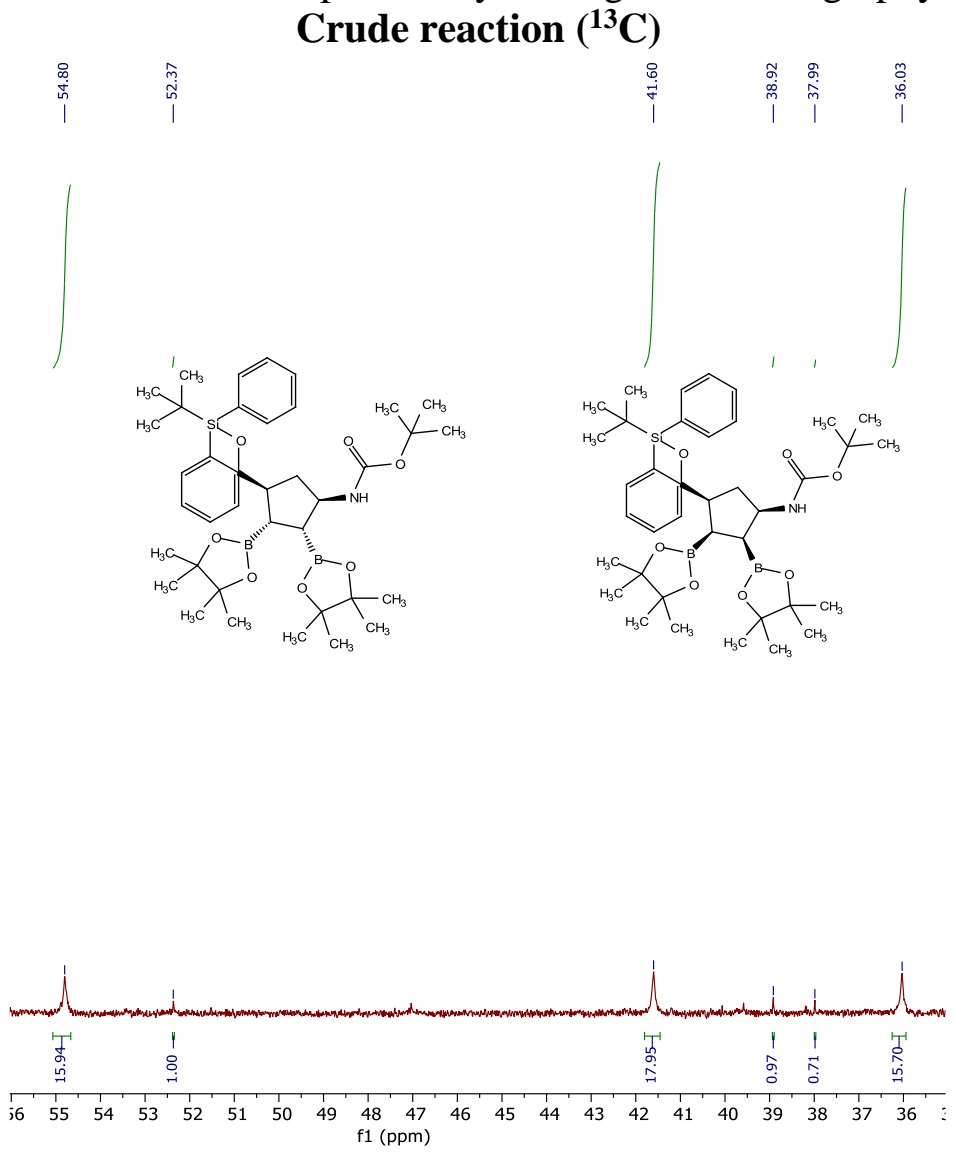


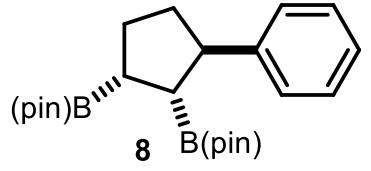

2,2'-(3-Phenylcyclopentane-1,2-diyl)bis(4,4,5,5-tetramethyl-1,3,2dioxaborolane) (8): The reaction was performed according to the general procedure (method 1) with cyclopent-2-en-1-ylbenzene (28.8 mg, 0.20 $\mathrm{mmol}$ ), bis(pinacolato)diboron (61.0 $\mathrm{mg}, 0.240 \mathrm{mmol}, 1.2$ equiv.), tris(dibenzylideneacetone)platinum(0) $(0.9 \mathrm{mg}, 1.00 \mu \mathrm{mol}, 0.5 \%)$ and toluene $(0.60 \mathrm{~mL})$. The reaction was allowed to stir for six hours at $50{ }^{\circ} \mathrm{C}$, and the reaction was then concentrated under reduced pressure. The crude reaction mixture was purified with the use of silica gel chromatography (3\% ethyl acetate in hexanes, stained in CAM) to afford a colorless oil (50.1 $\mathrm{mg}$, $65 \%$ yield). ${ }^{1} \mathrm{H}\left(600 \mathrm{MHz}, \mathrm{CDCl}_{3}\right) \delta 7.23(\mathrm{dd}, J=13.9,6.6 \mathrm{~Hz}, 4 \mathrm{H}), 7.11(\mathrm{t}, J=6.9 \mathrm{~Hz}, 1 \mathrm{H}), 3.19$ (q, $J=8.2 \mathrm{~Hz}, 1 \mathrm{H}), 2.12(\mathrm{ddt}, J=13.1,8.2,4.2 \mathrm{~Hz}, 1 \mathrm{H}), 1.95(\mathrm{dtd}, J=13.1,8.2,5.3 \mathrm{~Hz}, 1 \mathrm{H}), 1.85$ $-1.77(\mathrm{~m}, 1 \mathrm{H}), 1.69(\mathrm{td}, J=14.8,13.0,8.2 \mathrm{~Hz}, 2 \mathrm{H}), 1.61-1.51(\mathrm{~m}, 1 \mathrm{H}), 1.25(\mathrm{~s}, 12 \mathrm{H}), 1.17(\mathrm{~d}, J$ $=17.7 \mathrm{~Hz}, 12 \mathrm{H}) .{ }^{13} \mathrm{C} \mathrm{NMR}\left(151 \mathrm{MHz}, \mathrm{CDCl}_{3}\right) \delta 147.7,128.0,127.5,125.5,83.1,83.0,48.2,35.8$, 29.6, 25.3, 25.1, 24.9, 24.6. (Due to the quadrupolar nature of boron, the carbon adjacent to boron was not detectable.) ${ }^{11} \mathrm{~B}$ NMR $\left(160 \mathrm{MHz}, \mathrm{CDCl}_{3}\right) \delta 35.14$. IR (neat) $v_{\max } 2976(\mathrm{~m}), 1602(\mathrm{w})$, 1467 (w), 1411 (w), 1377 (s), 1314 (s), 1272 (w), 1214 (w), 1142 (s), 1109 (w), 1030 (m), 969 (w), $885(\mathrm{w}), 859(\mathrm{~m}), 757(\mathrm{w}), 669(\mathrm{~m}), 667(\mathrm{w}), 578(\mathrm{w}) \mathrm{cm}^{-1}$. HRMS (DART+) m/z: [M+H] Calcd for $\mathrm{C}_{23} \mathrm{H}_{37} \mathrm{~B}_{2} \mathrm{O}_{4}$ 399.2873; Found 399.2889.

\section{Analysis of Stereochemistry:}

The relative configuration was determined via the total synthesis of 3-(4-amino- $1 \mathrm{H}-$ benzo[d]imidazol-1-yl)-5-(hydroxymethyl)cyclopentane-1,2-diol $\quad(( \pm)$-aristeromycin). The spectral data of synthesized ( \pm -aristeromycin via tert-Butyl-N-[4-[[tertbutyl(diphenyl)silyl]oxymethyl]-2,3-bis(4,4,5,5-tetramethyl-1,3,2-dioxaborolan-2-

yl)cyclopentyl]carbamate (7) was in accordance with the literature. ${ }^{8}$ Diastereoselectivity was obtained from analysis of the crude reaction mixture by ${ }^{13} \mathrm{C}$ NMR, and was determined to be 13:1. The stereoisomers were unable to be separated by silica gel chromatography.

\section{Crude reaction $\left({ }^{13} \mathrm{C}\right)$}
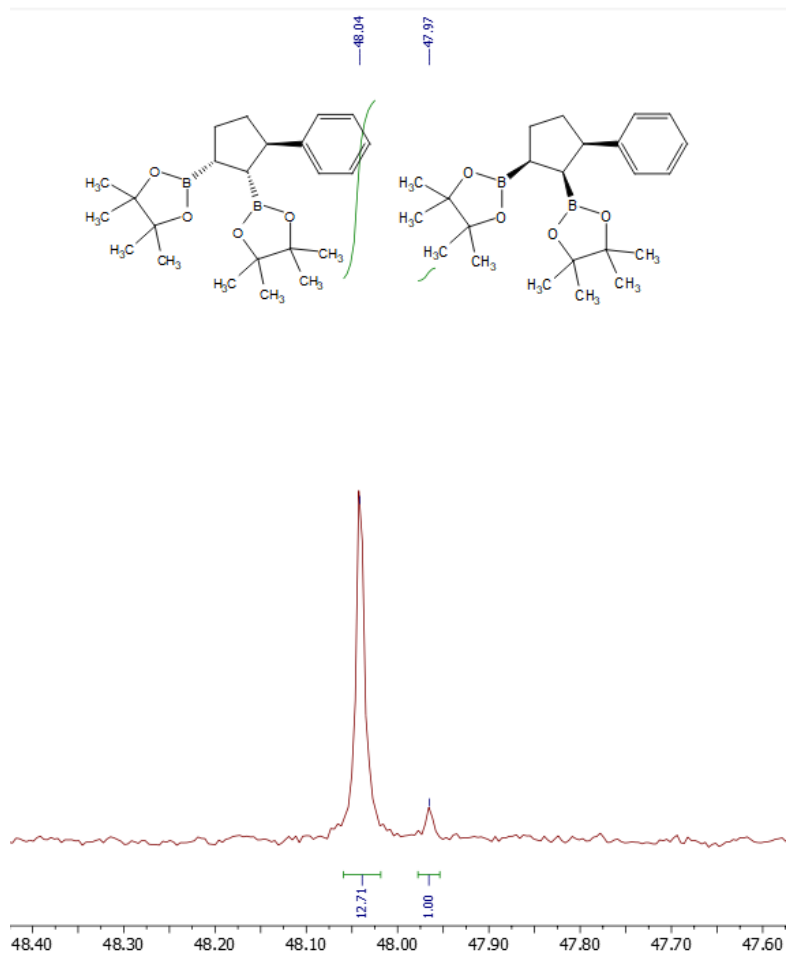


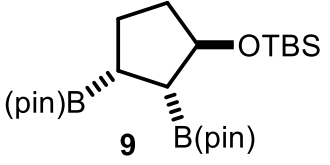

2,3-Bis(4,4,5,5-tetramethyl-1,3,2-dioxaborolan-2yl)cyclopentyl)oxy)(tert-butyl)dimethylsilane (9): The reaction was performed according to the general procedure (method 1) with tertbutyl(cyclopent-2-en-1-yloxy)dimethylsilane $(39.7 \mathrm{mg}, 0.20 \mathrm{mmol})$, bis(pinacolato)diboron (61.0 mg, $0.240 \mathrm{mmol}, 1.2$ equiv.), tris(dibenzylideneacetone)platinum(0) $(0.9 \mathrm{mg}, 1.00 \mu \mathrm{mol}, 0.5 \%)$ and toluene $(0.60 \mathrm{~mL})$. The reaction was allowed to stir for six hours at $50{ }^{\circ} \mathrm{C}$, and the reaction was then concentrated under reduced pressure. The crude reaction mixture was purified with the use of silica gel chromatography (3\% ethyl acetate in hexanes, stained in CAM) to afford a clear oil $(75.1 \mathrm{mg}, 83 \%$ yield $) .{ }^{1} \mathrm{H}\left(600 \mathrm{MHz}, \mathrm{CDCl}_{3}\right) \delta 4.34(\mathrm{dt}, J=$ 4.9, $2.5 \mathrm{~Hz}, 1 \mathrm{H}), 1.83$ (dddd, $J=20.6,15.2,10.1,5.9 \mathrm{~Hz}, 2 \mathrm{H}), 1.72(\mathrm{q}, J=8.6 \mathrm{~Hz}, 1 \mathrm{H}), 1.63-$ $1.54(\mathrm{~m}, 1 \mathrm{H}), 1.52-1.47(\mathrm{~m}, 2 \mathrm{H}), 1.24(\mathrm{~s}, 12 \mathrm{H}), 1.21(\mathrm{~d}, J=2.3 \mathrm{~Hz}, 12 \mathrm{H}), 0.85(\mathrm{~s}, 9 \mathrm{H}), 0.03(\mathrm{~s}$, $6 \mathrm{H}) .{ }^{13} \mathrm{C} \mathrm{NMR}\left(151 \mathrm{MHz}, \mathrm{CDCl}_{3}\right) \delta 82.92,82.88,76.8,36.4,26.2,26.1,25.00,24.97,24.9,24.8$, $18.2,-4.5,-4.6$. (Due to the quadrupolar nature of boron, the carbon adjacent to boron was not detectable.) ${ }^{11} \mathrm{~B}$ NMR $\left(160 \mathrm{MHz}, \mathrm{CDCl}_{3}\right) \delta$ 35.18. IR (neat) $v_{\max } 2977(\mathrm{~m}), 2956(\mathrm{~m}), 2929(\mathrm{~m})$, 2856 (m), 1471 (w), 1463 (m), 1409 (w), 1377 (s), 1370 (s), 1311 (s), 1251 (w), 1141 (s), 1049 (m), $978(\mathrm{w}), 937(\mathrm{w}), 858(\mathrm{~m}), 834(\mathrm{~s}), 773(\mathrm{~m}), 731(\mathrm{w}), 667(\mathrm{w}), 578(\mathrm{w}) \mathrm{cm}^{-1}$. HRMS (DART + ) $\mathrm{m} / \mathrm{z}:[\mathrm{M}+\mathrm{H}]^{+}$Calcd for $\mathrm{C}_{23} \mathrm{H}_{47} \mathrm{~B}_{2} \mathrm{O}_{5} \mathrm{Si}$ 453.3374; Found 453.3380.

\section{Analysis of Stereochemistry:}

The relative configuration was determined via the total synthesis of 3-(4-amino- $1 \mathrm{H}-$ benzo[d]imidazol-1-yl)-5-(hydroxymethyl)cyclopentane-1,2-diol $\quad(( \pm)$-aristeromycin). The spectral data of synthesized $( \pm)$-aristeromycin via tert-Butyl-N-[4-[[tertbutyl(diphenyl)silyl]oxymethyl]-2,3-bis(4,4,5,5-tetramethyl-1,3,2-dioxaborolan-2-

yl)cyclopentyl]carbamate (7) was in accordance with the literature. ${ }^{8}$ Diastereoselectivity was obtained from analysis of the crude reaction mixture by ${ }^{13} \mathrm{C}$ NMR, and determined to be $>20: 1$.

\section{Crude reaction $\left({ }^{13} \mathrm{C}\right)$ :}
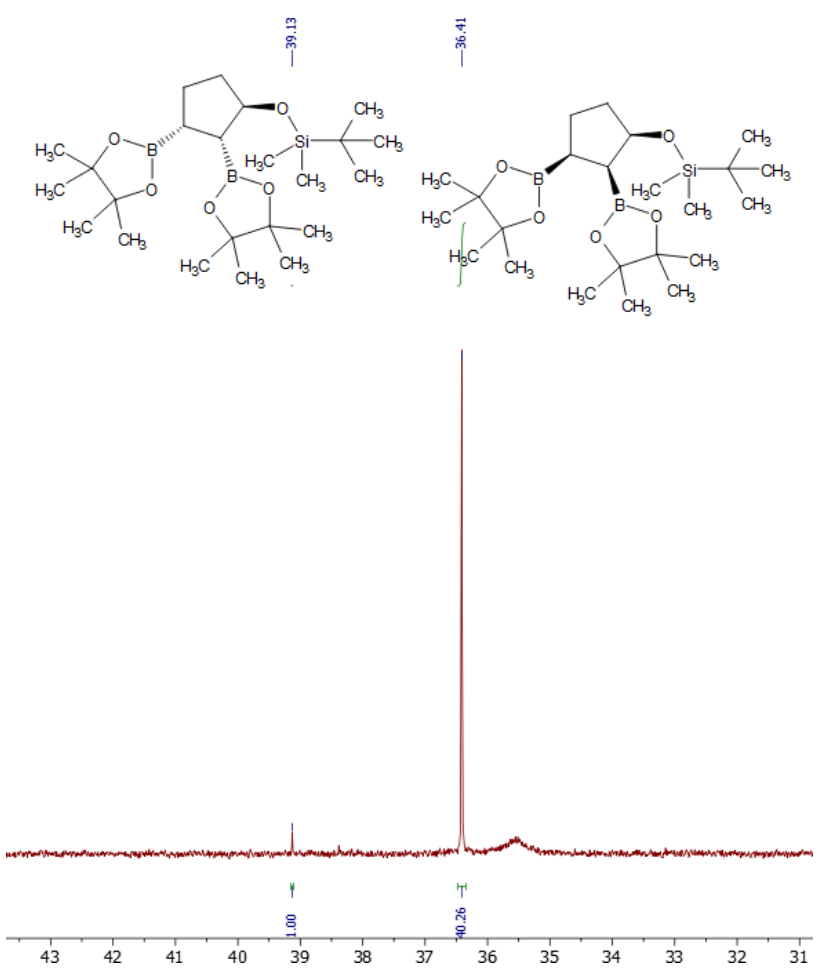


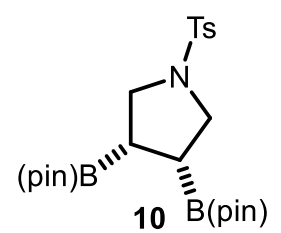

pyrrolidine (10): The reaction was performed according to the general procedure (method 1) with 1-tosyl-2,5-dihydro-1H-pyrrole $(44.7 \mathrm{mg}, 0.20$ mmol), bis(pinacolato)diboron (61.0 $\mathrm{mg}, \quad 0.240 \mathrm{mmol}, 1.2$ equiv.), tris(dibenzylideneacetone)platinum(0) $(0.9 \mathrm{mg}, 1.00 \mu \mathrm{mol}, 0.5 \%)$ and toluene concentrated under reduced pressure. The crude reaction mixture was purified with the use of silica gel chromatography (15\% ethyl acetate in hexanes, stained in CAM) to afford a white solid (70.7 $\mathrm{mg}, 74 \%$ yield). ${ }^{1} \mathrm{H}\left(600 \mathrm{MHz}, \mathrm{CDCl}_{3}\right) \delta 7.73(\mathrm{~d}, J=7.3 \mathrm{~Hz}, 2 \mathrm{H}), 7.28(\mathrm{~d}, J=7.3 \mathrm{~Hz}, 2 \mathrm{H}), 3.37$ $(\mathrm{dd}, J=9.2,5.3 \mathrm{~Hz}, 2 \mathrm{H}), 3.31(\mathrm{dd}, J=9.2,5.3 \mathrm{~Hz}, 2 \mathrm{H}), 2.40(\mathrm{~s}, 3 \mathrm{H}), 1.62(\mathrm{p}, J=6.8 \mathrm{~Hz}, 2 \mathrm{H})$, $1.16(\mathrm{~d}, J=9.2 \mathrm{~Hz}, 24 \mathrm{H}) .{ }^{13} \mathrm{C} \mathrm{NMR}\left(151 \mathrm{MHz}, \mathrm{CDCl}_{3}\right) \delta 142.8,134.9,129.5,127.6,83.6,50.2$, 24.8, 24.7, 21.5. (Due to the quadrupolar nature of boron, the carbon adjacent to boron was not detectable.) ${ }^{11} \mathrm{~B}$ NMR $\left(160 \mathrm{MHz}, \mathrm{CDCl}_{3}\right) \delta 33.89$. IR (neat) $v_{\max } 2978(\mathrm{br}), 1598(\mathrm{w}), 1418(\mathrm{w})$, 1381 (s), 1324 (s), 1261 (w), $1235(\mathrm{w}), 1214(\mathrm{w}), 1140(\mathrm{~s}), 1111(\mathrm{~m}), 1040(\mathrm{~m}), 1016(\mathrm{w}), 973$ (m), $917(\mathrm{w}), 872(\mathrm{w}), 857(\mathrm{~m}), 816(\mathrm{w}), 731(\mathrm{~m}), 714(\mathrm{~m}), 662(\mathrm{~s}), 595(\mathrm{~s}), 548(\mathrm{~s}) \mathrm{cm}^{-1}$. HRMS $(\mathrm{DART}+) \mathrm{m} / \mathrm{z}:[\mathrm{M}+\mathrm{H}]^{+}$Calcd for $\mathrm{C}_{23} \mathrm{H}_{38} \mathrm{~B}_{2} \mathrm{NO}_{6} \mathrm{~S}$ 478.2601; Found 478.2621.

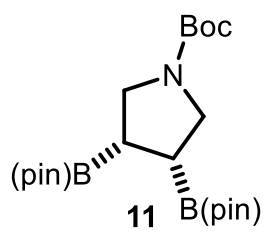

tert-Butyl-(cis)-3,4-bis(4,4,5,5-tetramethyl-1,3,2-dioxaborolan-2yl)pyrrolidine-1-carboxylate (11): The reaction was performed according to the general procedure (method 1) with tert-butyl 2,5-dihydro-1H-pyrrole-1carboxylate $(33.8 \mathrm{mg}, 0.20 \mathrm{mmol})$, bis(pinacolato)diboron $(61.0 \mathrm{mg}, 0.240$ mmol, 1.2 equiv.), tris(dibenzylideneacetone)platinum(0) $(0.9 \mathrm{mg}, 1.00 \mu \mathrm{mol}$, $0.5 \%)$ and toluene $(0.60 \mathrm{~mL})$. The reaction was allowed to stir for six hours at $50{ }^{\circ} \mathrm{C}$, and the reaction was then concentrated under reduced pressure. The crude reaction mixture was purified with the use of silica gel chromatography (5\% ethyl acetate in hexanes, stained in CAM) to afford a clear, colorless oil (41.5 mg, 49\% yield). ${ }^{1} \mathrm{H}$ NMR $\left(600 \mathrm{MHz}, \mathrm{CDCl}_{3}\right) \delta 3.47$ (s (minor rotamer), $1 \mathrm{H}), 3.34$ (s (major rotamer), 3H), 1.66 (s, 2H), 1.42 (s, 9H), 1.21 (s, 24H). ${ }^{13} \mathrm{C}$ NMR $(151 \mathrm{MHz}$, $\left.\mathrm{CDCl}_{3}\right) \delta 154.8,83.5,78.7,48.5,28.7,24.9$. (Due to the quadrupolar nature of boron, the carbon adjacent to boron was not detectable.) ${ }^{11} \mathrm{~B}$ NMR $\left(160 \mathrm{MHz}, \mathrm{CDCl}_{3}\right) \delta 34.40$. IR (neat) $v_{\max } 2976$ (m), 2931 (w), 1694 (s), 1475 (w), 1455 (w), 1378 (s), 1323 (s), 1257 (w), 1227 (w), 1145 (s), 1109 (m), 1008 (w), 975 (m), 859 (m), 771 (w), 771 (w), 703 (w), 675 (w), 579 (w). HRMS (DART+) m/z: $[\mathrm{M}+\mathrm{H}]^{+}$Calcd for $\mathrm{C}_{21} \mathrm{H}_{40} \mathrm{~B}_{2} \mathrm{NO}_{6}$ 424.3036; Found 424.3052 .

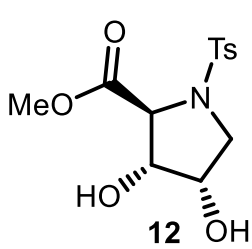

Methyl (2S,3R,4S)-3,4-dihydroxy-1-tosylpyrrolidine-2-carboxylate (12): The reaction was performed according to the general procedure (method 1) with methyl (S)-1-tosyl-2,5-dihydro-1H-pyrrole-2-carboxylate ( $56.3 \mathrm{mg}, 0.20 \mathrm{mmol}$ ), bis(pinacolato)diboron $\quad(61.0 \quad \mathrm{mg}, \quad 0.240 \mathrm{mmol}, \quad 1.2$ equiv.), tris(dibenzylideneacetone)platinum(0) $(0.9 \mathrm{mg}, 1.00 \mu \mathrm{mol}, 0.5 \%)$ and toluene $(0.60 \mathrm{~mL})$. The reaction was allowed to stir for six hours at $50{ }^{\circ} \mathrm{C}$, and the reaction was then concentrated under reduced pressure. Due to co-elution of the diboration product with starting alkene (S-10), the diboration product was oxidized. To the crude reaction mixture in a 2 dram vial equipped with a stir bar was added tetrahydrofuran $(1.00 \mathrm{~mL})$, and $\mathrm{pH}=7$ buffer $(1.00$ $\mathrm{mL}$ ). The reaction was then brought to $0{ }^{\circ} \mathrm{C}$ and to it was added hydrogen peroxide (35\% aq. Solution, $0.500 \mathrm{~mL}$ ). The reaction was then allowed to warm to room temperature and stirred for three hours The reaction was then cooled to $0{ }^{\circ} \mathrm{C}$ and to it was added saturated sodium thiosulfate dropwise $(1.00 \mathrm{~mL})$. To the reaction was then added ethyl acetate $(5 \mathrm{~mL})$, and the layers were 
separated. The aqueous layer was then washed an additional two times with ethyl acetate $(2 \times 5$ $\mathrm{mL}$ ). The organic layers were then combined, dried with $\mathrm{Na}_{2} \mathrm{SO}_{4}$, filtered, and concentrated under reduced pressure. The crude reaction mixture was then purified with the use of silica gel chromatography (40-50\% ethyl acetate in hexanes, stained in CAM) to afford a clear, colorless oil ( $22.1 \mathrm{mg}, 35 \%$ yield). Due to the presence of pinacol as an inseparable impurity, the yield was determined by integration via ${ }^{1} \mathrm{H}$ NMR. ${ }^{1} \mathrm{H}\left(500 \mathrm{MHz}, \mathrm{CDCl}_{3}\right) \delta 7.79(\mathrm{~d}, J=8.2 \mathrm{~Hz}, 2 \mathrm{H}), 7.31(\mathrm{~d}$, $J=8.2 \mathrm{~Hz}, 2 \mathrm{H}), 4.33-4.25(\mathrm{~m}, 2 \mathrm{H}), 4.14(\mathrm{~d}, J=4.5 \mathrm{~Hz}, 1 \mathrm{H}), 3.78(\mathrm{~s}, 3 \mathrm{H}), 3.64(\mathrm{dd}, J=10.8,4.5$ $\mathrm{Hz}, 1 \mathrm{H}), 3.32$ (dd, $J=10.8,4.5 \mathrm{~Hz}, 1 \mathrm{H}), 3.13(\mathrm{~s}(\mathrm{br}), 1 \mathrm{H}), 2.78(\mathrm{~s}(\mathrm{br}), 1 \mathrm{H}), 2.42$ (s, 3H) (Pinacol was present as an inseparable impurity at $1.23 \mathrm{ppm}(\mathrm{s})) .{ }^{13} \mathrm{C} \mathrm{NMR}\left(151 \mathrm{MHz}, \mathrm{CDCl}_{3}\right) \delta 171.4$, 144.2, 134.2, 129.8, 128.0, 75.8, 70.6, 65.7, 53.0, 52.3, 21.7. IR (neat) $v_{\max } 3484$ (br), 2926 (w), $1736(\mathrm{~s}), 1598(\mathrm{w}), 1494(\mathrm{w}), 1439(\mathrm{~m}), 1336(\mathrm{~m}), 1289(\mathrm{w}), 1204(\mathrm{w}), 1159(\mathrm{~s}), 1090(\mathrm{~m}), 886$ $(\mathrm{w}), 816(\mathrm{~m}), 756(\mathrm{w}), 707(\mathrm{w}), 665(\mathrm{~s}), 580(\mathrm{~m}), 549(\mathrm{~s}) \mathrm{cm}^{-1}$. HRMS (DART+) m/z: [M+H] Calcd for $\mathrm{C}_{13} \mathrm{H}_{18} \mathrm{NO}_{6} \mathrm{~S} 316.0849$; Found 316.0854 .

\section{Analysis of stereochemistry:}

The relative configuration was determined by analogy via the total synthesis of 3-(4-amino- $1 \mathrm{H}-$ benzo[d]imidazol-1-yl)-5-(hydroxymethyl)cyclopentane-1,2-diol $\quad( \pm$-aristeromycin). The spectral data of synthesized $( \pm)$-aristeromycin via tert-Butyl-N-[4-[[tertbutyl(diphenyl)silyl]oxymethyl]-2,3-bis(4,4,5,5-tetramethyl-1,3,2-dioxaborolan-2yl)cyclopentyl]carbamate (7) was in accordance with the literature. ${ }^{8}$ The diastereoselectivity was determined to be 7:1 by ${ }^{1} \mathrm{H}$ and ${ }^{13} \mathrm{C}$ NMR. The diastereomers were an inseparable mixture.

${ }^{1}$ H NMR
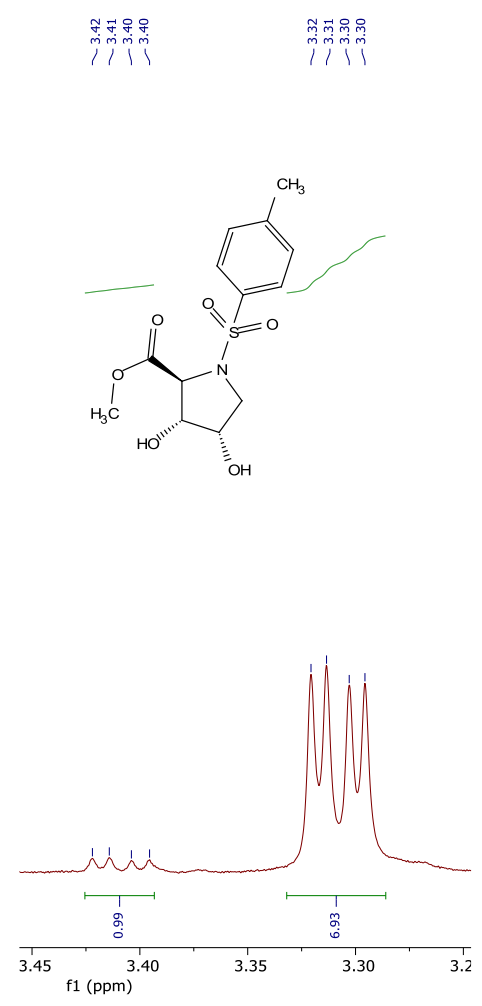

${ }^{13}$ C NMR
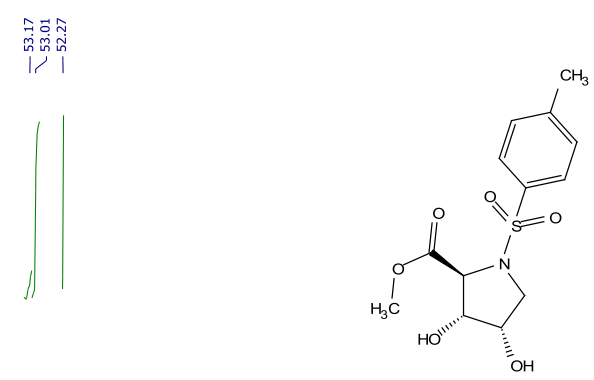

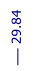

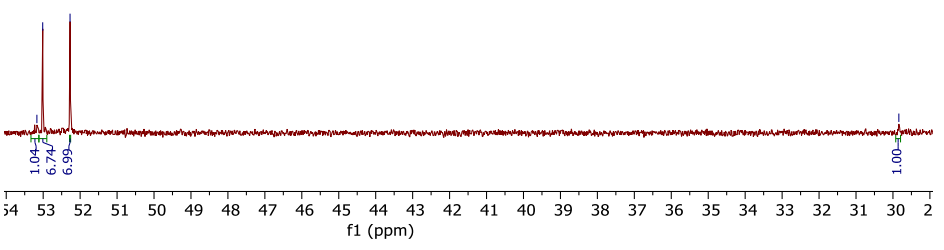




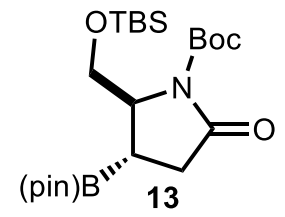

tert-Butyl-(2S,3S)-2-(((tert-butyldimethylsilyl)oxy)methyl)-5-oxo-3-
$(4,4,5,5$-tetramethyl-1,3,2-dioxaborolan-2-yl)pyrrolidine-1-carboxylate (13): The reaction was performed according to the general procedure with tertbutyl-(2S)-2-[[tert-butyl(dimethyl)silyl] oxymethyl]-5-oxo-2H-pyrrole-1carboxylate $(74.1 \mathrm{mg}, 0.20 \mathrm{mmol})$, bis(pinacolato)diboron $(61.0 \mathrm{mg}, 0.240$ mmol, 1.2 equiv.), tris(dibenzylideneacetone)platinum(0) $(0.9 \mathrm{mg}, 1.00 \mu \mathrm{mol}, 0.5 \%)$ and toluene $(0.60 \mathrm{~mL})$. The reaction was allowed to stir for six hours at $50{ }^{\circ} \mathrm{C}$, and then concentrated under reduced pressure. The crude reaction mixture was then purified with the use of silica gel chromatography (15\% ethyl acetate in hexanes, stained in CAM), to yield a clear, colorless oil (44.6 mg, 49\% yield). ${ }^{1} \mathrm{H}$ NMR $\left(600 \mathrm{MHz}, \mathrm{CDCl}_{3}\right) \delta 4.19$ (q, $\left.J=3.5 \mathrm{~Hz}, 1 \mathrm{H}\right), 3.98$ (dd, $J=10.4$, $3.5 \mathrm{~Hz}, 1 \mathrm{H}), 3.64(\mathrm{dd}, J=10.4,2.1 \mathrm{~Hz}, 1 \mathrm{H}), 2.77(\mathrm{dd}, J=17.6,11.3 \mathrm{~Hz}, 1 \mathrm{H}), 2.45(\mathrm{dd}, J=17.6$, $4.7 \mathrm{~Hz}, 1 \mathrm{H}), 1.78(\mathrm{dt}, J=11.3,4.7 \mathrm{~Hz}, 1 \mathrm{H}), 1.52(\mathrm{~s}, 9 \mathrm{H}), 1.25(\mathrm{~d}, J=19.6 \mathrm{~Hz}, 12 \mathrm{H}), 0.86(\mathrm{~s}, 9 \mathrm{H})$, $0.02(\mathrm{~d}, J=6.5 \mathrm{~Hz}, 6 \mathrm{H}) .{ }^{13} \mathrm{C} \mathrm{NMR}\left(151 \mathrm{MHz}, \mathrm{CDCl}_{3}\right) \delta 175.2,150.3,84.1,82.7,64.6,60.8,34.2$, $28.2,26.0,24.8,24.7,18.3,-5.37,-5.42$. (Due to the quadrupolar nature of boron, the carbon adjacent to boron was not detectable.) ${ }^{11} \mathrm{~B} \mathrm{NMR}\left(160 \mathrm{MHz}, \mathrm{CDCl}_{3}\right) \delta 34.93$.

IR (neat) $v_{\max } 3464(\mathrm{br}), 2978(\mathrm{~m}), 2930(\mathrm{~m}), 2857(\mathrm{w}), 1786(\mathrm{~m}), 1750(\mathrm{~m}), 1713(\mathrm{~s}), 1472(\mathrm{~m})$, 1367 (m), 1328 (m), 1305 (s), 1254 (m), 1213 (w), 1142 (s), 1116 (m), 1028 (w), 1008 (w), 996 (w), 879 (w), 836 (s), 777 (s), 748 (w), 675 (w), 579 (w) $\mathrm{cm}^{-1}$. HRMS (DART+) m/z: [M+H] Calcd for $\mathrm{C}_{22} \mathrm{H}_{43} \mathrm{BNO}_{6} \mathrm{Si}$ 456.2947; Found 456.2931.

\section{Analysis of Stereochemistry:}

The relative configuration was determined by analogy via the total synthesis of 3-(4-amino- $1 \mathrm{H}-$ benzo[d]imidazol-1-yl)-5-(hydroxymethyl)cyclopentane-1,2-diol $\quad(( \pm)$-aristeromycin). The spectral data of synthesized $( \pm)$-aristeromycin via tert-Butyl-N-[4-[[tertbutyl(diphenyl)silyl]oxymethyl]-2,3-bis(4,4,5,5-tetramethyl-1,3,2-dioxaborolan-2-

yl)cyclopentyl]carbamate (7) was in accordance with the literature. ${ }^{8}$ The diastereoselectivity was determined to be >20:1, as no additional diastereomer could be detected by ${ }^{1} \mathrm{H}$ and ${ }^{13} \mathrm{C}$ NMR.

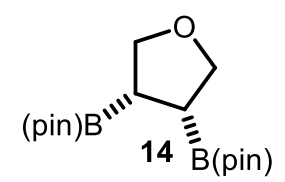

(Cis)-3,4-bis(4,4,5,5-tetramethyl-1,3,2-dioxaborolan-2-yl)tetrahydrofuran (14): The reaction was performed according to the general procedure with 2,5dihydrofuran (14.0 mg, $0.20 \mathrm{mmol})$, bis(pinacolato)diboron $(61.0 \mathrm{mg}, 0.240$ mmol, 1.20 equiv.), tris(dibenzylideneacetone)platinum(0) $(0.900 \mathrm{mg}, 1.00$ $\mu \mathrm{mol}, 0.5 \%)$ and toluene $(0.60 \mathrm{~mL})$. The reaction was allowed to stir for six hours at $50{ }^{\circ} \mathrm{C}$, and then concentrated under reduced pressure. The crude reaction mixture was then purified with the use of silica gel chromatography (5\% ethyl acetate in hexanes, stained in CAM), to yield a clear, colorless oil (30.5 mg, 47\% yield). ${ }^{1} \mathrm{H}$ NMR $\left(600 \mathrm{MHz}, \mathrm{CDCl}_{3}\right) \delta 3.89(\mathrm{t}, \mathrm{J}=7.3 \mathrm{~Hz}, 2 \mathrm{H}), 3.78(\mathrm{t}$, $\mathrm{J}=7.1 \mathrm{~Hz}, 2 \mathrm{H}), 1.76(\mathrm{p}, \mathrm{J}=7.6 \mathrm{~Hz}, 2 \mathrm{H}), 1.25(\mathrm{~s}, 24 \mathrm{H}) .{ }^{13} \mathrm{C} \mathrm{NMR}\left(126 \mathrm{MHz}, \mathrm{CDCl}_{3}\right) \delta 83.3,70.4$, 24.7. (Due to the quadrupolar nature of boron, the carbon adjacent to boron was not detectable.) ${ }^{11} \mathrm{~B}$ NMR $\left(160 \mathrm{MHz}, \mathrm{CDCl}_{3}\right) \delta$ 34.15. IR (neat) $v_{\max } 3393$ (br), $2978(\mathrm{~m}), 1728$ (br), $1474(\mathrm{~m})$, $1453(\mathrm{~m}), 1380(\mathrm{~s}), 1372(\mathrm{~s}), 1325(\mathrm{~s}), 1272(\mathrm{w}), 1215(\mathrm{~m}), 1141(\mathrm{~s}), 1008(\mathrm{~m}), 982(\mathrm{~m}), 926(\mathrm{w})$, $926(\mathrm{w}), 926(\mathrm{w}), 851(\mathrm{~s}), 729(\mathrm{w}), 699(\mathrm{w}), 674(\mathrm{~m}), 729(\mathrm{w}), 699(\mathrm{w}), 674(\mathrm{~s}), 623(\mathrm{w}), 604(\mathrm{w})$, $597(\mathrm{w}), 577(\mathrm{w}) \mathrm{cm}^{-1}$. HRMS (DART+) $\mathrm{m} / \mathrm{z}$ : $[\mathrm{M}+\mathrm{H}]^{+}$Calcd for $\mathrm{C}_{16} \mathrm{H}_{31} \mathrm{~B}_{2} \mathrm{O}_{5}$ 325.2352; Found 325.2352 . 


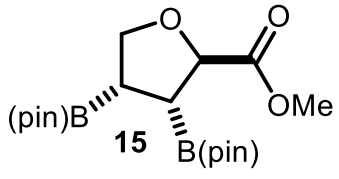

Methyl-3,4-bis(4,4,5,5-tetramethyl-1,3,2-dioxaborolan-2yl)tetrahydrofuran-2-carboxylate (15): The reaction was performed according to the general procedure with methyl 2,5-dihydrofuran-2carboxylate $(25.6 \mathrm{mg}, 0.20 \mathrm{mmol})$, bis(pinacolato)diboron $(61.0 \mathrm{mg}, 0.240$ mmol, 1.2 equiv.), tris(dibenzylideneacetone)platinum(0) $(0.9 \mathrm{mg}, 1.00 \mu \mathrm{mol}, 0.5 \%)$ and toluene $(0.60 \mathrm{~mL})$. The reaction was allowed to stir for six hours at $50{ }^{\circ} \mathrm{C}$, and then concentrated under reduced pressure. The crude reaction mixture was then purified with the use of silica gel chromatography (10-15\% ethyl acetate in hexanes, stained in CAM), to yield a clear, colorless oil (37.4 mg, 49\%). ${ }^{1} \mathrm{H}$ NMR (500 MHz, $\left.\mathrm{CDCl}_{3}\right) \delta 4.55(\mathrm{~d}, J=4.6 \mathrm{~Hz}, 1 \mathrm{H}), 4.13(\mathrm{t}, J=7.7 \mathrm{~Hz}, 1 \mathrm{H})$, $3.88(\mathrm{t}, J=7.7 \mathrm{~Hz}, 1 \mathrm{H}), 3.70(\mathrm{~s}, 3 \mathrm{H}), 1.99(\mathrm{dd}, J=7.7,4.6 \mathrm{~Hz}, 1 \mathrm{H}), 1.84(\mathrm{q}, J=7.7 \mathrm{~Hz}, 1 \mathrm{H}), 1.25$ (s, 24H). ${ }^{13} \mathrm{C}$ NMR $\left(151 \mathrm{MHz}, \mathrm{CDCl}_{3}\right) \delta 174.3,84.0,83.7,79.1,72.0,52.0,25.1,25.0,24.9,24.7$. (Due to the quadrupolar nature of boron, the carbon adjacent to boron was not detectable.) ${ }^{11} \mathrm{~B}$ NMR $\left(160 \mathrm{MHz}, \mathrm{CDCl}_{3}\right) \delta$ 34.08. IR (neat) $v_{\max } 2978$ (m), 1749 (s), 1416 (m), 1380 (s), 1371 (s), 1323 9s), 1259 (m), 1212 (m), 1167 (s), 1140 (s), $1111(\mathrm{w}), 1083$ (w), $1006(\mathrm{w}), 970$ (m), 926 (w), $887(\mathrm{w}), 859(\mathrm{~m}), 851(\mathrm{~m}), 731(\mathrm{w}), 695(\mathrm{w}), 668(\mathrm{w}), 579(\mathrm{w}) \mathrm{cm}^{-1}$. HRMS (DART+) m/z: $[\mathrm{M}+\mathrm{H}]^{+}$Calcd for $\mathrm{C}_{18} \mathrm{H}_{33} \mathrm{~B}_{2} \mathrm{O}_{7}$ 383.2407; Found 383.2422.

\section{Analysis of Stereochemistry:}

The relative configuration was determined by analogy via the total synthesis of 3-(4-amino- $1 \mathrm{H}-$ benzo[d]imidazol-1-yl)-5-(hydroxymethyl)cyclopentane-1,2-diol (( $\quad$ )-aristeromycin). The spectral data of synthesized $( \pm)$-aristeromycin via tert-Butyl-N-[4-[[tertbutyl(diphenyl)silyl]oxymethyl]-2,3-bis(4,4,5,5-tetramethyl-1,3,2-dioxaborolan-2-

yl)cyclopentyl]carbamate (7) was in accordance with the literature. ${ }^{8}$ The diastereoselectivity was determined to be $9: 1$ by ${ }^{13} \mathrm{C}$ NMR. Both diastereomers were unable to be separated via silica gel chromatography.

${ }^{13}$ C NMR:
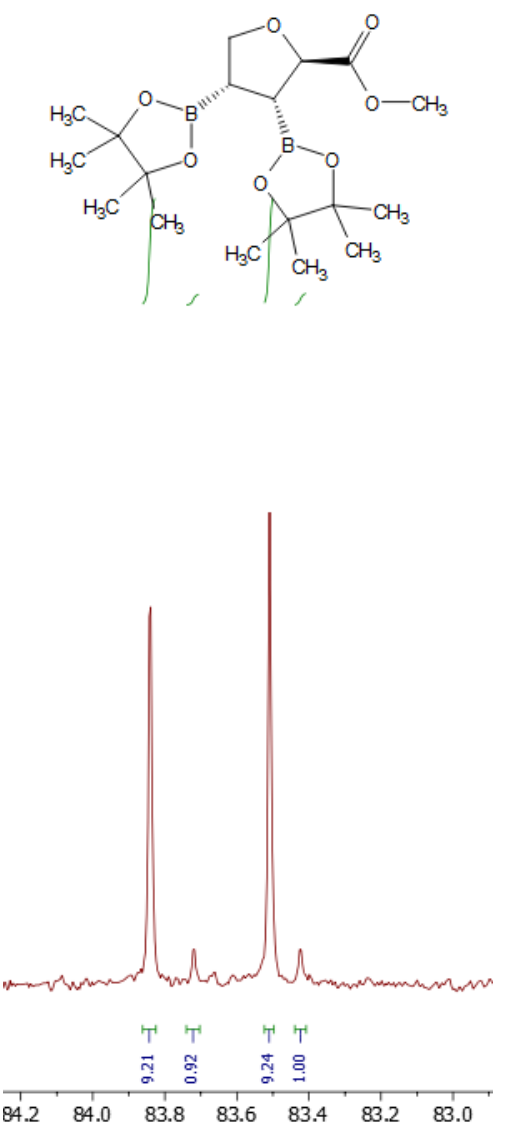


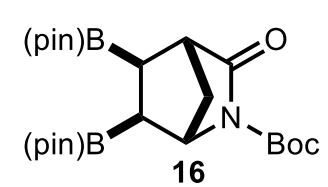

tert-Butyl-3-oxo-5,6-bis(4,4,5,5-tetramethyl-1,3,2-dioxaborolan-2-yl)-2azabicyclo[2.2.1] heptane-2-carboxylate (16): The reaction was performed according to the general procedure (method 1) with tert-butyl 2-oxo-3azabicyclo[2.2.1]hept-5-ene-3-carboxylate $\left(\begin{array}{llll}41.9 & \mathrm{mg}, & 0.20 & \mathrm{mmol}\end{array}\right)$, bis(pinacolto)diboron (61.0 $\mathrm{mg}, 0.240 \mathrm{mmol}, 1.2$ equiv.), tris(dibenzylideneacetone)platinum(0) $(0.9 \mathrm{mg}, 1.00 \mu \mathrm{mol}, 0.5 \%)$ and toluene $(0.60 \mathrm{~mL})$. The reaction was allowed to stir for six hours at $50{ }^{\circ} \mathrm{C}$, and was then concentrated under reduced pressure. The crude reaction mixture was purified with the use of silica gel chromatography (10\% ethyl acetate in hexanes, stained in CAM) to yield a white solid (67.6 mg, 73\% yield). ${ }^{1} \mathrm{H}$ NMR $\left(500 \mathrm{MHz}, \mathrm{CDCl}_{3}\right) \delta 4.48$ (q, $J=1.8 \mathrm{~Hz}$, $1 \mathrm{H}), 2.84(\mathrm{~s}, 1 \mathrm{H}), 1.79(\mathrm{dt}, J=10.1,1.8 \mathrm{~Hz}, 1 \mathrm{H}) 1.67-1.61(\mathrm{~m}, 3 \mathrm{H}), 1.50(\mathrm{~s}, 9 \mathrm{H}), 1.23(\mathrm{~d}, J=4.9$ $\mathrm{Hz}, 24 \mathrm{H}) .{ }^{13} \mathrm{C}$ NMR $\left(126 \mathrm{MHz}, \mathrm{CDCl}_{3}\right) \delta 176.3,149.7,83.7,83.4,82.4,61.3,48.9,37.3,28.2$, 25.0, 24.9 (2), 24.8. (Due to the quadrupolar nature of boron, the carbon adjacent to boron was not detectable.) ${ }^{11} \mathrm{~B}$ NMR $\left(160 \mathrm{MHz}, \mathrm{CDCl}_{3}\right) \delta$ 34.12. IR (neat) $v_{\max } 2978(\mathrm{~m}), 2250$ (br), $1786(\mathrm{~s})$, 1759 (s), 1710 (s), 1471 (w), 1407 (w), 1336 (s), 1346 (s), 1308 (s), 1256 (w), 1230 (w), 1137 (s), 1108 (w), 1035 (w), $1201(w), 983(w), 955(w), 940(w), 917(w), 854(m), 799(w), 778(w), 731$ (m), $670(\mathrm{w}), 646(\mathrm{w}) \mathrm{cm}^{-1}$. HRMS (DART+) m/z: $[\mathrm{M}+\mathrm{H}]^{+}$Calcd for $\mathrm{C}_{23} \mathrm{H}_{40} \mathrm{~B}_{2} \mathrm{NO}_{7} 464.2985$; Found 464.2994. A crystal for analysis by X-ray crystallography was prepared by evaporation. Purified compound 16 was dissolved in a solution of 3:1 hexanes:dichloromethane by heating. The solution was then allowed to cool to room temperature, and evaporation of the solvent system provided a crystal of compound $\mathbf{1 6}$ suitable for analysis.

\section{Analysis of Stereochemistry:}

The relative configuration was determined by X-ray crystallography. tert-Butyl-3-oxo-5,6bis(4,4,5,5-tetramethyl-1,3,2-dioxaborolan-2-yl)-2-azabicyclo[2.2.1]heptane-2-carboxylate (16) was recrystallized from hexanes:dichloromethane, and indicated an exo addition product. The diastereoselectivity was determined to be $>20: 1$, as no additional diastereomer could be detected by ${ }^{1} \mathrm{H}$ and ${ }^{13} \mathrm{C}$ NMR.

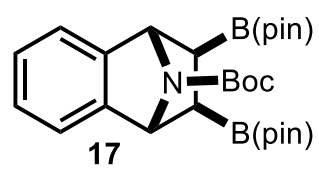

tert-Butyl-2,3-bis(4,4,5,5-tetramethyl-1,3,2-dioxaborolan-2-yl)-1,2,3,4tetrahydro-1,4-epiminonaphthalene-9-carboxylate (17): The reaction was performed according to the general procedure (method 1) with tert-butyl 15azatricycloundeca-3(5),4(6),7,9-tetraene-15-carboxylate $(48.7 \mathrm{mg}, \quad 0.20$ $\mathrm{mmol})$, bis(pinacolato)diboron $\quad(61.0 \quad \mathrm{mg}, \quad 0.240 \quad \mathrm{mmol}, \quad 1.2$ equiv.), tris(dibenzylideneacetone)platinum(0) $(0.9 \mathrm{mg}, 1.00 \mu \mathrm{mol}, 0.5 \%)$ and toluene $(0.60 \mathrm{~mL})$. The reaction was allowed to stir for six hours at $50{ }^{\circ} \mathrm{C}$, and then concentrated under reduced pressure. The crude reaction mixture was purified with the use of silica gel chromatography (10\% ethyl acetate in hexanes, stained in CAM), to afford a clear oil that solidified in a freezer overnight (72.6 $\mathrm{mg}, 73 \%$ yield). ${ }^{1} \mathrm{H} \mathrm{NMR}\left(500 \mathrm{MHz}, \mathrm{CDCl}_{3}\right) \delta 7.22(\mathrm{~s}(\mathrm{br}), 2 \mathrm{H}), 7.10-7.03(\mathrm{~m}, 2 \mathrm{H}), 5.22(\mathrm{~s}, 2 \mathrm{H})$, $1.39(\mathrm{~s}, 9 \mathrm{H}), 1.29(\mathrm{~s}, 24 \mathrm{H}), 1.10(\mathrm{~d}, J=10.9 \mathrm{~Hz}, 2 \mathrm{H}) .{ }^{13} \mathrm{C} \mathrm{NMR}\left(151 \mathrm{MHz}, \mathrm{CDCl}_{3}\right) \delta 152.8,146.5$, 125.9, 119.2 (br), 118.5 (br), 83.7, 83.0, 79.0, 62.4 (br), 61.8 (br), 28.5, 24.9, 24.6. (Due to the quadrupolar nature of boron, the carbon adjacent to boron was not detectable.) ${ }^{11} \mathrm{~B}$ NMR (160 $\mathrm{MHz}, \mathrm{CDCl}_{3}$ ) $\delta$ 34.60. IR (neat) $v_{\max } 2977$ (w), 2929 (w), 1697 (s), 1406 (w), 1363 (s), 1328 (s), $1277(\mathrm{~m}), 1216(\mathrm{w}), 1164(\mathrm{~m}), 1141(\mathrm{~s}), 1092(\mathrm{~m}), 1010(\mathrm{w}), 967$ (w), $906(\mathrm{w}), 855(\mathrm{~m}), 750(\mathrm{~m})$, $732(\mathrm{~m}), 668(\mathrm{w}), 657(\mathrm{w}), 619(\mathrm{w}), 579(\mathrm{w}) \mathrm{cm}^{-1}$. HRMS (DART+) m/z: [M+H] $]^{+}$Calcd for $\mathrm{C}_{27} \mathrm{H}_{42} \mathrm{~B}_{2} \mathrm{NO}_{6}$ 498.3193; Found 498.3192. 


\section{Analysis of Stereochemistry:}

The relative configuration was determined by analogy. X-ray crystallography of tert-butyl-3-oxo5,6-bis(4,4,5,5-tetramethyl-1,3,2-dioxaborolan-2-yl)-2-azabicyclo[2.2.1] heptane-2-carboxylate (16) indicated an exo addition product. The diastereoselectivity was determined to be $>20: 1$, as no additional diastereomer could be detected by ${ }^{1} \mathrm{H}$ and ${ }^{13} \mathrm{C}$ NMR.

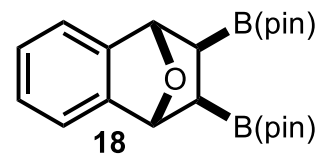

2,3-Bis(4,4,5,5-tetramethyl-1,3,2-dioxaborolan-2-yl)-1,2,3,4-tetrahydro1,4-epoxynaphthalene (18): The reaction was performed according to the general procedure (method 1) with 10-oxatricycloundeca-(2),1(3),4,6tetraene $(57.6 \mathrm{mg}, 0.400 \mathrm{mmol})$, bis(pinacolato)diboron $(122 \mathrm{mg}, 0.480$ mmol, 1.2 equiv.), tris(dibenzylideneacetone)platinum( 0 ) (1.8 $\mathrm{mg}, 2.00 \mu \mathrm{mol}, 0.5 \%)$ and toluene $(0.60 \mathrm{~mL})$. The reaction was allowed to stir for six hours at $50{ }^{\circ} \mathrm{C}$, and the reaction was then concentrated under reduced pressure. The crude reaction mixture was purified with the use of silica gel chromatography ( $10 \%$ ethyl acetate in hexanes, stained in CAM) to afford a colorless oil (39.8 $\mathrm{mg}, 25 \%){ }^{1} \mathrm{H}$ NMR $\left(500 \mathrm{MHz}, \mathrm{CDCl}_{3}\right) \delta 7.22(\mathrm{dd}, J=5.2,3.0 \mathrm{~Hz}, 2 \mathrm{H}), 7.10(\mathrm{dd}, J=5.2,3.0 \mathrm{~Hz}$, $2 \mathrm{H}), 5.44(\mathrm{~s}, 2 \mathrm{H}), 1.32(\mathrm{~d}, J=4.7 \mathrm{~Hz}, 24 \mathrm{H}), 1.21(\mathrm{~s}, 2 \mathrm{H}) .{ }^{13} \mathrm{C} \mathrm{NMR}\left(151 \mathrm{MHz}, \mathrm{CDCl}_{3}\right) \delta 146.5$, 126.2, 118.3, 83.8, 81.0, 25.1, 25.0. (Due to the quadrupolar nature of boron, the carbon adjacent to boron was not detectable.) ${ }^{11} \mathrm{~B}$ NMR $\left(160 \mathrm{MHz}, \mathrm{CDCl}_{3}\right) \delta 35.01$. IR (neat) $v_{\max } 2977(\mathrm{~m}), 2929$ (w), $1460(\mathrm{~m}), 1404(\mathrm{w}), 1362$ (s), $1318(\mathrm{~s}), 1274(\mathrm{w}), 1243(\mathrm{w}), 1220(\mathrm{~m}), 1139(\mathrm{~s}), 1108(\mathrm{w})$, $1012(\mathrm{~m}), 998(\mathrm{w}), 997(\mathrm{~m}), 909(\mathrm{~m}), 890(\mathrm{w}), 853(\mathrm{~s}), 757(\mathrm{~m}), 732(\mathrm{~m}), 712(\mathrm{w}), 667(\mathrm{w}), 618$ (w), $592(\mathrm{w}), 577(\mathrm{w}) \mathrm{cm}^{-1}$. HRMS (DART+) m/z: $\left[\mathrm{M}+\mathrm{NH}_{4}\right]^{+}$Calcd for $\mathrm{C}_{22} \mathrm{H}_{36} \mathrm{~B}_{2} \mathrm{NO}_{5} 416.2774$; Found 416.2790.

\section{Analysis of Stereochemistry:}

The relative configuration was determined via analogy. X-ray crystallography of tert-butyl-3-oxo5,6-bis(4,4,5,5-tetramethyl-1,3,2-dioxaborolan-2-yl)-2-azabicyclo[2.2.1] heptane-2-carboxylate (16) indicated an exo addition product. The diastereoselectivity was determined to be $>20: 1$, as no additional diastereomer could be detected by ${ }^{1} \mathrm{H}$ and ${ }^{13} \mathrm{C}$ NMR.

\section{Characterization of cyclic alkene diboration products (Method 2)}

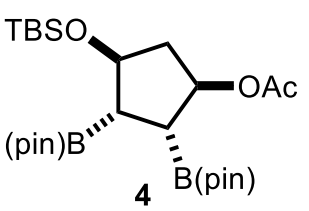
carbon $(7.8 \mathrm{mg}, 6.00 \mu \mathrm{mol}, 3.0 \%)$ and toluene $(0.60 \mathrm{~mL})$. The reaction vial was then sealed with a cap under air, and was allowed to stir for six hours at $50{ }^{\circ} \mathrm{C}$. The reaction was then filtered through a silica gel plug with diethyl ether and concentrated under reduced pressure. The crude reaction mixture was purified with the use of silica gel chromatography (5\% ethyl acetate in hexanes, stained in CAM) to yield a colorless oil that solidified into a white solid upon standing overnight $(91.8 \mathrm{mg}, 90 \%$ yield). The spectral data was in accordance with preparation of (4) by method 1 . 


\section{Analysis of Stereochemistry:}

The relative configuration was determined by analogy via the total synthesis of 9$\left[\left(1^{\prime} \mathrm{R}, 2^{\prime} \mathrm{S}, 3^{\prime} \mathrm{R}, 4^{\prime} \mathrm{R}\right)-\left[\left(2^{\prime}, 3^{\prime}\right.\right.\right.$-(Dihydroxy)-4'-(hydroxymethyl)cyclopentan-1'-yl]adenine (aristeromycin). The spectral data of synthesized aristeromycin via tert-Butyl-N-[4-[[tertbutyl(diphenyl)silyl]oxymethyl]-2,3-bis(4,4,5,5-tetramethyl-1,3,2-dioxaborolan-2yl)cyclopentyl]carbamate (7) was in accordance with the literature. ${ }^{8}$ The diastereoselectivity was determined to be $>20: 1$, as no additional diastereomer could be detected by ${ }^{1} \mathrm{H}$ and ${ }^{13} \mathrm{C}$ NMR.

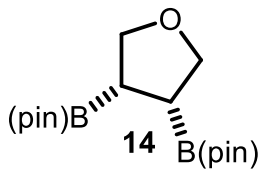

(Cis)-3,4-bis(4,4,5,5-tetramethyl-1,3,2-dioxaborolan-2-yl)tetrahydrofuran (14): The reaction was performed according to the general procedure (method 2) with 2,5-dihydrofuran $(14.0 \mathrm{mg}, 0.20 \mathrm{mmol})$, bis(pinacolato)diboron (102 $\mathrm{mg}, 0.400 \mathrm{mmol}, 2.0$ equiv.), $10 \%$ platinum on carbon $(7.8 \mathrm{mg}, 6.00 \mu \mathrm{mol}$, $3.0 \%)$ and toluene $(0.60 \mathrm{~mL})$. The reaction vial was then sealed with a cap under air, and was allowed to stir for six hours at $50{ }^{\circ} \mathrm{C}$. The reaction was then filtered through a silica gel plug with diethyl ether and concentrated under reduced pressure. The crude reaction mixture was purified with the use of silica gel chromatography (5\% ethyl acetate in hexanes, stained in CAM) to afford a colorless oil (32.4 mg, 50\% yield). The spectral data was in accordance with preparation of (14) by method 1 .

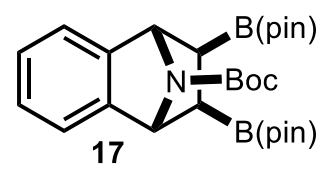

tert-butyl-2,3-bis(4,4,5,5-tetramethyl-1,3,2-dioxaborolan-2-yl)-1,2,3,4tetrahydro-1,4-epiminonaphthalene-9-carboxylate (17): The reaction was performed according to the general procedure (method 2) with tert-butyl 15azatricycloundeca-3(5),4(6),7,9-tetraene-15-carboxylate (48.7 $\mathrm{mg}, \quad 0.20$ mmol), bis(pinacolato)diboron (102 $\mathrm{mg}, 0.400 \mathrm{mmol}, 2.0$ equiv.), $10 \%$ platinum on carbon ( 7.8 $\mathrm{mg}, 6.00 \mu \mathrm{mol}, 3.0 \%)$ and toluene $(0.60 \mathrm{~mL})$. The reaction vial was then sealed with a cap under air, and was allowed to stir for six hours at $50{ }^{\circ} \mathrm{C}$. The reaction was then filtered through a silica gel plug with diethyl ether and concentrated under reduced pressure. The crude reaction mixture was purified with the use of silica gel chromatography (10\% ethyl acetate in hexanes, stained in CAM) to yield a colorless oil that solidified into a colorless solid upon standing overnight (48.7 $\mathrm{mg}, 49 \%$ yield). The spectral data was in accordance with preparation of (17) by method 1 .

\section{Analysis of Stereochemistry:}

The relative configuration was determined by analogy. X-ray crystallography of tert-butyl-3-oxo5,6-bis(4,4,5,5-tetramethyl-1,3,2-dioxaborolan-2-yl)-2-azabicyclo[2.2.1] heptane-2-carboxylate (16) indicated an exo addition product. The diastereoselectivity was determined to be $>20: 1$, as no additional diastereomer could be detected via ${ }^{1} \mathrm{H}$ and ${ }^{13} \mathrm{C}$ NMR. 


\section{Procedures and characterization of diboronate product functionalization}
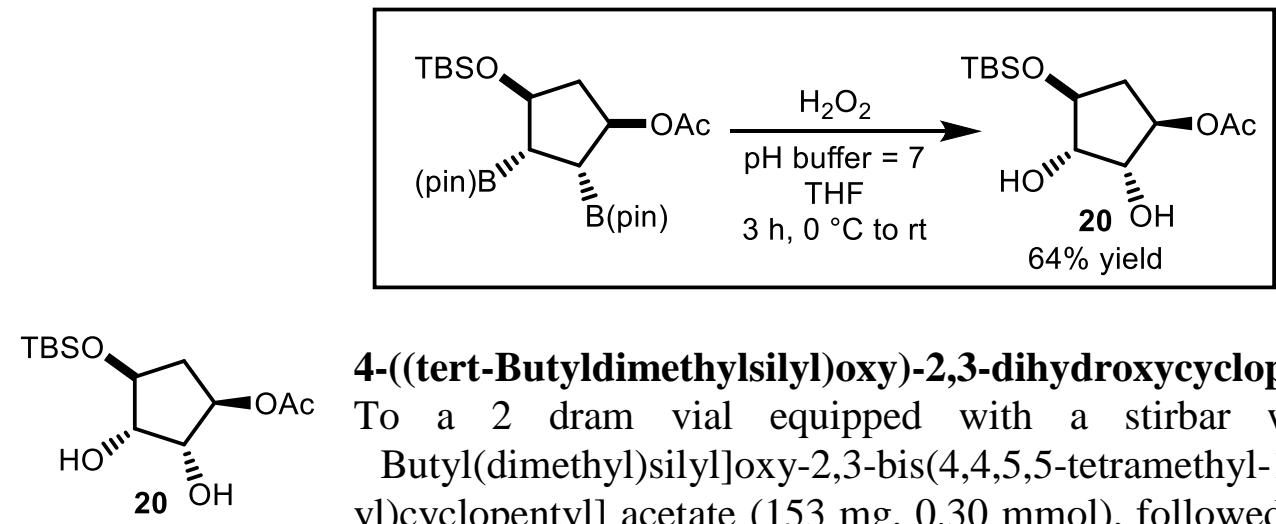

4-((tert-Butyldimethylsilyl)oxy)-2,3-dihydroxycyclopentyl acetate (20):

To a 2 dram vial equipped with a stirbar was added [4-[tert-

Butyl(dimethyl)silyl]oxy-2,3-bis(4,4,5,5-tetramethyl-1,3,2-dioxaborolan-2-

yl)cyclopentyl] acetate $(153 \mathrm{mg}, 0.30 \mathrm{mmol})$, followed by THF (1 mL) and $\mathrm{pH}$ buffer $(1 \mathrm{~mL}, \mathrm{pH}=7)$. The reaction was then cooled to $0{ }^{\circ} \mathrm{C}$ and to it was added $35 \% \mathrm{w} / \mathrm{w}$ hydrogen peroxide $(0.5 \mathrm{~mL})$ dropwise. The reaction was then warmed to room temperature and allowed to stir for three hours. The reaction was then cooled to $0{ }^{\circ} \mathrm{C}$ and quenched with sodium thiosulfate $(1 \mathrm{~mL})$ via dropwise addition. To the reaction was then added ethyl acetate $(5 \mathrm{~mL})$, and the layers were separated. The aqueous layer was then washed an additional two times with ethyl acetate $(2 \times 5 \mathrm{~mL})$. The organic layers were then combined, dried with sodium sulfate, filtered, and concentrate under reduced pressure. The crude reaction mixture was purified with the use of silica gel chromatography (10-45\% ethyl acetate in hexanes) to afford a colorless oil $(55.8 \mathrm{mg}, 64 \%$ yield). Due to the presence of pinacol as an inseparable impurity, the yield was determined by integration by ${ }^{1} \mathrm{H}$ NMR. ${ }^{1} \mathrm{H}$ NMR $\left(600 \mathrm{MHz}, \mathrm{CDCl}_{3}\right) \delta 4.82(\mathrm{dt}, J=9.4,4.8 \mathrm{~Hz}, 1 \mathrm{H}), 4.19(\mathrm{t}, J=$ $4.8 \mathrm{~Hz}, 1 \mathrm{H}), 4.11(\mathrm{dt}, J=5.8,2.9 \mathrm{~Hz}, 1 \mathrm{H}), 3.94-3.91(\mathrm{~m}, 1 \mathrm{H}), 3.62(\mathrm{~s}, 1 \mathrm{H}), 2.66(\mathrm{~s}, 1 \mathrm{H}), 2.61$ (ddd, $J=14.9,9.4,5.8 \mathrm{~Hz}, 1 \mathrm{H}), 2.10$ (s, 3H), 1.67 (ddt, $J=14.9,4.0 \mathrm{~Hz}, 1 \mathrm{H}), 0.88(\mathrm{~s}, 9 \mathrm{H}), 0.07$ (s, 6H). Pinacol was present as an impurity at $1.24 \mathrm{ppm} .{ }^{13} \mathrm{C}$ NMR $\left(151 \mathrm{MHz}, \mathrm{CDCl}_{3}\right) \delta 173.0,81.2,78.1$, 77.9, 75.3, 37.4, 25.8, 21.2, 18.1, -4.8, -4.7. IR (neat) $v_{\max } 3412$ (br), $2953(\mathrm{~m}), 2929(\mathrm{~m}), 2857$ (m), 1719 (s), 1472 (w), 1463 (w), 1362 (m), 1248 (s), 1067 (s), 938 (w), 863 (m), 836 (s), 803 (s), 776 (s), 665 (w), $612(\mathrm{w}), 589$ (w) $\mathrm{cm}^{-1}$. HRMS (DART+) m/z: [M+H] ${ }^{+}$Calcd for $\mathrm{C}_{13} \mathrm{H}_{27} \mathrm{O}_{5} \mathrm{Si}$ 291.1622; Found 291.1632.
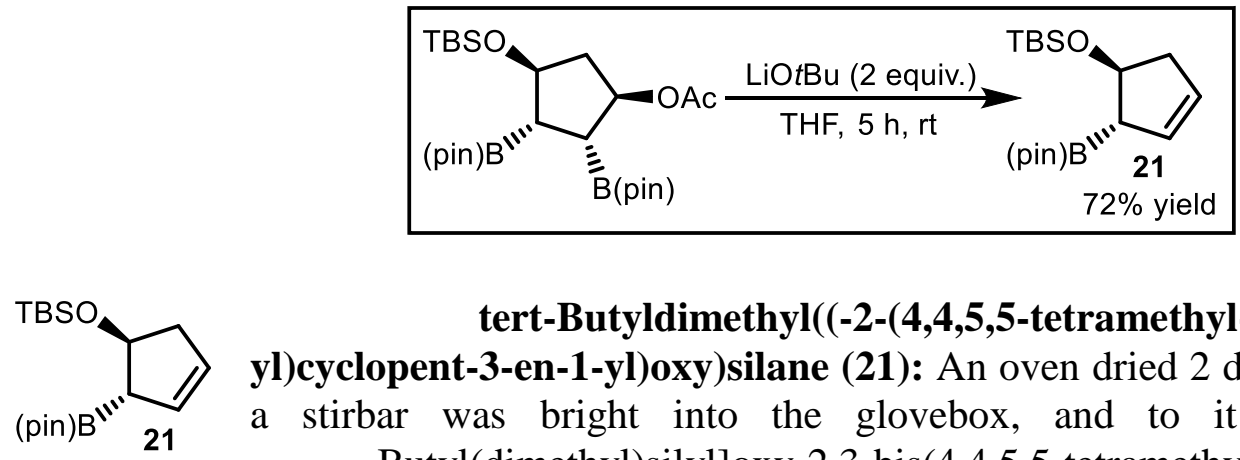

tert-Butyldimethyl((-2-(4,4,5,5-tetramethyl-1,3,2-dioxaborolan-2yl)cyclopent-3-en-1-yl)oxy)silane (21): An oven dried 2 dram vial equipped with a stirbar was bright into the glovebox, and to it was added [4-[tertButyl(dimethyl)silyl]oxy-2,3-bis(4,4,5,5-tetramethyl-1,3,2-dioxaborolan-2yl)cyclopentyl] acetate $(204 \mathrm{mg}, 0.40 \mathrm{mmol})$ and THF $(1.3 \mathrm{~mL})$, followed by lithium tert-butoxide (64.0 mg, $0.80 \mathrm{mmol}, 2$ equiv.). The vial was then sealed with a septum and brought outside the glovebox, where it was allowed to stir at room temperature for five hours. The reaction was then 
quenched with the addition of water $(3 \mathrm{~mL})$, and then to the reaction mixture was added ethyl acetate $(5 \mathrm{~mL})$. The layers were then separated, and the aqueous layer was then washed an additional two times with ethyl acetate $(2 \times 5 \mathrm{~mL})$. The organic layers were then combined, dried with sodium sulfate, filtered, and concentrated under reduced pressure. The crude reaction mixture was purified with the use of silica gel chromatography (5\% ethyl acetate in hexanes, stained in $\mathrm{KMnO}_{4}$ ) to afford a colorless oil that solidified to a white solid when placed in a freezer overnight (93.4 mg, 72\% yield). ${ }^{1} \mathrm{H}$ NMR $\left(500 \mathrm{MHz}, \mathrm{CDCl}_{3}\right) \delta 5.66(\mathrm{dd}, J=5.5,2.2 \mathrm{~Hz}, 1 \mathrm{H}), 5.59(\mathrm{dd}, J=$ $5.5,2.2 \mathrm{~Hz}, 1 \mathrm{H}), 4.60(\mathrm{dt}, J=6.0,2.2 \mathrm{~Hz}, 1 \mathrm{H}), 2.63(\mathrm{ddq}, J=17.0,6.8,2.2 \mathrm{~Hz}, 1 \mathrm{H}), 2.28(\mathrm{~d}, J=$ $17.0 \mathrm{~Hz}, 1 \mathrm{H}), 2.17(\mathrm{~s}, 1 \mathrm{H}), 1.22(\mathrm{~s}, 12 \mathrm{H}), 0.06(\mathrm{~s}, 6 \mathrm{H}) .{ }^{13} \mathrm{C} \mathrm{NMR}\left(126 \mathrm{MHz}, \mathrm{CDC}_{3}\right) \delta 129.3,126.6$, 83.4, 74.7, 43.6, 26.1, 24.9, 24.8, 18.4, -4.48, -4.54. (Due to the quadrupolar nature of boron, the carbon adjacent to boron was not detectable.) ${ }^{11} \mathrm{~B} \mathrm{NMR}\left(128 \mathrm{MHz}, \mathrm{CDCl}_{3}\right) \delta 33.60$. IR (neat) $v_{\max }$ 3055 (w), 2978 (s), 2956 (s), 2929 (s), 2895 (m), 2857 (s), 2368 (w), 2155 (w), 2144 (w), 2038 (w), 2019 (w), 1979 (m), 1968 (w), 1949 (w), 1472 (m), 1372 (s), 1345 (s), 1320 (s), 1256 (m), $1213(\mathrm{~m}), 1143(\mathrm{~s}), 1108(\mathrm{~m}), 1061(\mathrm{~s}), 1006(\mathrm{w}), 996(\mathrm{~m}), 909(\mathrm{~m}), 878(\mathrm{~m}), 851(\mathrm{~m}), 836(\mathrm{~s})$, $776(\mathrm{~s}), 739(\mathrm{w}), 668(\mathrm{~m}), 570(\mathrm{~m}) \mathrm{cm}^{-1}$. HRMS (DART+) m/z: $[\mathrm{M}+\mathrm{H}]^{+}$Calcd for $\mathrm{C}_{17} \mathrm{H}_{34} \mathrm{BO}_{3} \mathrm{Si}$ 325.2365; Found 325.2363.

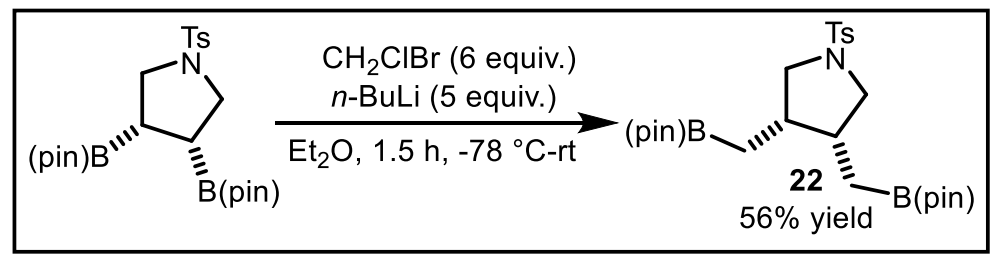

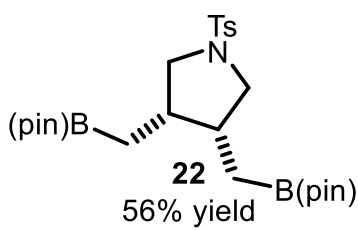
then flushed with nitrogen, and to it was added bromochloromethane ( $233 \mathrm{mg}, 1.8 \mathrm{mmol}, 6.0$ equiv.) and the vial was cooled to $-78{ }^{\circ} \mathrm{C}$. To the solution was then added $n$-butyllithium as a 2.5 M solution in hexanes $(96.1 \mathrm{mg}, 1.50 \mathrm{mmol}, 5.0$ equiv.) dropwise. The solution was then allowed to stir at this temperature for thirty minutes. The reaction was then allowed to warm to room temperature, and then stir for an additional hour. The reaction is then diluted with water $(5 \mathrm{~mL})$, and then to it is added additional diethyl ether $(5 \mathrm{~mL})$. The layers are then separated, and the aqueous layer is washed an additional two times with diethyl ether $(2 \times 10 \mathrm{~mL})$. The organic layers are then combined, dried with $\mathrm{MgSO}_{4}$, filtered, and concentrated under reduced pressure. The crude reaction mixture was purified with the use of silica gel chromatography (15-20\% ethyl acetate in hexanes, stained in CAM) to afford a colorless oil ( $85.0 \mathrm{mg}, 56 \%$ yield). ${ }^{1} \mathrm{H}$ NMR (500 $\left.\mathrm{MHz} \mathrm{CDCl}_{3}\right) \delta 7.71(\mathrm{t}, J=9.0 \mathrm{~Hz}, 2 \mathrm{H}), 7.28(\mathrm{~d}, J=8.0 \mathrm{~Hz}, 2 \mathrm{H}), 3.42(\mathrm{dd}, J=9.8,6.3 \mathrm{~Hz}, 2 \mathrm{H})$, $2.95(\mathrm{dd}, J=9.8,5.6 \mathrm{~Hz}, 2 \mathrm{H}), 2.42(\mathrm{~s}, 3 \mathrm{H}), 2.20(\mathrm{tt}, J=10.9,5.6 \mathrm{~Hz}, 2 \mathrm{H}), 1.21(\mathrm{~d}, J=4.1 \mathrm{~Hz}$, $12 \mathrm{H}), 0.66(\mathrm{dd}, J=15.8,4.5 \mathrm{~Hz}, 2 \mathrm{H}), 0.39(\mathrm{dd}, J=15.8,9.8 \mathrm{~Hz}, 2 \mathrm{H}) .{ }^{13} \mathrm{C} \mathrm{NMR}\left(151 \mathrm{MHz}, \mathrm{CDCl}_{3}\right)$ $\delta 143.1,134.4,129.6,127.6,83.3,53.7,38.2,24.91,24.86,21.6$. (Due to the quadrupolar nature of boron, the carbon adjacent to boron was not detectable.) ${ }^{11} \mathrm{~B} \mathrm{NMR}\left(160 \mathrm{MHz}, \mathrm{CDCl}_{3}\right) \delta 33.67$. IR (neat) $v_{\max } 2976(\mathrm{~m}), 2932(\mathrm{w}), 2886(\mathrm{w}), 1598(\mathrm{w}), 1371(\mathrm{~m}), 1343$ (s), 1271 (w), 1159 (s), 
1142 (s), 1107 (w), 1036 (w), $968(\mathrm{~m}), 847$ (m), 815 (w), $755(\mathrm{w}), 664(\mathrm{~m}), 590(\mathrm{~m}), 548(\mathrm{~m}) \mathrm{cm}^{-}$

${ }^{1}$. HRMS (DART+) m/z: [M+H] ${ }^{+}$Calcd for $\mathrm{C}_{25} \mathrm{H}_{42} \mathrm{~B}_{2} \mathrm{NO}_{6} \mathrm{~S}$ 506.2914; Found 506.2934.

\section{Procedures and Characterization of Compounds for the synthesis of aristeromycin}
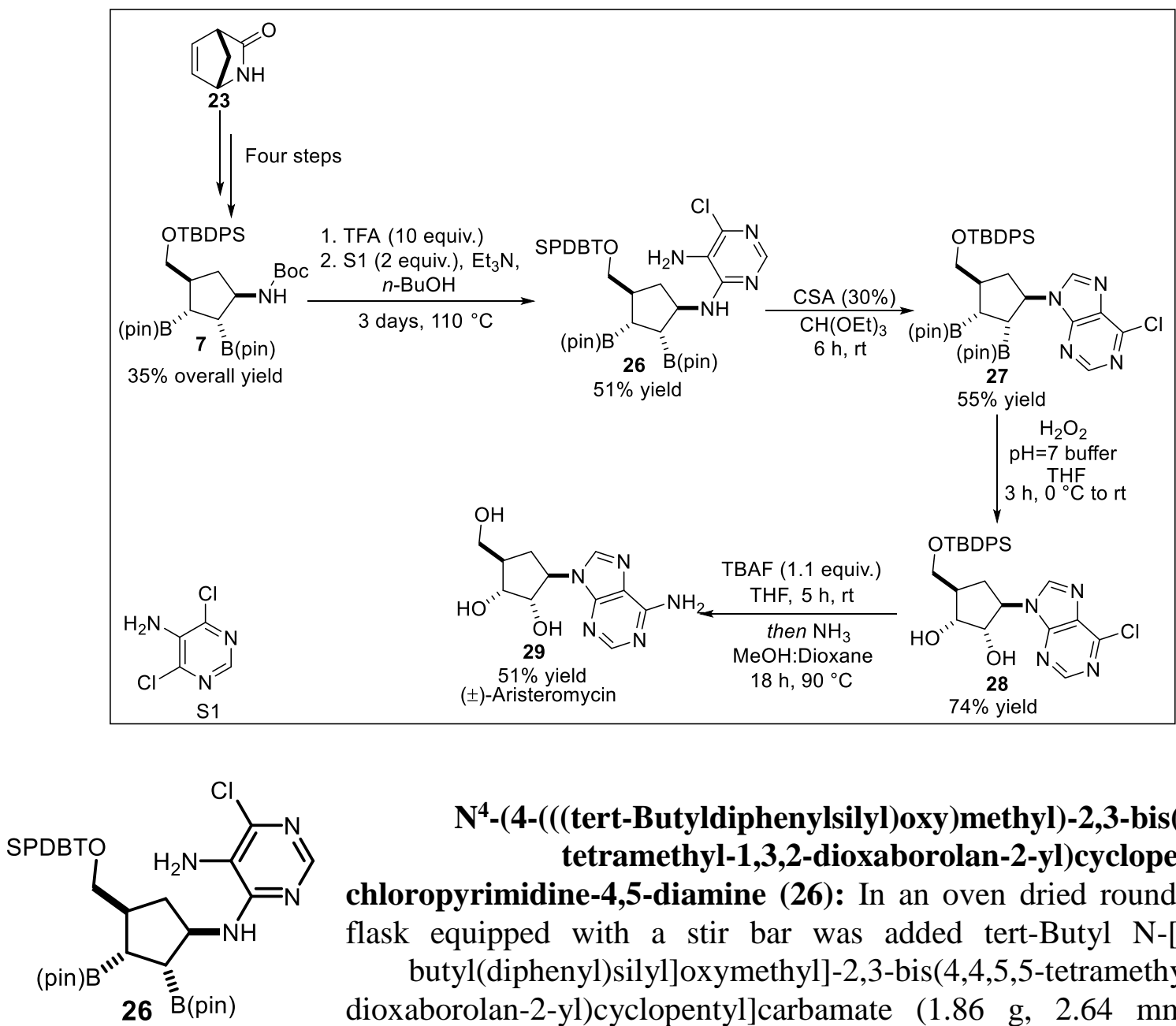

$\mathrm{N}^{4}$-(4-(((tert-Butyldiphenylsilyl)oxy)methyl)-2,3-bis(4,4,5,5tetramethyl-1,3,2-dioxaborolan-2-yl)cyclopentyl)-6chloropyrimidine-4,5-diamine (26): In an oven dried round bottom flask equipped with a stir bar was added tert-Butyl N-[4-[[tertbutyl(diphenyl)silyl]oxymethyl]-2,3-bis(4,4,5,5-tetramethyl-1,3,2dioxaborolan-2-yl)cyclopentyl]carbamate (1.86 g, $2.64 \mathrm{mmol})(7$, synthesized in four steps, see synthesis of compounds $\mathbf{2 4}, \mathbf{2 5}, \mathbf{1 7}$, and $\mathbf{7}$ located in the supplementary information), and dichloromethane $(8.62 \mathrm{~mL})$, and then cooled to $0{ }^{\circ} \mathrm{C}$. To the solution was then added 2,2,2-trifluoroacetic acid (3.01 g, $26.4 \mathrm{mmol}, 10.0$ equiv.) dropwise and allowed to stir at this temperature for 15 minutes. The reaction was then allowed to warm to room temperature and the reaction was monitored by TLC until completion (approximately 30 minutes). To the reaction was then added toluene $(4.00 \mathrm{~mL})$, and the reaction was concentrated under reduced pressure. To the reaction was added another aliquot of toluene $(4.00 \mathrm{~mL})$, and the reaction mixture was concentrated again under reduced pressure. The reaction was allowed to remain under reduced pressure for another thirty minutes. The residue was then dissolved in anhydrous n-butanol $(2.15 \mathrm{~mL})$, and to it was added 4,6-dichloropyrimidin-5-amine (897 mg, $5.47 \mathrm{mmol}, 2.07$ equiv.) followed by N,N-diethylethanamine $(2.67 \mathrm{~g}, 26.4 \mathrm{mmol}, 10.0$ equiv.). The reaction was then sealed with a septum under air, and allowed to stir at $110{ }^{\circ} \mathrm{C}$ for three days. The reaction was then concentrated under reduced pressure. The crude mixture was then purified with the use of silica gel chromatography (20-50\% ethyl acetate in hexanes) to afford 
an orange/brown solid (976 mg, 51\% yield). ${ }^{1} \mathrm{H}$ NMR (600 MHz, $\left.\mathrm{CDCl}_{3}\right) \delta 8.05(\mathrm{~s}, 1 \mathrm{H}), 7.68-7.59$ $(\mathrm{m}, 4 \mathrm{H}), 7.42-7.31(\mathrm{~m}, 6 \mathrm{H}), 4.48(\mathrm{~s}, 1 \mathrm{H}), 3.80(\mathrm{dd}, J=9.3,2.8 \mathrm{~Hz}, 1 \mathrm{H}), 3.71(\mathrm{dd}, J=9.3,2.8 \mathrm{~Hz}$, 1H), 2.40-2.36 (m, 2H), 1.67-1.50 (m, 3H), 1.29-1.17 (m, 24H), $1.06(\mathrm{~s}, 9 \mathrm{H}) .{ }^{13} \mathrm{C} \mathrm{NMR}(126 \mathrm{MHz}$, $\left.\mathrm{CDCl}_{3}\right) \delta 154.7,149.7,142.3,135.7,134.2,129.7,127.7,121.8,83.6,83.2,66.7,55.8,42.5,36.8$, $27.2,25.1,24.9,24.8,24.7,19.6$. (Due to the quadrupolar nature of boron, the carbon adjacent to boron was not detectable.) ${ }^{11} \mathrm{~B}$ NMR $\left(160 \mathrm{MHz}, \mathrm{CDCl}_{3}\right) \delta 34.55$. IR (neat) $v_{\max } 3358$ (br), 2977 (w), $2931(\mathrm{w}), 2857(\mathrm{w}), 1576(\mathrm{~s}), 1470(\mathrm{~m}), 1427(\mathrm{~m}), 1370(\mathrm{~s}), 1318(\mathrm{~m}), 1215(\mathrm{~m}), 1140(\mathrm{~s})$, 1107 (s), 1008 (w), $969(\mathrm{w}), 851(\mathrm{~m}), 824(\mathrm{~m}), 753(\mathrm{~s}), 701(\mathrm{~s}), 667(\mathrm{~m}), 612(\mathrm{~m}), 579(\mathrm{w}), 553$ (w) $\mathrm{cm}^{-1}$. HRMS (DART+) m/z: [M+H] ${ }^{+}$Calcd for $\mathrm{C}_{38} \mathrm{H}_{56} \mathrm{~B}_{2} \mathrm{~N}_{4} \mathrm{O}_{5} \mathrm{SiCl} 733.3889$; Found 733.3906.

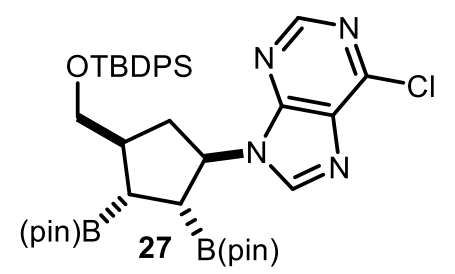

\section{9-(-4-(((tert-Butyldiphenylsilyl)oxy)methyl)-2,3-bis(4,4,5,5- tetramethyl-1,3,2-dioxaborolan-2-yl)cyclopentyl)-9H-purin-6-} amine (27): In an oven dried two dram vial equipped with a stirbar was added $\quad \mathrm{N}^{4}-(4-(($ tert-Butyldiphenylsilyl)oxy)methyl)-2,3bis(4,4,5,5-tetramethyl-1,3,2-dioxaborolan-2-yl)cyclopentyl)-6chloropyrimidine-4,5-diamine (26) $(150 \mathrm{mg}, 0.205 \mathrm{mmol})$, followed by diethoxymethoxyethane (912 mg, $6.16 \mathrm{mmol}, 30.0$ equiv.), and [(1S,4R)-7,7-dimethyl-2-oxonorbornan-1-yl]methanesulfonic acid (14.3 mg, $61.4 \mu \mathrm{mol}, 0.30$ equiv.) and the reaction vial was sealed with a septum under air and allowed to stir for six hours at room temperature. The reaction was then quenched with saturated sodium bicarbonate $(2 \mathrm{~mL})$, and then extracted three times with ethyl acetate $(3 \times 5 \mathrm{~mL})$. The organic layers were then collected and washed with water $(15 \mathrm{~mL})$, followed by brine $(15 \mathrm{~mL})$. The organic layer was then dried with $\mathrm{Na}_{2} \mathrm{SO}_{4}$, filtered, and concentrated under reduced pressure. The crude mixture was then purified with the use of silica gel chromatography (15-20\% ethyl acetate in hexanes), to afford a light yellow solid (83.9 mg, $55 \%$ yield). ${ }^{1} \mathrm{H}$ NMR $\left(600 \mathrm{MHz}, \mathrm{CDCl}_{3}\right) \delta 8.66(\mathrm{~s}, 1 \mathrm{H}), 8.16(\mathrm{~s}, 1 \mathrm{H}), 7.65(\mathrm{t}, J=7.8 \mathrm{~Hz}, 4 \mathrm{H}), 7.41$ $(\mathrm{t}, J=7.8 \mathrm{~Hz}, 2 \mathrm{H}), 7.35(\mathrm{td}, J=7.4,1.0 \mathrm{~Hz}, 4 \mathrm{H}) 5.01(\mathrm{q}, J=8.4 \mathrm{~Hz}, 1 \mathrm{H}), 3.82(\mathrm{dd}, J=9.9,5.3$ $\mathrm{Hz}, 1 \mathrm{H}), 3.70(\mathrm{dd}, J=9.9,5.3 \mathrm{~Hz}, 1 \mathrm{H}), 2.47(\mathrm{dt}, J=12.8,7.8 \mathrm{~Hz}, 1 \mathrm{H}), 2.41(\mathrm{dq}, J=12.8,6.0 \mathrm{~Hz}$, $1 \mathrm{H}), 2.19(\mathrm{t}, J=9.3 \mathrm{~Hz}, 1 \mathrm{H}), 2.12(\mathrm{dt}, J=12.8,7.8 \mathrm{~Hz}, 1 \mathrm{H}), 1.78(\mathrm{dd}, J=9.3,6.0 \mathrm{~Hz}, 1 \mathrm{H}) 1.24$ $(\mathrm{d}, J=10.4 \mathrm{~Hz}, 12 \mathrm{H}), 1.11(\mathrm{~d}, J=25.9 \mathrm{~Hz}, 12 \mathrm{H}), 1.04(\mathrm{~s}, 9 \mathrm{H}) \cdot{ }^{13} \mathrm{C} \mathrm{NMR}\left(151 \mathrm{MHz}, \mathrm{CDCl}_{3}\right) \delta$ 152.0, 151.3, 150.6, 145.1, 135.8, 133.9, 132.2, 129.7, 127.7, 83.7, 83.5, 67.0, 59.6, 42.7, 36.0, $27.0,25.1,24.8,24.7,19.4,8.7$. (Due to the quadrupolar nature of boron, the carbon adjacent to boron was not detectable.) ${ }^{11} \mathrm{~B}$ NMR $\left(160 \mathrm{MHz}, \mathrm{CDCl}_{3}\right) \delta 35.25$. IR (neat) $v_{\max } 2977(\mathrm{w}), 2931$ (w), $2857(\mathrm{w}), 1641(\mathrm{w}), 1590(\mathrm{~m}), 1557(\mathrm{~m}), 1471(\mathrm{w}), 1427(\mathrm{w}), 1371$ (s), 1321 (s), $1214(\mathrm{~m})$, 1195 (m), 1140 (s), 1110 (s), 1008 (w), 969 (w), 935 (w), 910 (w), 851 (m), 823 (m), 793 (w), 732 (s), $701(\mathrm{~s}), 647(\mathrm{w}), 637(\mathrm{w}), 613(\mathrm{w}), 578(\mathrm{w}) \mathrm{cm}^{-1}$. HRMS (DART+) m/z: [M+H] $]^{+}$Calcd for $\mathrm{C}_{39} \mathrm{H}_{54} \mathrm{~B}_{2} \mathrm{~N}_{4} \mathrm{O}_{5} \mathrm{SiCl}$ 743.3733; Found 743.3747.

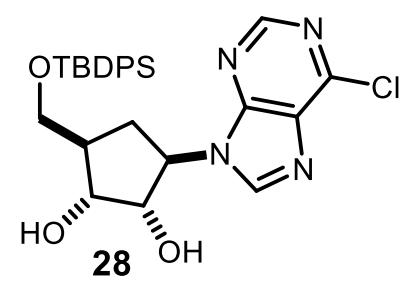

3-(((tert-Butyldiphenylsilyl)oxy)methyl)-5-(6-chloro-9H-purin-9yl)cyclopentane-1,2-diol (28): In a 2 dram vial equipped with a stirbar was added 9-(-4-(((tert-Butyldiphenylsilyl)oxy)methyl)-2,3-bis(4,4,5,5-

tetramethyl-1,3,2-dioxaborolan-2-yl)cyclopentyl)-9H-purin-6-amine (27) $(76.4 \mathrm{mg}, 0.103 \mathrm{mmol})$, followed by tetrahydrofuran $(2.00 \mathrm{~mL})$, and $\mathrm{pH}=7$ buffer $(2.00 \mathrm{~mL})$. The reaction mixture was then cooled to $0{ }^{\circ} \mathrm{C}$ and to it was added hydrogen peroxide (35\% aqueous solution, $0.500 \mathrm{~mL}$ ) dropwise. The reaction 
was then warmed to room temperature and allowed to stir for three hours. The reaction was then cooled to $0{ }^{\circ} \mathrm{C}$ and to it was added saturated sodium thiosulfate $(1 \mathrm{~mL})$ dropwise. To the reaction was then added ethyl acetate $(5 \mathrm{~mL})$ and the layers were separated. The aqueous layer was then washed an additional two times with ethyl acetate $(2 \times 5 \mathrm{~mL})$, and the organic layers were then combined, dried with $\mathrm{Na}_{2} \mathrm{SO}_{4}$, filtered, and concentrated under reduced pressure. The crude mixture was then purified with the use of silica gel chromatography (30-80\% ethyl acetate in hexanes) to afford a white solid (40.6 mg, 74\% yield). ${ }^{1} \mathrm{H} \mathrm{NMR}\left(500 \mathrm{MHz}, \mathrm{CDCl}_{3}\right) \delta 8.64(\mathrm{~s}, 1 \mathrm{H})$, $8.08(\mathrm{~s}, 1 \mathrm{H}), 7.66-7.63(\mathrm{~m}, 4 \mathrm{H}), 7.46-7.35(\mathrm{~m}, 6 \mathrm{H}), 4.81(\mathrm{dt}, J=11.1,7.8 \mathrm{~Hz}, 1 \mathrm{H}), 4.54(\mathrm{dd}, J$ $=7.8,5.7 \mathrm{~Hz}, 1 \mathrm{H}), 4.31(\mathrm{dd}, J=5.7,3.2 \mathrm{~Hz}, 1 \mathrm{H}), 3.88(\mathrm{dd}, J=10.3,4.8 \mathrm{~Hz}, 1 \mathrm{H}), 3.76(\mathrm{dd}, J=$ $10.3,4.8 \mathrm{~Hz}, 1 \mathrm{H}), 2.41$ (tdd, $J=13.1,10.3,6.5 \mathrm{~Hz}, 2 \mathrm{H}), 2.18(\mathrm{td}, J=11.1,10.3,7.9 \mathrm{~Hz}, 1 \mathrm{H}), 1.06$ (s, 9H). ${ }^{13} \mathrm{C}$ NMR $(126 \mathrm{MHz}, \mathrm{CDCl} 3) \delta 151.9,151.5,144.9,135.7,135.7,133.2,132.2,130.1$, 128.0, 76.0, 73.3, 64.8, 62.4, 45.5, 28.6, 27.0, 19.4. IR (neat) $v_{\max } 3322$ (br), $3071(\mathrm{w}), 2930(\mathrm{w})$, 2867 (w), 1591 (m), 1560 (m), 1492 (w), 1471 (w), 1427 (m), 1394 (w), 1337 (m), 1257 (w), 1200 (m), 1149 (w), 1110 (s), $997(\mathrm{~m}), 942$ (m), 907 (m), 870 (w), $842(\mathrm{w}), 823(\mathrm{~m}), 792(\mathrm{w}), 732(\mathrm{~s})$, $701(\mathrm{~s}), 649(\mathrm{~m}), 635$ 9m), $605(\mathrm{w}), 569(\mathrm{w}) \mathrm{cm}^{-1}$. HRMS (DART+) m/z: [M+H] ${ }^{+}$Calcd for $\mathrm{C}_{27} \mathrm{H}_{32} \mathrm{~N}_{4} \mathrm{O}_{3} \mathrm{SiCl}$ 523.1927; Found 523.1924.

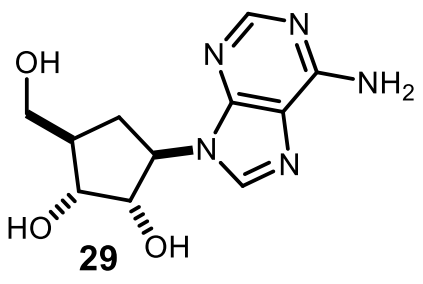

3-(6-Amino-9H-purin-9-yl)-5-(hydroxymethyl)cyclopentane-1,2-
diol (( $( \pm)$-aristeromycin) (29): To an oven dried two dram vial
equipped with a stirbar was added 3-(((tert-
Butyldiphenylsilyl)oxy)methyl)-5-(6-chloro-9H-purin-9-
yl)cyclopentane-1,2-diol (28) $(37.3 \mathrm{mg}, 71.3 \mu \mathrm{mol})$, followed by
tetrahydrofuran $(0.745 \mathrm{~mL})$. To the mixture was then added a $1.0 \mathrm{M}$ solution of tetrabutylammonium fluoride in tetrahydrofuran $(20.4 \mathrm{mg}, 78.2 \mu \mathrm{mol}, 1.1$ equiv., 78.2 $\mu \mathrm{L})$ dropwise. The reaction vial was then sealed with a septum and allowed to stir until completion as indicated by TLC (five hours). After completion, the reaction was concentrated under reduced pressure. To the crude mixture was then added dioxane $(0.37 \mathrm{~mL})$ followed by a $7 \mathrm{M}$ ammonia solution in methanol $(0.745 \mathrm{~mL})$. The reaction was then sealed with a screw cap and tape under air and allowed to stir at $90{ }^{\circ} \mathrm{C}$ for twelve hours. To the reaction was then added silica, and the reaction mixture was concentrated under reduced pressure. The adsorbed product was then purified with the use of silica gel chromatography (10-20\% methanol in dichloromethane), to afford a white powder $(9.67 \mathrm{mg}, 51 \%$ yield $)$. The spectral data was in accordance with the literature. ${ }^{14}$

\section{VIII: Gram-scale reaction}

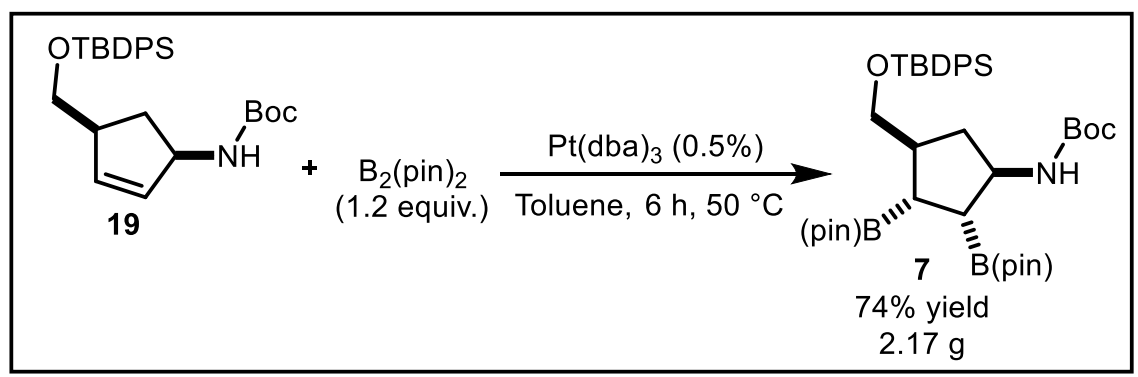




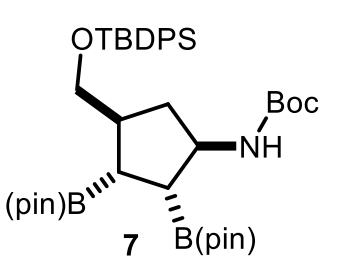

tert-Butyl-N-[4-[[tert-butyl(diphenyl)silyl]oxymethyl]-2,3-bis(4,4,5,5tetramethyl-1,3,2-dioxaborolan-2-yl)cyclopentyl]carbamate (7): To a flame dried $25 \mathrm{~mL}$ round bottom flask equipped with a stirbar was added tert-Butyl-((cis)-4-(((tert-butyldiphenylsilyl)oxy)methyl)cyclopent-2-en-1yl)carbamate (19) (1.86 g, $4.12 \mathrm{mmol})$, bis(pinacolato)diboron (1.25 g, 4.94 mmol, 1.2 equiv.), tris(dibenzylideneacetone)platinum(0) (18.5 mg, 20.6 $\mu \mathrm{mol}, 0.5 \%)$, and toluene $(12.1 \mathrm{~mL})$. The reaction was then sealed under air with a septum and was allowed to stir for six hours at $50{ }^{\circ} \mathrm{C}$, and then concentrated under reduced pressure. The crude reaction mixture was purified with the use of silica gel chromatography (5-20\% ethyl acetate in hexanes, stained in $\left.\mathrm{KMnO}_{4}\right)$ to afford a white solid $(2.17 \mathrm{~g}, 74 \%$ yield). The spectral data and reaction diastereoselectivity was in accordance with data presented previously in the supporting information for compound 7.

\section{IX: References:}

1. Szymaniak, A.A.; Zhang, C.; Coombs, J.R.; Morken, J.P. Enantioselective Synthesis of Nonracemic Geminal Silylboronates by Pt-Catalyzed Hydrosilylation. ACS Catal. 2018, 8, 2897.

2. Frohner, W.; Monse, B.; Braxmeier, T.M.; Casiraghi, L.; Sahagun, H.; Seneci, P. Regiospecific Synthesis of Mono-N-substituted Indolopyrrolocarbazoles. Org. Lett. 2005, 7, 4573.

3. Chen, C.L.; Chiu, T.W.; Chen, Y.W.; Fang, J.M. Substituent and solvent effects in the 1,3dipolar cycloadditions for synthesis of anti-influenza agent peramivir and its analog. Tetrahedron 2019, 75, 4458.

4. Westwood, N.B.; Waler, R.T. Synthesis and biological properties of a new series of 5substituted-pyrimidine-L-nucleoside analogues. Tetrahedron 1998, 54, 13391.

5. Chen, Z.; Liang, J.; Yin, J.; Yu, G-A.; Liu, S.H. Alder-ene reaction of aryne with olefins. Tet. Lett. 2013, 54, 5785.

6. Zhu, Y.; Colomer, I.; Thompson, A.L.; Donohoe, T.J. HFIP Solvent Enables Alcohols To Act as Alkylating Agents in Stereoselective Heterocyclization. J. Am. Chem. Soc. 2019, $141,6489$.

7. Bunnelle, W.H.; Isbell, T.A. The influence of remote heteroatom substituents on the stereoselectivity of cyclopentene ozonolysis. J. Org. Chem. 1992, 57, 729.

8. Kelleghan, A.V.; Busacca, C.A.; Sarvestani, M.; Volchkov, I.; Medina, J.M.; Garg, N.K. Safety Assessment of Benzyne Generation from a Silyl Triflate Precursor. Org. Lett. 2020, 22, 1665.

9. Qiu, X-L.; Qing, F-L. Synthesis of 3'-Deoxy-3'-difluoromethyl Azanucleosides from trans-4-Hydroxy-1-proline. J. Org. Chem. 2005, 70, 3826.

10. Krogsgaard, N.; Storgaard, M.; Moller, C.; Demmer, C.S.; Hansen, J.; Han, L.; Monrad, R.N.; Nielsen, B.; Tapken, D.; Pickering, D.S.; Kastrup, J.S.; Frydenvang, K.; Bunch, L. Structure-Activity Relationship Study of Ionotropic Glutamate Receptor Antagonist 
(2S,3R)-3-(3-Carboxyphenyl)pyrrolidine-2-carboxylic Acid. J. Med. Chem. 2015, 58, 6131.

11. Mal, D.; Jana, A.; Ray, S.; Bhattacharya, S.; Patra, A.; De, S.R. DBU-CH $\mathrm{CH}_{3}$, a Potential Substitute for $\mathrm{CH}_{2} \mathrm{~N}_{2}$ in the Preparation of Methyl Esters and Methyl Aryl Ethers: Studies with Assorted Acids. Synthetic Communications 2008, 38, 3937.

12. Coggiola, I.M. 2,5-Dihydro-2-Furoic Acid: A Product of the Anaerobic Decomposition of Ascorbic Acid. Nature 1963, 200, 954.

13. You, C.; Studer, A. Synthesis of 1,3-Bis-(boryl)alkanes through Boronic Ester Induced Consecutive Double 1,2-Migration. Angew. Chem., Int. Ed. 2020, 59, 17245.

14. Rajappan, V.P.; Yin, X.; Schneller, S.W. A flexible synthesis of carbanucleosides and 5'nor-1'-homo carbanucleosides from a common precursor. Tetrahedron 2002, 58, 9889. 
Vendola, Allais, Dechert Schmitt, Lee, Singer, and Morken Supplementary Information

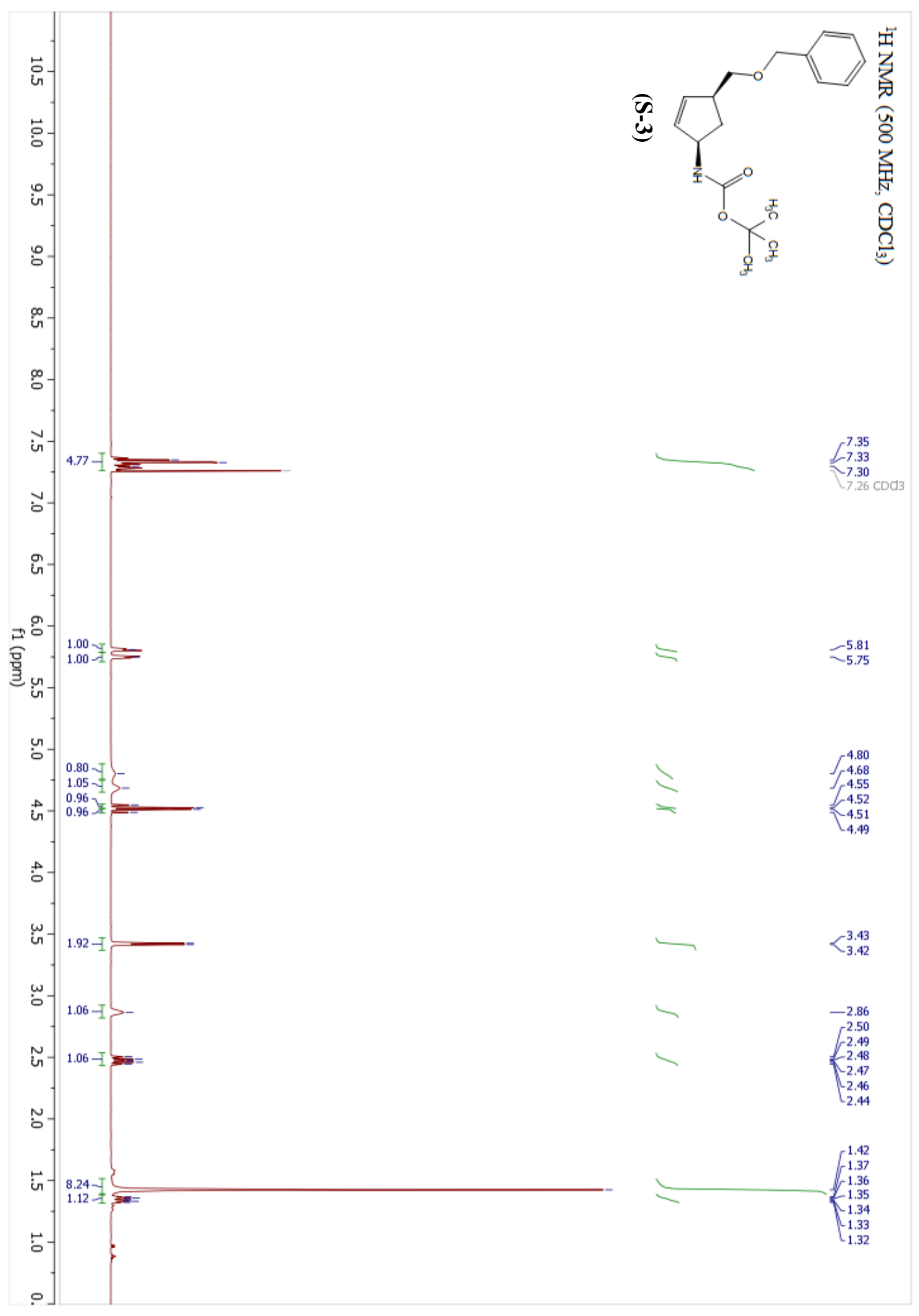


Vendola, Allais, Dechert Schmitt, Lee, Singer, and Morken Supplementary Information

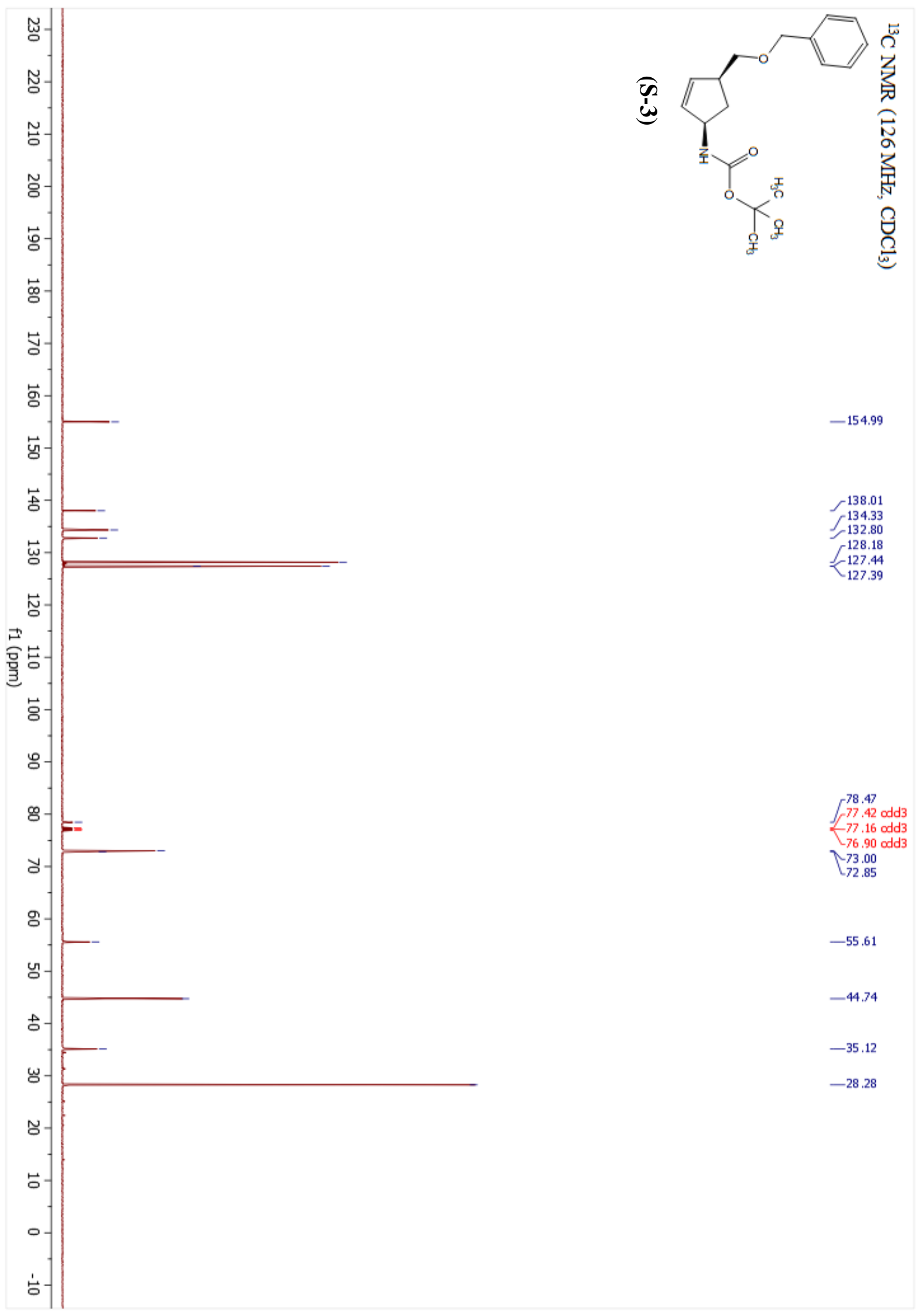


Vendola, Allais, Dechert Schmitt, Lee, Singer, and Morken Supplementary Information

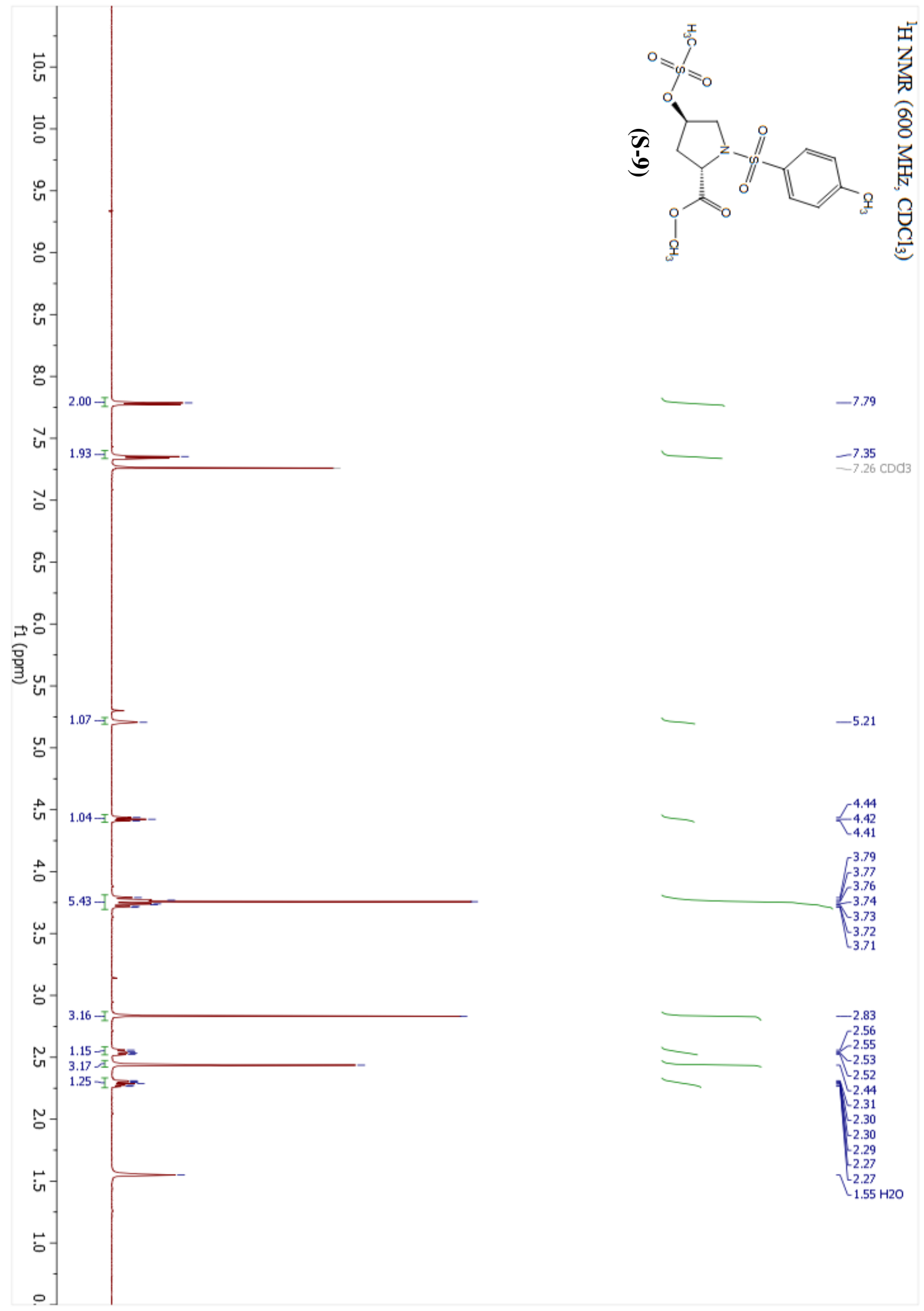


Vendola, Allais, Dechert Schmitt, Lee, Singer, and Morken Supplementary Information

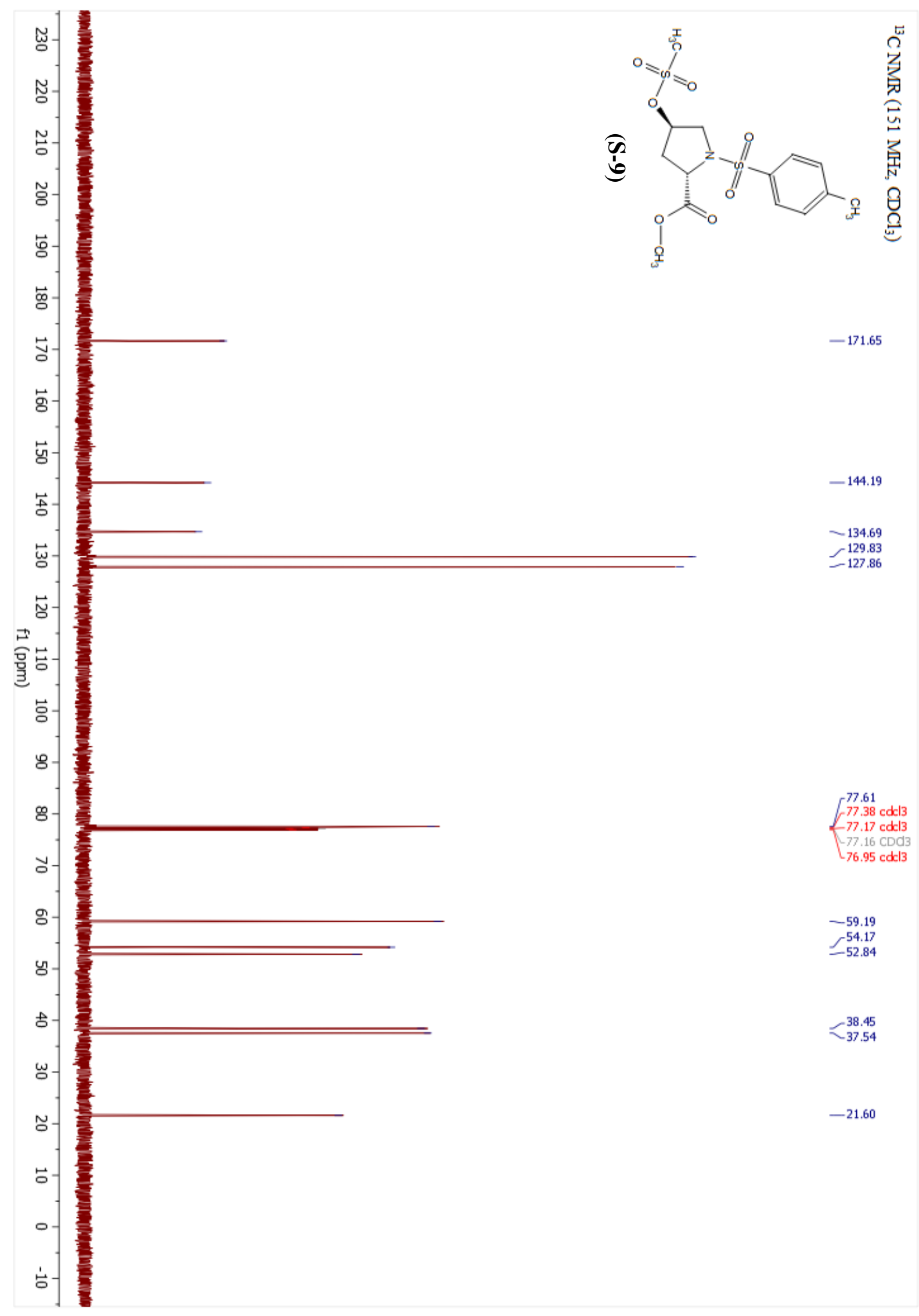


Vendola, Allais, Dechert Schmitt, Lee, Singer, and Morken Supplementary Information

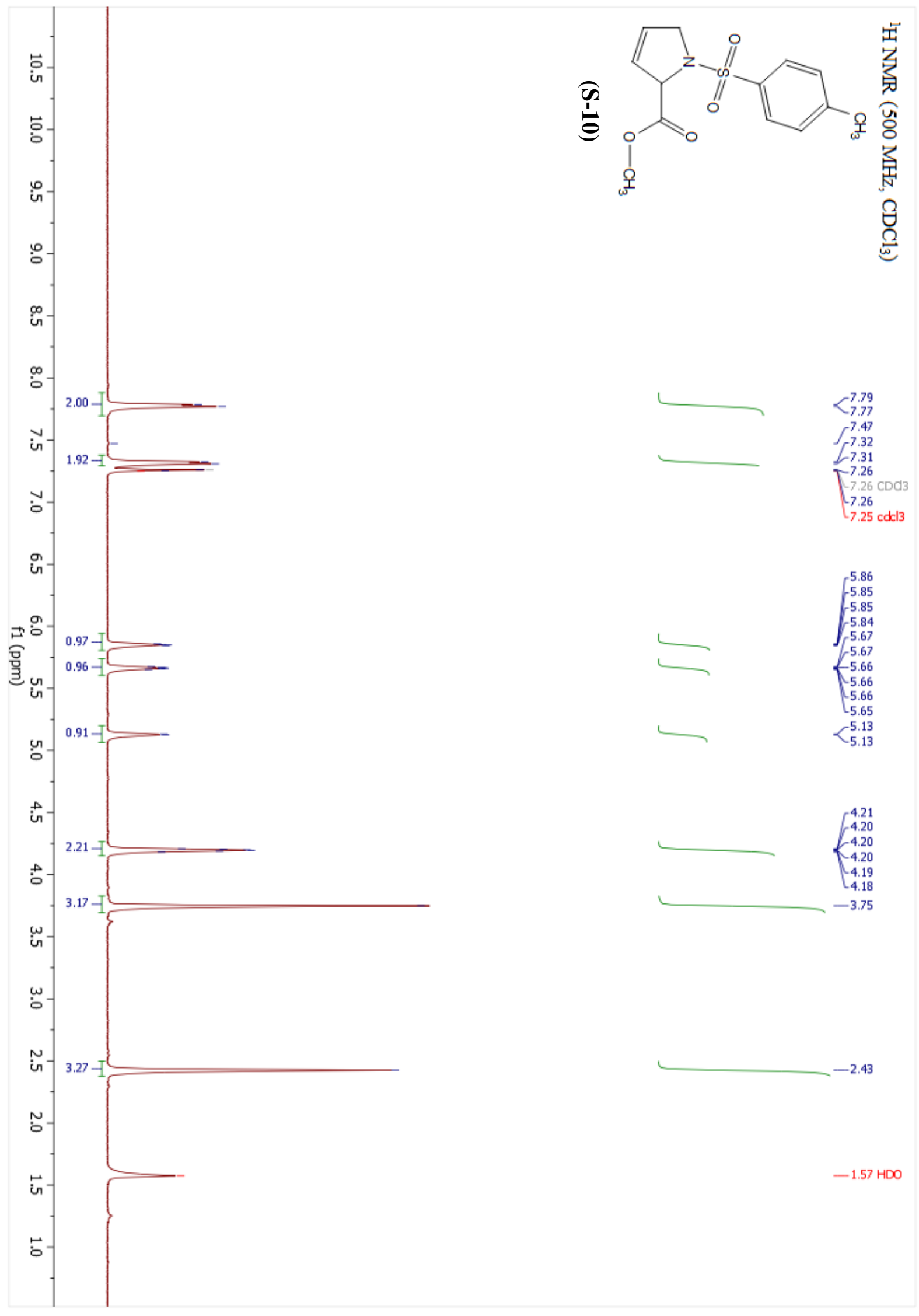


Vendola, Allais, Dechert Schmitt, Lee, Singer, and Morken Supplementary Information

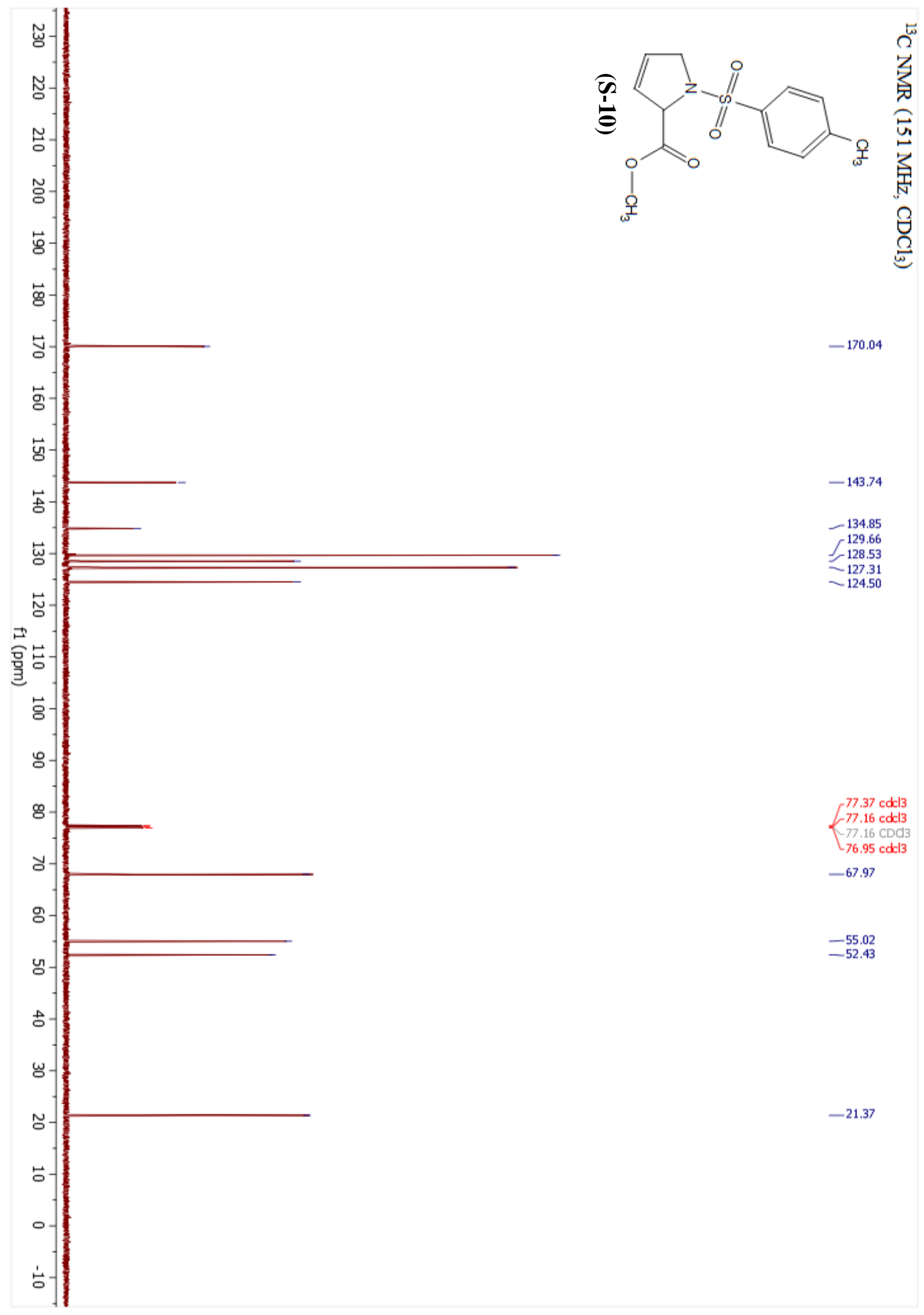


Vendola, Allais, Dechert Schmitt, Lee, Singer, and Morken Supplementary Information

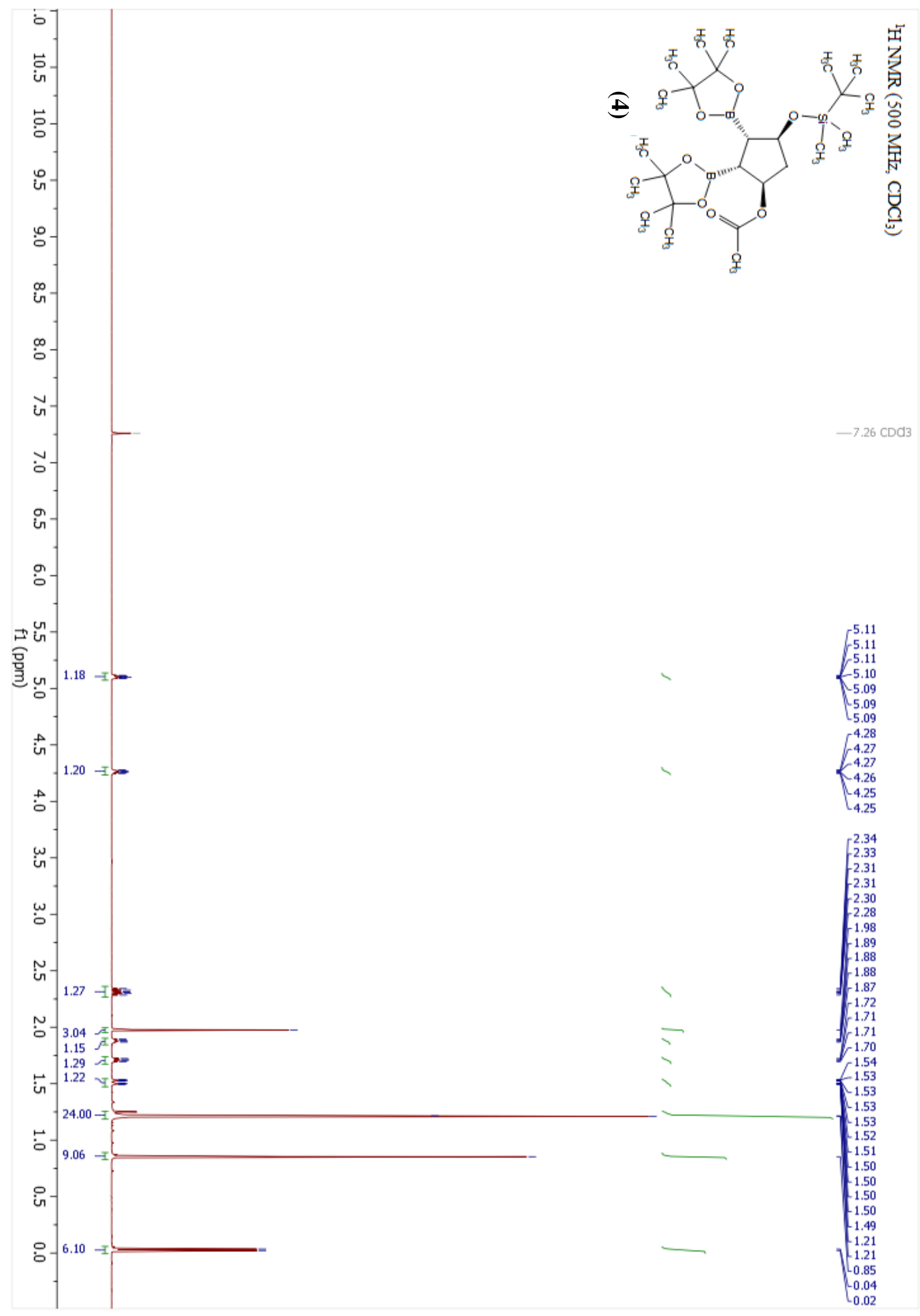


Vendola, Allais, Dechert Schmitt, Lee, Singer, and Morken Supplementary Information

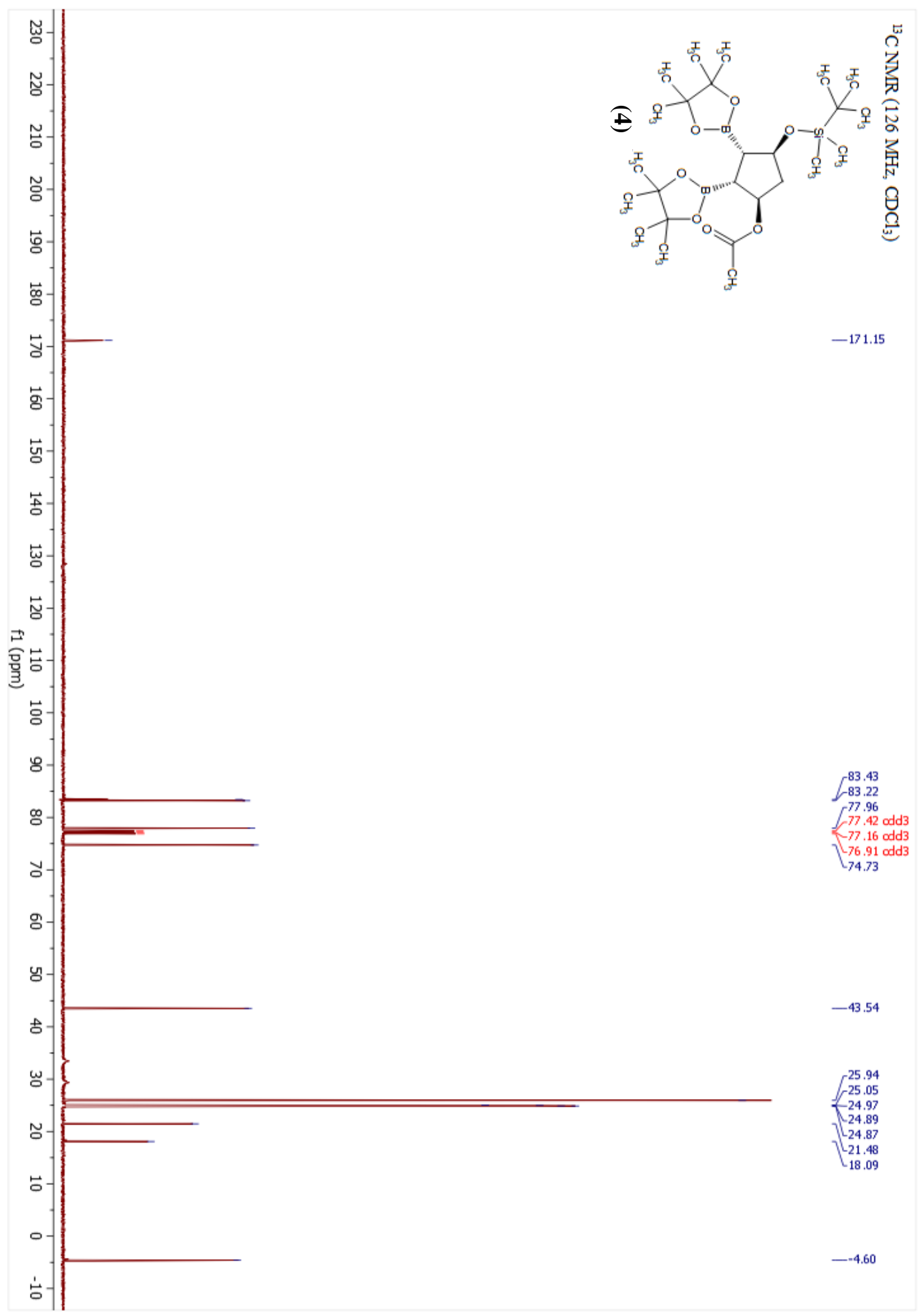


Vendola, Allais, Dechert Schmitt, Lee, Singer, and Morken Supplementary Information

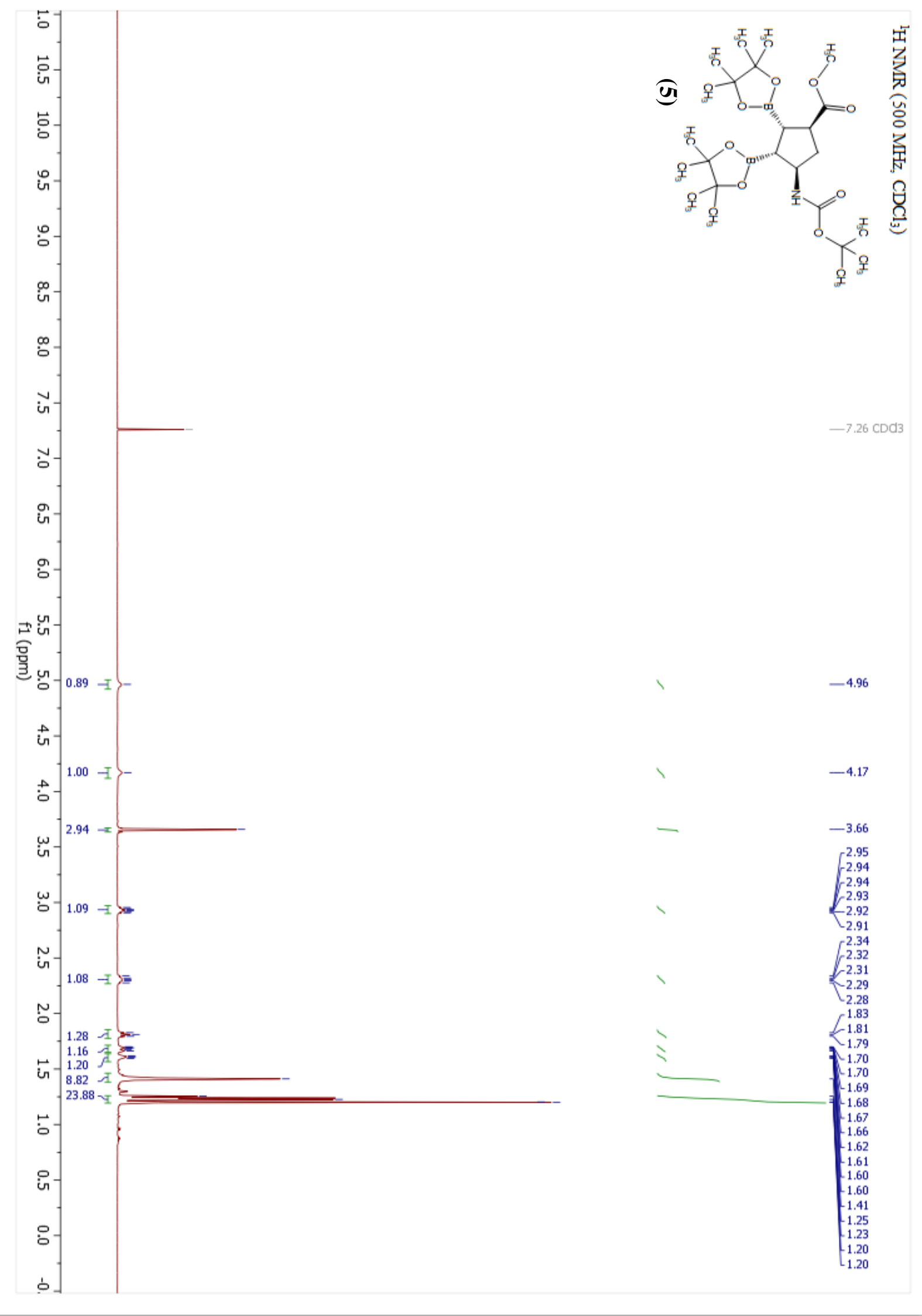


Vendola, Allais, Dechert Schmitt, Lee, Singer, and Morken Supplementary Information

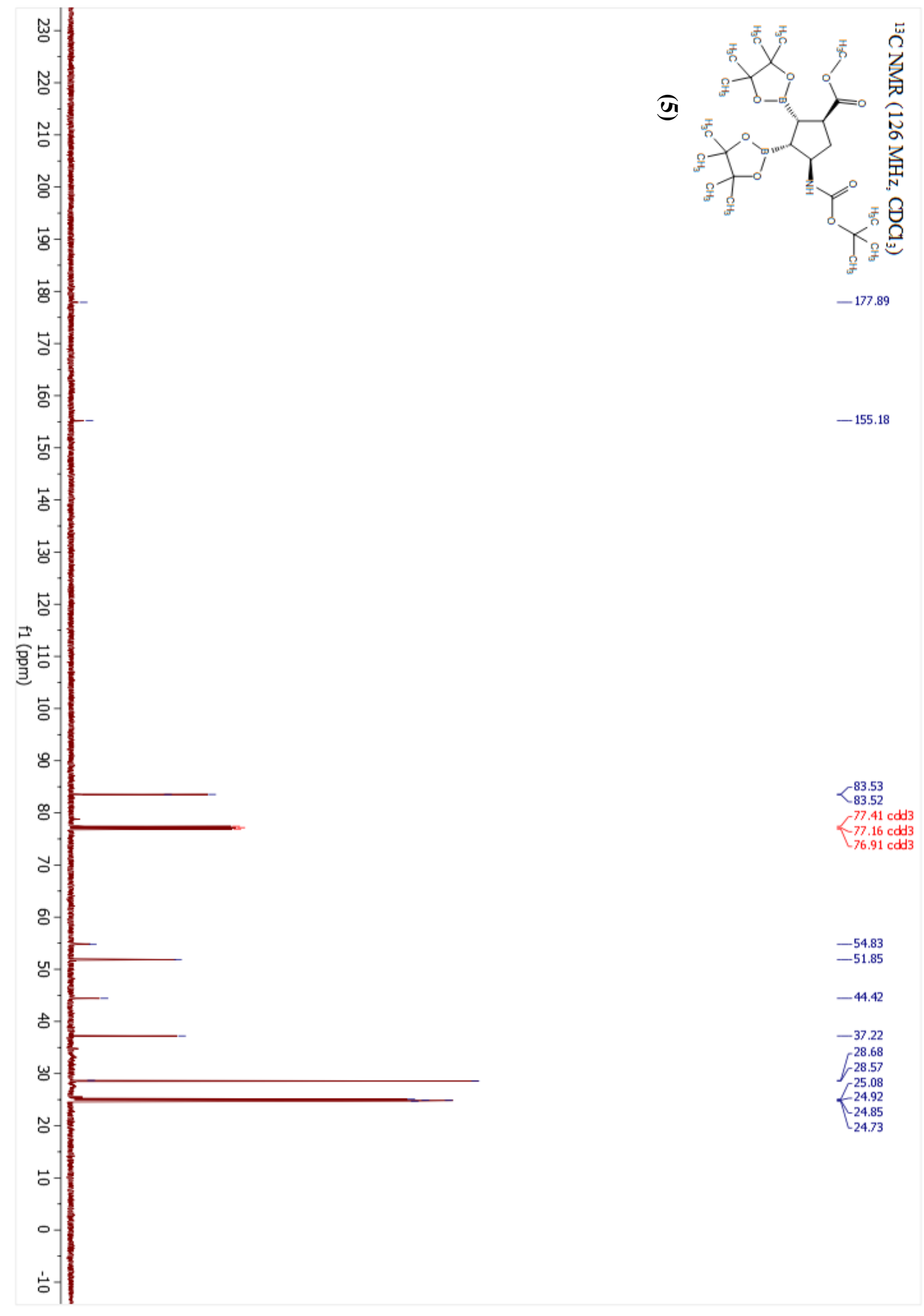


Vendola, Allais, Dechert Schmitt, Lee, Singer, and Morken Supplementary Information

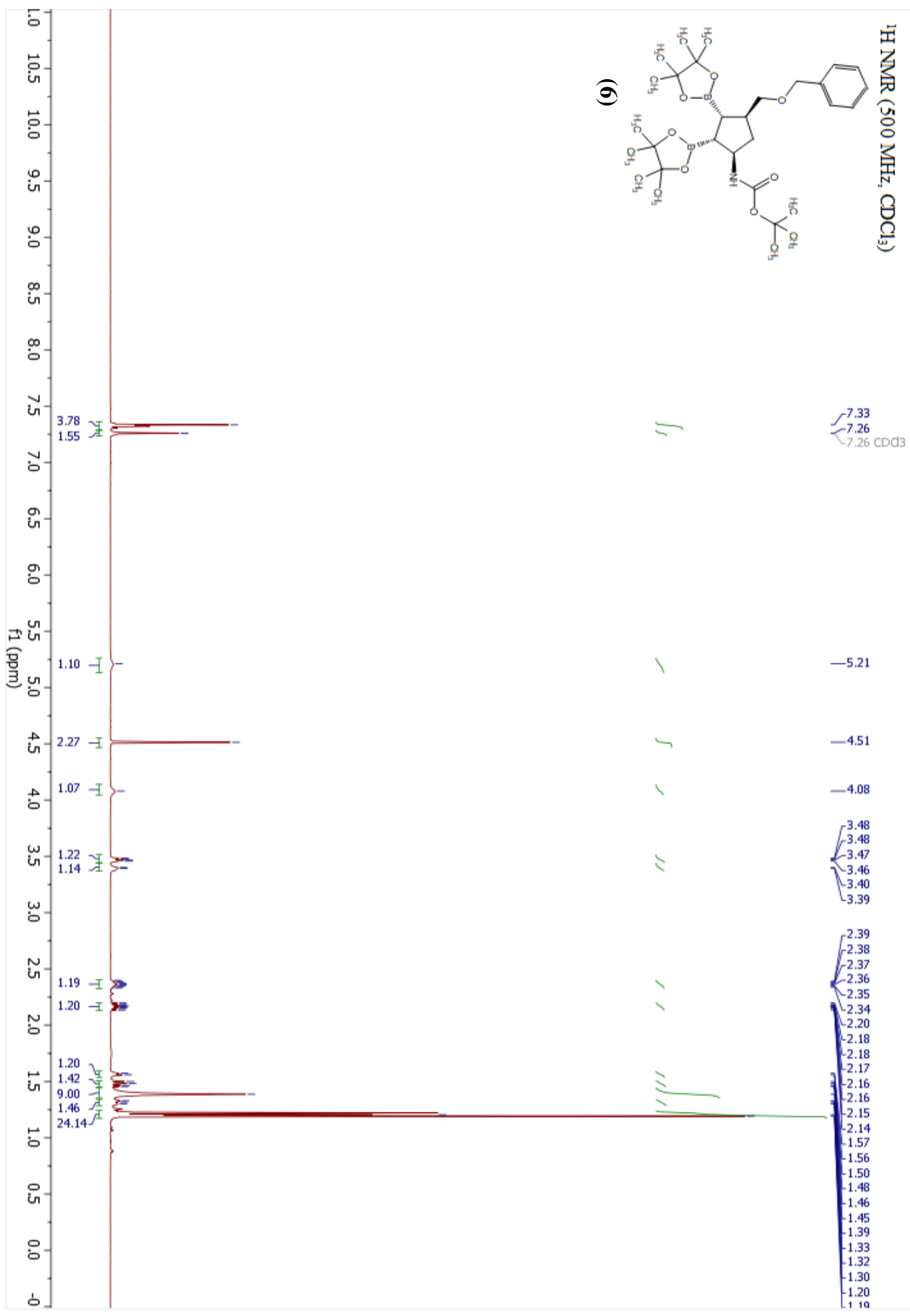


Vendola, Allais, Dechert Schmitt, Lee, Singer, and Morken Supplementary Information

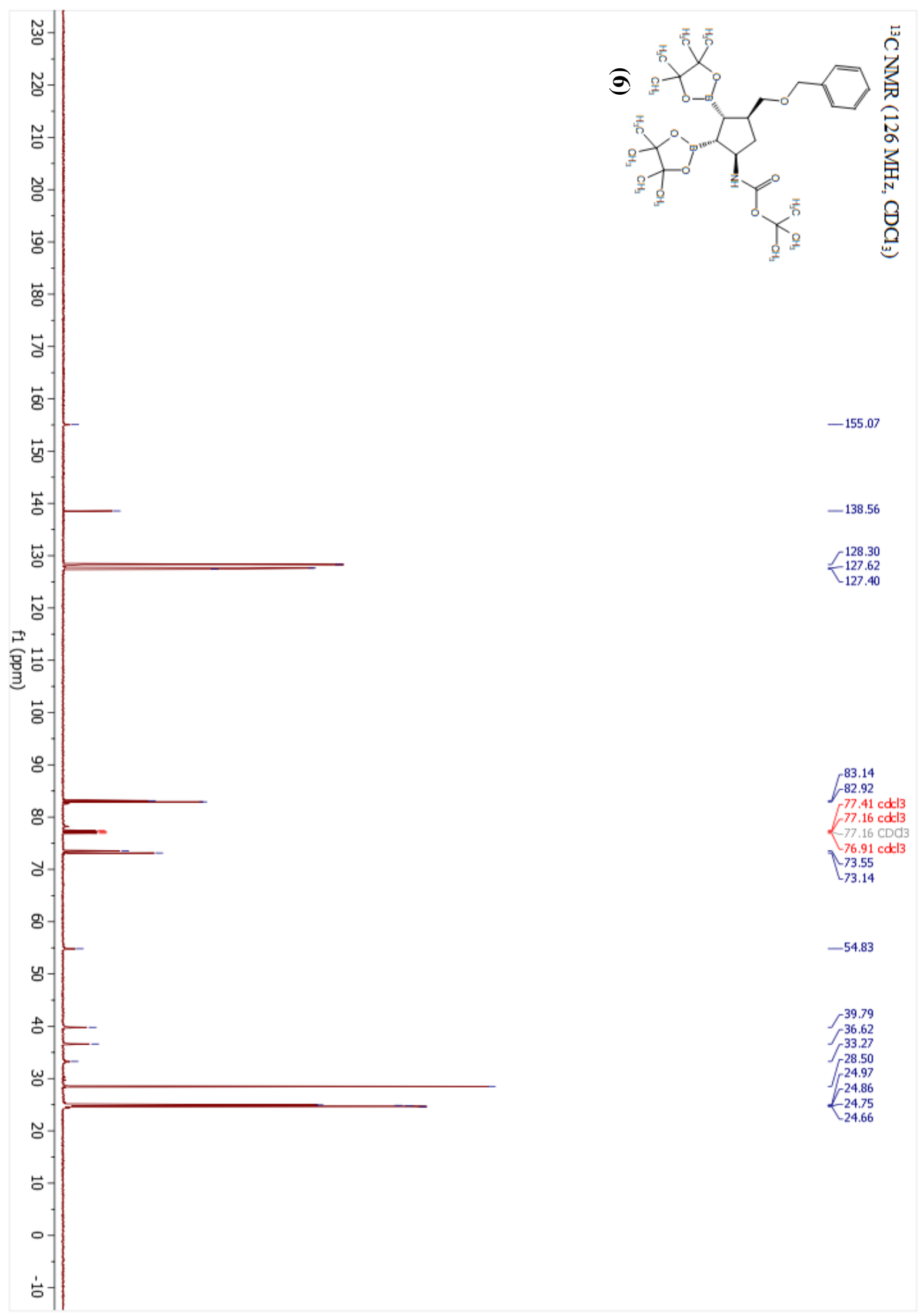


Vendola, Allais, Dechert Schmitt, Lee, Singer, and Morken Supplementary Information

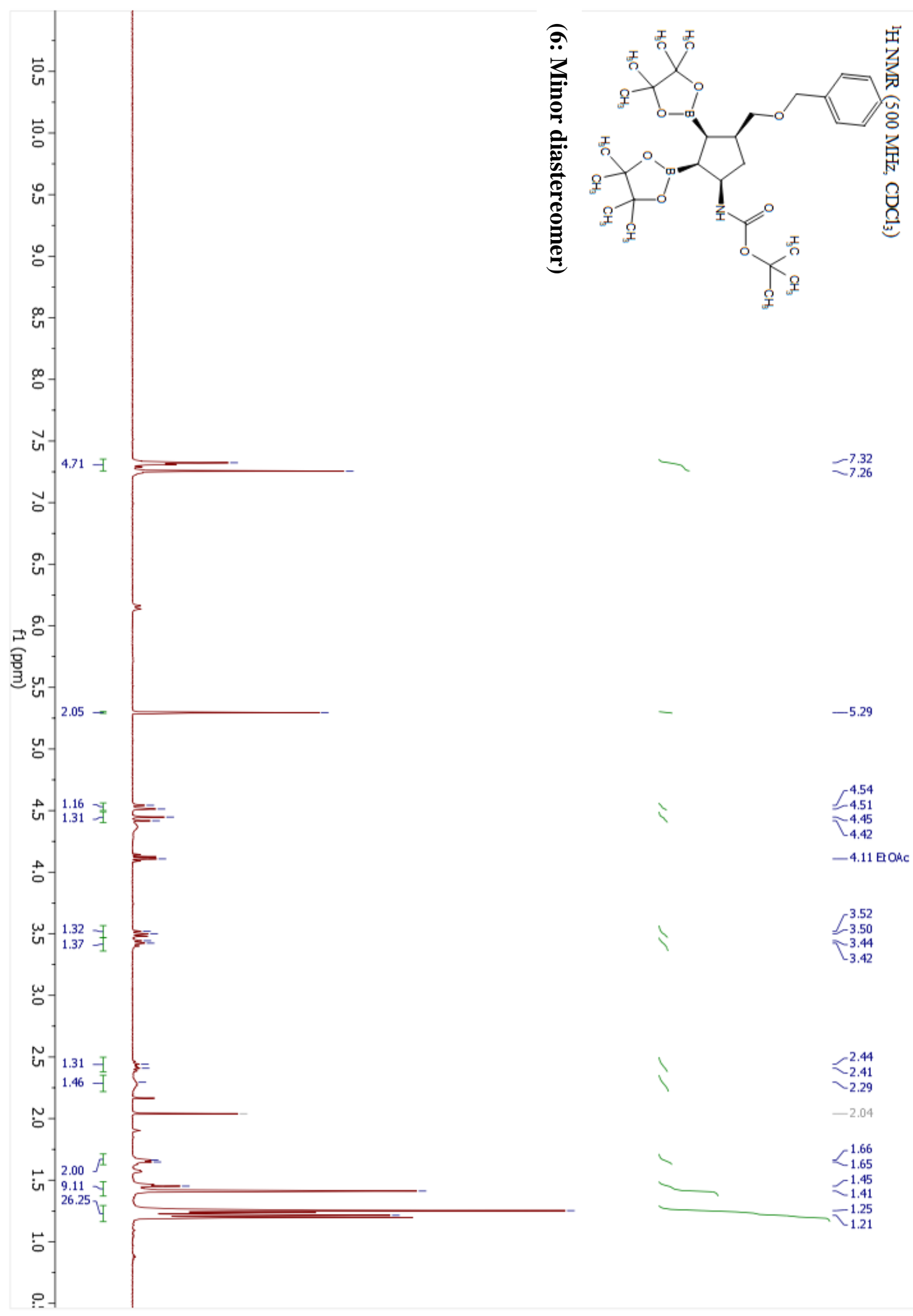


Vendola, Allais, Dechert Schmitt, Lee, Singer, and Morken Supplementary Information

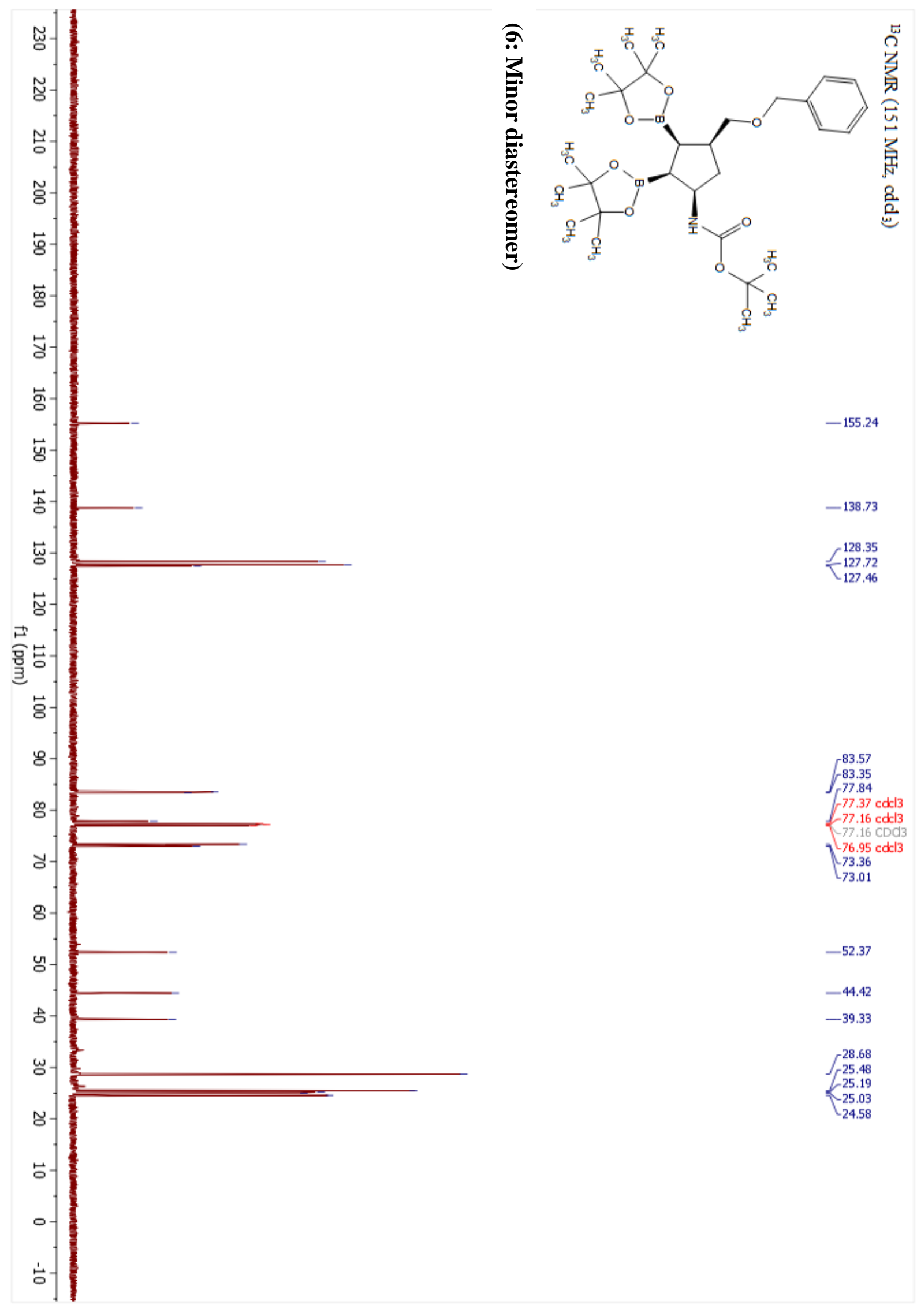


Vendola, Allais, Dechert Schmitt, Lee, Singer, and Morken Supplementary Information

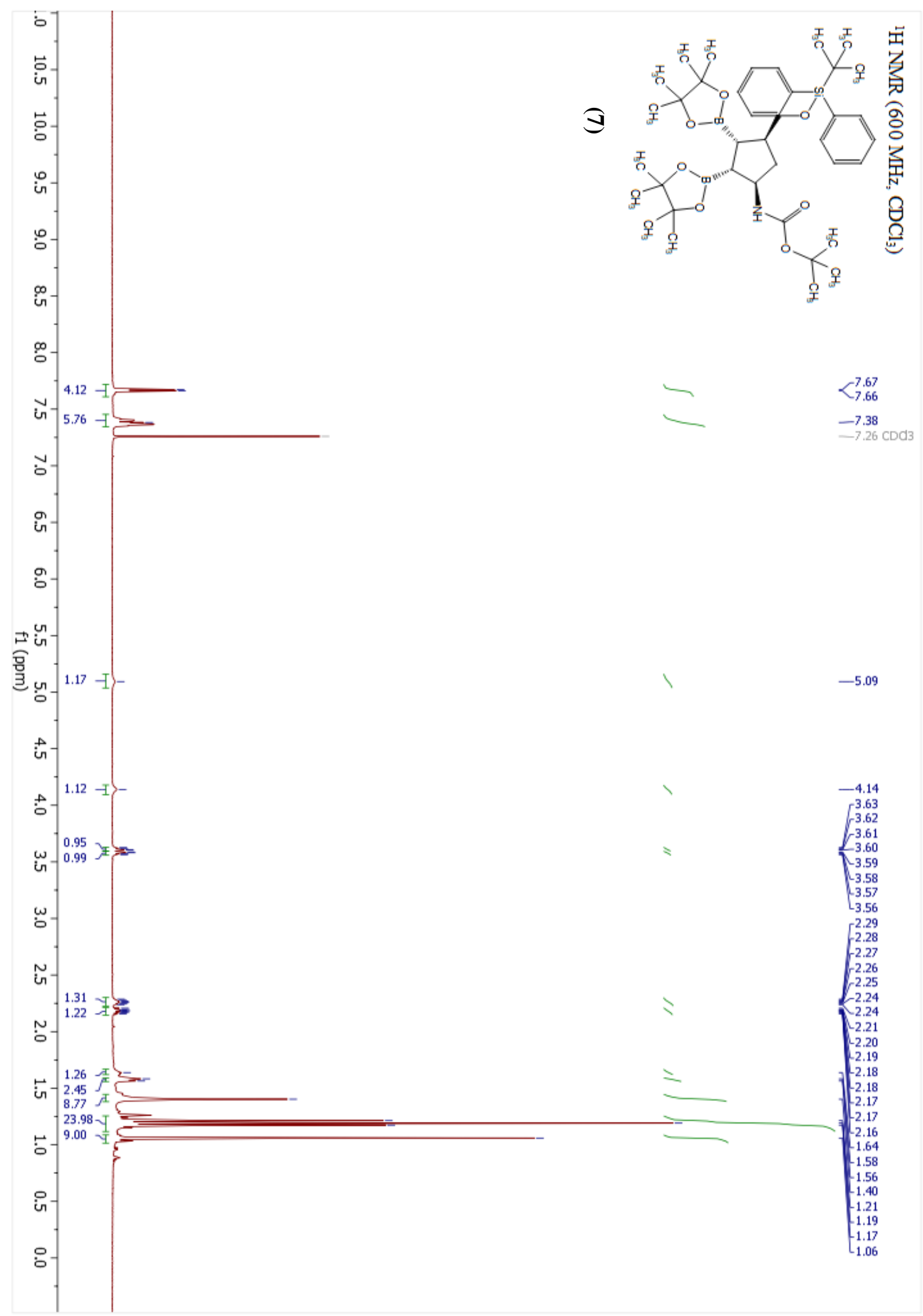


Vendola, Allais, Dechert Schmitt, Lee, Singer, and Morken Supplementary Information

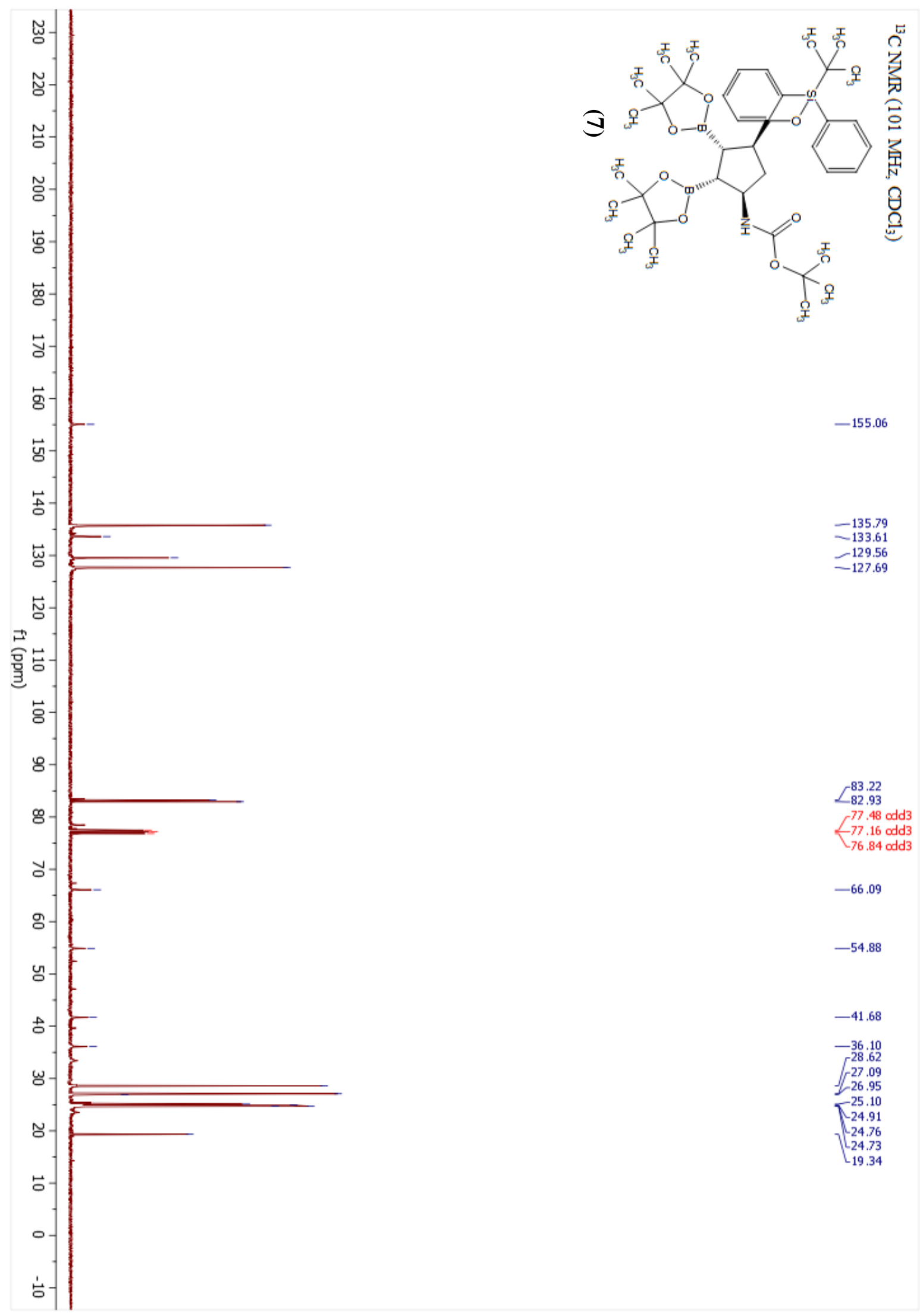


Vendola, Allais, Dechert Schmitt, Lee, Singer, and Morken Supplementary Information

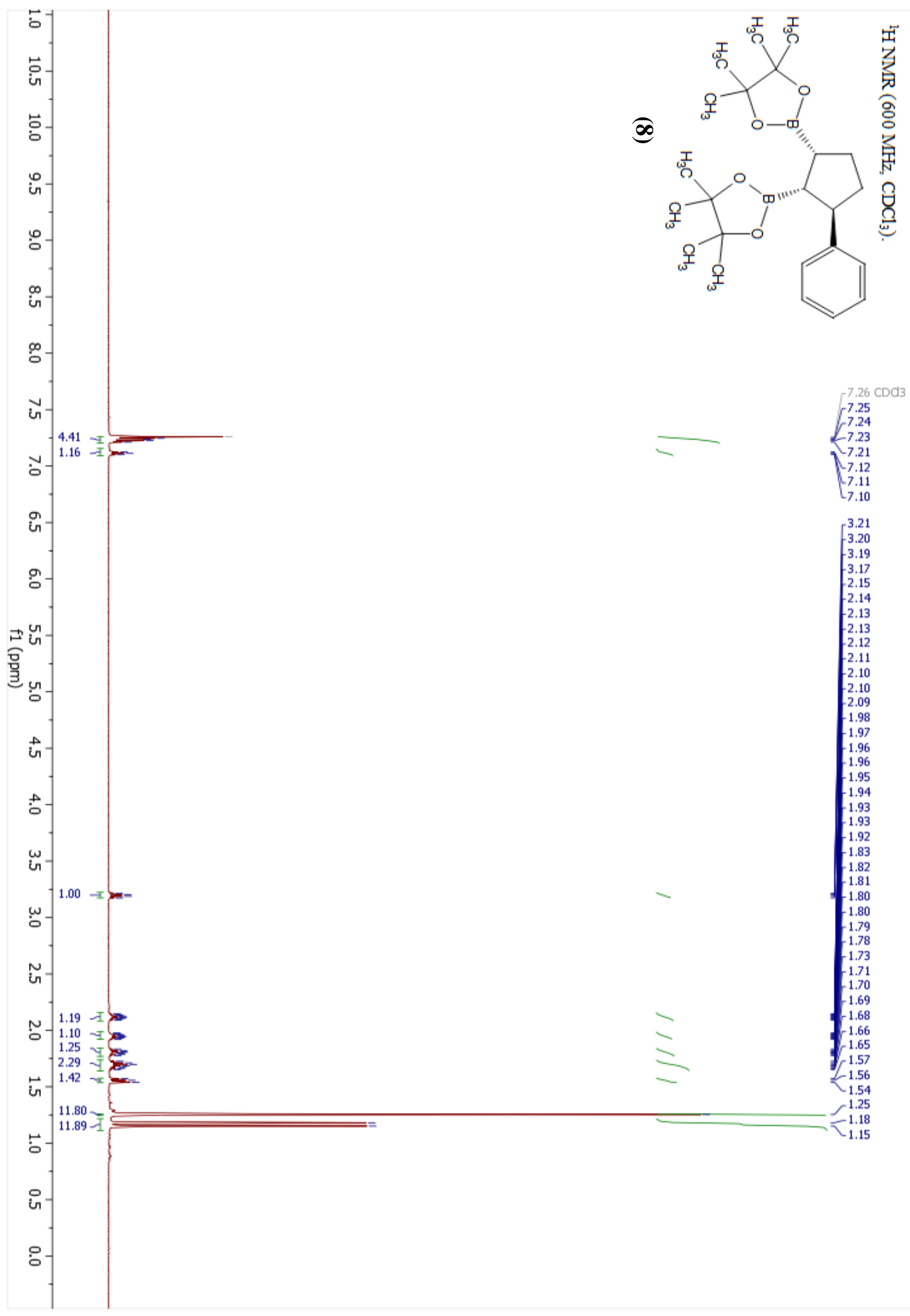


Vendola, Allais, Dechert Schmitt, Lee, Singer, and Morken Supplementary Information

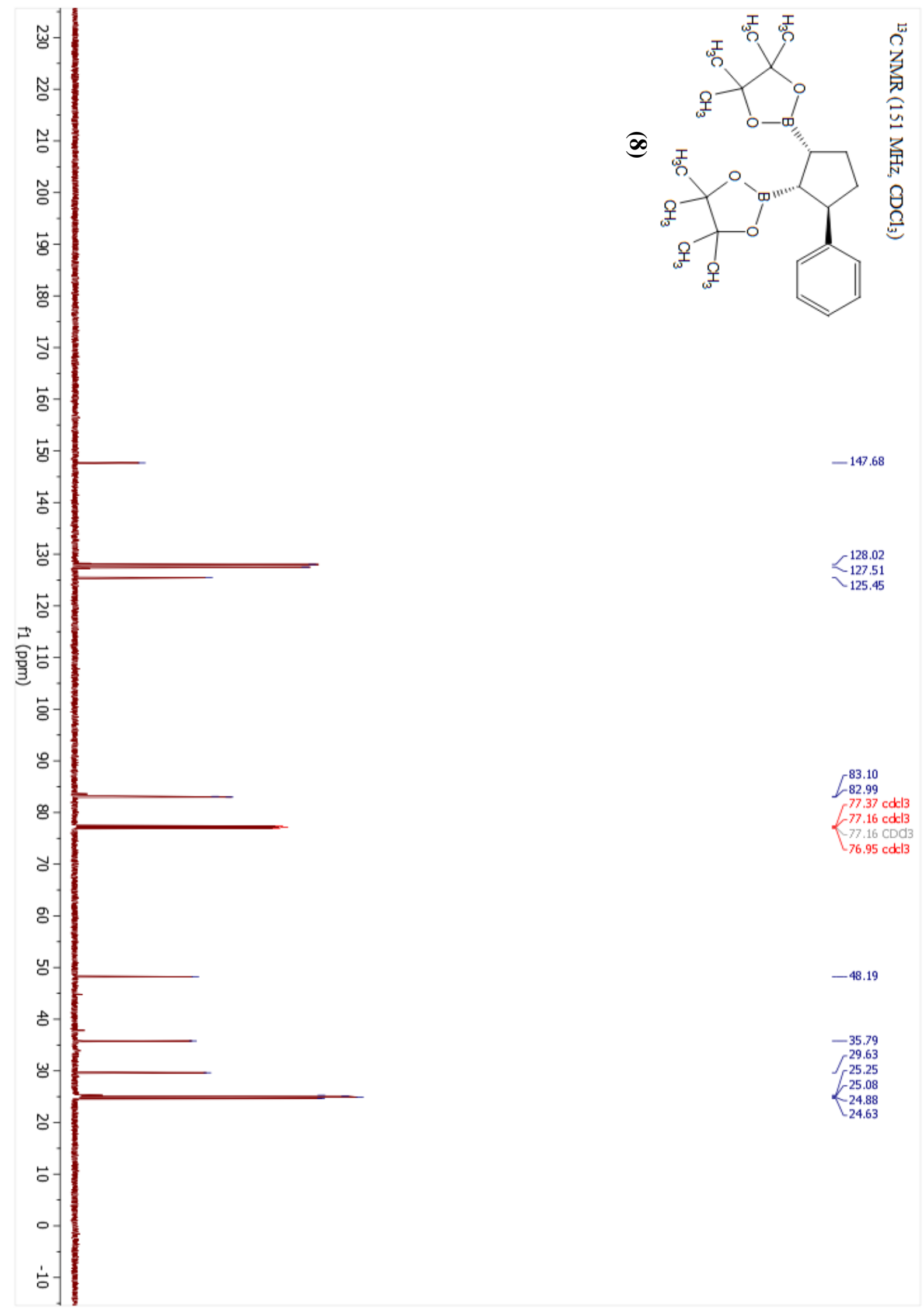


Vendola, Allais, Dechert Schmitt, Lee, Singer, and Morken Supplementary Information

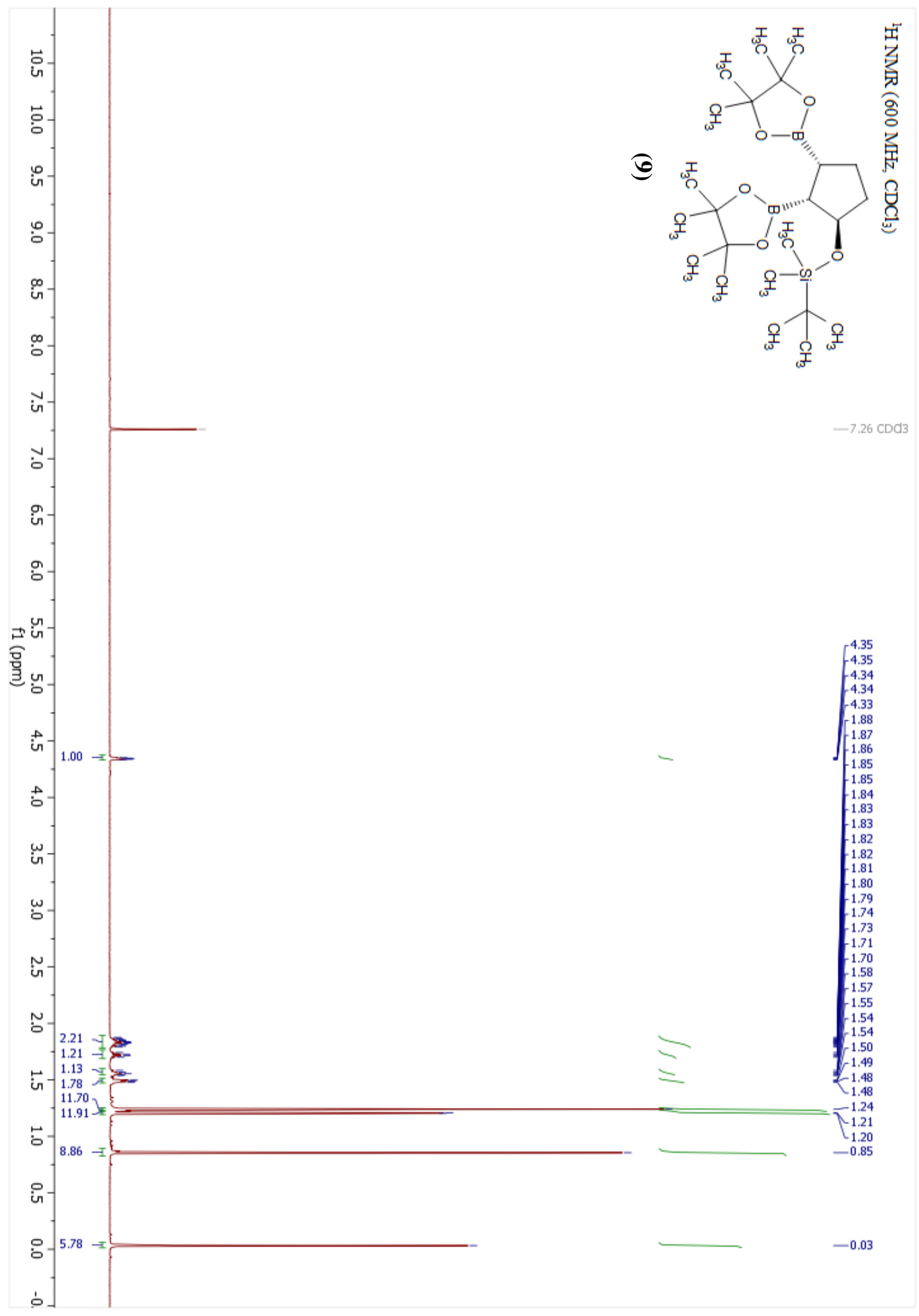


Vendola, Allais, Dechert Schmitt, Lee, Singer, and Morken Supplementary Information

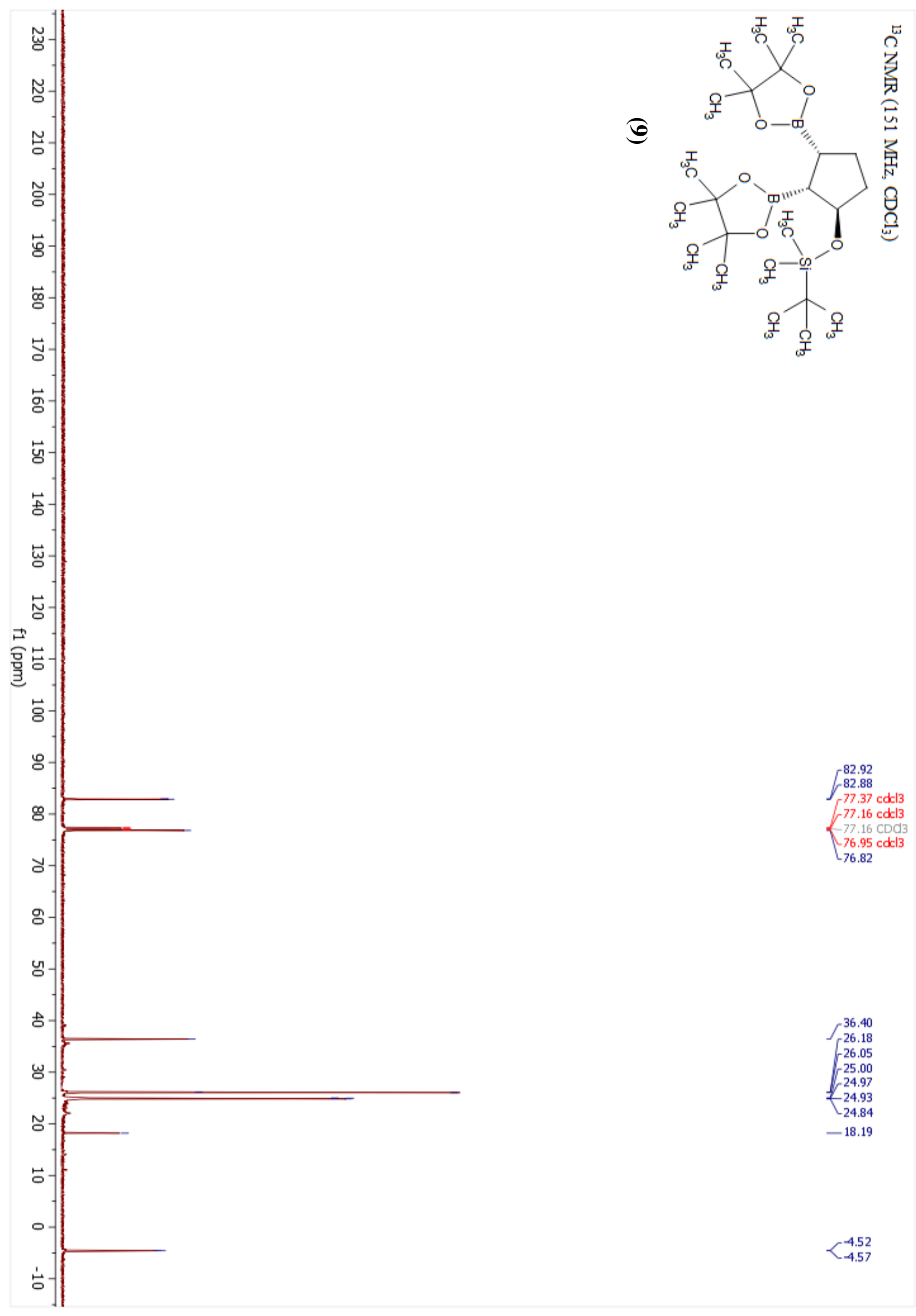


Vendola, Allais, Dechert Schmitt, Lee, Singer, and Morken Supplementary Information

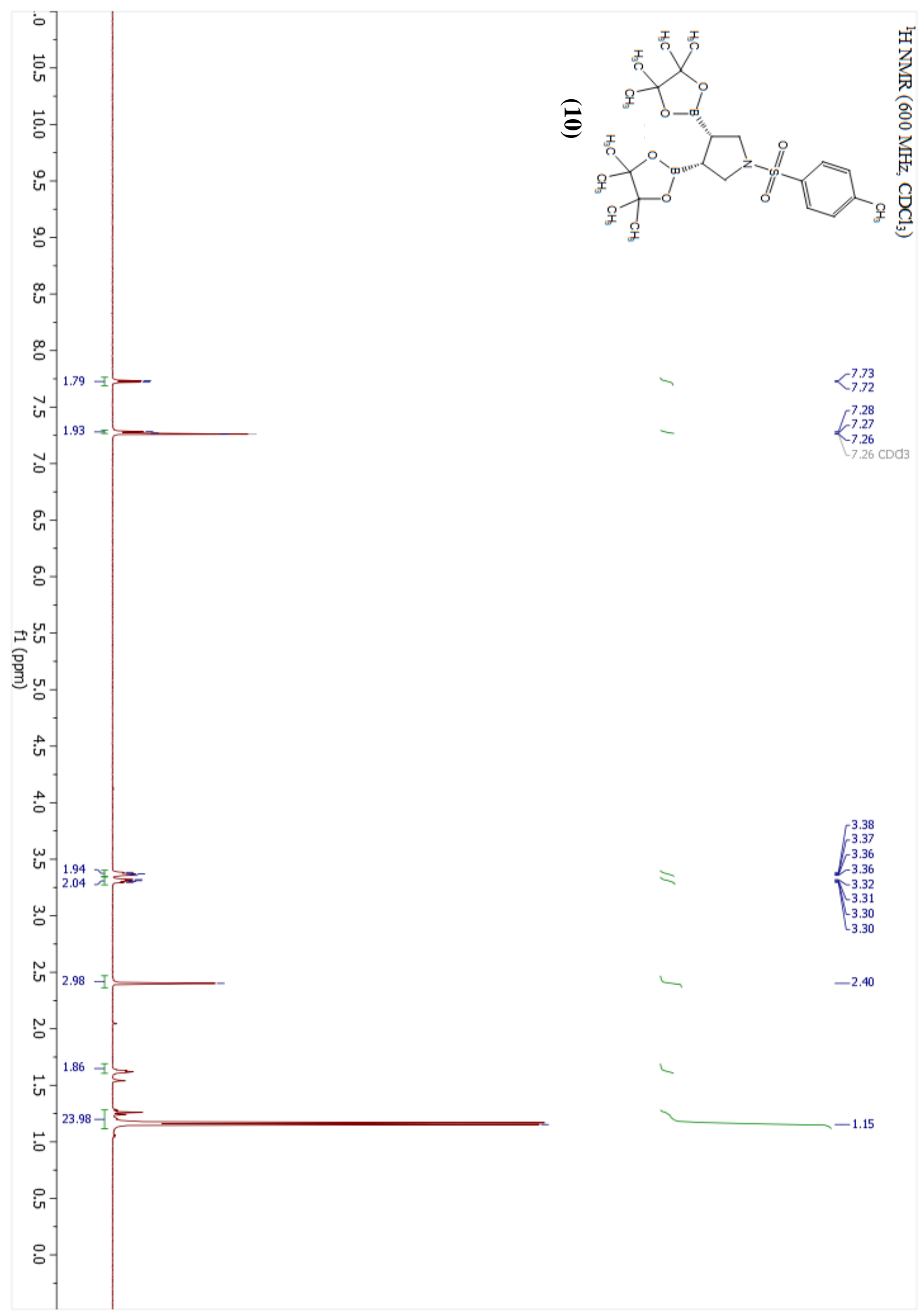


Vendola, Allais, Dechert Schmitt, Lee, Singer, and Morken Supplementary Information

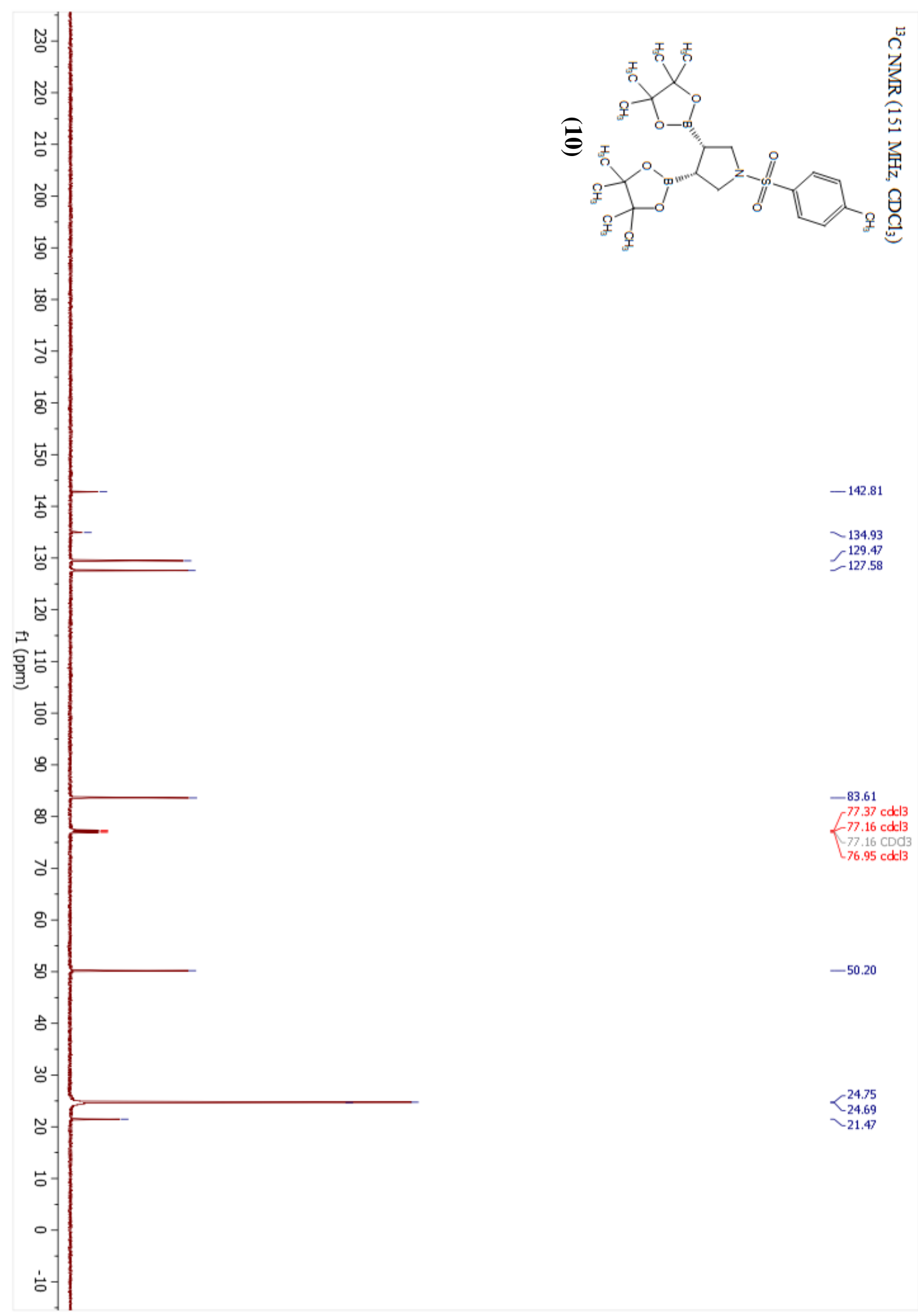


Vendola, Allais, Dechert Schmitt, Lee, Singer, and Morken Supplementary Information

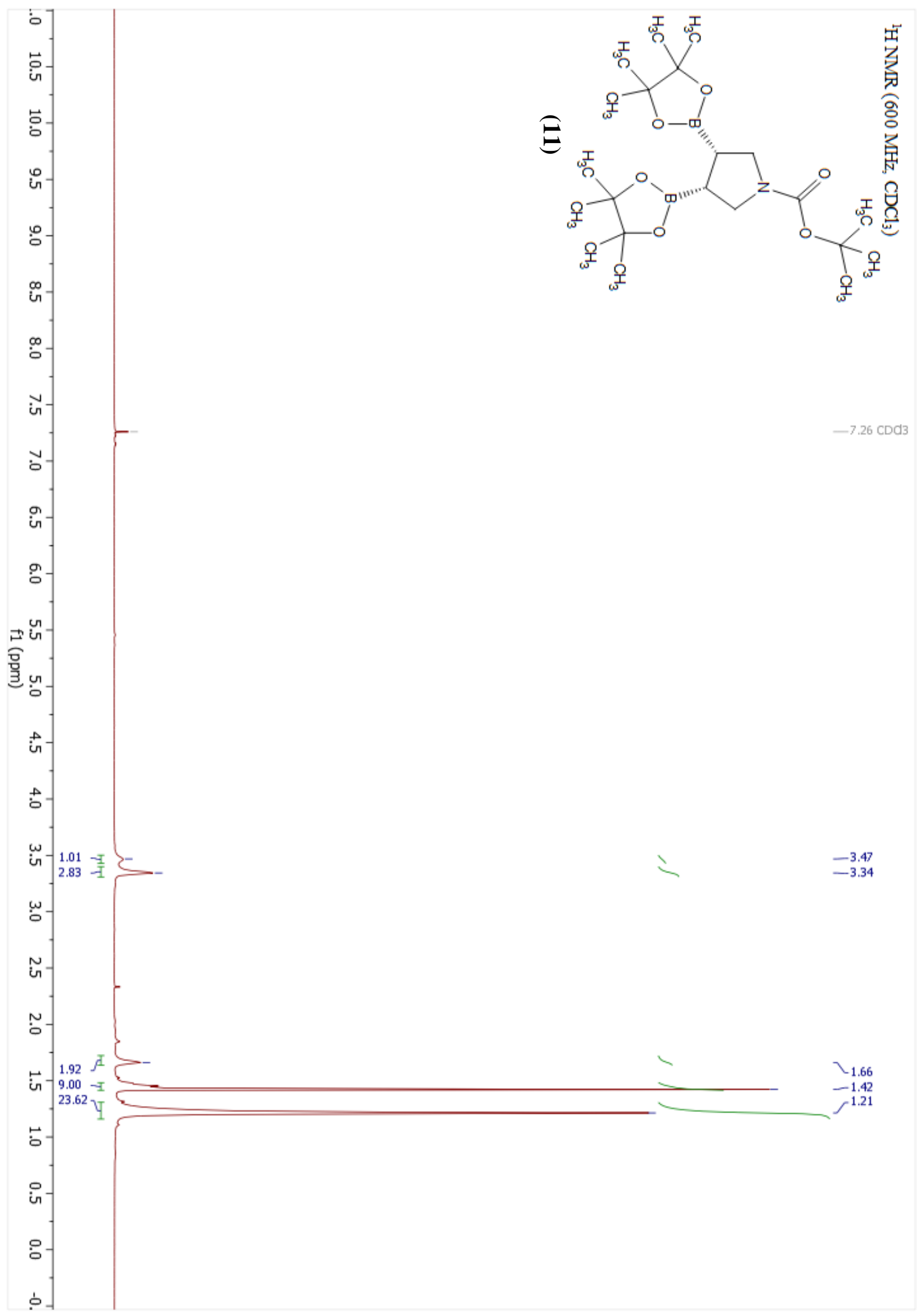


Vendola, Allais, Dechert Schmitt, Lee, Singer, and Morken Supplementary Information

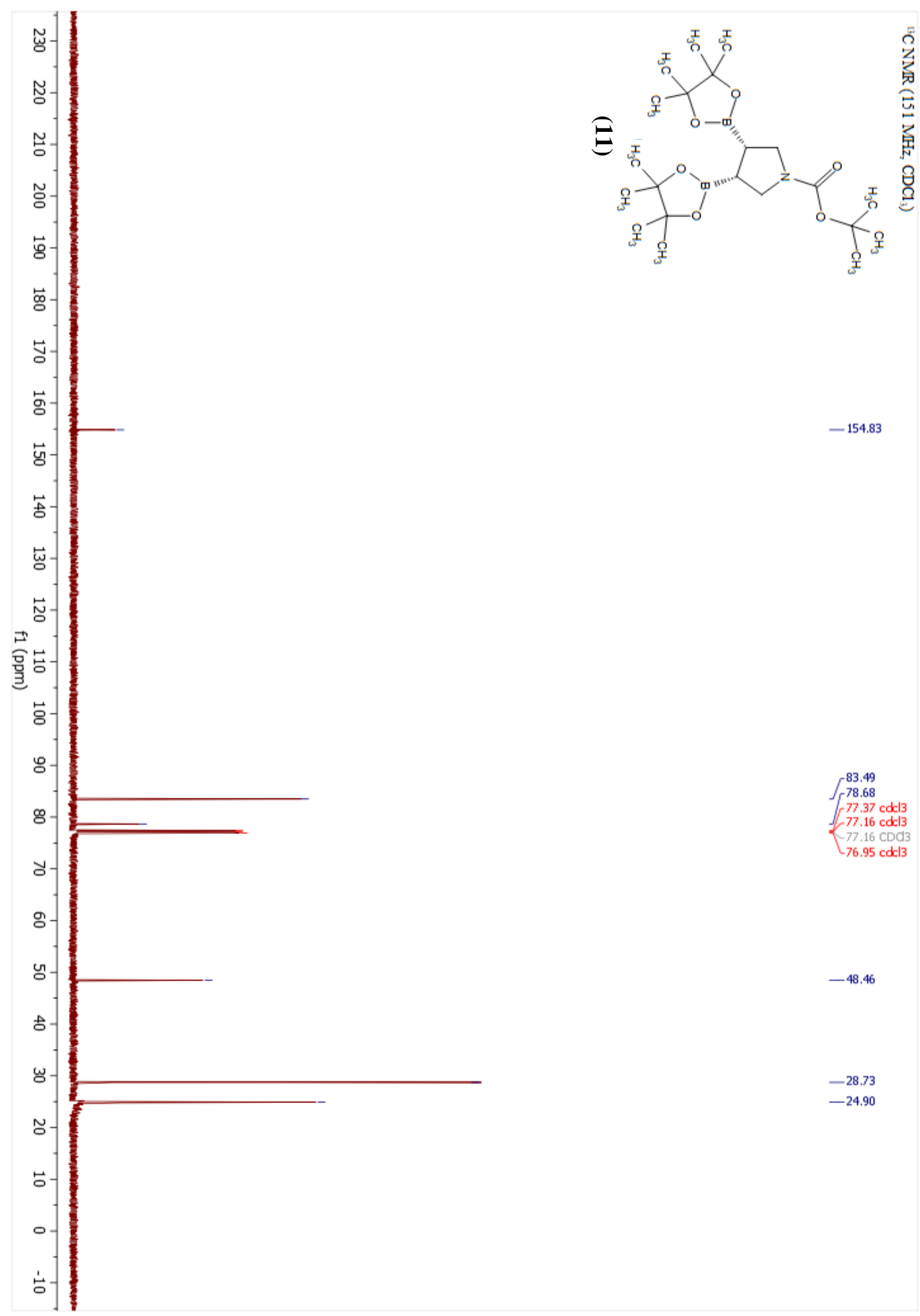


Vendola, Allais, Dechert Schmitt, Lee, Singer, and Morken Supplementary Information

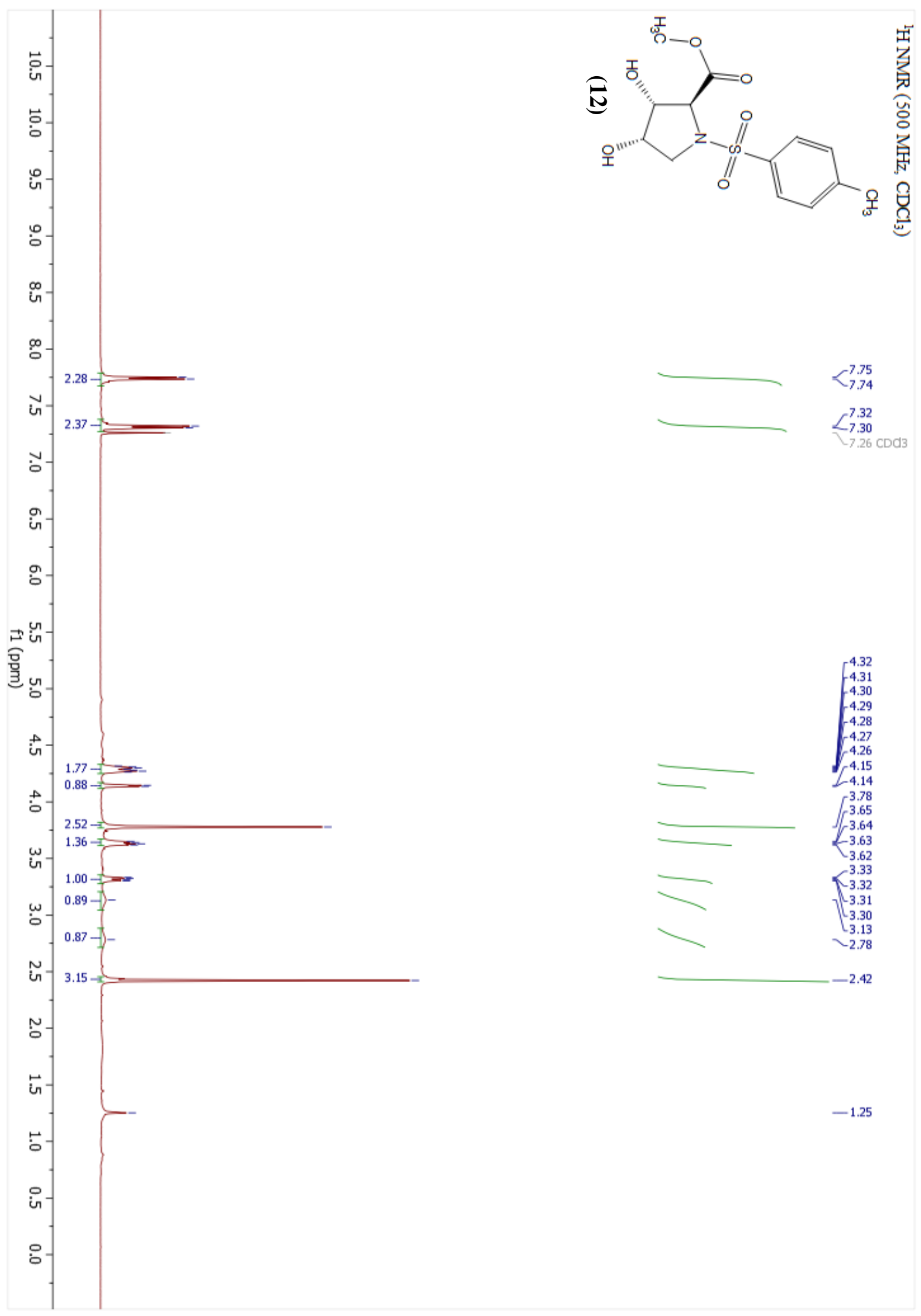


Vendola, Allais, Dechert Schmitt, Lee, Singer, and Morken Supplementary Information

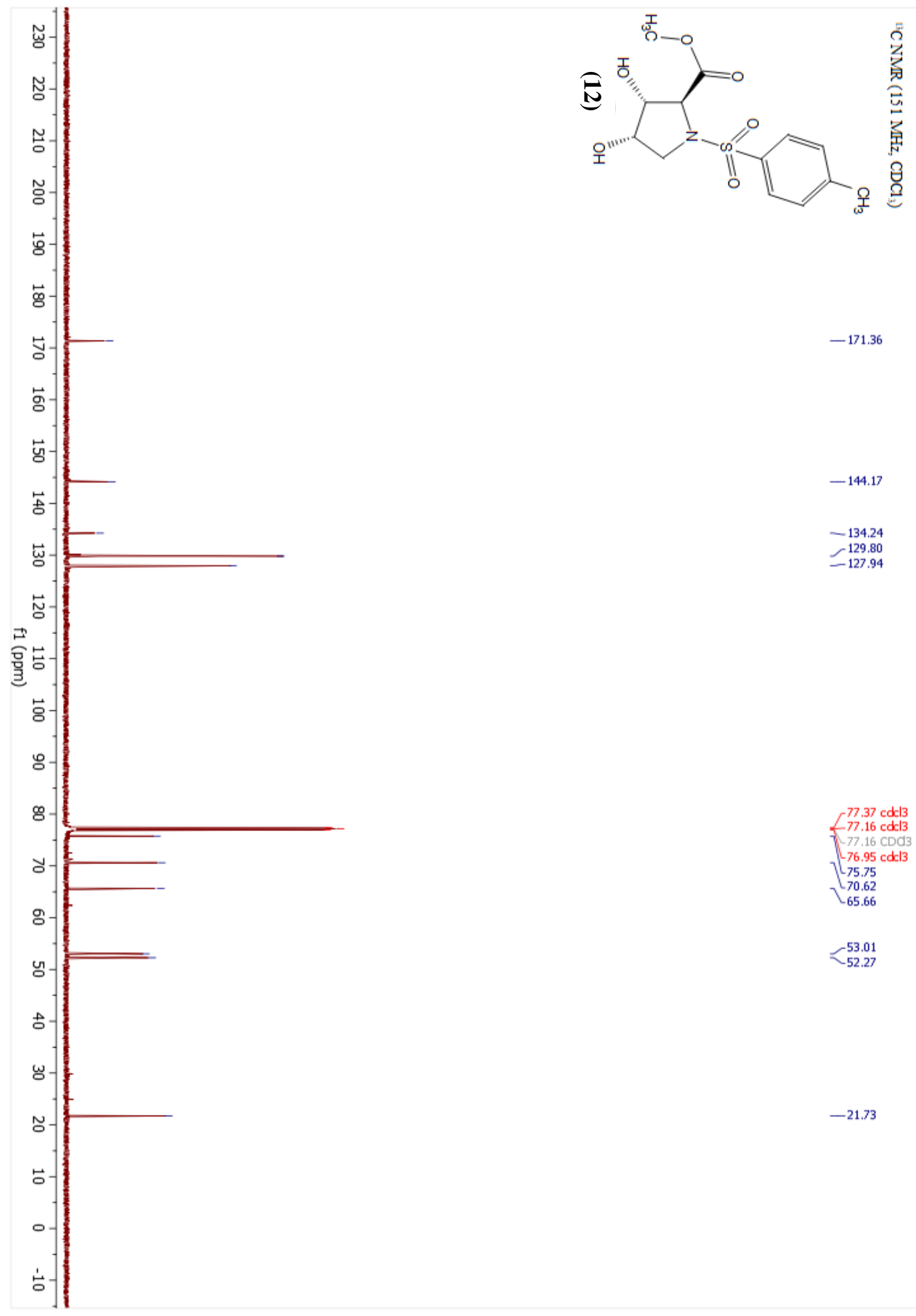


Vendola, Allais, Dechert Schmitt, Lee, Singer, and Morken Supplementary Information

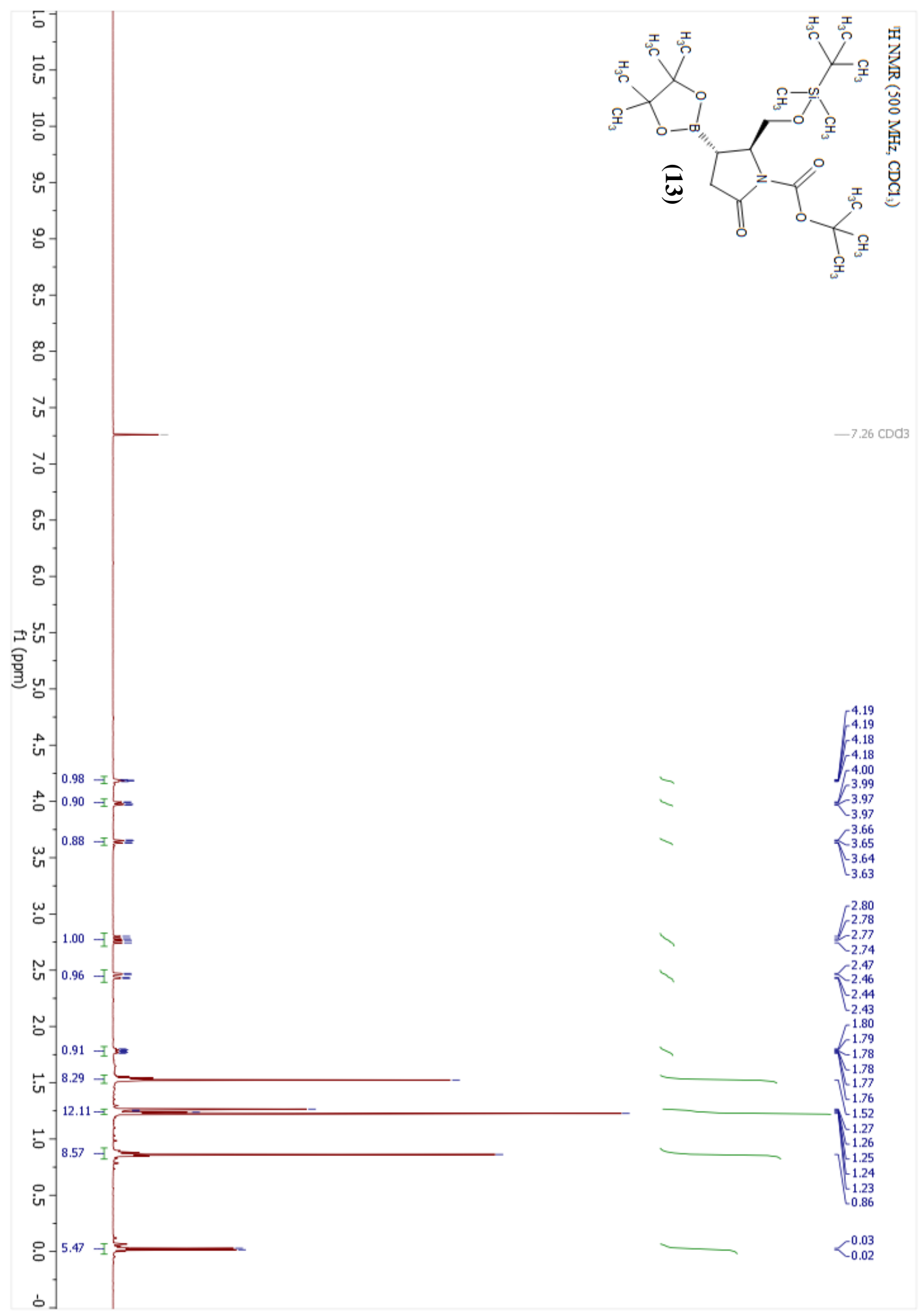


Vendola, Allais, Dechert Schmitt, Lee, Singer, and Morken Supplementary Information

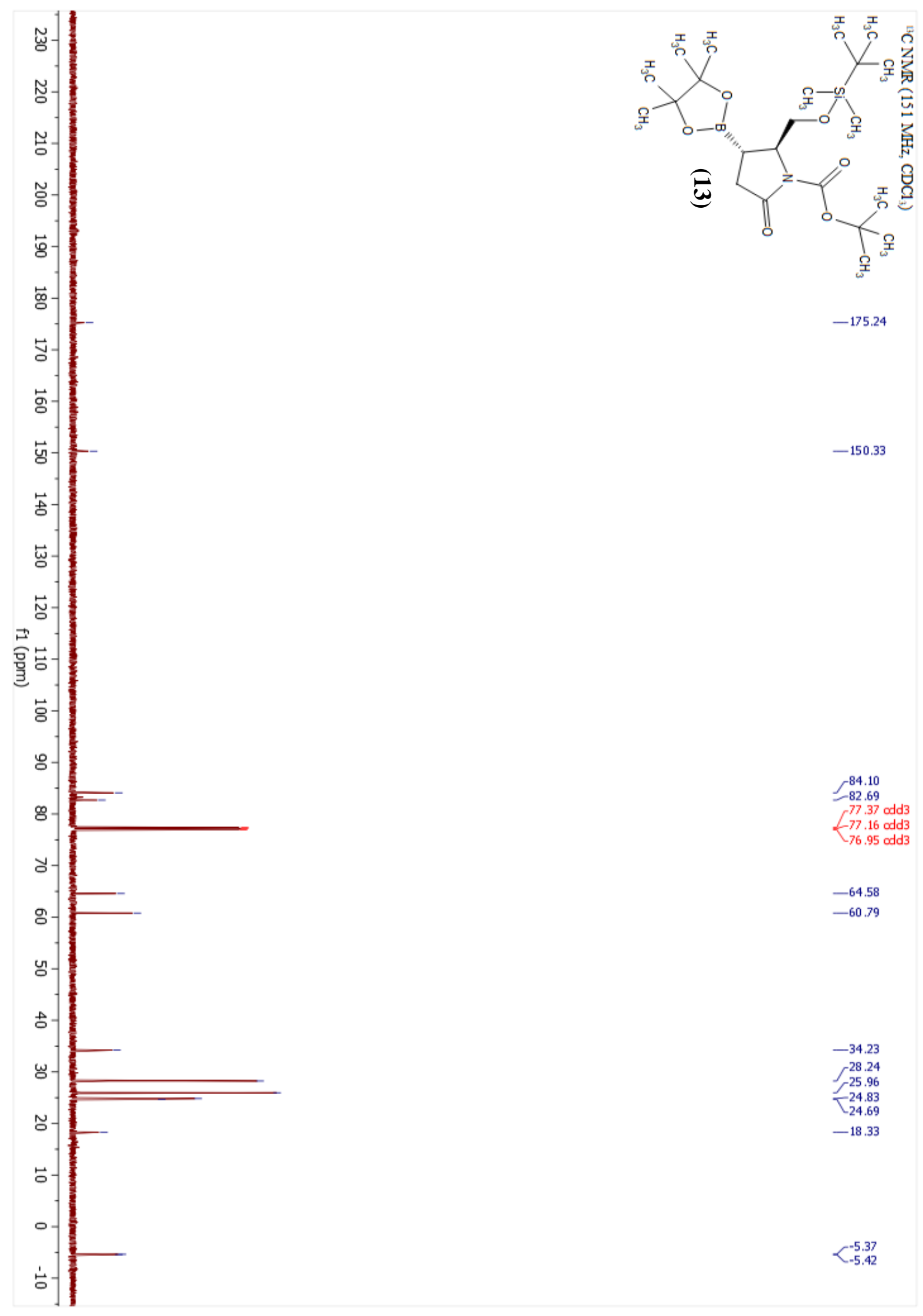


Vendola, Allais, Dechert Schmitt, Lee, Singer, and Morken Supplementary Information

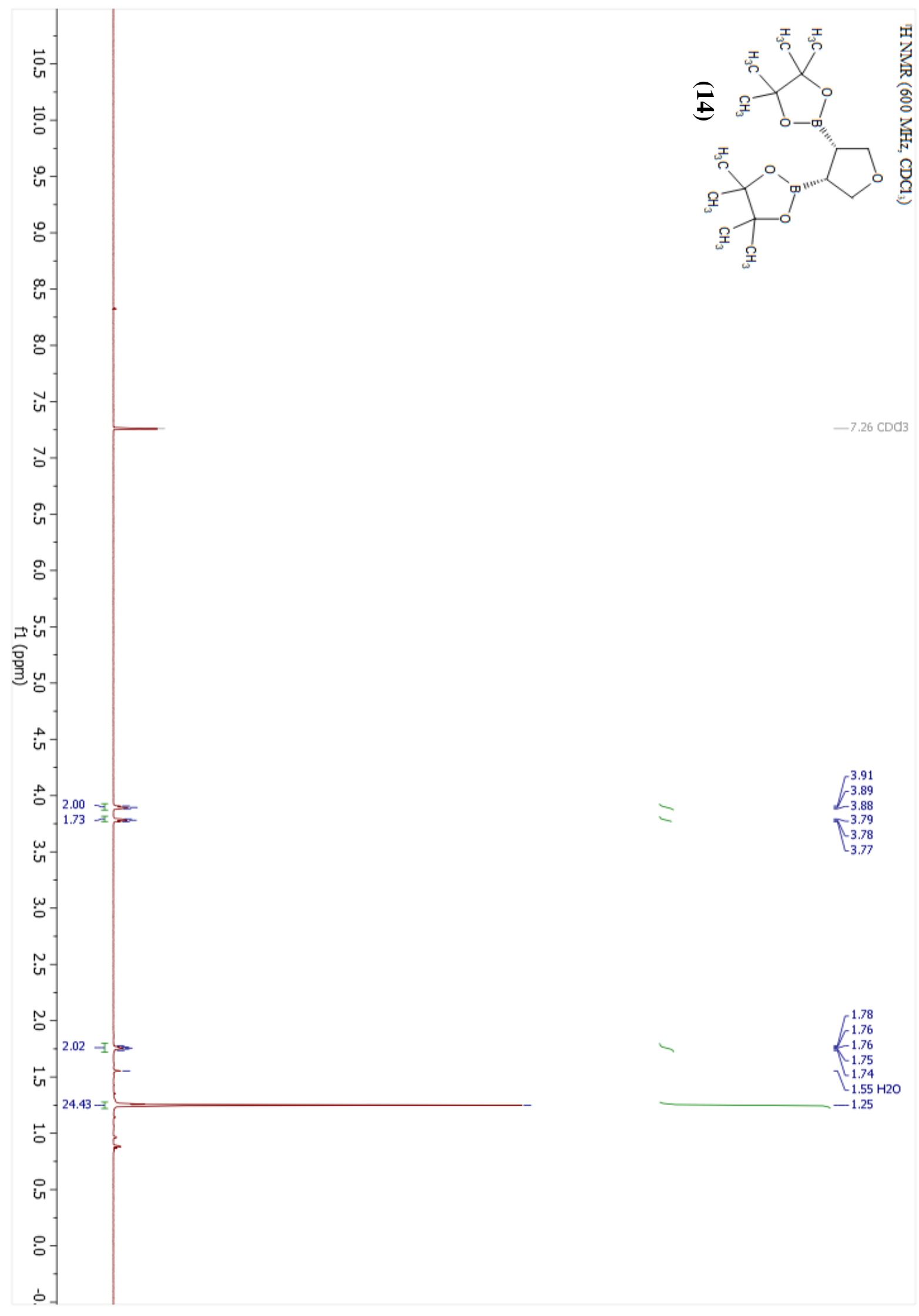


Vendola, Allais, Dechert Schmitt, Lee, Singer, and Morken Supplementary Information

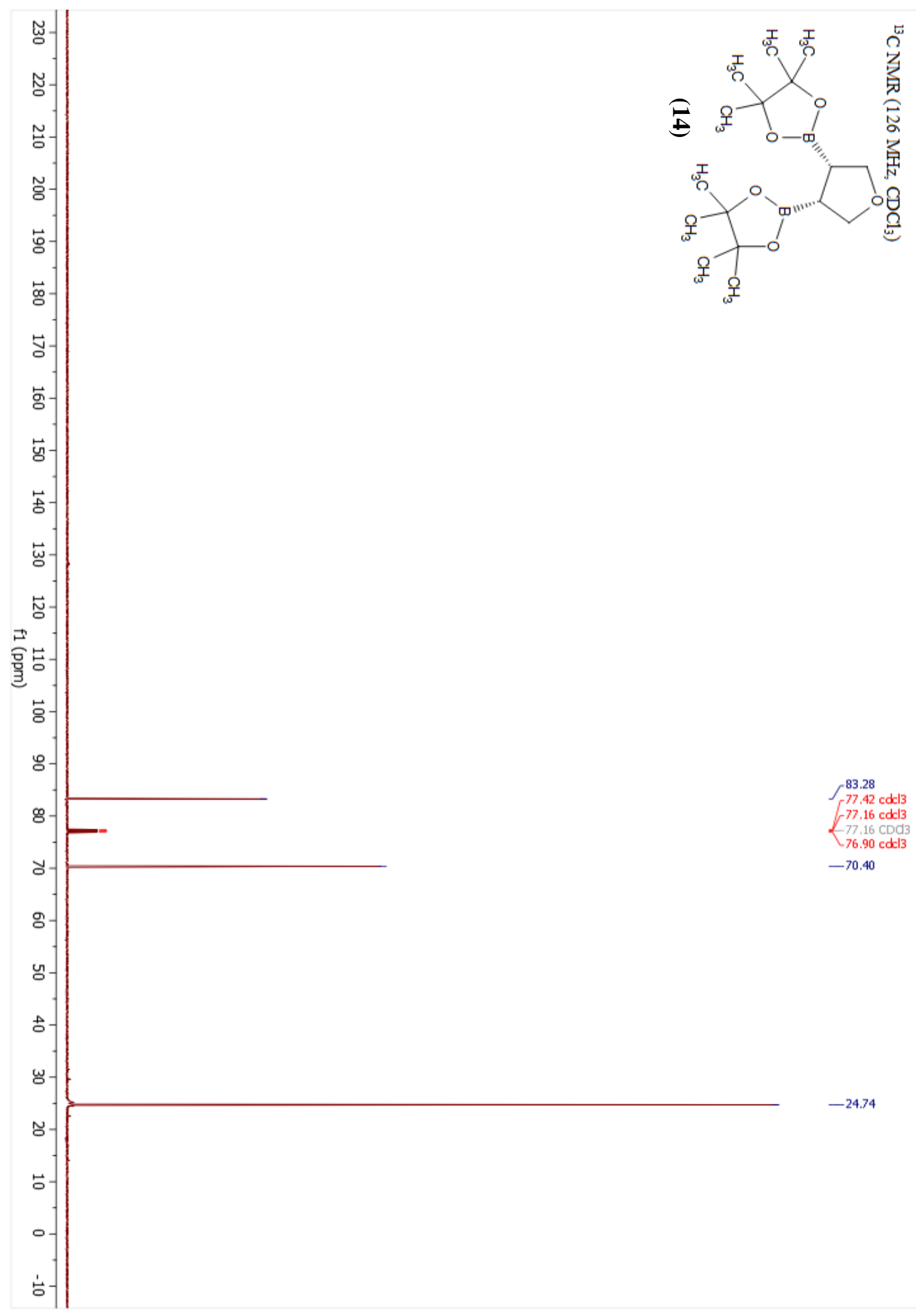


Vendola, Allais, Dechert Schmitt, Lee, Singer, and Morken Supplementary Information

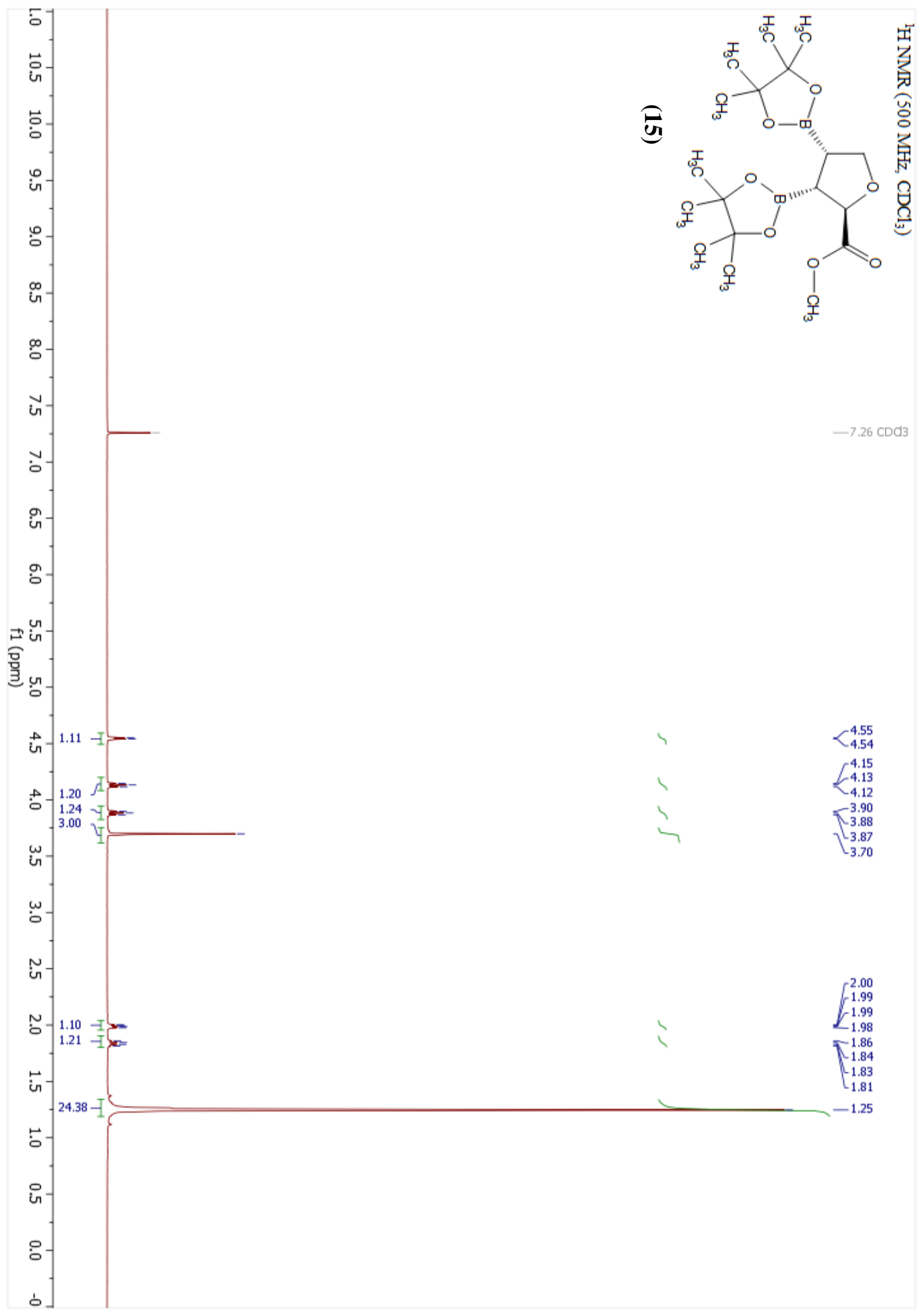


Vendola, Allais, Dechert Schmitt, Lee, Singer, and Morken Supplementary Information

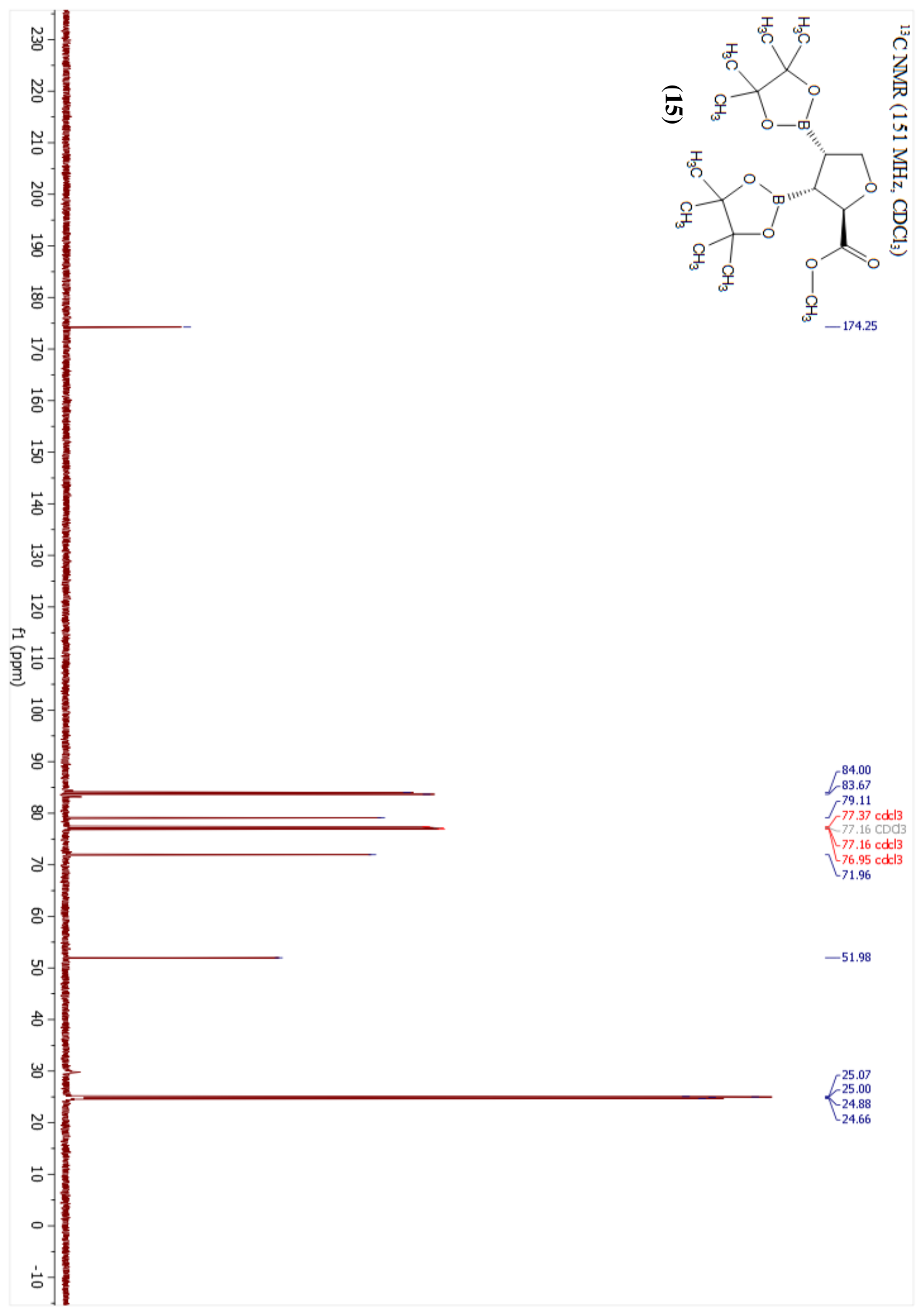


Vendola, Allais, Dechert Schmitt, Lee, Singer, and Morken Supplementary Information

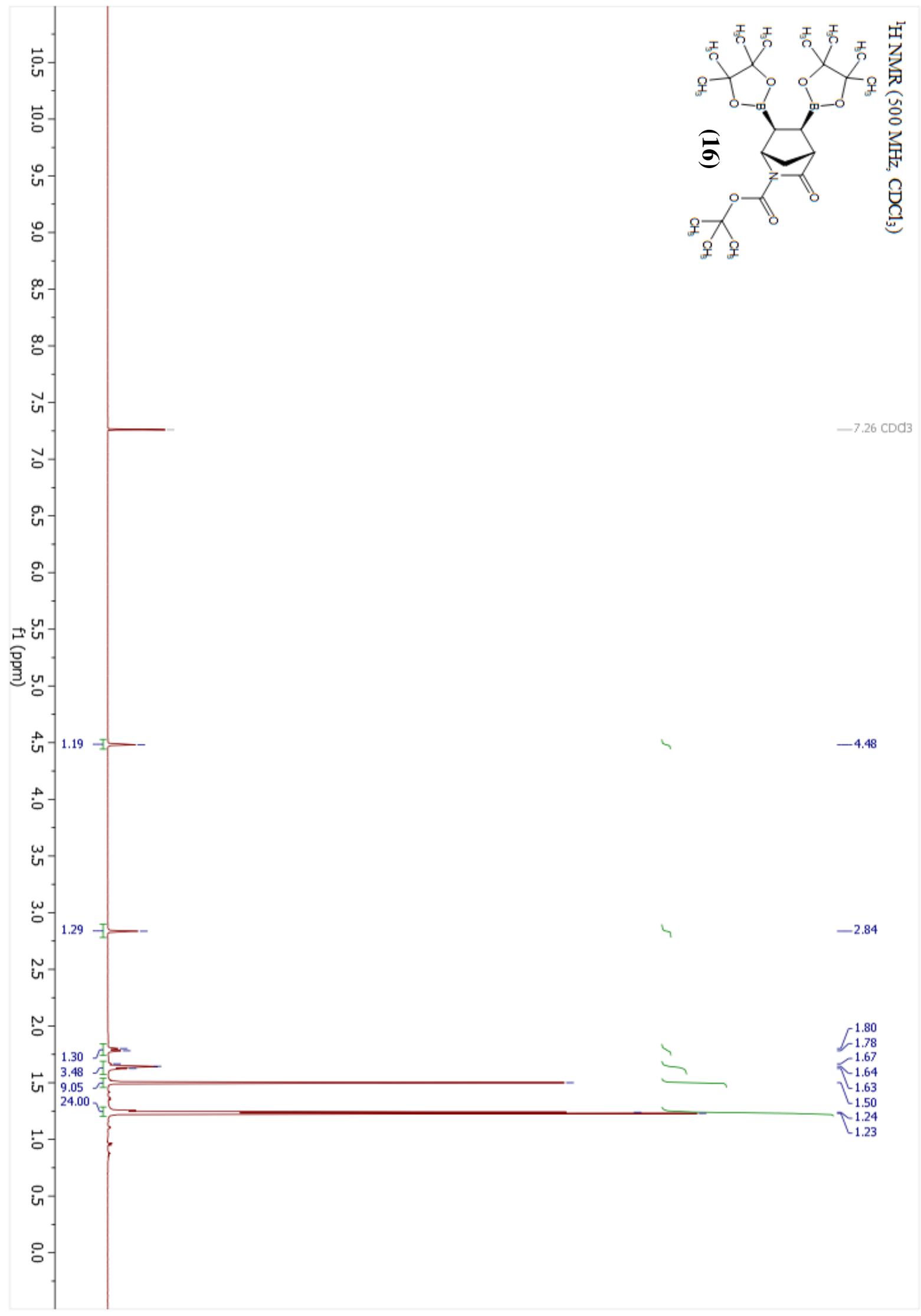


Vendola, Allais, Dechert Schmitt, Lee, Singer, and Morken Supplementary Information

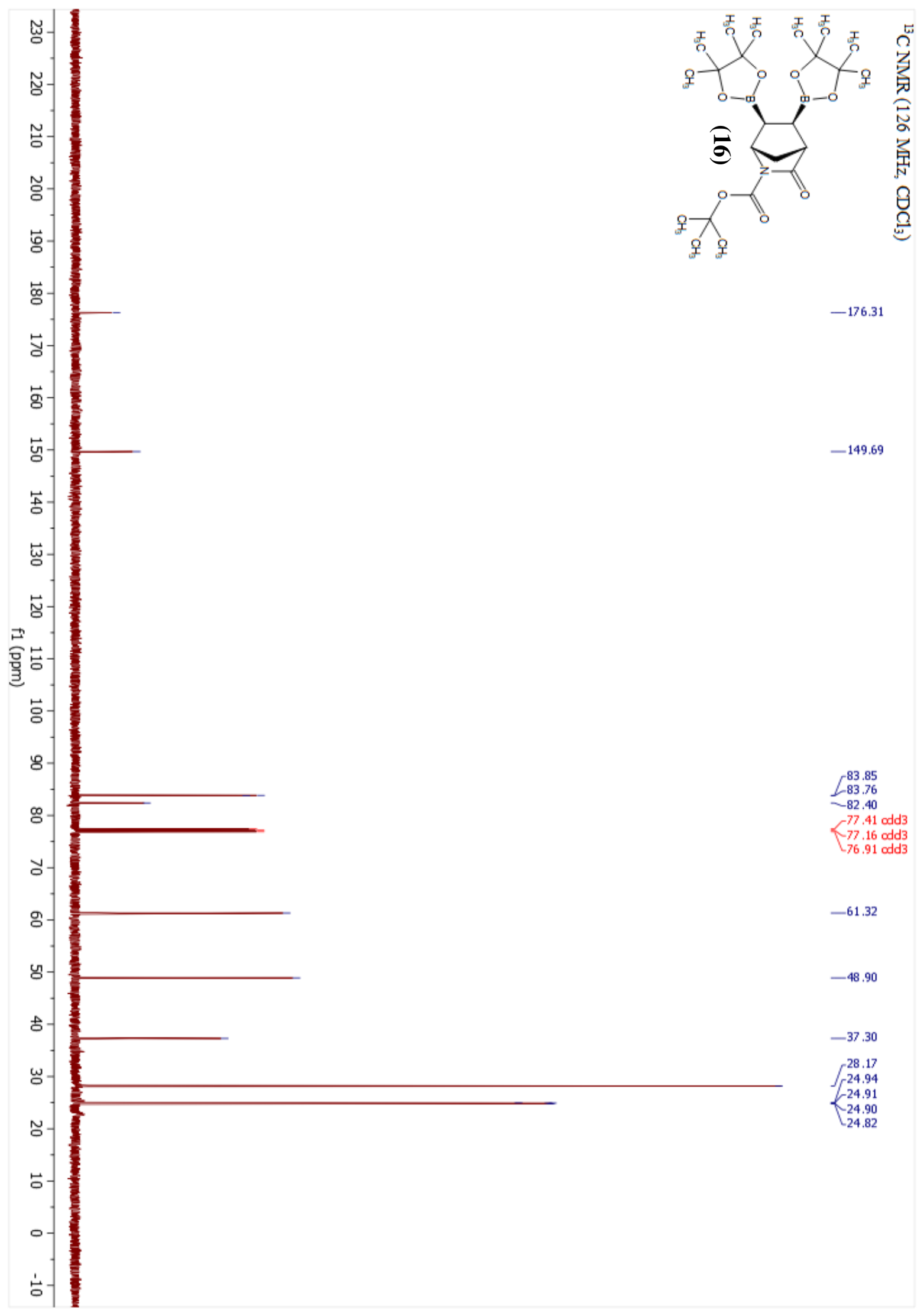


Vendola, Allais, Dechert Schmitt, Lee, Singer, and Morken Supplementary Information

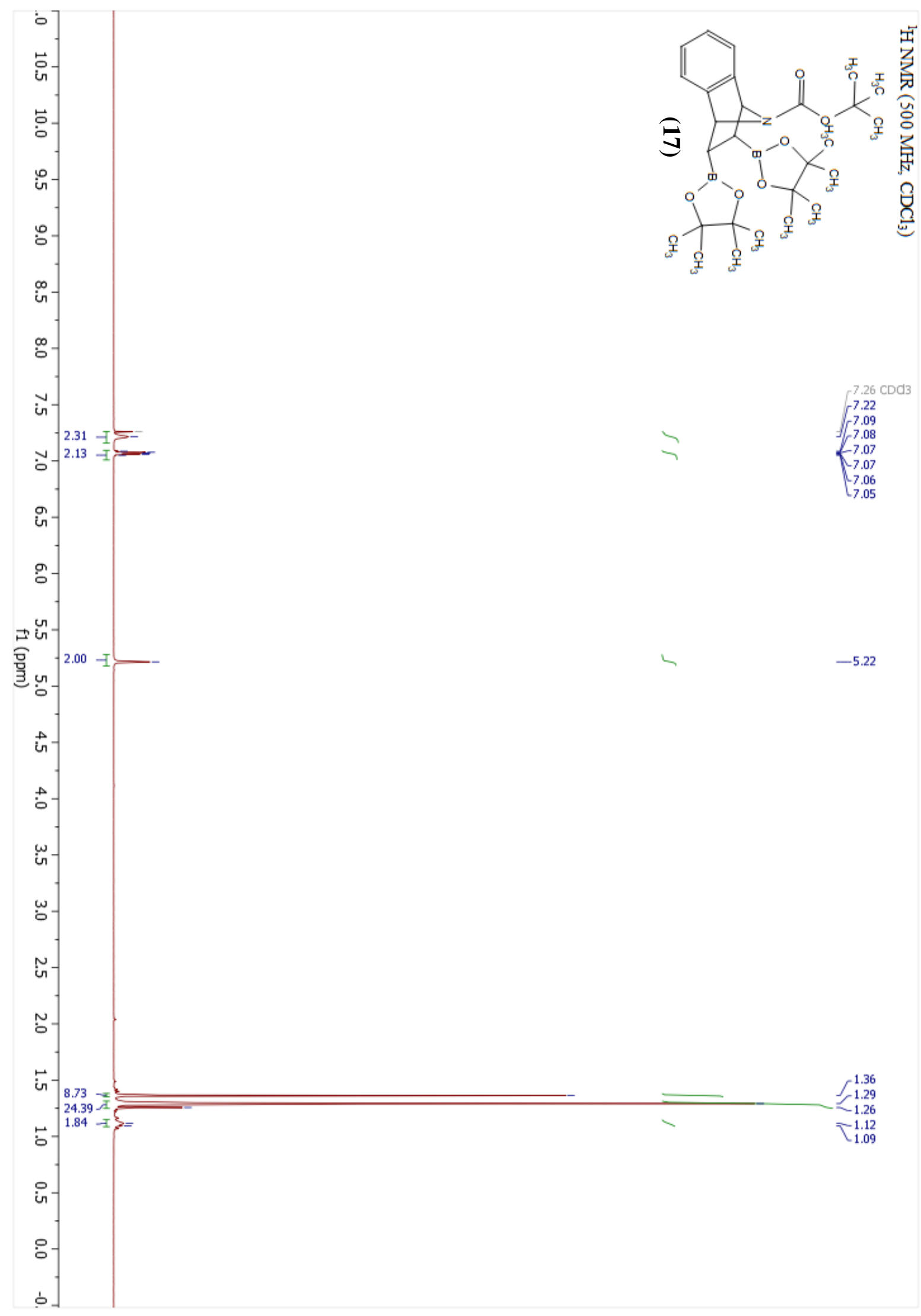


Vendola, Allais, Dechert Schmitt, Lee, Singer, and Morken Supplementary Information

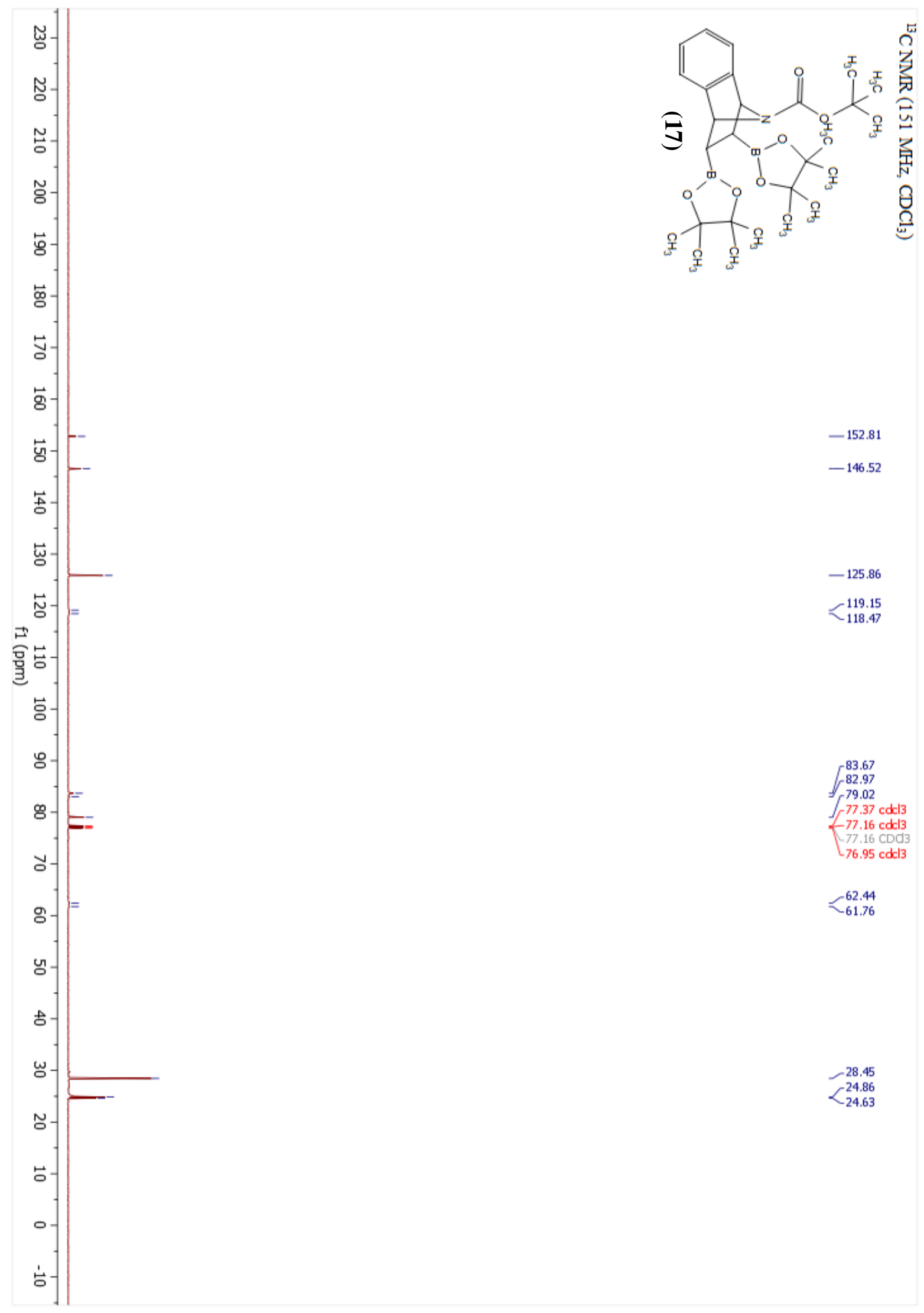


Vendola, Allais, Dechert Schmitt, Lee, Singer, and Morken Supplementary Information

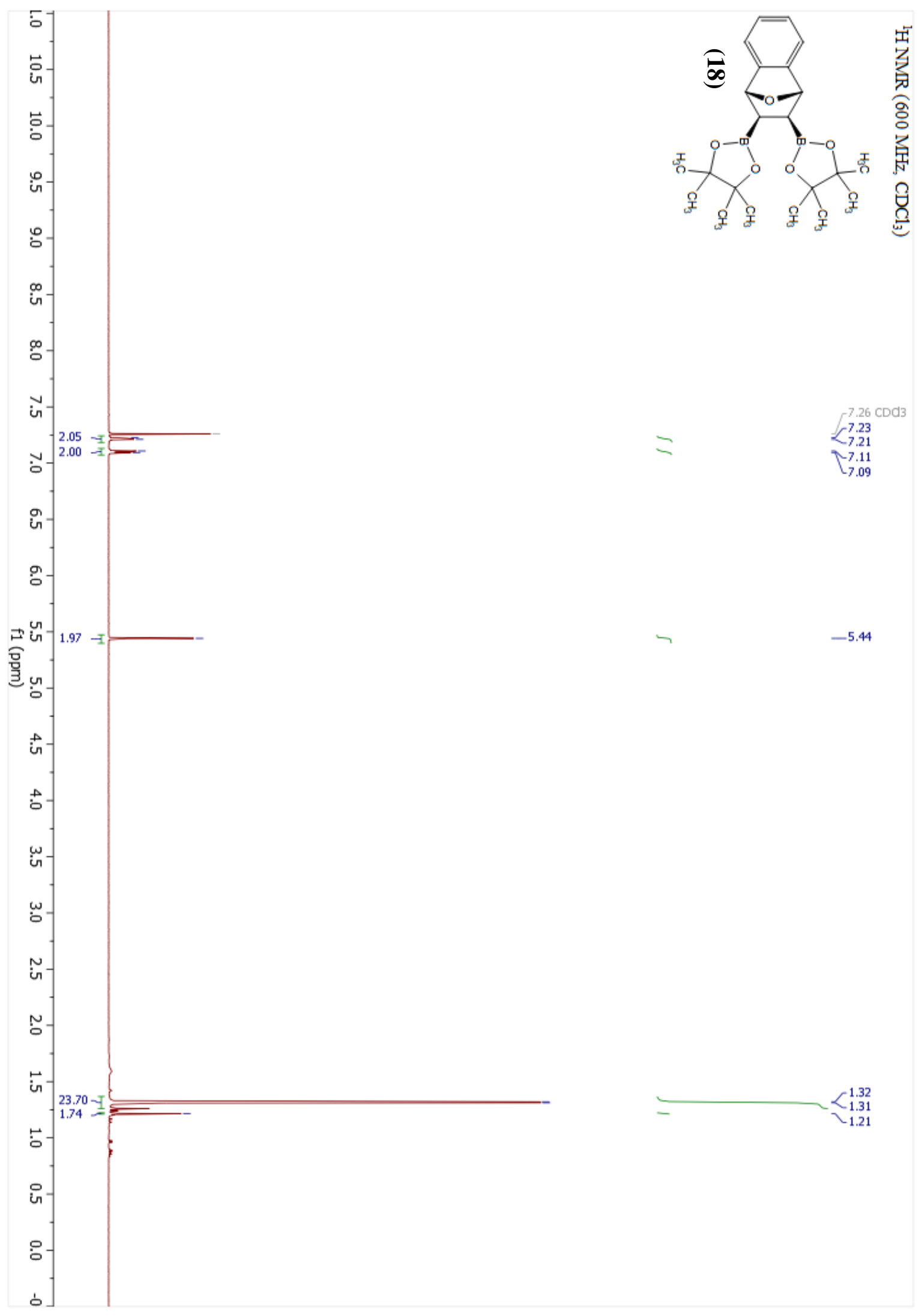


Vendola, Allais, Dechert Schmitt, Lee, Singer, and Morken Supplementary Information

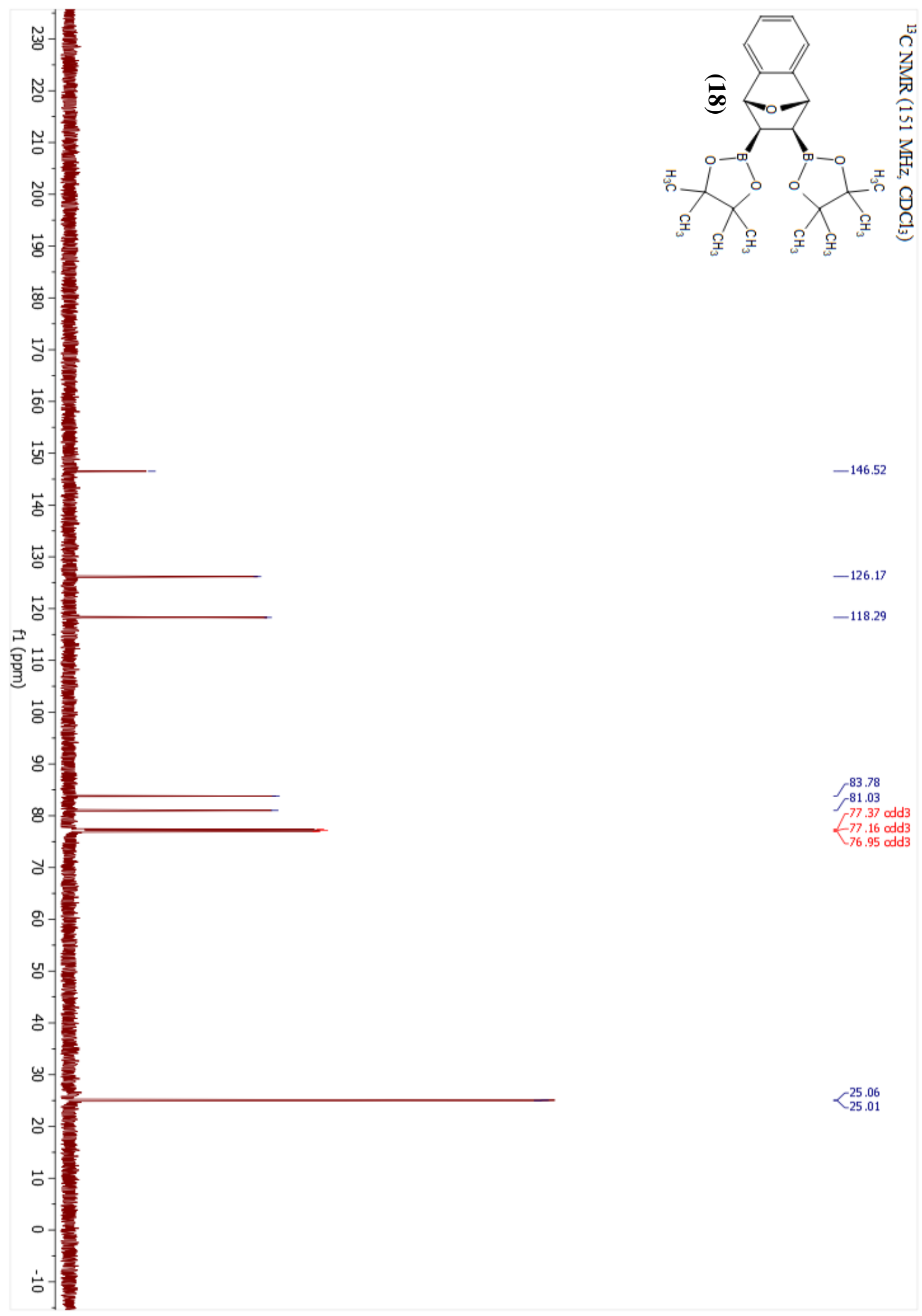


Vendola, Allais, Dechert Schmitt, Lee, Singer, and Morken Supplementary Information

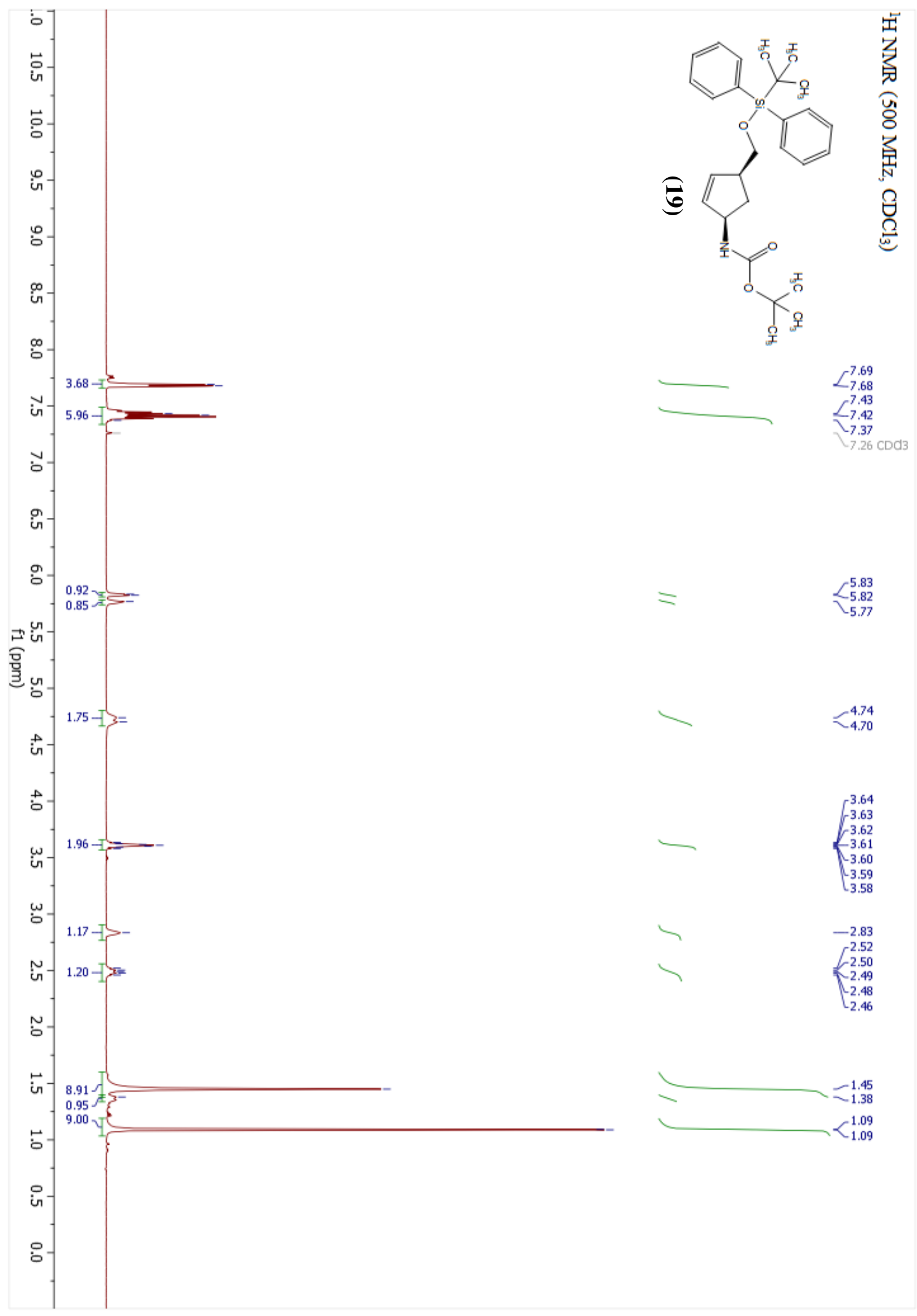


Vendola, Allais, Dechert Schmitt, Lee, Singer, and Morken Supplementary Information

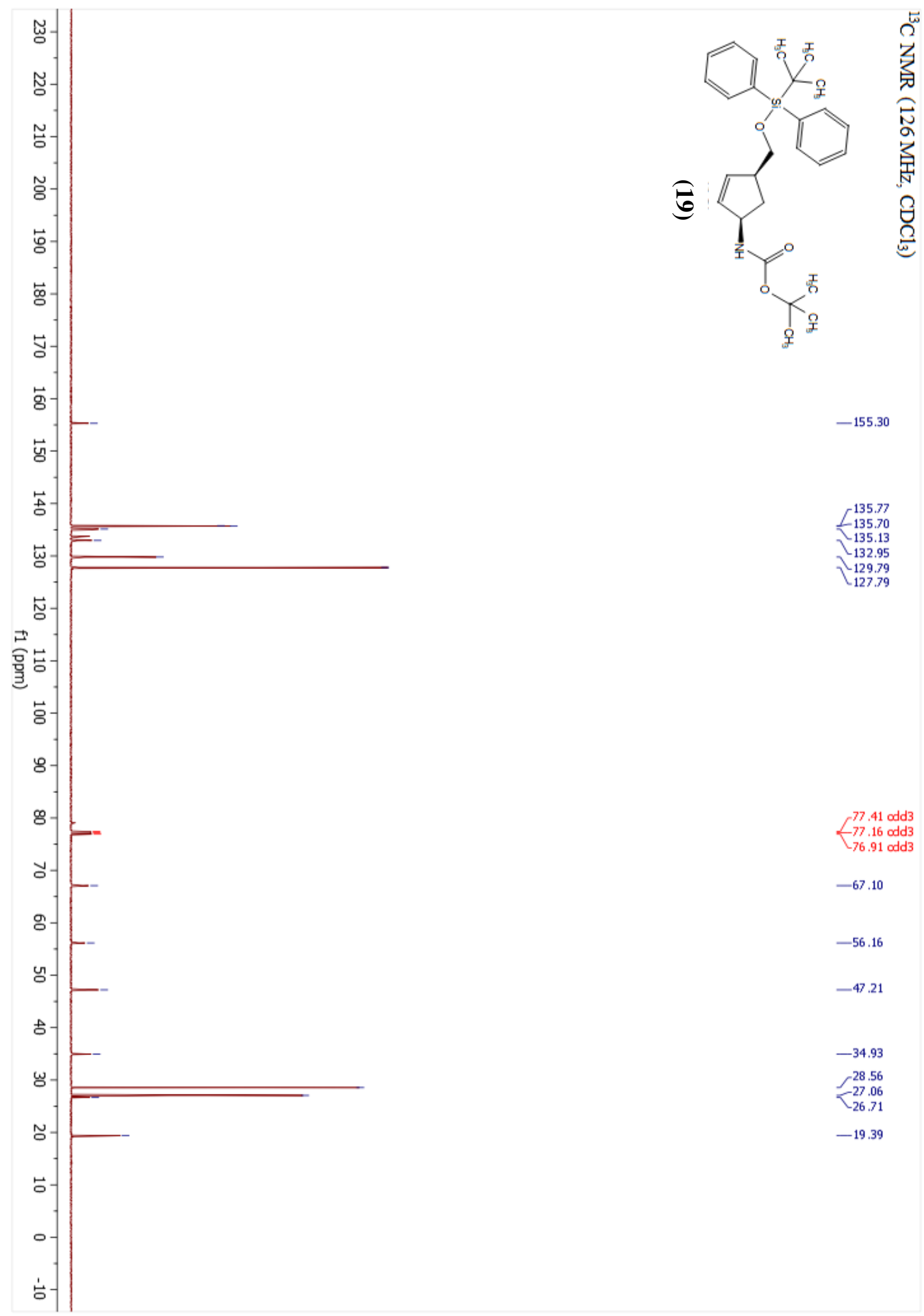


Vendola, Allais, Dechert Schmitt, Lee, Singer, and Morken Supplementary Information

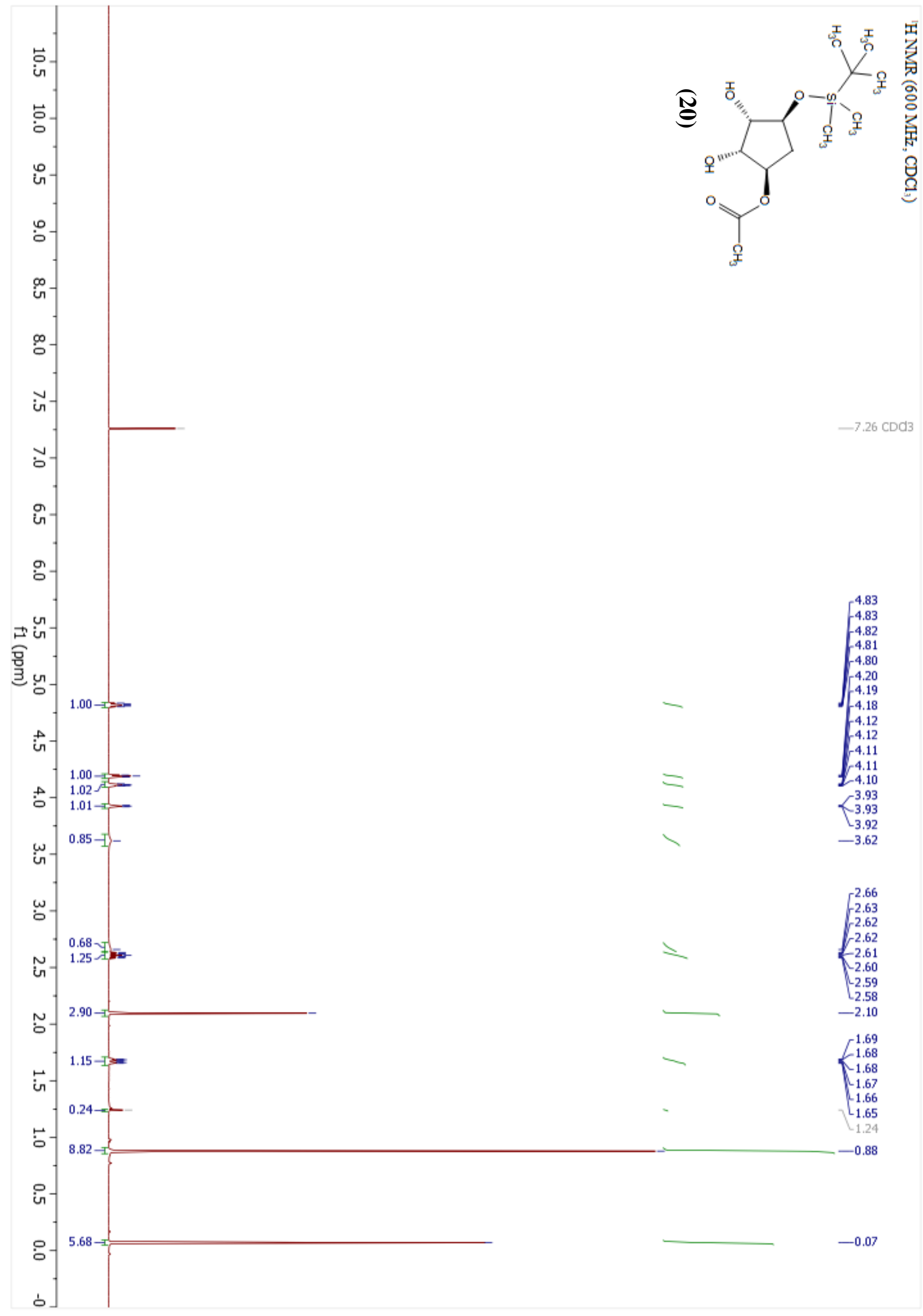


Vendola, Allais, Dechert Schmitt, Lee, Singer, and Morken Supplementary Information

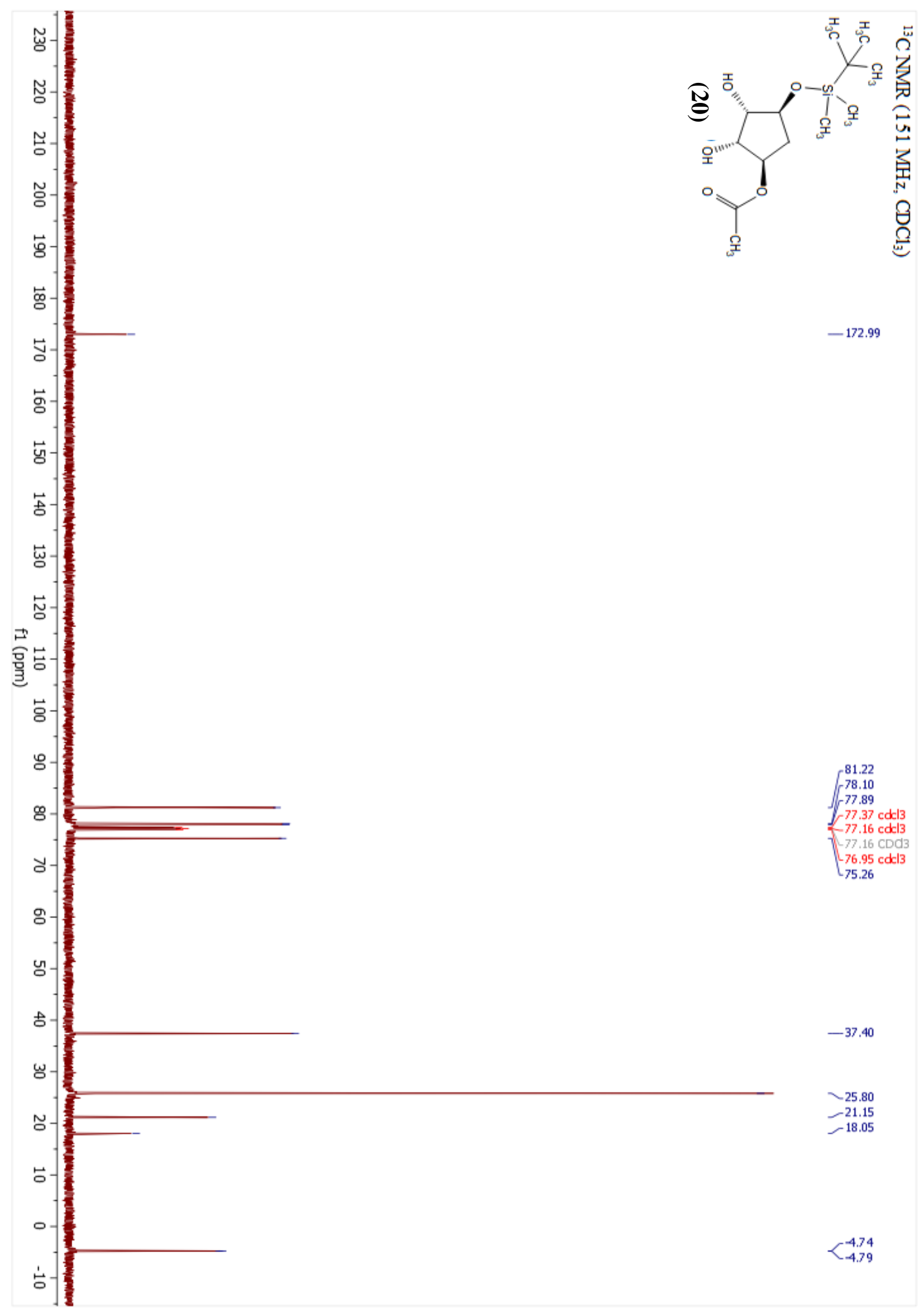


Vendola, Allais, Dechert Schmitt, Lee, Singer, and Morken Supplementary Information

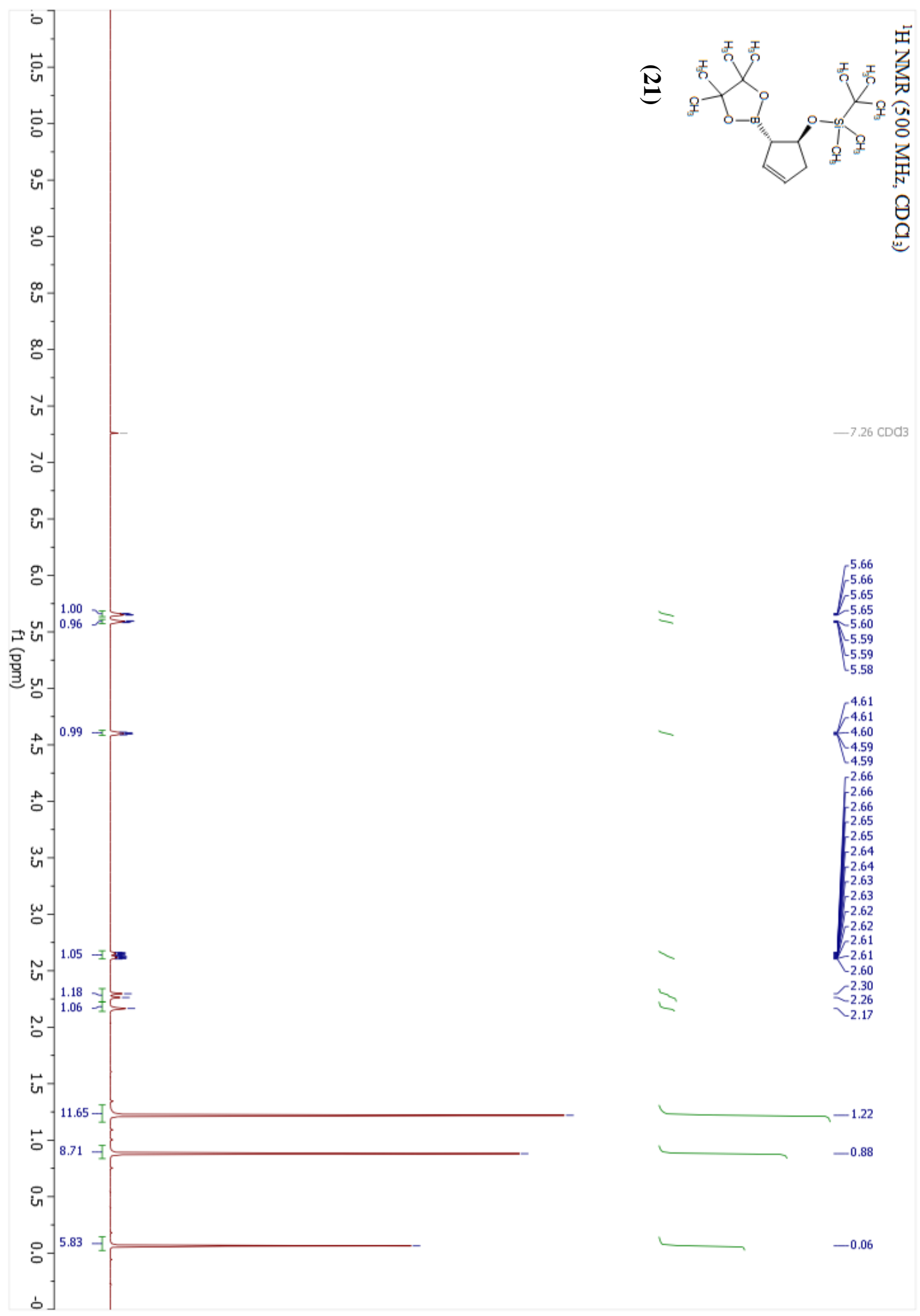


Vendola, Allais, Dechert Schmitt, Lee, Singer, and Morken Supplementary Information

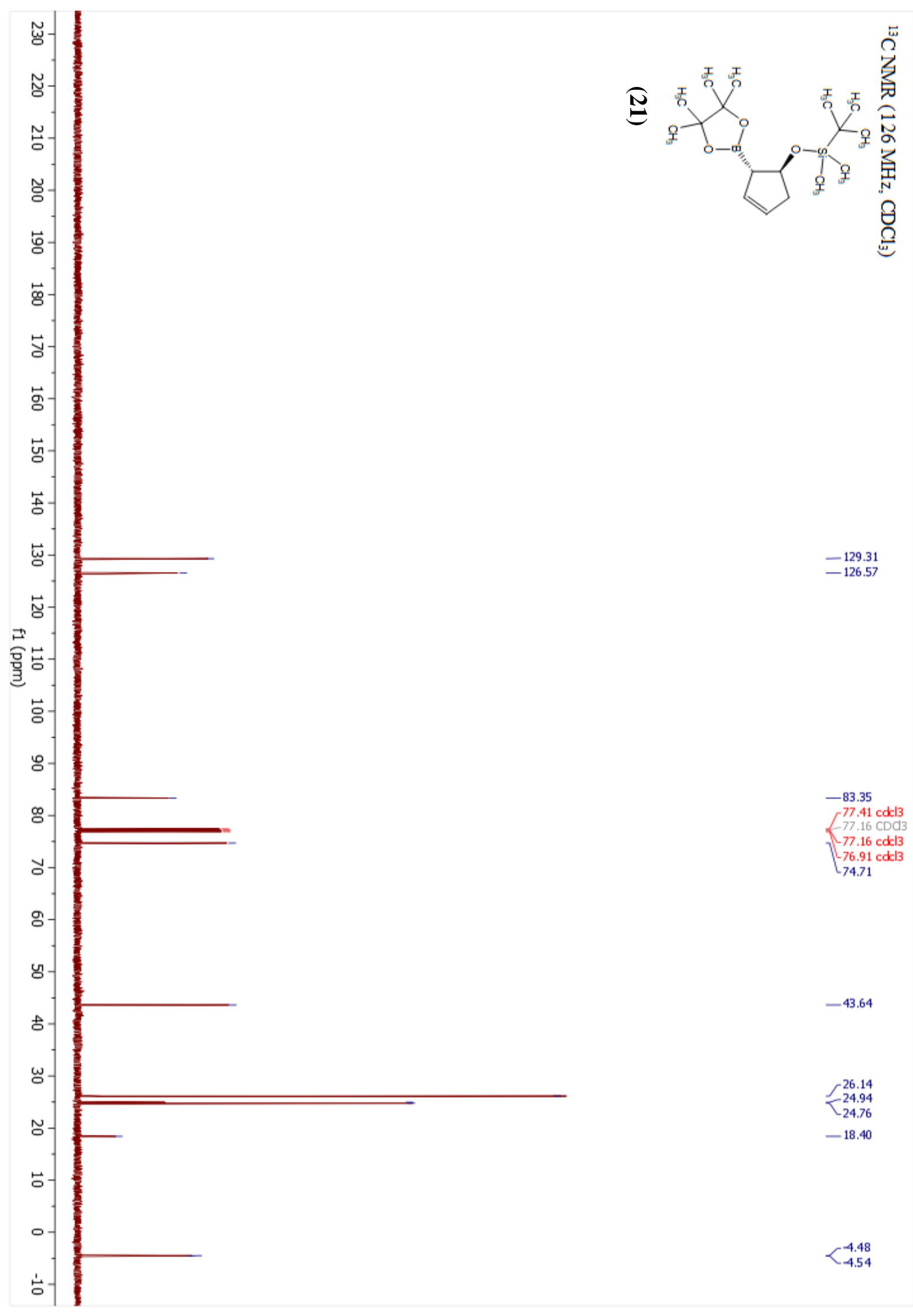


Vendola, Allais, Dechert Schmitt, Lee, Singer, and Morken Supplementary Information

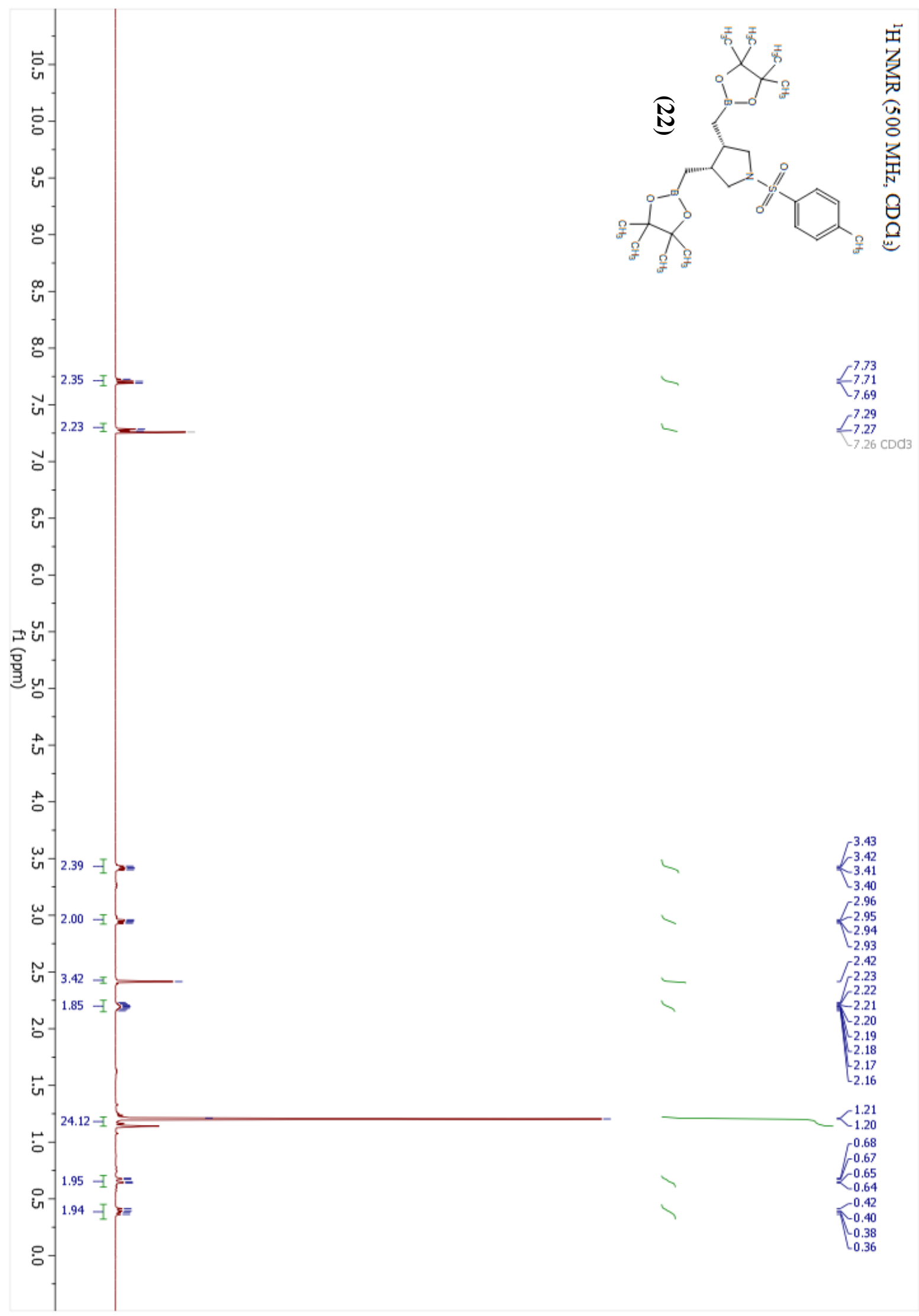


Vendola, Allais, Dechert Schmitt, Lee, Singer, and Morken Supplementary Information

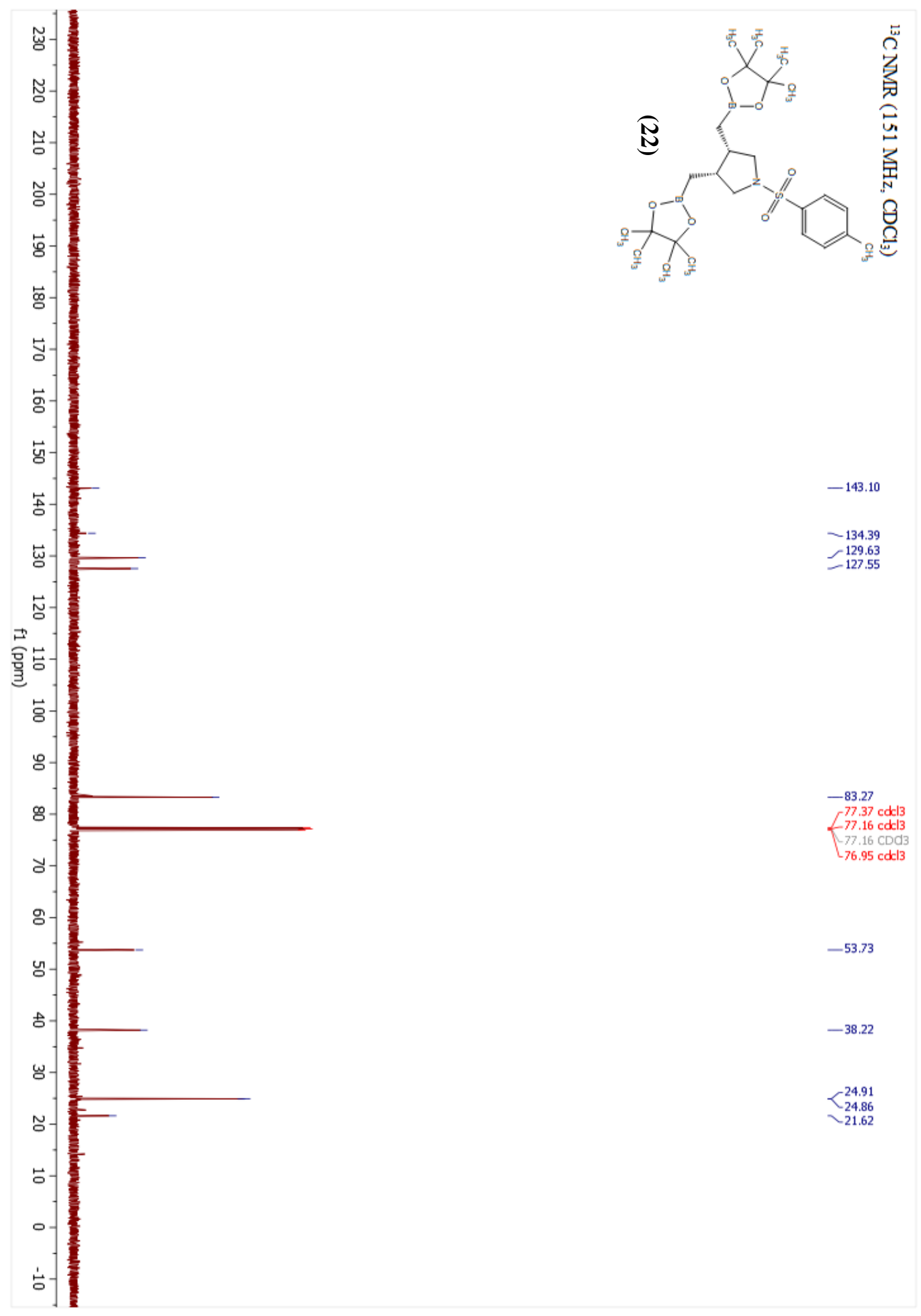


Vendola, Allais, Dechert Schmitt, Lee, Singer, and Morken Supplementary Information

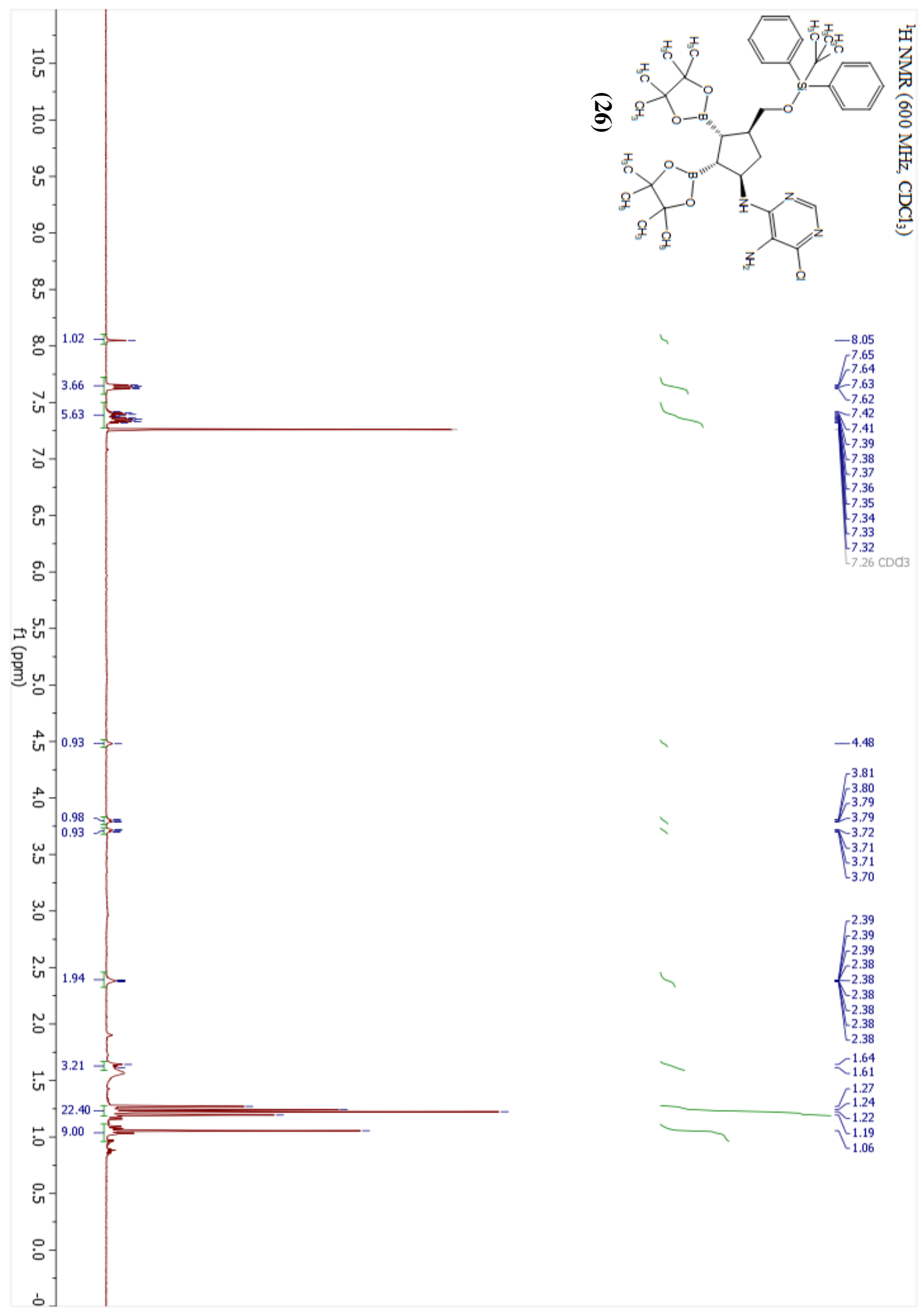


Vendola, Allais, Dechert Schmitt, Lee, Singer, and Morken Supplementary Information

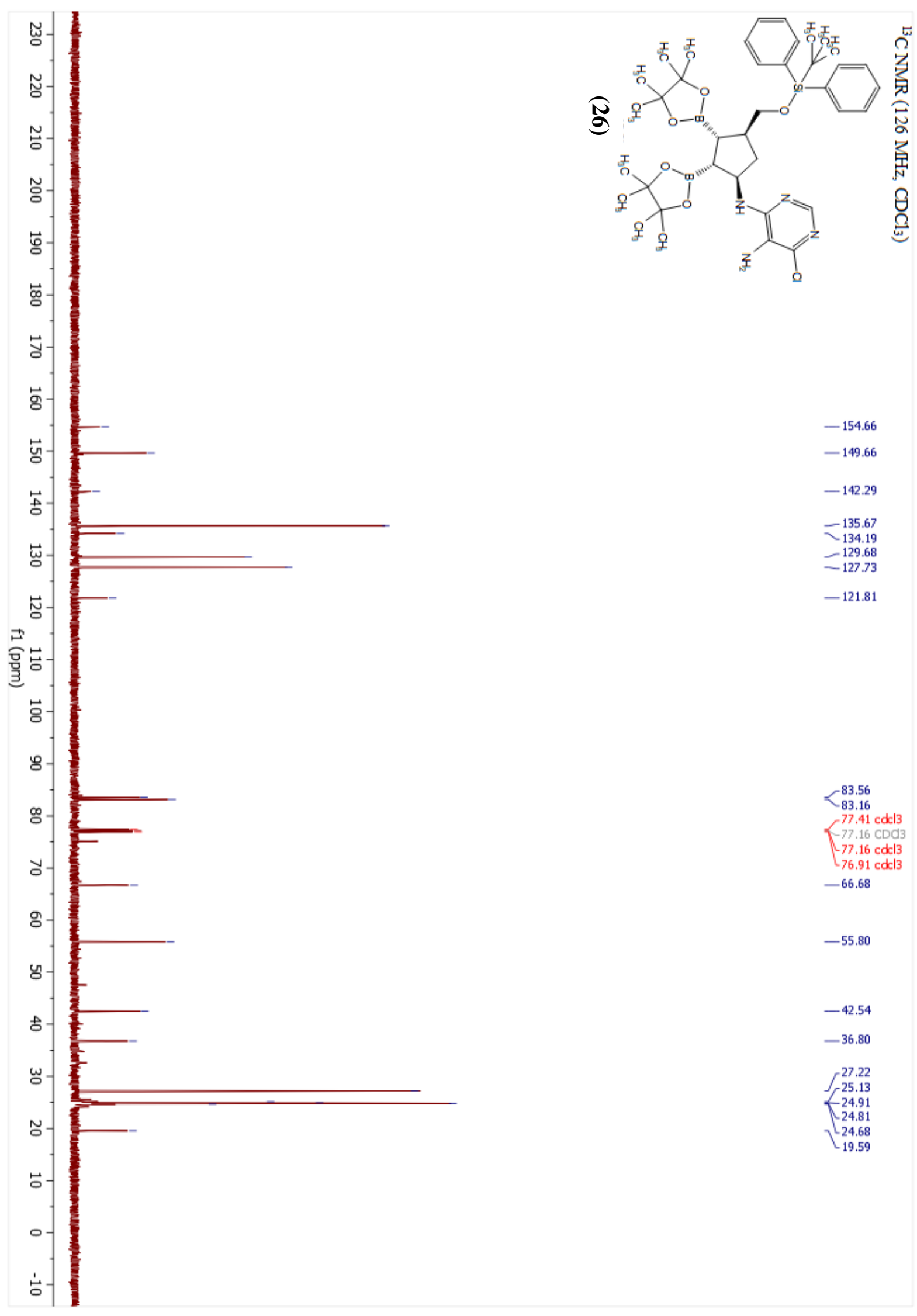


Vendola, Allais, Dechert Schmitt, Lee, Singer, and Morken Supplementary Information

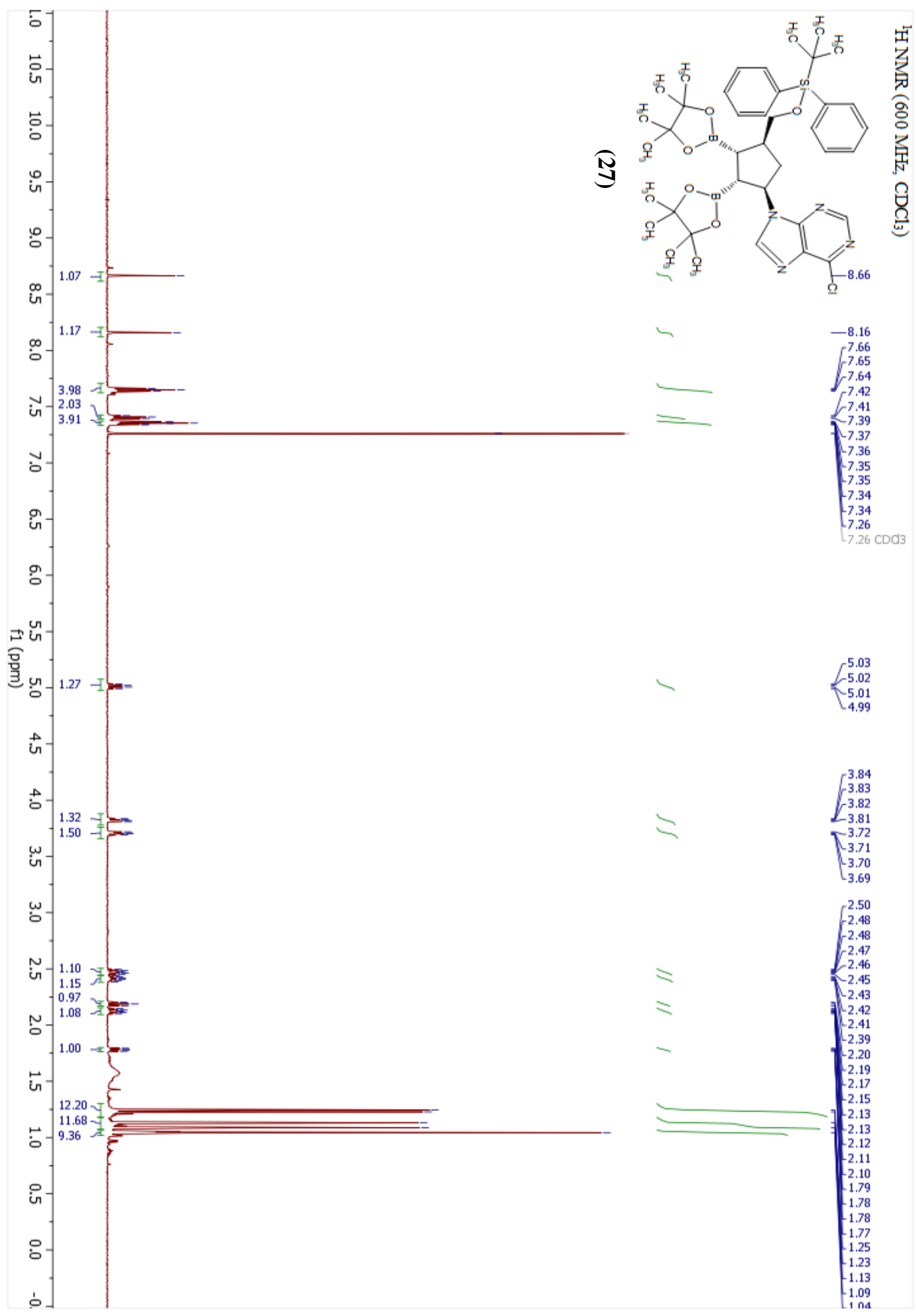


Vendola, Allais, Dechert Schmitt, Lee, Singer, and Morken Supplementary Information

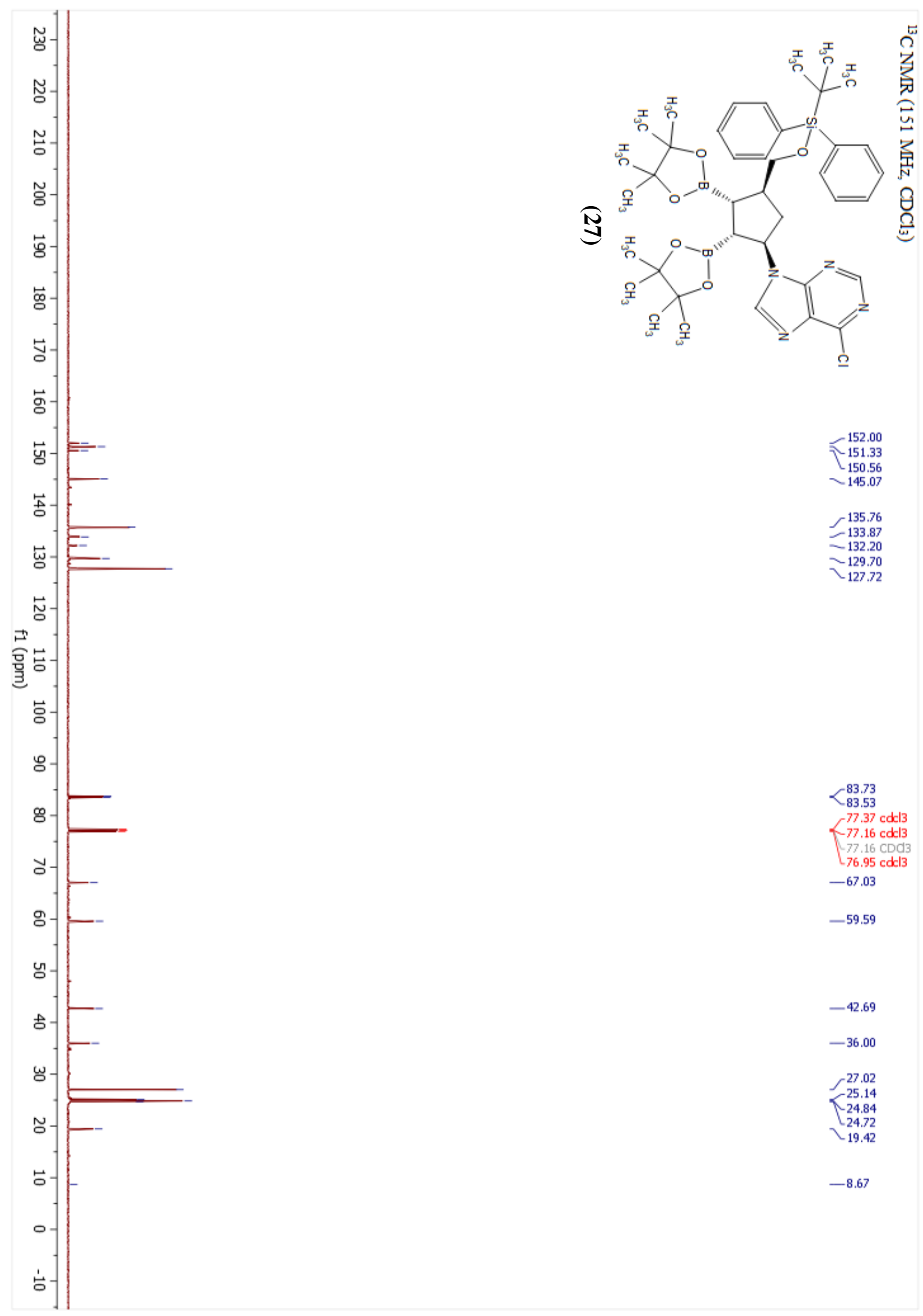


Vendola, Allais, Dechert Schmitt, Lee, Singer, and Morken Supplementary Information

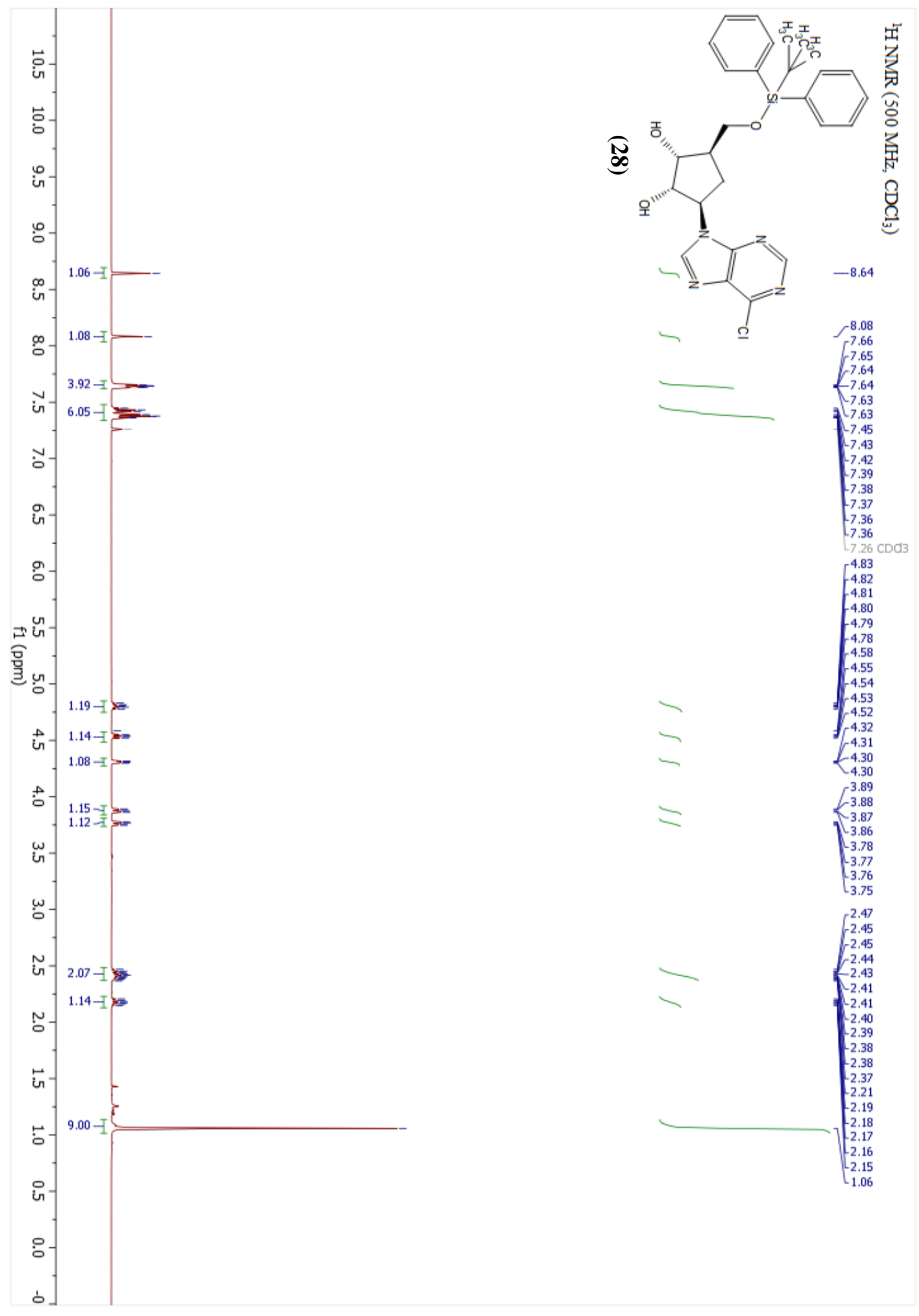


Vendola, Allais, Dechert Schmitt, Lee, Singer, and Morken Supplementary Information

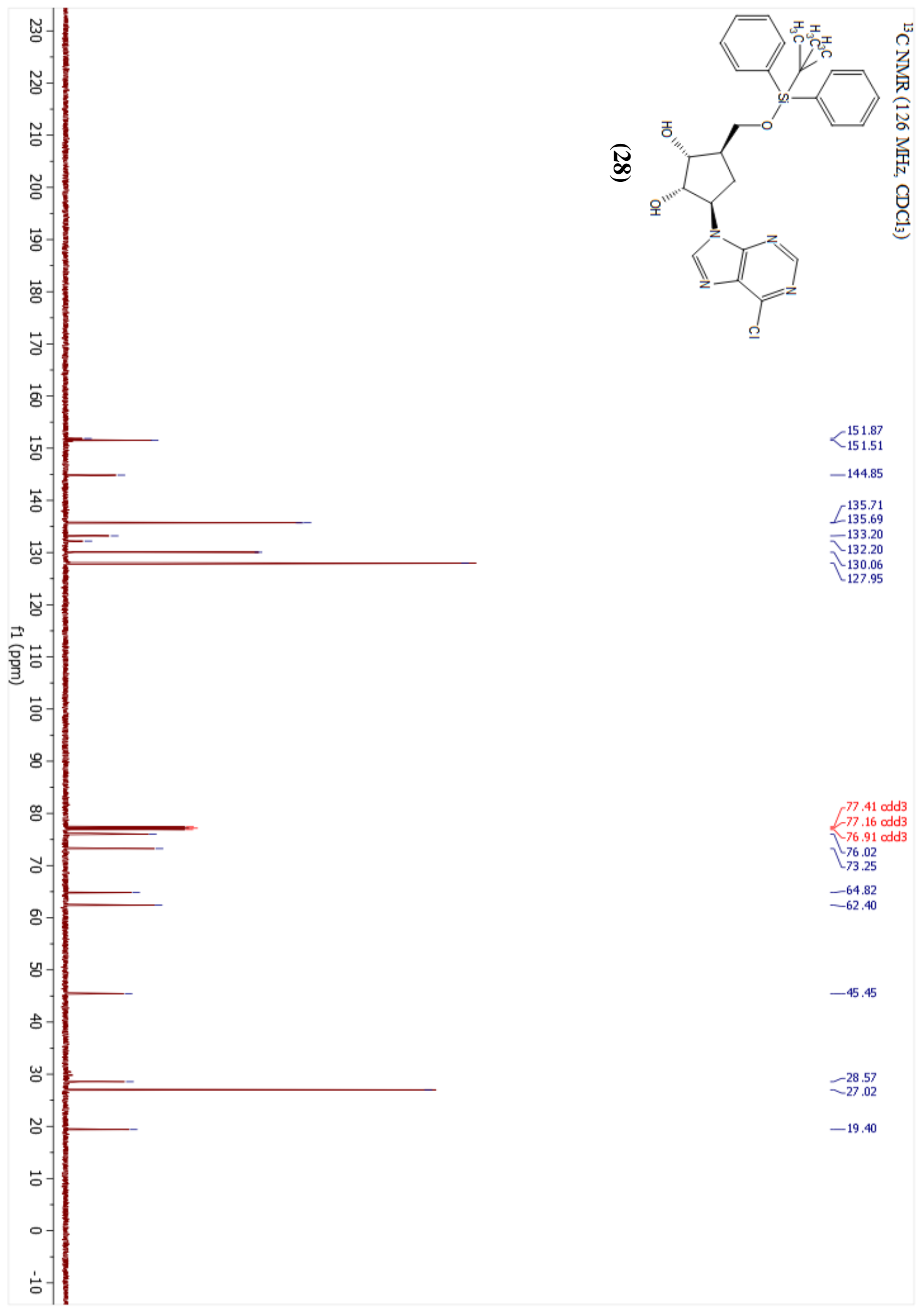


Table 1. Crystal data and structure refinement for Compound 16 (C23H39B2NO7).

Identification code

Empirical formula

Formula weight

Temperature

Wavelength

Crystal system

Space group

Unit cell dimensions

Volume

$\mathrm{Z}$

Density (calculated)

Absorption coefficient

$\mathrm{F}(000)$

Crystal size

Theta range for data collection

Index ranges

Reflections collected

Independent reflections

Completeness to theta $=66.592^{\circ}$

Absorption correction

Max. and min. transmission

Refinement method

Data / restraints / parameters

Goodness-of-fit on $\mathrm{F}^{2}$

Final R indices [I $>2 \operatorname{sigma}(\mathrm{I})]$

$\mathrm{R}$ indices (all data)

Extinction coefficient

Largest diff. peak and hole
C23H39B2NO7

C23 H39 B2 N O7

463.17

100(2) K

$1.54178 \AA$

Monoclinic

$\mathrm{P} 2{ }_{1} / \mathrm{c}$

$\mathrm{a}=14.3023(6) \AA$

$\alpha=90^{\circ}$.

$\mathrm{b}=14.5830(6) \AA$

$\beta=94.5805(15)^{\circ}$.

$\mathrm{c}=12.3451(5) \AA$

$\gamma=90^{\circ}$.

2566.60(18) $\AA^{3}$

4

$1.199 \mathrm{Mg} / \mathrm{m}^{3}$

$0.698 \mathrm{~mm}^{-1}$

1000

$0.480 \times 0.280 \times 0.160 \mathrm{~mm}^{3}$

3.100 to $66.592^{\circ}$.

$-16<=\mathrm{h}<=16,-17<=\mathrm{k}<=17,-14<=1<=14$

49831

$4477[\mathrm{R}(\mathrm{int})=0.0255]$

$98.7 \%$

Semi-empirical from equivalents

0.7528 and 0.7006

Full-matrix least-squares on $\mathrm{F}^{2}$

4477 / 6 / 319

1.037

$\mathrm{R} 1=0.0416, \mathrm{wR} 2=0.1083$

$\mathrm{R} 1=0.0439, \mathrm{wR} 2=0.1111$

$\mathrm{n} / \mathrm{a}$

0.246 and -0.202 e. $\AA^{-3}$ 
Vendola, Allais, Dechert Schmitt, Lee, Singer, and Morken Supplementary Information

Table 2. Atomic coordinates ( x 10 $)$ and equivalent isotropic displacement parameters $\left(\AA^{2} \times 10^{3}\right)$ for Compound $16(\mathrm{C} 23 \mathrm{H} 39 \mathrm{~B} 2 \mathrm{NO} 7)$. U(eq) was defined as one third of the trace of the orthogonalized $\mathrm{U}^{\mathrm{ij}}$ tensor.

\begin{tabular}{|c|c|c|c|c|}
\hline & & & $\mathrm{z}$ & $\mathrm{U}(\mathrm{eq})$ \\
\hline $\mathrm{O}(1)$ & 8901(1) & 3891(1) & $3122(1)$ & $38(1)$ \\
\hline $\mathrm{O}(2)$ & $7856(1)$ & $3547(1)$ & $4345(1)$ & $42(1)$ \\
\hline $\mathrm{O}(3)$ & $9804(1)$ & $5538(1)$ & $3466(1)$ & $39(1)$ \\
\hline $\mathrm{O}(4)$ & $7787(1)$ & $8508(1)$ & $3410(1)$ & $38(1)$ \\
\hline $\mathrm{O}(5)$ & 7601(1) & $8173(1)$ & $5174(1)$ & $40(1)$ \\
\hline $\mathrm{N}(1)$ & $8492(1)$ & 4972(1) & $4281(1)$ & $28(1)$ \\
\hline $\mathrm{B}(1)$ & 7733(1) & $7843(1)$ & $4167(1)$ & $28(1)$ \\
\hline $\mathrm{B}(2)$ & $6286(1)$ & $6420(1)$ & $4734(1)$ & $26(1)$ \\
\hline $\mathrm{C}(1)$ & $8906(1)$ & 2964(1) & $2632(1)$ & $34(1)$ \\
\hline $\mathrm{C}(2)$ & $8380(1)$ & $4070(1)$ & $3935(1)$ & $28(1)$ \\
\hline $\mathrm{C}(3)$ & $9152(1)$ & $5632(1)$ & $4022(1)$ & $29(1)$ \\
\hline $\mathrm{C}(4)$ & $8837(1)$ & $6489(1)$ & $4582(1)$ & $29(1)$ \\
\hline$C(5)$ & $8461(1)$ & $6090(1)$ & $5609(1)$ & $31(1)$ \\
\hline$C(6)$ & $7816(1)$ & $5418(1)$ & $4970(1)$ & $27(1)$ \\
\hline $\mathrm{C}(7)$ & 7914(1) & $6806(1)$ & $3903(1)$ & $26(1)$ \\
\hline $\mathrm{C}(8)$ & $7189(1)$ & $6056(1)$ & $4226(1)$ & $25(1)$ \\
\hline $\mathrm{C}(9)$ & $9520(2)$ & $3100(1)$ & $1708(2)$ & $76(1)$ \\
\hline$C(10)$ & $9350(1)$ & $2296(1)$ & $3435(1)$ & $46(1)$ \\
\hline $\mathrm{C}(11)$ & 7927(1) & $2675(2)$ & $2213(2)$ & $65(1)$ \\
\hline $\mathrm{C}(12)$ & $7564(1)$ & 9379(1) & $3912(1)$ & $40(1)$ \\
\hline$C(13)$ & $7759(1)$ & 9163(1) & $5139(1)$ & $42(1)$ \\
\hline$C(14)$ & $8165(2)$ & 10118(1) & $3472(2)$ & $73(1)$ \\
\hline$C(15)$ & $6535(1)$ & $9568(1)$ & $3583(2)$ & $58(1)$ \\
\hline$C(16)$ & $8780(2)$ & $9308(2)$ & $5554(2)$ & $73(1)$ \\
\hline $\mathrm{C}(17)$ & $7113(2)$ & $9630(1)$ & $5875(2)$ & $62(1)$ \\
\hline $\mathrm{O}(6)$ & $5712(1)$ & $7065(1)$ & $4239(1)$ & $30(1)$ \\
\hline $\mathrm{O}(7)$ & $5965(1)$ & $6078(1)$ & $5666(1)$ & $29(1)$ \\
\hline $\mathrm{C}(18)$ & $4836(1)$ & $7045(1)$ & $4780(1)$ & $31(1)$ \\
\hline$C(19)$ & $5176(1)$ & $6663(1)$ & $5918(1)$ & $32(1)$ \\
\hline$C(20)$ & $4432(1)$ & $8013(1)$ & $4782(1)$ & $42(1)$ \\
\hline $\mathrm{C}(21)$ & $4167(1)$ & 6401(1) & $4133(1)$ & $40(1)$ \\
\hline
\end{tabular}


Vendola, Allais, Dechert Schmitt, Lee, Singer, and Morken Supplementary Information

\begin{tabular}{lllll}
$\mathrm{C}(22)$ & $5586(1)$ & $7404(1)$ & $6684(1)$ & $51(1)$ \\
$\mathrm{C}(23)$ & $4464(1)$ & $6077(1)$ & $6440(1)$ & $44(1)$ \\
$\mathrm{O}(6 \mathrm{X})$ & $6024(13)$ & $7433(13)$ & $4686(17)$ & $12(6)$ \\
$\mathrm{O}(7 X)$ & $5729(16)$ & $5948(14)$ & $5180(30)$ & $21(6)$ \\
$\mathrm{C}(18 X)$ & $5235(17)$ & $7493(15)$ & $5380(20)$ & $19(8)$ \\
$\mathrm{C}(19 X)$ & $4867(15)$ & $6502(15)$ & $5270(30)$ & $14(7)$ \\
$\mathrm{C}(20 X)$ & $4432(1)$ & $8013(1)$ & $4782(1)$ & $40(20)$ \\
$\mathrm{C}(21 X)$ & $4167(1)$ & $6401(1)$ & $4133(1)$ & $29(15)$ \\
$\mathrm{C}(22 X)$ & $5586(1)$ & $7404(1)$ & $6684(1)$ & $55(14)$ \\
$\mathrm{C}(23 X)$ & $4464(1)$ & $6077(1)$ & $6440(1)$ & $34(14)$ \\
& & & & \\
\hline
\end{tabular}


Vendola, Allais, Dechert Schmitt, Lee, Singer, and Morken Supplementary Information

Table 3. Bond lengths $[\AA]$ and angles $\left[{ }^{\circ}\right]$ for Compound 16 (C23H39B2NO7).

\begin{tabular}{|c|c|}
\hline $\mathrm{O}(1)-\mathrm{C}(2)$ & $1.3237(16)$ \\
\hline $\mathrm{O}(1)-\mathrm{C}(1)$ & $1.4813(16)$ \\
\hline $\mathrm{O}(2)-\mathrm{C}(2)$ & $1.2079(17)$ \\
\hline $\mathrm{O}(3)-\mathrm{C}(3)$ & $1.2078(16)$ \\
\hline $\mathrm{O}(4)-\mathrm{B}(1)$ & $1.3536(18)$ \\
\hline $\mathrm{O}(4)-\mathrm{C}(12)$ & $1.4594(17)$ \\
\hline $\mathrm{O}(5)-\mathrm{B}(1)$ & $1.3604(19)$ \\
\hline $\mathrm{O}(5)-\mathrm{C}(13)$ & $1.4626(18)$ \\
\hline $\mathrm{N}(1)-\mathrm{C}(2)$ & $1.3875(17)$ \\
\hline $\mathrm{N}(1)-\mathrm{C}(3)$ & $1.4037(17)$ \\
\hline $\mathrm{N}(1)-\mathrm{C}(6)$ & $1.4884(16)$ \\
\hline $\mathrm{B}(1)-\mathrm{C}(7)$ & $1.5740(19)$ \\
\hline $\mathrm{B}(2)-\mathrm{O}(6)$ & $1.3614(18)$ \\
\hline $\mathrm{B}(2)-\mathrm{O}(7)$ & $1.3663(18)$ \\
\hline $\mathrm{B}(2)-\mathrm{C}(8)$ & $1.5727(18)$ \\
\hline $\mathrm{C}(1)-\mathrm{C}(10)$ & $1.495(2)$ \\
\hline $\mathrm{C}(1)-\mathrm{C}(9)$ & $1.508(2)$ \\
\hline $\mathrm{C}(1)-\mathrm{C}(11)$ & $1.512(2)$ \\
\hline $\mathrm{C}(3)-\mathrm{C}(4)$ & $1.5144(18)$ \\
\hline $\mathrm{C}(4)-\mathrm{C}(5)$ & $1.5309(19)$ \\
\hline $\mathrm{C}(4)-\mathrm{C}(7)$ & $1.5756(18)$ \\
\hline $\mathrm{C}(4)-\mathrm{H}(4)$ & 1.0000 \\
\hline $\mathrm{C}(5)-\mathrm{C}(6)$ & $1.5220(19)$ \\
\hline $\mathrm{C}(5)-\mathrm{H}(5 \mathrm{~A})$ & 0.9900 \\
\hline $\mathrm{C}(5)-\mathrm{H}(5 \mathrm{~B})$ & 0.9900 \\
\hline $\mathrm{C}(6)-\mathrm{C}(8)$ & $1.5439(18)$ \\
\hline $\mathrm{C}(6)-\mathrm{H}(6)$ & 1.0000 \\
\hline$C(7)-C(8)$ & $1.5795(17)$ \\
\hline $\mathrm{C}(7)-\mathrm{H}(7)$ & 1.0000 \\
\hline $\mathrm{C}(8)-\mathrm{H}(8)$ & 1.0000 \\
\hline $\mathrm{C}(9)-\mathrm{H}(9 \mathrm{~A})$ & 0.9800 \\
\hline $\mathrm{C}(9)-\mathrm{H}(9 \mathrm{~B})$ & 0.9800 \\
\hline $\mathrm{C}(9)-\mathrm{H}(9 \mathrm{C})$ & 0.9800 \\
\hline $\mathrm{C}(10)-\mathrm{H}(10 \mathrm{~A})$ & 0.9800 \\
\hline
\end{tabular}


Vendola, Allais, Dechert Schmitt, Lee, Singer, and Morken Supplementary Information

\begin{tabular}{|c|c|}
\hline $\mathrm{C}(10)-\mathrm{H}(10 \mathrm{~B})$ & 0.9800 \\
\hline $\mathrm{C}(10)-\mathrm{H}(10 \mathrm{C})$ & 0.9800 \\
\hline $\mathrm{C}(11)-\mathrm{H}(11 \mathrm{~A})$ & 0.9800 \\
\hline $\mathrm{C}(11)-\mathrm{H}(11 \mathrm{~B})$ & 0.9800 \\
\hline $\mathrm{C}(11)-\mathrm{H}(11 \mathrm{C})$ & 0.9800 \\
\hline$C(12)-C(14)$ & $1.506(2)$ \\
\hline$C(12)-C(15)$ & $1.521(2)$ \\
\hline$C(12)-C(13)$ & $1.551(2)$ \\
\hline$C(13)-C(17)$ & $1.509(2)$ \\
\hline$C(13)-C(16)$ & $1.522(3)$ \\
\hline $\mathrm{C}(14)-\mathrm{H}(14 \mathrm{~A})$ & 0.9800 \\
\hline $\mathrm{C}(14)-\mathrm{H}(14 \mathrm{~B})$ & 0.9800 \\
\hline $\mathrm{C}(14)-\mathrm{H}(14 \mathrm{C})$ & 0.9800 \\
\hline $\mathrm{C}(15)-\mathrm{H}(15 \mathrm{~A})$ & 0.9800 \\
\hline $\mathrm{C}(15)-\mathrm{H}(15 \mathrm{~B})$ & 0.9800 \\
\hline $\mathrm{C}(15)-\mathrm{H}(15 \mathrm{C})$ & 0.9800 \\
\hline $\mathrm{C}(16)-\mathrm{H}(16 \mathrm{~A})$ & 0.9800 \\
\hline $\mathrm{C}(16)-\mathrm{H}(16 \mathrm{~B})$ & 0.9800 \\
\hline $\mathrm{C}(16)-\mathrm{H}(16 \mathrm{C})$ & 0.9800 \\
\hline $\mathrm{C}(17)-\mathrm{H}(17 \mathrm{~A})$ & 0.9800 \\
\hline $\mathrm{C}(17)-\mathrm{H}(17 \mathrm{~B})$ & 0.9800 \\
\hline $\mathrm{C}(17)-\mathrm{H}(17 \mathrm{C})$ & 0.9800 \\
\hline $\mathrm{O}(6)-\mathrm{C}(18)$ & $1.4654(16)$ \\
\hline $\mathrm{O}(7)-\mathrm{C}(19)$ & $1.4675(16)$ \\
\hline $\mathrm{C}(18)-\mathrm{C}(21)$ & $1.521(2)$ \\
\hline $\mathrm{C}(18)-\mathrm{C}(20)$ & $1.526(2)$ \\
\hline $\mathrm{C}(18)-\mathrm{C}(19)$ & $1.553(2)$ \\
\hline$C(19)-C(23)$ & $1.512(2)$ \\
\hline$C(19)-C(22)$ & $1.522(2)$ \\
\hline $\mathrm{C}(20)-\mathrm{H}(20 \mathrm{~A})$ & 0.9800 \\
\hline $\mathrm{C}(20)-\mathrm{H}(20 \mathrm{~B})$ & 0.9800 \\
\hline $\mathrm{C}(20)-\mathrm{H}(20 \mathrm{C})$ & 0.9800 \\
\hline $\mathrm{C}(21)-\mathrm{H}(21 \mathrm{~A})$ & 0.9800 \\
\hline $\mathrm{C}(21)-\mathrm{H}(21 \mathrm{~B})$ & 0.9800 \\
\hline $\mathrm{C}(21)-\mathrm{H}(21 \mathrm{C})$ & 0.9800 \\
\hline $\mathrm{C}(22)-\mathrm{H}(22 \mathrm{~A})$ & 0.9800 \\
\hline
\end{tabular}


Vendola, Allais, Dechert Schmitt, Lee, Singer, and Morken Supplementary Information

\begin{tabular}{|c|c|}
\hline $\mathrm{C}(22)-\mathrm{H}(22 \mathrm{~B})$ & 0.9800 \\
\hline $\mathrm{C}(22)-\mathrm{H}(22 \mathrm{C})$ & 0.9800 \\
\hline $\mathrm{C}(23)-\mathrm{H}(23 \mathrm{~A})$ & 0.9800 \\
\hline $\mathrm{C}(23)-\mathrm{H}(23 \mathrm{~B})$ & 0.9800 \\
\hline $\mathrm{C}(23)-\mathrm{H}(23 \mathrm{C})$ & 0.9800 \\
\hline $\mathrm{C}(2)-\mathrm{O}(1)-\mathrm{C}(1)$ & $120.70(11)$ \\
\hline $\mathrm{B}(1)-\mathrm{O}(4)-\mathrm{C}(12)$ & $107.68(11)$ \\
\hline $\mathrm{B}(1)-\mathrm{O}(5)-\mathrm{C}(13)$ & $106.77(11)$ \\
\hline $\mathrm{C}(2)-\mathrm{N}(1)-\mathrm{C}(3)$ & $130.09(11)$ \\
\hline $\mathrm{C}(2)-\mathrm{N}(1)-\mathrm{C}(6)$ & $121.69(10)$ \\
\hline $\mathrm{C}(3)-\mathrm{N}(1)-\mathrm{C}(6)$ & $108.05(10)$ \\
\hline $\mathrm{O}(4)-\mathrm{B}(1)-\mathrm{O}(5)$ & $113.44(12)$ \\
\hline $\mathrm{O}(4)-\mathrm{B}(1)-\mathrm{C}(7)$ & $121.79(12)$ \\
\hline $\mathrm{O}(5)-\mathrm{B}(1)-\mathrm{C}(7)$ & $124.48(12)$ \\
\hline $\mathrm{O}(6)-\mathrm{B}(2)-\mathrm{O}(7)$ & $113.57(12)$ \\
\hline $\mathrm{O}(6)-\mathrm{B}(2)-\mathrm{C}(8)$ & $122.62(12)$ \\
\hline $\mathrm{O}(7)-\mathrm{B}(2)-\mathrm{C}(8)$ & $123.65(12)$ \\
\hline $\mathrm{O}(1)-\mathrm{C}(1)-\mathrm{C}(10)$ & $109.85(12)$ \\
\hline $\mathrm{O}(1)-\mathrm{C}(1)-\mathrm{C}(9)$ & $102.15(12)$ \\
\hline $\mathrm{C}(10)-\mathrm{C}(1)-\mathrm{C}(9)$ & $110.14(15)$ \\
\hline $\mathrm{O}(1)-\mathrm{C}(1)-\mathrm{C}(11)$ & $111.10(12)$ \\
\hline $\mathrm{C}(10)-\mathrm{C}(1)-\mathrm{C}(11)$ & $112.27(15)$ \\
\hline $\mathrm{C}(9)-\mathrm{C}(1)-\mathrm{C}(11)$ & $110.89(17)$ \\
\hline $\mathrm{O}(2)-\mathrm{C}(2)-\mathrm{O}(1)$ & $126.79(13)$ \\
\hline $\mathrm{O}(2)-\mathrm{C}(2)-\mathrm{N}(1)$ & $122.01(12)$ \\
\hline $\mathrm{O}(1)-\mathrm{C}(2)-\mathrm{N}(1)$ & $111.20(11)$ \\
\hline $\mathrm{O}(3)-\mathrm{C}(3)-\mathrm{N}(1)$ & $127.93(12)$ \\
\hline $\mathrm{O}(3)-\mathrm{C}(3)-\mathrm{C}(4)$ & $128.65(12)$ \\
\hline $\mathrm{N}(1)-\mathrm{C}(3)-\mathrm{C}(4)$ & $103.41(10)$ \\
\hline$C(3)-C(4)-C(5)$ & $101.63(10)$ \\
\hline $\mathrm{C}(3)-\mathrm{C}(4)-\mathrm{C}(7)$ & $105.42(11)$ \\
\hline$C(5)-C(4)-C(7)$ & $102.55(10)$ \\
\hline $\mathrm{C}(3)-\mathrm{C}(4)-\mathrm{H}(4)$ & 115.2 \\
\hline $\mathrm{C}(5)-\mathrm{C}(4)-\mathrm{H}(4)$ & 115.2 \\
\hline $\mathrm{C}(7)-\mathrm{C}(4)-\mathrm{H}(4)$ & 115.2 \\
\hline
\end{tabular}


Vendola, Allais, Dechert Schmitt, Lee, Singer, and Morken Supplementary Information

\begin{tabular}{|c|c|}
\hline$C(6)-C(5)-C(4)$ & $93.13(10)$ \\
\hline $\mathrm{C}(6)-\mathrm{C}(5)-\mathrm{H}(5 \mathrm{~A})$ & 113.1 \\
\hline $\mathrm{C}(4)-\mathrm{C}(5)-\mathrm{H}(5 \mathrm{~A})$ & 113.1 \\
\hline $\mathrm{C}(6)-\mathrm{C}(5)-\mathrm{H}(5 \mathrm{~B})$ & 113.1 \\
\hline $\mathrm{C}(4)-\mathrm{C}(5)-\mathrm{H}(5 \mathrm{~B})$ & 113.1 \\
\hline $\mathrm{H}(5 \mathrm{~A})-\mathrm{C}(5)-\mathrm{H}(5 \mathrm{~B})$ & 110.5 \\
\hline $\mathrm{N}(1)-\mathrm{C}(6)-\mathrm{C}(5)$ & $100.55(10)$ \\
\hline $\mathrm{N}(1)-\mathrm{C}(6)-\mathrm{C}(8)$ & $107.24(10)$ \\
\hline$C(5)-C(6)-C(8)$ & $102.68(10)$ \\
\hline $\mathrm{N}(1)-\mathrm{C}(6)-\mathrm{H}(6)$ & 114.9 \\
\hline $\mathrm{C}(5)-\mathrm{C}(6)-\mathrm{H}(6)$ & 114.9 \\
\hline $\mathrm{C}(8)-\mathrm{C}(6)-\mathrm{H}(6)$ & 114.9 \\
\hline $\mathrm{B}(1)-\mathrm{C}(7)-\mathrm{C}(4)$ & $108.43(11)$ \\
\hline $\mathrm{B}(1)-\mathrm{C}(7)-\mathrm{C}(8)$ & $119.42(11)$ \\
\hline$C(4)-C(7)-C(8)$ & $101.65(10)$ \\
\hline $\mathrm{B}(1)-\mathrm{C}(7)-\mathrm{H}(7)$ & 108.9 \\
\hline $\mathrm{C}(4)-\mathrm{C}(7)-\mathrm{H}(7)$ & 108.9 \\
\hline $\mathrm{C}(8)-\mathrm{C}(7)-\mathrm{H}(7)$ & 108.9 \\
\hline $\mathrm{C}(6)-\mathrm{C}(8)-\mathrm{B}(2)$ & $115.03(11)$ \\
\hline$C(6)-C(8)-C(7)$ & $101.86(10)$ \\
\hline $\mathrm{B}(2)-\mathrm{C}(8)-\mathrm{C}(7)$ & $116.34(10)$ \\
\hline $\mathrm{C}(6)-\mathrm{C}(8)-\mathrm{H}(8)$ & 107.7 \\
\hline $\mathrm{B}(2)-\mathrm{C}(8)-\mathrm{H}(8)$ & 107.7 \\
\hline $\mathrm{C}(7)-\mathrm{C}(8)-\mathrm{H}(8)$ & 107.7 \\
\hline $\mathrm{C}(1)-\mathrm{C}(9)-\mathrm{H}(9 \mathrm{~A})$ & 109.5 \\
\hline $\mathrm{C}(1)-\mathrm{C}(9)-\mathrm{H}(9 \mathrm{~B})$ & 109.5 \\
\hline $\mathrm{H}(9 \mathrm{~A})-\mathrm{C}(9)-\mathrm{H}(9 \mathrm{~B})$ & 109.5 \\
\hline $\mathrm{C}(1)-\mathrm{C}(9)-\mathrm{H}(9 \mathrm{C})$ & 109.5 \\
\hline $\mathrm{H}(9 \mathrm{~A})-\mathrm{C}(9)-\mathrm{H}(9 \mathrm{C})$ & 109.5 \\
\hline $\mathrm{H}(9 \mathrm{~B})-\mathrm{C}(9)-\mathrm{H}(9 \mathrm{C})$ & 109.5 \\
\hline $\mathrm{C}(1)-\mathrm{C}(10)-\mathrm{H}(10 \mathrm{~A})$ & 109.5 \\
\hline $\mathrm{C}(1)-\mathrm{C}(10)-\mathrm{H}(10 \mathrm{~B})$ & 109.5 \\
\hline$H(10 A)-C(10)-H(10 B)$ & 109.5 \\
\hline $\mathrm{C}(1)-\mathrm{C}(10)-\mathrm{H}(10 \mathrm{C})$ & 109.5 \\
\hline$H(10 A)-C(10)-H(10 C)$ & 109.5 \\
\hline $\mathrm{H}(10 \mathrm{~B})-\mathrm{C}(10)-\mathrm{H}(10 \mathrm{C})$ & 109.5 \\
\hline
\end{tabular}


Vendola, Allais, Dechert Schmitt, Lee, Singer, and Morken Supplementary Information

\begin{tabular}{|c|c|}
\hline $\mathrm{C}(1)-\mathrm{C}(11)-\mathrm{H}(11 \mathrm{~A})$ & 109.5 \\
\hline $\mathrm{C}(1)-\mathrm{C}(11)-\mathrm{H}(11 \mathrm{~B})$ & 109.5 \\
\hline $\mathrm{H}(11 \mathrm{~A})-\mathrm{C}(11)-\mathrm{H}(11 \mathrm{~B})$ & 109.5 \\
\hline $\mathrm{C}(1)-\mathrm{C}(11)-\mathrm{H}(11 \mathrm{C})$ & 109.5 \\
\hline $\mathrm{H}(11 \mathrm{~A})-\mathrm{C}(11)-\mathrm{H}(11 \mathrm{C})$ & 109.5 \\
\hline $\mathrm{H}(11 \mathrm{~B})-\mathrm{C}(11)-\mathrm{H}(11 \mathrm{C})$ & 109.5 \\
\hline $\mathrm{O}(4)-\mathrm{C}(12)-\mathrm{C}(14)$ & $108.60(14)$ \\
\hline $\mathrm{O}(4)-\mathrm{C}(12)-\mathrm{C}(15)$ & $106.46(13)$ \\
\hline$C(14)-C(12)-C(15)$ & $110.06(16)$ \\
\hline $\mathrm{O}(4)-\mathrm{C}(12)-\mathrm{C}(13)$ & 102.11(11) \\
\hline $\mathrm{C}(14)-\mathrm{C}(12)-\mathrm{C}(13)$ & $115.74(16)$ \\
\hline$C(15)-C(12)-C(13)$ & $113.08(15)$ \\
\hline $\mathrm{O}(5)-\mathrm{C}(13)-\mathrm{C}(17)$ & $108.90(14)$ \\
\hline $\mathrm{O}(5)-\mathrm{C}(13)-\mathrm{C}(16)$ & $105.88(14)$ \\
\hline$C(17)-C(13)-C(16)$ & $110.59(16)$ \\
\hline $\mathrm{O}(5)-\mathrm{C}(13)-\mathrm{C}(12)$ & $102.33(11)$ \\
\hline $\mathrm{C}(17)-\mathrm{C}(13)-\mathrm{C}(12)$ & $115.17(14)$ \\
\hline$C(16)-C(13)-C(12)$ & $113.16(17)$ \\
\hline $\mathrm{C}(12)-\mathrm{C}(14)-\mathrm{H}(14 \mathrm{~A})$ & 109.5 \\
\hline $\mathrm{C}(12)-\mathrm{C}(14)-\mathrm{H}(14 \mathrm{~B})$ & 109.5 \\
\hline $\mathrm{H}(14 \mathrm{~A})-\mathrm{C}(14)-\mathrm{H}(14 \mathrm{~B})$ & 109.5 \\
\hline $\mathrm{C}(12)-\mathrm{C}(14)-\mathrm{H}(14 \mathrm{C})$ & 109.5 \\
\hline $\mathrm{H}(14 \mathrm{~A})-\mathrm{C}(14)-\mathrm{H}(14 \mathrm{C})$ & 109.5 \\
\hline $\mathrm{H}(14 \mathrm{~B})-\mathrm{C}(14)-\mathrm{H}(14 \mathrm{C})$ & 109.5 \\
\hline $\mathrm{C}(12)-\mathrm{C}(15)-\mathrm{H}(15 \mathrm{~A})$ & 109.5 \\
\hline $\mathrm{C}(12)-\mathrm{C}(15)-\mathrm{H}(15 \mathrm{~B})$ & 109.5 \\
\hline $\mathrm{H}(15 \mathrm{~A})-\mathrm{C}(15)-\mathrm{H}(15 \mathrm{~B})$ & 109.5 \\
\hline $\mathrm{C}(12)-\mathrm{C}(15)-\mathrm{H}(15 \mathrm{C})$ & 109.5 \\
\hline $\mathrm{H}(15 \mathrm{~A})-\mathrm{C}(15)-\mathrm{H}(15 \mathrm{C})$ & 109.5 \\
\hline $\mathrm{H}(15 \mathrm{~B})-\mathrm{C}(15)-\mathrm{H}(15 \mathrm{C})$ & 109.5 \\
\hline $\mathrm{C}(13)-\mathrm{C}(16)-\mathrm{H}(16 \mathrm{~A})$ & 109.5 \\
\hline $\mathrm{C}(13)-\mathrm{C}(16)-\mathrm{H}(16 \mathrm{~B})$ & 109.5 \\
\hline $\mathrm{H}(16 \mathrm{~A})-\mathrm{C}(16)-\mathrm{H}(16 \mathrm{~B})$ & 109.5 \\
\hline $\mathrm{C}(13)-\mathrm{C}(16)-\mathrm{H}(16 \mathrm{C})$ & 109.5 \\
\hline $\mathrm{H}(16 \mathrm{~A})-\mathrm{C}(16)-\mathrm{H}(16 \mathrm{C})$ & 109.5 \\
\hline $\mathrm{H}(16 \mathrm{~B})-\mathrm{C}(16)-\mathrm{H}(16 \mathrm{C})$ & 109.5 \\
\hline
\end{tabular}


Vendola, Allais, Dechert Schmitt, Lee, Singer, and Morken Supplementary Information

\begin{tabular}{|c|c|}
\hline $\mathrm{C}(13)-\mathrm{C}(17)-\mathrm{H}(17 \mathrm{~A})$ & 109.5 \\
\hline $\mathrm{C}(13)-\mathrm{C}(17)-\mathrm{H}(17 \mathrm{~B})$ & 109.5 \\
\hline $\mathrm{H}(17 \mathrm{~A})-\mathrm{C}(17)-\mathrm{H}(17 \mathrm{~B})$ & 109.5 \\
\hline $\mathrm{C}(13)-\mathrm{C}(17)-\mathrm{H}(17 \mathrm{C})$ & 109.5 \\
\hline $\mathrm{H}(17 \mathrm{~A})-\mathrm{C}(17)-\mathrm{H}(17 \mathrm{C})$ & 109.5 \\
\hline $\mathrm{H}(17 \mathrm{~B})-\mathrm{C}(17)-\mathrm{H}(17 \mathrm{C})$ & 109.5 \\
\hline $\mathrm{B}(2)-\mathrm{O}(6)-\mathrm{C}(18)$ & $106.70(10)$ \\
\hline $\mathrm{B}(2)-\mathrm{O}(7)-\mathrm{C}(19)$ & $106.36(11)$ \\
\hline $\mathrm{O}(6)-\mathrm{C}(18)-\mathrm{C}(21)$ & $107.30(11)$ \\
\hline $\mathrm{O}(6)-\mathrm{C}(18)-\mathrm{C}(20)$ & $108.66(12)$ \\
\hline $\mathrm{C}(21)-\mathrm{C}(18)-\mathrm{C}(20)$ & $110.40(12)$ \\
\hline $\mathrm{O}(6)-\mathrm{C}(18)-\mathrm{C}(19)$ & $101.72(10)$ \\
\hline $\mathrm{C}(21)-\mathrm{C}(18)-\mathrm{C}(19)$ & $113.09(12)$ \\
\hline $\mathrm{C}(20)-\mathrm{C}(18)-\mathrm{C}(19)$ & $114.96(13)$ \\
\hline $\mathrm{O}(7)-\mathrm{C}(19)-\mathrm{C}(23)$ & $108.47(12)$ \\
\hline $\mathrm{O}(7)-\mathrm{C}(19)-\mathrm{C}(22)$ & $106.25(13)$ \\
\hline $\mathrm{C}(23)-\mathrm{C}(19)-\mathrm{C}(22)$ & $112.03(14)$ \\
\hline $\mathrm{O}(7)-\mathrm{C}(19)-\mathrm{C}(18)$ & $101.95(11)$ \\
\hline $\mathrm{C}(23)-\mathrm{C}(19)-\mathrm{C}(18)$ & $114.58(13)$ \\
\hline $\mathrm{C}(22)-\mathrm{C}(19)-\mathrm{C}(18)$ & $112.63(13)$ \\
\hline $\mathrm{C}(18)-\mathrm{C}(20)-\mathrm{H}(20 \mathrm{~A})$ & 109.5 \\
\hline $\mathrm{C}(18)-\mathrm{C}(20)-\mathrm{H}(20 \mathrm{~B})$ & 109.5 \\
\hline $\mathrm{H}(20 \mathrm{~A})-\mathrm{C}(20)-\mathrm{H}(20 \mathrm{~B})$ & 109.5 \\
\hline $\mathrm{C}(18)-\mathrm{C}(20)-\mathrm{H}(20 \mathrm{C})$ & 109.5 \\
\hline$H(20 A)-C(20)-H(20 C)$ & 109.5 \\
\hline $\mathrm{H}(20 \mathrm{~B})-\mathrm{C}(20)-\mathrm{H}(20 \mathrm{C})$ & 109.5 \\
\hline $\mathrm{C}(18)-\mathrm{C}(21)-\mathrm{H}(21 \mathrm{~A})$ & 109.5 \\
\hline $\mathrm{C}(18)-\mathrm{C}(21)-\mathrm{H}(21 \mathrm{~B})$ & 109.5 \\
\hline $\mathrm{H}(21 \mathrm{~A})-\mathrm{C}(21)-\mathrm{H}(21 \mathrm{~B})$ & 109.5 \\
\hline $\mathrm{C}(18)-\mathrm{C}(21)-\mathrm{H}(21 \mathrm{C})$ & 109.5 \\
\hline $\mathrm{H}(21 \mathrm{~A})-\mathrm{C}(21)-\mathrm{H}(21 \mathrm{C})$ & 109.5 \\
\hline $\mathrm{H}(21 \mathrm{~B})-\mathrm{C}(21)-\mathrm{H}(21 \mathrm{C})$ & 109.5 \\
\hline $\mathrm{C}(19)-\mathrm{C}(22)-\mathrm{H}(22 \mathrm{~A})$ & 109.5 \\
\hline $\mathrm{C}(19)-\mathrm{C}(22)-\mathrm{H}(22 \mathrm{~B})$ & 109.5 \\
\hline $\mathrm{H}(22 \mathrm{~A})-\mathrm{C}(22)-\mathrm{H}(22 \mathrm{~B})$ & 109.5 \\
\hline $\mathrm{C}(19)-\mathrm{C}(22)-\mathrm{H}(22 \mathrm{C})$ & 109.5 \\
\hline
\end{tabular}


Vendola, Allais, Dechert Schmitt, Lee, Singer, and Morken Supplementary Information

$\begin{array}{ll}\text { H(22A)-C(22)-H(22C) } & 109.5 \\ \text { H(22B)-C(22)-H(22C) } & 109.5 \\ \text { C(19)-C(23)-H(23A) } & 109.5 \\ \text { C(19)-C(23)-H(23B) } & 109.5 \\ \text { H(23A)-C(23)-H(23B) } & 109.5 \\ \text { C(19)-C(23)-H(23C) } & 109.5 \\ \text { H(23A)-C(23)-H(23C) } & 109.5 \\ \text { H(23B)-C(23)-H(23C) } & 109.5\end{array}$

Symmetry transformations used to generate equivalent atoms: 
Vendola, Allais, Dechert Schmitt, Lee, Singer, and Morken Supplementary Information

Table 4. Anisotropic displacement parameters $\left(\AA^{2} \times 10^{3}\right)$ for Compound $16(\mathrm{C} 23 \mathrm{H} 39 \mathrm{~B} 2 \mathrm{NO} 7)$. The anisotropic displacement factor exponent takes the form: $-2 \pi^{2}\left[h^{2} a^{* 2} U^{11}+\ldots+2 h k a^{*} b^{*} U^{12}\right]$

\begin{tabular}{|c|c|c|c|c|c|c|}
\hline & $\mathrm{U}^{11}$ & $\mathrm{U}^{22}$ & $\mathrm{U}^{33}$ & $U^{23}$ & $\mathrm{U}^{13}$ & $\mathrm{U}^{12}$ \\
\hline $\mathrm{O}(1)$ & $48(1)$ & $22(1)$ & $45(1)$ & $-4(1)$ & $22(1)$ & $0(1)$ \\
\hline $\mathrm{O}(2)$ & $42(1)$ & $28(1)$ & $60(1)$ & $-6(1)$ & $24(1)$ & $-7(1)$ \\
\hline $\mathrm{O}(3)$ & $31(1)$ & $32(1)$ & $58(1)$ & $1(1)$ & $19(1)$ & $1(1)$ \\
\hline $\mathrm{O}(4)$ & $56(1)$ & $22(1)$ & $36(1)$ & $1(1)$ & $9(1)$ & $0(1)$ \\
\hline $\mathrm{O}(5)$ & $63(1)$ & $24(1)$ & $35(1)$ & $-1(1)$ & $7(1)$ & $8(1)$ \\
\hline $\mathrm{N}(1)$ & $28(1)$ & $21(1)$ & $38(1)$ & $-1(1)$ & $12(1)$ & $2(1)$ \\
\hline $\mathrm{B}(1)$ & $27(1)$ & $24(1)$ & $34(1)$ & $0(1)$ & $3(1)$ & $0(1)$ \\
\hline $\mathrm{B}(2)$ & $25(1)$ & $24(1)$ & $28(1)$ & $-3(1)$ & $2(1)$ & $-2(1)$ \\
\hline $\mathrm{C}(1)$ & $41(1)$ & $24(1)$ & $39(1)$ & $-7(1)$ & $8(1)$ & $4(1)$ \\
\hline $\mathrm{C}(2)$ & $26(1)$ & $24(1)$ & $36(1)$ & $0(1)$ & $6(1)$ & $2(1)$ \\
\hline $\mathrm{C}(3)$ & $23(1)$ & $25(1)$ & $38(1)$ & 2(1) & $6(1)$ & 1(1) \\
\hline $\mathrm{C}(4)$ & $25(1)$ & $24(1)$ & $38(1)$ & $-3(1)$ & $4(1)$ & $-2(1)$ \\
\hline $\mathrm{C}(5)$ & $32(1)$ & $29(1)$ & $32(1)$ & $-1(1)$ & 2(1) & $5(1)$ \\
\hline$C(6)$ & $28(1)$ & $23(1)$ & $33(1)$ & $-1(1)$ & $12(1)$ & 2(1) \\
\hline $\mathrm{C}(7)$ & $27(1)$ & $24(1)$ & $28(1)$ & $-1(1)$ & $6(1)$ & $0(1)$ \\
\hline $\mathrm{C}(8)$ & $26(1)$ & $23(1)$ & $28(1)$ & $-4(1)$ & $5(1)$ & $-2(1)$ \\
\hline $\mathrm{C}(9)$ & $123(2)$ & $42(1)$ & $72(1)$ & $-11(1)$ & $59(1)$ & $7(1)$ \\
\hline $\mathrm{C}(10)$ & $52(1)$ & $29(1)$ & $54(1)$ & $-8(1)$ & $-10(1)$ & $7(1)$ \\
\hline $\mathrm{C}(11)$ & $54(1)$ & $62(1)$ & $73(1)$ & $-30(1)$ & $-25(1)$ & $18(1)$ \\
\hline$C(12)$ & $56(1)$ & $20(1)$ & $44(1)$ & $-1(1)$ & $4(1)$ & 2(1) \\
\hline $\mathrm{C}(13)$ & $57(1)$ & $24(1)$ & $43(1)$ & $-7(1)$ & $-4(1)$ & $6(1)$ \\
\hline $\mathrm{C}(14)$ & $104(2)$ & $28(1)$ & $89(2)$ & $4(1)$ & $31(1)$ & $-11(1)$ \\
\hline $\mathrm{C}(15)$ & $67(1)$ & $38(1)$ & $64(1)$ & $-3(1)$ & $-15(1)$ & $16(1)$ \\
\hline$C(16)$ & $69(1)$ & $52(1)$ & $93(2)$ & $-26(1)$ & $-31(1)$ & $9(1)$ \\
\hline $\mathrm{C}(17)$ & $98(2)$ & $38(1)$ & $51(1)$ & $-10(1)$ & $9(1)$ & $20(1)$ \\
\hline $\mathrm{O}(6)$ & $27(1)$ & $33(1)$ & $32(1)$ & $6(1)$ & $8(1)$ & $4(1)$ \\
\hline $\mathrm{O}(7)$ & $26(1)$ & $31(1)$ & $30(1)$ & $3(1)$ & $6(1)$ & $6(1)$ \\
\hline $\mathrm{C}(18)$ & $26(1)$ & $34(1)$ & $34(1)$ & $4(1)$ & $9(1)$ & $6(1)$ \\
\hline$C(19)$ & $30(1)$ & $36(1)$ & $32(1)$ & $2(1)$ & $10(1)$ & $9(1)$ \\
\hline $\mathrm{C}(20)$ & $38(1)$ & $38(1)$ & $52(2)$ & $6(1)$ & $10(1)$ & $16(1)$ \\
\hline $\mathrm{C}(21)$ & $28(1)$ & $50(1)$ & $42(1)$ & $2(1)$ & $3(1)$ & $0(1)$ \\
\hline & & & S-95 & & & \\
\hline
\end{tabular}


Vendola, Allais, Dechert Schmitt, Lee, Singer, and Morken Supplementary Information

\begin{tabular}{ccccccc}
$\mathrm{C}(22)$ & $57(1)$ & $57(1)$ & $38(1)$ & $-14(1)$ & $6(1)$ & $11(1)$ \\
$\mathrm{C}(23)$ & $34(1)$ & $59(1)$ & $41(1)$ & $14(1)$ & $15(1)$ & $8(1)$ \\
\hline
\end{tabular}


Vendola, Allais, Dechert Schmitt, Lee, Singer, and Morken Supplementary Information

Table 5. Hydrogen coordinates ( $\left.\times 10^{4}\right)$ and isotropic displacement parameters $\left(\AA^{2} \times 10^{3}\right)$ for Compound 16 (C23H39B2NO7).

\begin{tabular}{|c|c|c|c|c|}
\hline & $\mathrm{x}$ & $\mathrm{y}$ & $\mathrm{z}$ & $\mathrm{U}(\mathrm{eq})$ \\
\hline $\mathrm{H}(4)$ & 9328 & 6974 & 4711 & 35 \\
\hline $\mathrm{H}(5 \mathrm{~A})$ & 8951 & 5783 & 6092 & 37 \\
\hline $\mathrm{H}(5 \mathrm{~B})$ & 8117 & 6544 & 6021 & 37 \\
\hline $\mathrm{H}(6)$ & 7469 & 4987 & 5425 & 33 \\
\hline $\mathrm{H}(7)$ & 8005 & 6744 & 3112 & 32 \\
\hline $\mathrm{H}(8)$ & 6981 & 5704 & 3555 & 30 \\
\hline $\mathrm{H}(9 \mathrm{~A})$ & 9575 & 2520 & 1317 & 114 \\
\hline $\mathrm{H}(9 \mathrm{~B})$ & 9241 & 3565 & 1209 & 114 \\
\hline $\mathrm{H}(9 \mathrm{C})$ & 10144 & 3302 & 1997 & 114 \\
\hline $\mathrm{H}(10 \mathrm{~A})$ & 9351 & 1684 & 3107 & 69 \\
\hline $\mathrm{H}(10 \mathrm{~B})$ & 9997 & 2486 & 3644 & 69 \\
\hline $\mathrm{H}(10 \mathrm{C})$ & 8994 & 2280 & 4081 & 69 \\
\hline $\mathrm{H}(11 \mathrm{~A})$ & 7949 & 2061 & 1894 & 97 \\
\hline $\mathrm{H}(11 \mathrm{~B})$ & 7520 & 2667 & 2815 & 97 \\
\hline $\mathrm{H}(11 \mathrm{C})$ & 7678 & 3111 & 1658 & 97 \\
\hline $\mathrm{H}(14 \mathrm{~A})$ & 8023 & 10707 & 3803 & 109 \\
\hline $\mathrm{H}(14 \mathrm{~B})$ & 8829 & 9969 & 3645 & 109 \\
\hline $\mathrm{H}(14 \mathrm{C})$ & 8036 & 10158 & 2682 & 109 \\
\hline $\mathrm{H}(15 \mathrm{~A})$ & 6352 & 10149 & 3903 & 87 \\
\hline $\mathrm{H}(15 \mathrm{~B})$ & 6438 & 9605 & 2789 & 87 \\
\hline $\mathrm{H}(15 \mathrm{C})$ & 6152 & 9070 & 3845 & 87 \\
\hline $\mathrm{H}(16 \mathrm{~A})$ & 8926 & 9964 & 5548 & 110 \\
\hline $\mathrm{H}(16 \mathrm{~B})$ & 8881 & 9072 & 6297 & 110 \\
\hline $\mathrm{H}(16 \mathrm{C})$ & 9188 & 8980 & 5083 & 110 \\
\hline $\mathrm{H}(17 \mathrm{~A})$ & 7215 & 10295 & 5856 & 93 \\
\hline $\mathrm{H}(17 \mathrm{~B})$ & 6460 & 9493 & 5626 & 93 \\
\hline $\mathrm{H}(17 \mathrm{C})$ & 7245 & 9407 & 6620 & 93 \\
\hline $\mathrm{H}(20 \mathrm{~A})$ & 3846 & 8009 & 5142 & 64 \\
\hline $\mathrm{H}(20 \mathrm{~B})$ & 4883 & 8425 & 5173 & 64 \\
\hline $\mathrm{H}(20 \mathrm{C})$ & 4307 & 8226 & 4031 & 64 \\
\hline
\end{tabular}


Vendola, Allais, Dechert Schmitt, Lee, Singer, and Morken Supplementary Information

\begin{tabular}{|c|c|c|c|c|}
\hline $\mathrm{H}(21 \mathrm{~A})$ & 3572 & 6372 & 4474 & 60 \\
\hline $\mathrm{H}(21 \mathrm{~B})$ & 4053 & 6630 & 3388 & 60 \\
\hline $\mathrm{H}(21 \mathrm{C})$ & 4445 & 5787 & 4120 & 60 \\
\hline $\mathrm{H}(22 \mathrm{~A})$ & 5084 & 7816 & 6878 & 76 \\
\hline $\mathrm{H}(22 \mathrm{~B})$ & 5881 & 7118 & 7344 & 76 \\
\hline $\mathrm{H}(22 \mathrm{C})$ & 6056 & 7756 & 6324 & 76 \\
\hline $\mathrm{H}(23 \mathrm{~A})$ & 3932 & 6458 & 6614 & 66 \\
\hline $\mathrm{H}(23 \mathrm{~B})$ & 4244 & 5589 & 5937 & 66 \\
\hline $\mathrm{H}(23 \mathrm{C})$ & 4757 & 5803 & 7109 & 66 \\
\hline $\mathrm{H}(20 \mathrm{D})$ & 3906 & 8053 & 5243 & 61 \\
\hline $\mathrm{H}(20 \mathrm{E})$ & 4641 & 8632 & 4609 & 61 \\
\hline $\mathrm{H}(20 \mathrm{~F})$ & 4229 & 7689 & 4108 & 61 \\
\hline $\mathrm{H}(21 \mathrm{D})$ & 3598 & 6766 & 4193 & 43 \\
\hline $\mathrm{H}(21 \mathrm{E})$ & 4496 & 6622 & 3517 & 43 \\
\hline $\mathrm{H}(21 \mathrm{~F})$ & 3996 & 5756 & 4018 & 43 \\
\hline $\mathrm{H}(22 \mathrm{D})$ & 5042 & 7447 & 7117 & 83 \\
\hline $\mathrm{H}(22 \mathrm{E})$ & 5897 & 6812 & 6819 & 83 \\
\hline $\mathrm{H}(22 \mathrm{~F})$ & 6026 & 7901 & 6890 & 83 \\
\hline $\mathrm{H}(23 \mathrm{D})$ & 3885 & 6395 & 6590 & 51 \\
\hline $\mathrm{H}(23 \mathrm{E})$ & 4339 & 5419 & 6353 & 51 \\
\hline $\mathrm{H}(23 \mathrm{~F})$ & 4939 & 6172 & 7047 & 51 \\
\hline
\end{tabular}


Vendola, Allais, Dechert Schmitt, Lee, Singer, and Morken Supplementary Information

Table 6. Torsion angles $\left[{ }^{\circ}\right]$ for Compound 16 (C23H39B2NO7).

\begin{tabular}{|c|c|}
\hline $\mathrm{C}(12)-\mathrm{O}(4)-\mathrm{B}(1)-\mathrm{O}(5)$ & $-7.06(17)$ \\
\hline $\mathrm{C}(12)-\mathrm{O}(4)-\mathrm{B}(1)-\mathrm{C}(7)$ & $178.93(13)$ \\
\hline $\mathrm{C}(13)-\mathrm{O}(5)-\mathrm{B}(1)-\mathrm{O}(4)$ & $-11.68(17)$ \\
\hline $\mathrm{C}(13)-\mathrm{O}(5)-\mathrm{B}(1)-\mathrm{C}(7)$ & $162.14(13)$ \\
\hline $\mathrm{C}(2)-\mathrm{O}(1)-\mathrm{C}(1)-\mathrm{C}(10)$ & $-67.31(17)$ \\
\hline $\mathrm{C}(2)-\mathrm{O}(1)-\mathrm{C}(1)-\mathrm{C}(9)$ & $175.81(16)$ \\
\hline $\mathrm{C}(2)-\mathrm{O}(1)-\mathrm{C}(1)-\mathrm{C}(11)$ & $57.52(18)$ \\
\hline $\mathrm{C}(1)-\mathrm{O}(1)-\mathrm{C}(2)-\mathrm{O}(2)$ & $-1.8(2)$ \\
\hline $\mathrm{C}(1)-\mathrm{O}(1)-\mathrm{C}(2)-\mathrm{N}(1)$ & $179.02(11)$ \\
\hline $\mathrm{C}(3)-\mathrm{N}(1)-\mathrm{C}(2)-\mathrm{O}(2)$ & $169.74(14)$ \\
\hline $\mathrm{C}(6)-\mathrm{N}(1)-\mathrm{C}(2)-\mathrm{O}(2)$ & $-15.6(2)$ \\
\hline $\mathrm{C}(3)-\mathrm{N}(1)-\mathrm{C}(2)-\mathrm{O}(1)$ & $-11.0(2)$ \\
\hline $\mathrm{C}(6)-\mathrm{N}(1)-\mathrm{C}(2)-\mathrm{O}(1)$ & $163.70(12)$ \\
\hline $\mathrm{C}(2)-\mathrm{N}(1)-\mathrm{C}(3)-\mathrm{O}(3)$ & $-3.7(2)$ \\
\hline $\mathrm{C}(6)-\mathrm{N}(1)-\mathrm{C}(3)-\mathrm{O}(3)$ & $-178.98(14)$ \\
\hline $\mathrm{C}(2)-\mathrm{N}(1)-\mathrm{C}(3)-\mathrm{C}(4)$ & $175.04(13)$ \\
\hline $\mathrm{C}(6)-\mathrm{N}(1)-\mathrm{C}(3)-\mathrm{C}(4)$ & $-0.22(14)$ \\
\hline $\mathrm{O}(3)-\mathrm{C}(3)-\mathrm{C}(4)-\mathrm{C}(5)$ & $-146.59(15)$ \\
\hline $\mathrm{N}(1)-\mathrm{C}(3)-\mathrm{C}(4)-\mathrm{C}(5)$ & $34.66(13)$ \\
\hline $\mathrm{O}(3)-\mathrm{C}(3)-\mathrm{C}(4)-\mathrm{C}(7)$ & 106.73(16) \\
\hline $\mathrm{N}(1)-\mathrm{C}(3)-\mathrm{C}(4)-\mathrm{C}(7)$ & $-72.02(12)$ \\
\hline $\mathrm{C}(3)-\mathrm{C}(4)-\mathrm{C}(5)-\mathrm{C}(6)$ & $-53.01(11)$ \\
\hline $\mathrm{C}(7)-\mathrm{C}(4)-\mathrm{C}(5)-\mathrm{C}(6)$ & $55.90(11)$ \\
\hline $\mathrm{C}(2)-\mathrm{N}(1)-\mathrm{C}(6)-\mathrm{C}(5)$ & $149.89(12)$ \\
\hline $\mathrm{C}(3)-\mathrm{N}(1)-\mathrm{C}(6)-\mathrm{C}(5)$ & $-34.38(13)$ \\
\hline $\mathrm{C}(2)-\mathrm{N}(1)-\mathrm{C}(6)-\mathrm{C}(8)$ & $-103.17(13)$ \\
\hline $\mathrm{C}(3)-\mathrm{N}(1)-\mathrm{C}(6)-\mathrm{C}(8)$ & $72.57(13)$ \\
\hline $\mathrm{C}(4)-\mathrm{C}(5)-\mathrm{C}(6)-\mathrm{N}(1)$ & $52.00(11)$ \\
\hline$C(4)-C(5)-C(6)-C(8)$ & $-58.55(11)$ \\
\hline $\mathrm{O}(4)-\mathrm{B}(1)-\mathrm{C}(7)-\mathrm{C}(4)$ & $113.29(14)$ \\
\hline $\mathrm{O}(5)-\mathrm{B}(1)-\mathrm{C}(7)-\mathrm{C}(4)$ & $-60.04(17)$ \\
\hline $\mathrm{O}(4)-\mathrm{B}(1)-\mathrm{C}(7)-\mathrm{C}(8)$ & $-131.09(14)$ \\
\hline $\mathrm{O}(5)-\mathrm{B}(1)-\mathrm{C}(7)-\mathrm{C}(8)$ & $55.57(19)$ \\
\hline$C(3)-C(4)-C(7)-B(1)$ & $-160.81(11)$ \\
\hline
\end{tabular}


Vendola, Allais, Dechert Schmitt, Lee, Singer, and Morken Supplementary Information

\begin{tabular}{|c|c|}
\hline $\mathrm{C}(5)-\mathrm{C}(4)-\mathrm{C}(7)-\mathrm{B}(1)$ & $93.19(12)$ \\
\hline $\mathrm{C}(3)-\mathrm{C}(4)-\mathrm{C}(7)-\mathrm{C}(8)$ & $72.52(12)$ \\
\hline $\mathrm{C}(5)-\mathrm{C}(4)-\mathrm{C}(7)-\mathrm{C}(8)$ & $-33.49(12)$ \\
\hline $\mathrm{N}(1)-\mathrm{C}(6)-\mathrm{C}(8)-\mathrm{B}(2)$ & $166.73(10)$ \\
\hline $\mathrm{C}(5)-\mathrm{C}(6)-\mathrm{C}(8)-\mathrm{B}(2)$ & $-87.83(12)$ \\
\hline $\mathrm{N}(1)-\mathrm{C}(6)-\mathrm{C}(8)-\mathrm{C}(7)$ & $-66.51(12)$ \\
\hline $\mathrm{C}(5)-\mathrm{C}(6)-\mathrm{C}(8)-\mathrm{C}(7)$ & $38.93(12)$ \\
\hline $\mathrm{O}(6)-\mathrm{B}(2)-\mathrm{C}(8)-\mathrm{C}(6)$ & $172.69(12)$ \\
\hline $\mathrm{O}(7)-\mathrm{B}(2)-\mathrm{C}(8)-\mathrm{C}(6)$ & $-12.13(19)$ \\
\hline $\mathrm{O}(6)-\mathrm{B}(2)-\mathrm{C}(8)-\mathrm{C}(7)$ & $53.72(17)$ \\
\hline $\mathrm{O}(7)-\mathrm{B}(2)-\mathrm{C}(8)-\mathrm{C}(7)$ & $-131.11(14)$ \\
\hline $\mathrm{B}(1)-\mathrm{C}(7)-\mathrm{C}(8)-\mathrm{C}(6)$ & $-122.10(12)$ \\
\hline$C(4)-C(7)-C(8)-C(6)$ & $-2.97(12)$ \\
\hline $\mathrm{B}(1)-\mathrm{C}(7)-\mathrm{C}(8)-\mathrm{B}(2)$ & $3.80(17)$ \\
\hline $\mathrm{C}(4)-\mathrm{C}(7)-\mathrm{C}(8)-\mathrm{B}(2)$ & $122.94(12)$ \\
\hline $\mathrm{B}(1)-\mathrm{O}(4)-\mathrm{C}(12)-\mathrm{C}(14)$ & $143.99(16)$ \\
\hline $\mathrm{B}(1)-\mathrm{O}(4)-\mathrm{C}(12)-\mathrm{C}(15)$ & $-97.53(15)$ \\
\hline $\mathrm{B}(1)-\mathrm{O}(4)-\mathrm{C}(12)-\mathrm{C}(13)$ & $21.24(16)$ \\
\hline $\mathrm{B}(1)-\mathrm{O}(5)-\mathrm{C}(13)-\mathrm{C}(17)$ & $146.17(14)$ \\
\hline $\mathrm{B}(1)-\mathrm{O}(5)-\mathrm{C}(13)-\mathrm{C}(16)$ & $-94.89(16)$ \\
\hline $\mathrm{B}(1)-\mathrm{O}(5)-\mathrm{C}(13)-\mathrm{C}(12)$ & $23.84(16)$ \\
\hline $\mathrm{O}(4)-\mathrm{C}(12)-\mathrm{C}(13)-\mathrm{O}(5)$ & $-26.94(15)$ \\
\hline $\mathrm{C}(14)-\mathrm{C}(12)-\mathrm{C}(13)-\mathrm{O}(5)$ & $-144.70(15)$ \\
\hline $\mathrm{C}(15)-\mathrm{C}(12)-\mathrm{C}(13)-\mathrm{O}(5)$ & $87.03(15)$ \\
\hline $\mathrm{O}(4)-\mathrm{C}(12)-\mathrm{C}(13)-\mathrm{C}(17)$ & $-144.91(15)$ \\
\hline $\mathrm{C}(14)-\mathrm{C}(12)-\mathrm{C}(13)-\mathrm{C}(17)$ & $97.3(2)$ \\
\hline $\mathrm{C}(15)-\mathrm{C}(12)-\mathrm{C}(13)-\mathrm{C}(17)$ & $-30.9(2)$ \\
\hline $\mathrm{O}(4)-\mathrm{C}(12)-\mathrm{C}(13)-\mathrm{C}(16)$ & $86.51(15)$ \\
\hline $\mathrm{C}(14)-\mathrm{C}(12)-\mathrm{C}(13)-\mathrm{C}(16)$ & $-31.2(2)$ \\
\hline $\mathrm{C}(15)-\mathrm{C}(12)-\mathrm{C}(13)-\mathrm{C}(16)$ & $-159.51(14)$ \\
\hline $\mathrm{O}(7)-\mathrm{B}(2)-\mathrm{O}(6)-\mathrm{C}(18)$ & $-10.73(16)$ \\
\hline $\mathrm{C}(8)-\mathrm{B}(2)-\mathrm{O}(6)-\mathrm{C}(18)$ & $164.89(12)$ \\
\hline $\mathrm{O}(6)-\mathrm{B}(2)-\mathrm{O}(7)-\mathrm{C}(19)$ & $-10.26(16)$ \\
\hline $\mathrm{C}(8)-\mathrm{B}(2)-\mathrm{O}(7)-\mathrm{C}(19)$ & $174.17(12)$ \\
\hline $\mathrm{B}(2)-\mathrm{O}(6)-\mathrm{C}(18)-\mathrm{C}(21)$ & $-93.51(13)$ \\
\hline $\mathrm{B}(2)-\mathrm{O}(6)-\mathrm{C}(18)-\mathrm{C}(20)$ & $147.11(13)$ \\
\hline
\end{tabular}


Vendola, Allais, Dechert Schmitt, Lee, Singer, and Morken Supplementary Information

$$
\begin{array}{lr}
\mathrm{B}(2)-\mathrm{O}(6)-\mathrm{C}(18)-\mathrm{C}(19) & 25.45(14) \\
\mathrm{B}(2)-\mathrm{O}(7)-\mathrm{C}(19)-\mathrm{C}(23) & 146.45(13) \\
\mathrm{B}(2)-\mathrm{O}(7)-\mathrm{C}(19)-\mathrm{C}(22) & -92.93(14) \\
\mathrm{B}(2)-\mathrm{O}(7)-\mathrm{C}(19)-\mathrm{C}(18) & 25.19(15) \\
\mathrm{O}(6)-\mathrm{C}(18)-\mathrm{C}(19)-\mathrm{O}(7) & -30.41(14) \\
\mathrm{C}(21)-\mathrm{C}(18)-\mathrm{C}(19)-\mathrm{O}(7) & 84.34(14) \\
\mathrm{C}(20)-\mathrm{C}(18)-\mathrm{C}(19)-\mathrm{O}(7) & -147.60(12) \\
\mathrm{O}(6)-\mathrm{C}(18)-\mathrm{C}(19)-\mathrm{C}(23) & -147.34(13) \\
\mathrm{C}(21)-\mathrm{C}(18)-\mathrm{C}(19)-\mathrm{C}(23) & -32.59(17) \\
\mathrm{C}(20)-\mathrm{C}(18)-\mathrm{C}(19)-\mathrm{C}(23) & 95.47(16) \\
\mathrm{O}(6)-\mathrm{C}(18)-\mathrm{C}(19)-\mathrm{C}(22) & 83.05(14) \\
\mathrm{C}(21)-\mathrm{C}(18)-\mathrm{C}(19)-\mathrm{C}(22) & -162.19(13) \\
\mathrm{C}(20)-\mathrm{C}(18)-\mathrm{C}(19)-\mathrm{C}(22) & -34.14(17)
\end{array}
$$

Symmetry transformations used to generate equivalent atoms:

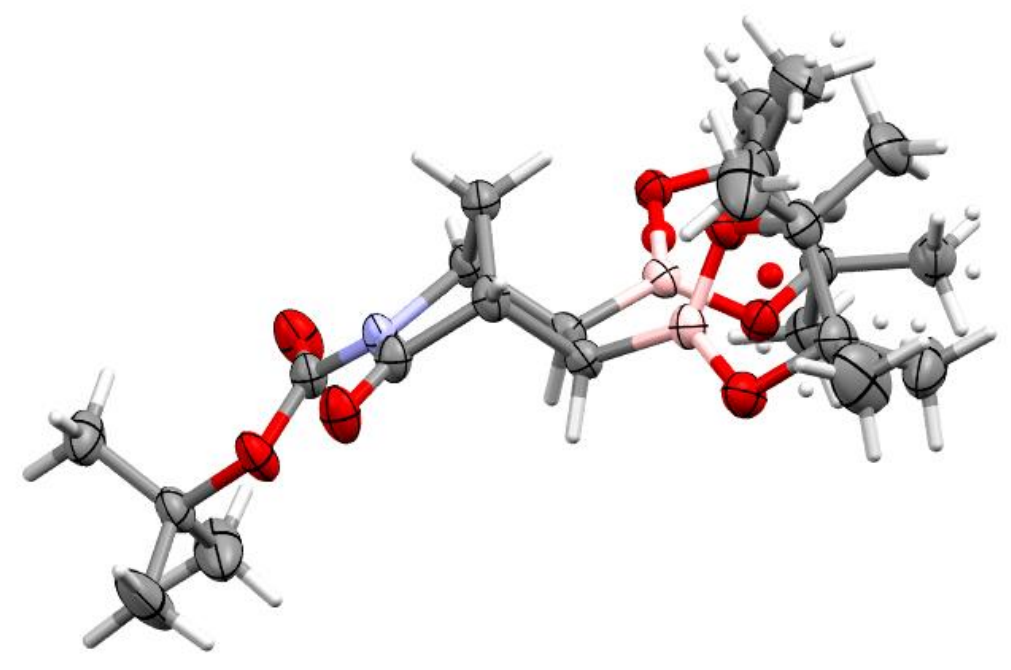

Figure 1: 3-D Ortep figure of Compound $16\left(\mathrm{C}_{23} \mathrm{H}_{39} \mathrm{~B}_{2} \mathrm{NO}_{7}\right)(50 \%$ ellipsoid contour probability level) 